\title{
A STUDY OF THE GENUS LATHYRUS
}

¿B 413

S9 B5

apy 1

The Genus Lathyrus

The Sweet Pea in Botany and Horticulture

Classification of Garden Varieties of the Sweet Pea

Winter Flowering Sweet Peas

\section{A THESIS}

Presented to the Faculty of the Graduate School OF CORNeLl UNIVERSity FOR THE DEGREE OF DOCTOR OF PHILOSOPHY

$\mathrm{BY}$

ALVIN CASEY BEAL, B.S., M.S.A.

[Published as Bulletins 319, 320 and 342 of the Agricultural Experiment Station of the College of Agriculture of Cornell University.] 



\title{
A STUDY OF THE GENUS LATHYRUS
}

\author{
The Genus Lathyrus \\ The Sweet Pea in Botany and Horticulture \\ Classification of Garden Varieties of the Sweet Pea \\ Winter Flowering Sweet Peas
}

\begin{abstract}
A THESIS
Presented to the Faculty of the Graduate School of Cornfid, University for the Degree of DOC'TOR OF PHILOSOPHY
\end{abstract}

ALVIN CASEY BEAL, B.S., M.S.A. of the College of Agriculture of Cornell University.] 
Sornal inveranty Shbory 



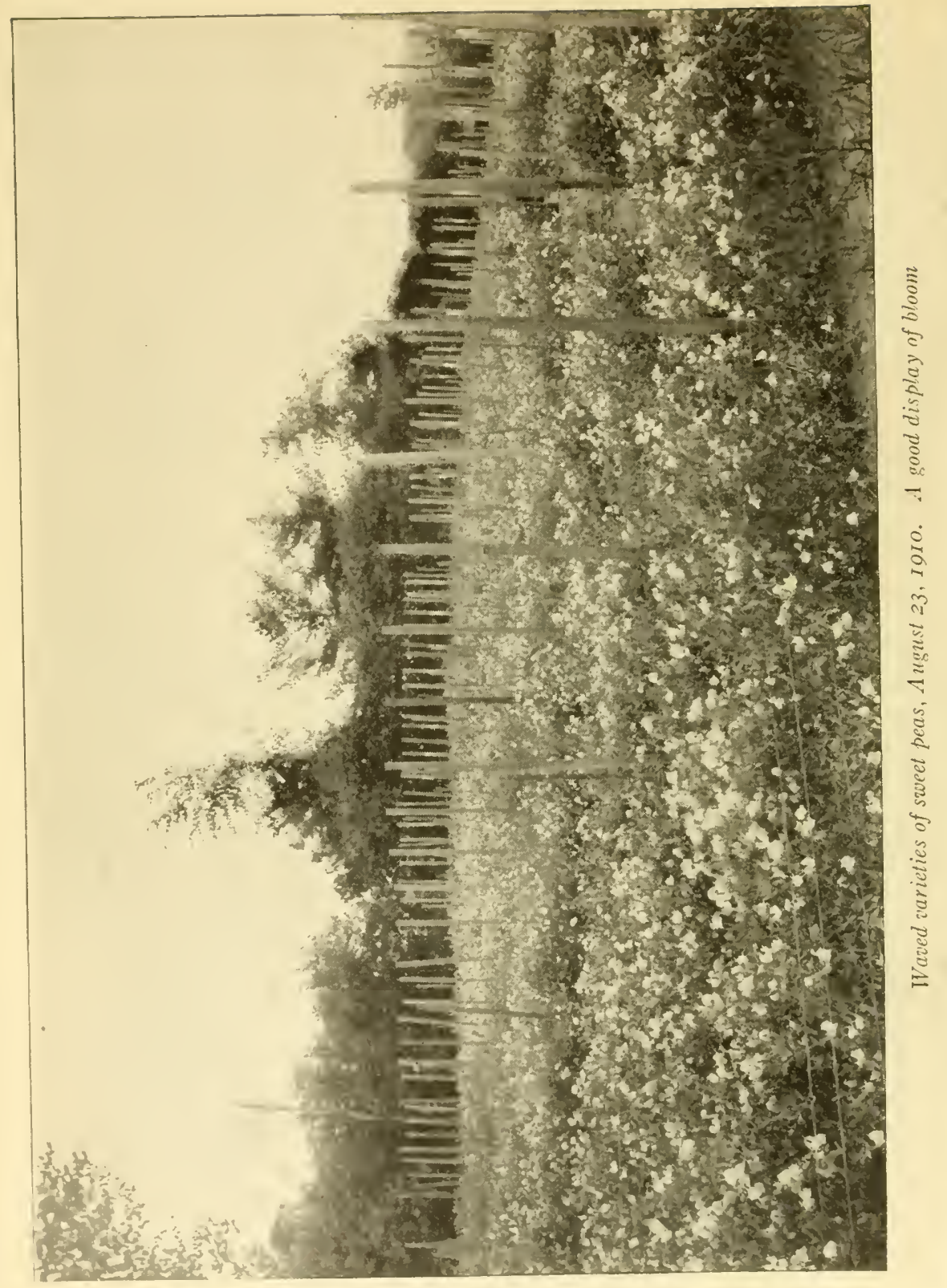




\section{PREFACE}

This study was begun in the autumn of I909. It has been carried on continuously under glass during two winters, and outdoors in the summer of igio. A collection of the obtainable species of Lathyrus, as well as a very extensive collection of the varieties of sweet peas, was grown at Ithaca. In addition to the above the writer was enabled to study the exhibits of outdoor-grown sweet peas at the annual exhibition of the National Sweet Pea Society at New York in July, I9Io, and of the winterflowering varicties at Boston in March, I9II.

The investigation was begun with a view of studying the various species of Lathyrus for the purpose of monographing them, and particularly of determining their value as ornamental plants. The studies on sweet peas included the evolution of the flower, as well as the preparation of careful descriptions and the detection and elimination of synonyms among present-day varieties. The descriptions of the garden varieties will appear in a later publication; those of winter-flowering varieties are included in Bulletin 3 I 9 of this station.

The author wishes to extend his thanks and grateful acknowledgments to Professor John Craig, who has given great encouragement, kindly advice, and all possible facilities for carrying on the investigation; to the National Sweet Pea Society for their cooperation in the variety tests; to the United States Department of Agriculture for seeds of species of Lathyrus; and to the seedsmen of the United States and Great Britain who contributed seeds for the trials. Among the latter, mention should be made of the assistance rendered by Messrs. C. C. Morse \& Co. in contributing a collection of seventy-two varieties, representing various types and old or obsolete varieties, for the study on the evolution of the sweet pea. 


\section{CONTENTS}

Part I. The genus Lathyrus. . . . . . . . . . . . . . . . . . 66

Botany of the genus. ........................ 66 I

Artificial key to the species of Lathyrus .............. 663

Descriptions of the species.................. 667

History of the cultivated lathyrus. . . . . . . . . . . 673

Descriptions of cultivated species................ 674

Part II. The sweet pea in botany and in horticulture.......... $\sigma_{7} 8$

History of the sweet pea ....................... 678

Botanical history........................... 678

British horticultural history ................. $6 S_{4}$

American horticultural history . . . . . . . . . . . 691

Evolution. . . . . . . . . . . . . . . . . . . . . . . . 693

Pollination. . . . . . . . . . . . . . . . . . . . . . . 605

Dwarf sweet peas................................. 697

Varicties of cupid sweet peas...................6gs

Unpopularity of the type. . . . . . . . . . . . . . . . . 699

Garden culture of the sweet pea................. 700

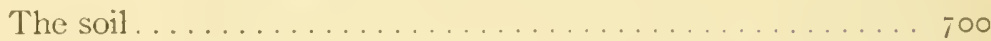

The seed........................... 70 I

Planting. . . . . . . . . . . . . . . . . .

Supports........................... 706

Cultivation. . . . . . . . . . . . . . 709

Summary............................ 710

Insects and diseases . . . . . . . . . . . . . . .

Insects............................ 710

Diseases............................

Exhibiting sweet peas..................... 


\title{
SWEET PEA STUDIES - III \\ CULTURE OF THE SWEET PEA
}

\author{
Alvin C. Beal \\ PART I. THE GENUS LATHYRUS \\ BOTANY OF THE GENUS
}

The genus Lathyrus (a name used by Theophrastus for some leguminous plant) belongs to the important family Leguminosae, which embraces three suborders, eighteen tribes, and one hundred and twenty-seven genera of plants cultivated in North America. The suborder Papilioneae is distinguished from the suborder Mimoseae in having irregular or zygomorphic flowers, and from the suborder Caesalpineae in having papilionaceous flowers - that is, the standard outside the other petals, and enclosing them in the bud.

Among the most important genera that contain ornamental plants are Thermopsis, Lupinus, Laburnum, Genista, Cytisus, Cladrastis, Hedysarum, Lespedeza, Lotus, Dolichos, Pueraria, Erythrina, Apios, Centrosema, Wisteria, Robinia, Clianthus, Swainsona, Caragana, and Glycyrrhiza. Then there are the genera of economic importance, Arachis, Onobrychis, Desmodium, Vicia, Pisum, Lens, Phaseolus, Vigna, Mucuna, Glycine, Trifolium, Medicago, Melilotus, and Indigofera.

The plants of the tribe Vicia, which includes the genera Abrus, Lens, Vicia, Pisum, and Lathyrus, are typically climbing herbs, with evenly pinnate leaves, which raise themselves by means of tendrils at the tips of the petioles. The varieties of Phaseolus, the other tribe of typically climbing herbaceous plants, have twining stems and three leaflets.

Abrus differs from the other genera of this tribe in having woody stems, and nine stamens instead of ten. Lens (lentil) has flowers with the wings adherent to the keel. Vicia (vetch), Pisum (pea), and Lathyrus are closely allied and somewhat difficult to distinguish. Vicia is usually known by the sheath of the stamens being oblique at the mouth, and the style being slender and bearded at the apex or only around the upper part; Pisum and Lathyrus have the stamen sheath even at the mouth, but are distinct from each other in that in Pisum the calyx lobes are leafy 
and the style is flattened laterally and bearded down the inner edge, while in Lathyrus the style is flattened on the back and front and is bearded down one face.

The flowers of Lathyrus are solitary or racemose, on long, axillary peduncles. The calyx is oblique, campanulate, five-parted, the teeth nearly equal or the upper two shorter than the lower. The corolla consists of five parts. The upper, or odd, petal, known as the vexillum, or standard, is larger than the others and encloses them in the bud. There is a notch at the apex and ordinarily a short claw. The form is broadly obovate or roundish and the petal is usually turned backward or spreading. The colors are dark blue or purple, riolet, rose, white, or yellow. The two lateral petals, or wings, are falcate, obovate, or oblong, oblique and exterior to the lower two, which are shorter, incurved, connivent, and more or less coherent along their anterior edge, forming the keel, or carina. The keel encloses the stamens and pistil.

The stamens are diadelphous (9 and I), or monodelphous below. The style is curved, sometimes twisted, flattened, hairy along the inner side (next the free stamen); orary sessile, or stalked with numerous ovules, becoming a one-celled pod. This is flat or terete, dehiscent, iwo-valved, continuous between seeds.

The seeds are globose or angular, with a hard, smooth testa. The radicle is curved inward. The cotyledons are accumbent.

The plants are herbaceous vines, rarely erect herbs, with pinnate, mostly tendril-bearing leaves. The old genus Orobus, which originally was created to include all the erect forms without tendrils, has since been included in the genus Lathyrus by Bentham and Hooker and by later botanists.

Species of Lathyrus are found in Europe, Asia, northern Africa, Sicily, and North and South America.

The genus is generally divided into two sections:

I. Eulathyrus (from $c u$, well, and lathyrus; genuine species). Texillum toothless at the base. Leaves opposite or wanting. Petioles narrow-winged.

2. Clymenum (clymenos, clear). Vexillum furnished with a conical gibbosity on each side at the base. Lower petioles leafless; upper ones bearing two to six usually alternate leaflets. Petioles usually winged.

Horticulturally the species may be divided into perennial and annual species. The following classification of the species is based in part on the artificial key to the American species, published by Theodore G. White in the Bulletin of the Torrey Botanical Club, Vol. XXI, iS94: 
Artificial key to the species of Lathyrus

I. Habit climbing, leaves tendril-bearing.

A. Eulathyrus.

B. Annuals.

C. Petioles leafless.

L. aphaca L.

L. Nissolia L.

CC. Leaflets one pair.

D. Stems wingless.

L. pusillus Ell.

L. subulatus Lam.

L. inconspicunts L.

L. sphaericus Retz.

L. micranthus Gerard.

L. angulatus $\mathrm{L}$.

L. leptophyllus Bieb.

L. setifolius L.

L. hirtus Lam.

DD. Stems winged.

L. sativus $\mathrm{L}$.

L. cicera $\mathrm{L}$.

L. hirsutus L.

L. annuus $\mathrm{L}$.

L. odoratus L.

L. Tingitanus L.

CCC. Leaflets 2-3 pairs.

L. clymenoides DC.

L. cirrhosus DC.

L. turgidus Lam.

L. purpureus Presl.

L. ciliatus Guss.

BB. Perennials.

C. Leaflets one pair.

D. Stipules narrow.

E. Stems wingless.

L. pratensis L.

L. tuberosus L.

L. sessilifolius Tenore.

L. roseus Stev.

L. tomentosus Lam.

L. sericeus Lam. 
I. Habit climbing, leaves tendril-bearing - (Continucd). EE. Stems winged.

L. sylvestris L.

L. pubesccns IIook.

L. grandiflorus Sims.

L. rotundifolius Willd.

L. undulatus Boiss.

DD. Stipules broad.

E. Stems wingless.

L. Magcllanicus Lam.

L. nervosus Lam.

EL. Stems winged.

L. latifolitus L.

CC. Leaflets more than one pair.

D. Stems winged.

L. palustris L.

L. Watsoni White.

L. Jepsoni Greene.

L. heterophyllus L.

DD. Stems wingless.

E. Plant glabrous.

F. Stipules large.

G. Leaflets 2-5 (mostly 3) pairs.

L. ochrolencus Hook.

L. myrtifolins Muhl.

L. panciflorus Fernald.

L. parviflorus S. W'atson.

L. pisiformis $\mathrm{L}$.

L. Bolanderii S. Watson.

GG. Leaflets $5>$ pairs.

L. sulphureus Brew.

L. Alefeldii White.

L. polyphyllus Nutt.

L. maritimus Bigel.

L. vestitus Nutt.

FF. Stipules narrow.

L. lactiflorus Greene.

I. splendens Kellogg.

L. decaphyllus Pursh.

L. violaieus Greene.

L. coriacous White. 
I. Habit climbing, leaves tendril-bearing-(Continued).

FF. Stipules narrow-(Continued).
L. venosus Muhl.
L. longipes White.
L. graminifolius White.
L. Macraei Hook.

EE. Plant densely silky villous all over.

L. litoralis.

AA. Clymenum.
L. diffusus.
L. clymemun $\mathrm{L}$.
L. articulatus L.

II. Plant erect or nearly so, tendrils wanting or much reduced. (Orobus.)

A. Peduncles 2-several-flowered.

B. Flowers white or yellowish.

L. montanus Bernh.

L. Arizonicus Britton.

L. Cusickii S. Watson.

L. obovatus Torr.

L. rigidus White.

BB. Flowers purple.

C. Leaflets $5^{-7}$ pairs.

L. ornatus Nutt.

L. Nuttallii S. Watson.

L. niger Bernh.

L. Oregonensis White.

L. vernus Bernh.

CC. Leaflets $I-2$ pairs.

L. bijugatus White.

AA. Peduncles I-flowered.

L. Torreyi A. Gray.

Previous to White's monograph only two attempts had been made to enumerate the species of the genus. The first was by Alefield (Bonplandia, June, I860), who placed all the American species in the genus Orobus; the second attempt was by Watson (Amer. Jour. Sci., Feb., I 876 ). who enumerated thirteen species.*

*. Mention should be made of the more recent monographs on the genus Lathyrus, namely:

Über einige Orobus-Arten und ihre geographische Verbreitung. Series I Lutei. Ein Beitrag zur Systematik der Viceen. Von Dr. Karl Fritsch. Sitzber. K. Akad. Wiss. (Vienna), Math. Naturw. K1. CIV Band ( 1895 ).

Über einige Lathyrus-Arten aus der Section Eulathyrus und ihre geographische Verbreitung. August Ginzberger. Sitzber. K. Akad. Wiss. (Vienna), Math. Naturw. K1. CV Band (I896), pp. 28 I353 , plates and maps. 
Some one hundred and thirty other species, which are considered good by the Index Kewensis but not included in the writer's classification, are as follows:

Acutus, Alberjilla, albus, Algeridus, Allardii, alpestris, altaicus, amoenus, aphyllus, Armonens, asphodeloides, astrophia, aurantius, bijugus, blepharicarpus, brachydon, brachypterus, Brownii, campestris, canescens, cassius, chloranthus, cicerella, cicerula, cinctus, coerulescens, colchicus, crassipes, cryophilus, cyaneus, Davidii, debilis, dicirrhus, dielsianus, Dinklagei, diversifolius, Drummondii, dumetorum, ecirhosus, elegans, Enodi, Engelmanni, cpetiolaris, erectus, Ewaldii, filiformis, fissus, fruitescens, Goldsteinae, Gorgoni, gracilis, gracillimus, Graphiosa, helodcs, hierosolymitanus, hygrophyllus, incurvus, intricatus, italicus, kilanandscharicus, laetifolius, laerigatus, lanceolatus, lancifolius, Lay'ardii, Ledebounii, leucanthus, Libani, linearifolius, lusitanicus, lutcus, ly'cins, macrorrhizus, magniflorus, malosanus, marmoratus, Messerschmidtii, Mexicanus, microplyllus, miniatus, mollis, Mulkak, multiceps, multiflorus, mutabilus, nervatus, neurolobus, nitens, Numidicus, occidentalis, ochraceus, ovalifolius, pallesccns, pannonicus, parisiensis, Parreiszii, pentaplyyllus, pisaster, platystylis, polyanthos, psendo-aphaca, pterocaulos, puberulus, purpurco-coeruleus, quadrimarginatus, Sanbergii, Schmiperii, setiger, Shaffneri, sinensis, spathulatus, spatulima, speciosus, spectabilis, stenobolus, stenophyllus, stipularis, strictus, subandinus, subrotundus, Szowitsii, Tanakce, tetrapterus, trachycarpus, trachyspermus, trichocalyx, Utahensis, variabilis, varius, venetus, villosus, vincalis, and Tolckmanni.

The Encyclopedia of American Horticulture describes sixteen species in the American trade. These are: odoratus, Tingitanus, grandiflorus, syliestris, rotundifolius, undulatus, latifolius, Magellanicus, palustris, maritimus, venosus, splendens, montanus, polymorpluts, niger, and vermus.

The writer has been unable to find maritimus, undulatus, palustris, splendens, montanus, rotundifolius, polymorphus, grandiflorus, and venosus in the present-day lists.

Through the courtesy of Professor A. V. Piper, there has been received at this station the following reputed species from the United States Department of Agriculture: L. cicera, L. sations, L. sativus azureus, $L$. satizus coccincus, L. sylkestris, L. sp. (India), L. Tingitanus, L. ochrus, L. pratensis, $L$. nervosus, $L$. sp., and $L$. sp. (not named).

The following species and varieties were received from dealers in seeds and plants:

Lathyrus latifolius, Henry A. Dreer, Philadelphia

Lathyrus latifolius albus, Henry A. Dreer 
Lathyrus latifolius White Pearl, Henry A. Dreer Lathyrus latifolins Delicata, Peter Henderson, New York

Lathyrus latifolius roseus, A. T. Boddington, New York

Lathyrus latifolius Pink Beauty, A. T. Boddington

Lathyrus latifolizs albus, A. T. Boddington

Lathyrus latifolius White, J. M. Thorburn \& Co., New York

Lathyrus latifolius Pink Beauty, J. M. Thorburn \& Co.

Lathyrus latifolizes splendens, R. \& J. Farquhar, Boston

Lathyrus latifolius Giant White, R. \& J. Farquhar

Lathyrus latifolizs Perennial Pea, Red, James Vick's Sons, Rochester

Lathyrus latifolius Perennial Pca, Rose, James Vick's Sons

Lathyrus latifolius Perennial Pea, White, James Vick's Sons

Lathyrus syliestris, J. M. Thorburn \& Co.

Lathyrus pubescens, A. T. Boddington

Lathyrus grandiflorus, Ellwanger \& Barry, Rochester

Lathyrus Lord Anson's Blue, A. T. Boddington

Lathyrus Lord Anson's Blue, J. M. Thorburn \& Co.

Lathyrus Lord Anson's White, J. M. Thorburn \& Co.

Orobus niger, J. M. Thorburn \& Co.

Orobus lathyroides, J. M. Thorburn \& Co.

Orobus albus roseus, Henry A. Dreer

Orobus superbus, Henry A. Dreer

Orobus vermus, Henry A. Dreer

Orobus vermus, R. \& J. Farquhar

Only a few of the above, mostly annual species, flowered the first year.

\section{Descriptions of the species}

\section{Annual}

\section{LATHYRUS SATIVUS L.}

Stems branching, smooth, winged, 2 feet high; leaflets linear-oblong; tendrils trifid; stipules semisagittate-ovate, ciliated, not so long as the petioles; peduncles $\mathrm{I}$-flowered, longer than the petioles $\left(\mathrm{I} \frac{1}{2}-2\right.$ inches long), bracteolate and articulate at the apex; calyx lobes lanceolate, foliaceous, almost three times length of tube; legumes ovate, short, broad, irregularly reticulated, winged on the back; seeds trigonal, smooth, truncate. Native of Spain, France, and Italy. Flowers blue, sometimes white, $\frac{3}{4}-\mathrm{I}$ inch in diameter. L. sativus, L. sativus azureus, and $L$. sativus coccineus were found at this station to be a mixture of white and blue forms. 


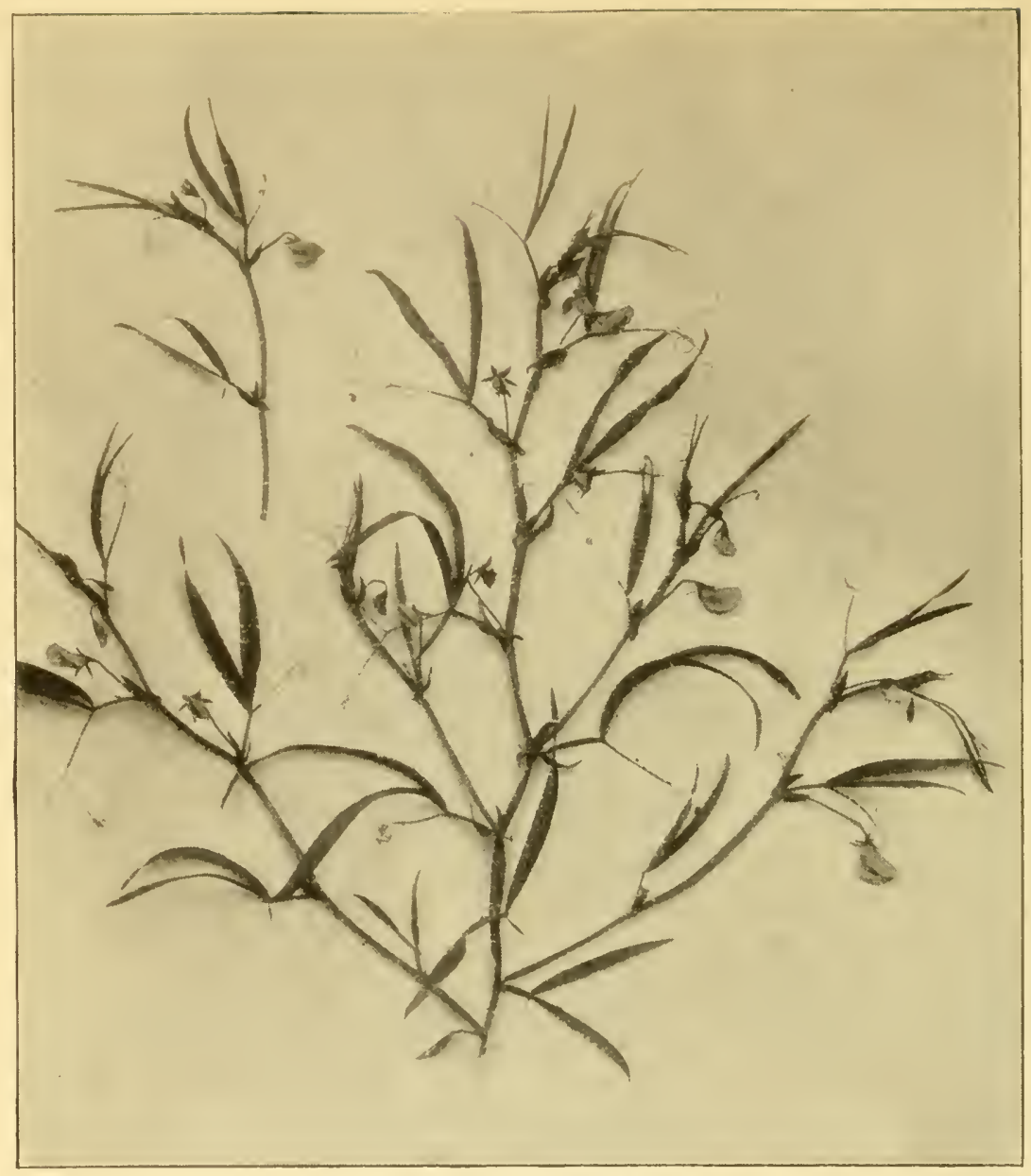

FIG. 178.-Lathyrus sativus $L$.

\section{LATHYRUS CICERA L.}

Stems smooth, 2 fect high, branching, winged; leaflets linear; tendrils branched; stiptiles semisagittate, narrow, much shorter than the petioles; peduncles I-2-flowered, length of the leaves; bracteoles small; calyx segments lanceolate, nearly three times length of tube; legumes oblong, irregularly channeled on the back, not winged; seeds trigonal, truncate, smooth. Native of Spain. Flowers purple or red, variable.

\section{LATHYRUS HIRSUTUS L.}

Stems winged, 2 feét high; leaflets lincar-lanccolate, 3-ncrved; stipules semisagittate, linear, about equal the petiole in length; peduncles usually 
2-flowered; calyx hairy, segments ovate-acuminate, length of tube; legumes oblong, hairy; seeds globular, warted. Native of southern Europe, in

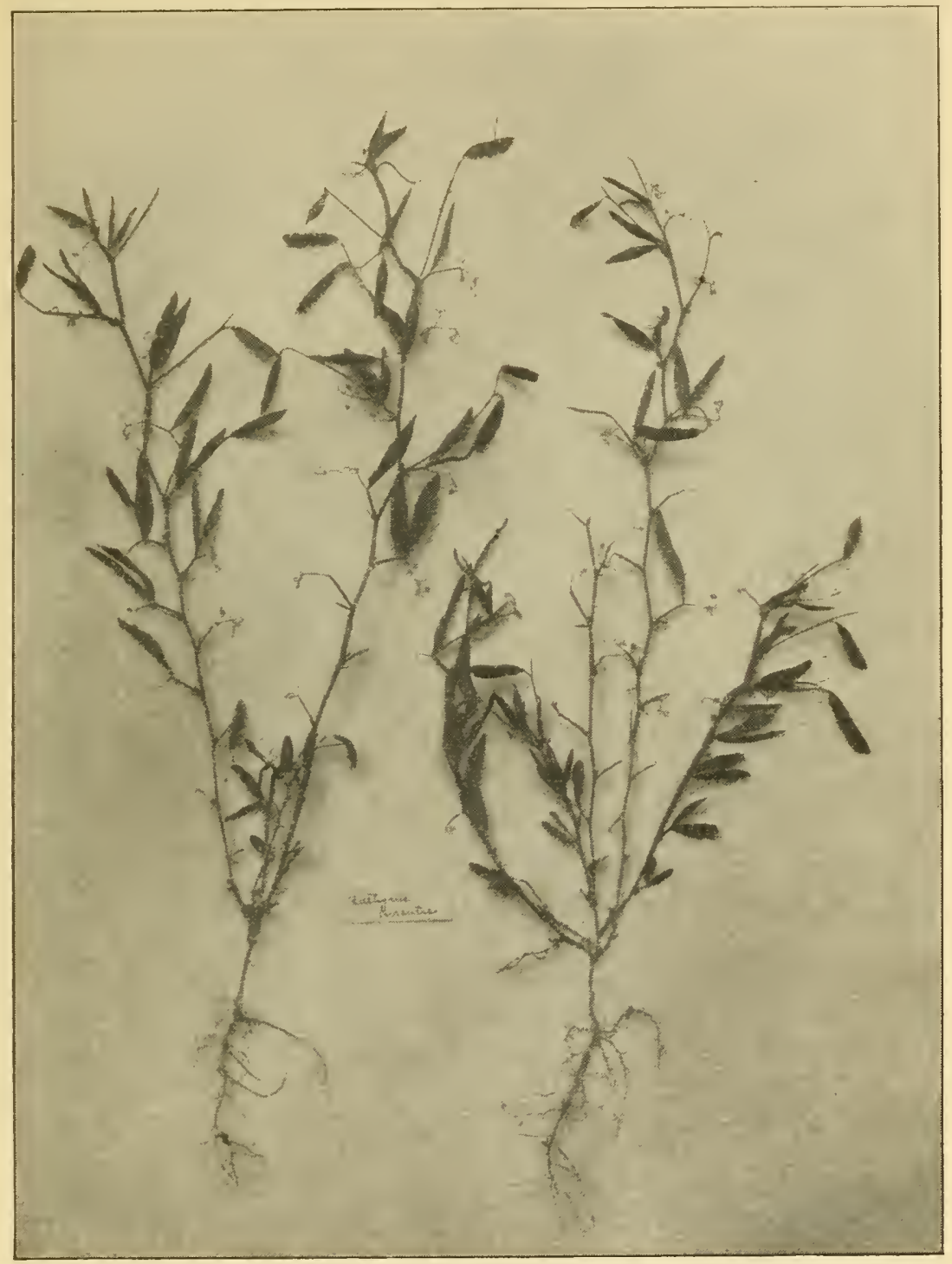

FIG. 179.-Lathyrus hirsutus $L$.

grainfields. Flowers with a bright crimson standard, pale blue wings and white keel. 


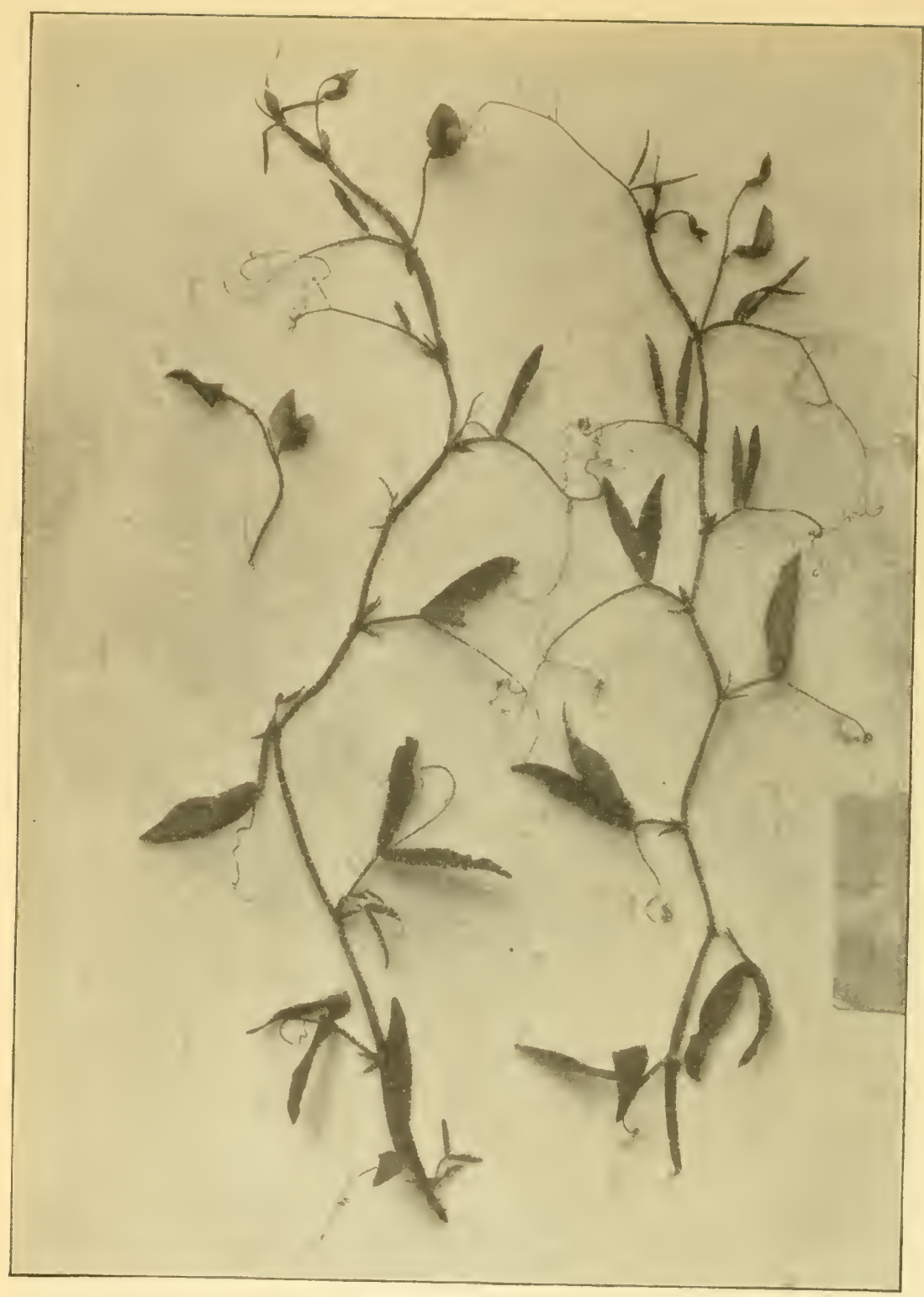

Fig. 180.-Lathyrus Tingitanus L. Tingier scarlet pea

\section{LATHYRUS TINGITANUS L.}

Stems spreading-winged, quite glabrous, 3 feet longr leaflets linearlanceolate, obtuse, mucronate; stipules lanccolate, much shorter than 


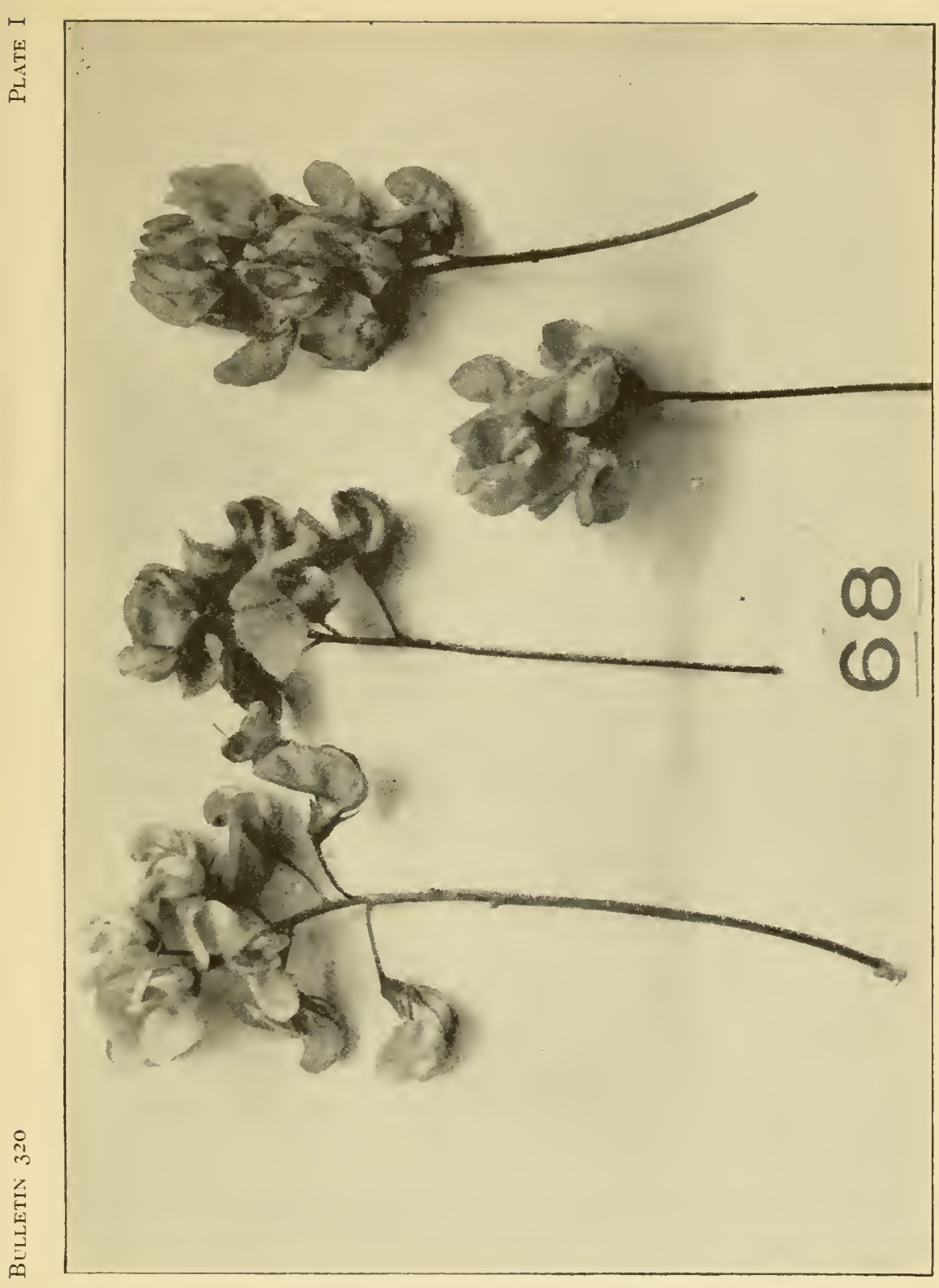

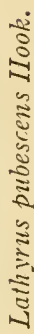

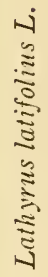



the petioles; peduncles 2-flowered, longer than the leaves; calyx teeth nearly equal; legumes linear, $4^{-5}$ inches long, much reticulated, compressed, sutures thick; seeds not angular. Native of the west Mediterranean region at Tangier. Flowers i inch long, dark red-purple: standard large, purple; wings and keel bright red.

\section{LATHYRUS ODORATUS L.}

Stems rough-hairy, winged oval or oblong, mucronate; stipules lanceolate, much shorter than the petioles; peduncle 2-4-flowered, much longer than the leaves; calyx teeth broad, longer than the tube; legumes compressed, linear, I-3 inches, hairy; seeds round, sometimes angled, black, white, or mottled. Native of Sicily. Flowers large, showy, in shades of blue, red, yellow, and white. Standard large-expanded, hooded or wavy.

\section{LATHYRUS OCHRUS DC.}

Stems 4-angled, winged; petioles winged, lower ones leafless, upper ones with two leaflets; leaves glaucous; lower stipules wanting, upper ones ovate; peduncle I-flowered; calyx teeth unequal, superior lobes shortest, length of tube; legumes with membranous wings, few-seeded; seeds globular. Native of southern Europe. Flowers pale yellow.

\section{Perennial}

\section{LATHYRUS SYLVESTRIS L.}

Stems straggling, 3-5 feet, stout, winged, glabrous, with creeping rootstocks; petioles winged, with one pair of linear-lanceolate leaflets; stipules narrow; peduncles 3-6-flowered, equaling the leaves; legumes compressed, reticulated, lanceolate, $2-3$ inches long; seeds round, dotted. Native of Europe, in woods and hedges. Flower with one-half-inch-long standard: standard rose, with a green spot on the back; wings purple at the tips; keel greenish.

\section{LATHYRUS PUBESCENS HOOK.}

A soft, hairy, diffuse-branching herb; stems $3-5$ feet high; stems, branches, and peduncles 4 -angled, the angles forming stout ribs; petioles with one pair, rarely two pairs, of leaflets, sessile, $I-2 \frac{1}{2}$ inches long, oblonglanceolate or elliptic-oblong, dark green, strongly ribbed beneath; stipules variable in size and form; peduncle longer than the leaves, many-flowered in lax or dense racemes; calyx tube broadly campanulate, upper teeth shorter; legumes linear, $2-2 \frac{1}{2}$ inches long, hairy, flat; seeds very small, ellipsoid. Native of South America, from Bolivia and southern Brazil to the Straits of Magellan. Flower variable in size, sometimes $1 \frac{1}{4}$ inch broad, violet-blue: standard round, notched at the tip, margins recurved, 
violet-blue; wings broad, spreading, pale lilac dorsally, nearly white in front; keel petals falcately curved, with red tips.

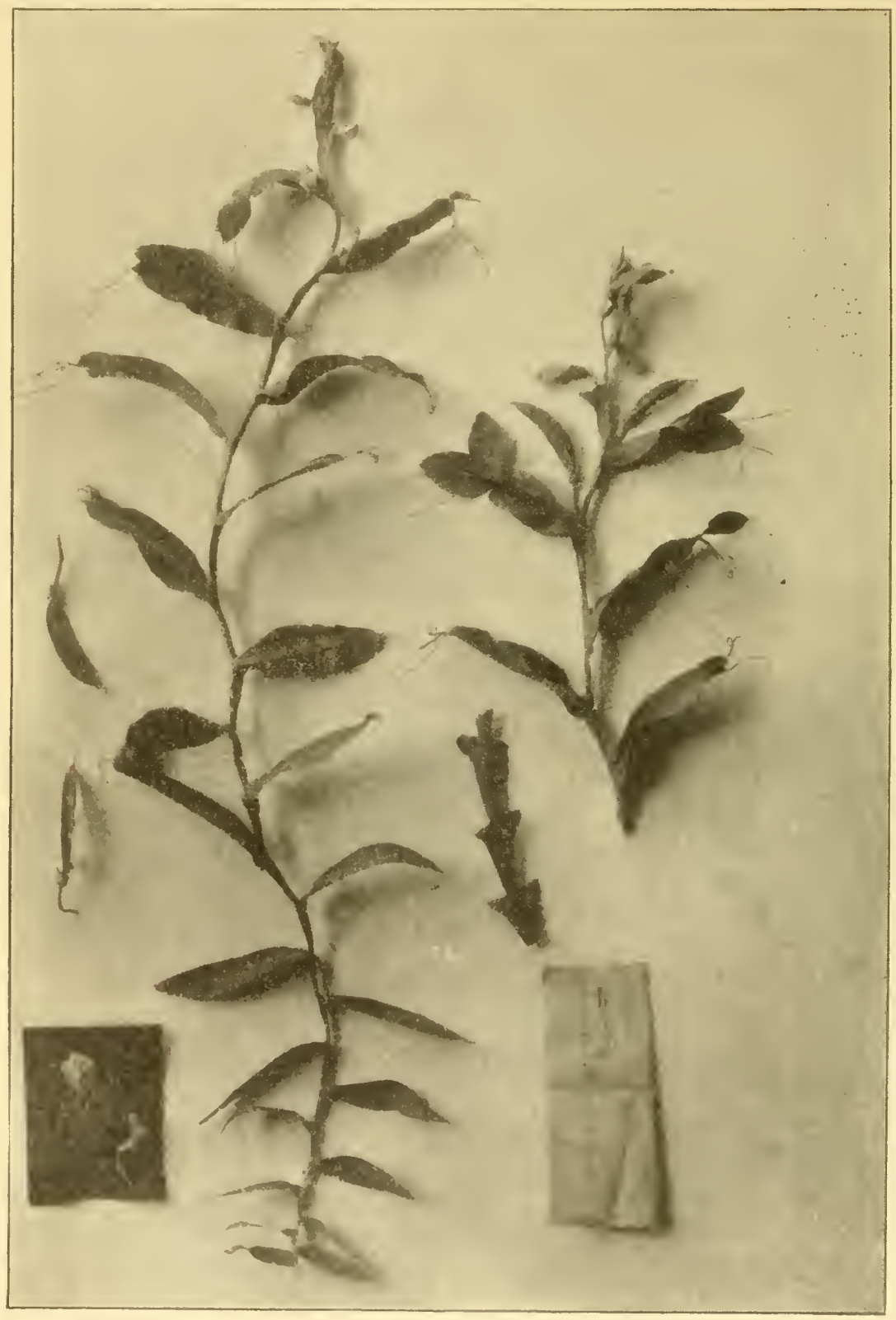

Fig. I8I.-Lathyrue ochrus $D C$. 


\section{LATHYRUS MAGELLANICUS LAM.}

Seeds of this species were received from two American seedsmen, but they proved to be the annual species, Lathyrus sations L. The Cyclopedia of American Horticulture describes this species as follows: "Stem 3-5 feet long, smooth, angled, somewhat branched; leaflets ovate or oblonglinear; tendrils branched; stipules cordate-sagittate, broad; peduncles long, 3-4-flowered; flowers dark purple-bluc. June, July. Straits of Magellan. . . . . A strong-growing, woody, almost evergreen species covered with a bluish bloom. . . . . . Var. albus Hort. . . . is the white form."

\section{LATHYRUS LATIFOLIUS L.}

Stems winged, 4-8 feet, glabrous; leaflets one pair, ovate-lanceolate, rather glaucous, mucronate, $2-3$ inches long; tendrils branching; stipules broad ovate; peduncles many-flowered, longer than the leaves; legumes long, flat, reticulated lengthwise, 4-5 inches long; seeds roundish, smooth. Native of Europe, in woods. Flowers large, rose-colored, but horticultural varieties occur with white, dark purple, and striped flowers.

\section{LATHYRUS NERVOSUS LAM.}

Stems triangular, striated, I-2 feet long; petioles with one pair of ovate, acute, mucronate, nerved, glaucous, glabrous leaflets, longer than the internodes; petioles very short; tendril branches long; stipules sagittate, nearly two thirds size of leaflets, nerved; peduncles many-flowered; calyx teeth unequal, upper ones shortest; pod $2 \frac{1}{2}$ inches, linear, glabrous, containing 7-8 seeds; seeds irregular in form, brown, with smooth coats. Native of the region about Montevideo. Flowers large, purple.

\section{LATHYRUS PRATENSIS L.}

Stems smooth, tetragonal, 2-3 feet; petioles with one pair of oblonglinear or lanceolate leaflets; tendrils usually unbranched; stipules ovate, shorter than the leaflets; peduncles many-flowered, twice the length of leaves; calyx nerved, teeth nearly equal; legumes compressed, obliquely reticulated; seeds globular, smooth. Native of Europe, in moist meadows. Flowers yellow.

\section{HISTORY OF THE CULTIVATED LATHYRUS}

The word "Lathyrus" is from the Greek $. \alpha, l a$, augmentative, and isovors, thouros, anything exciting, having reference to the qualities of the seeds of certain species. In Europe the species of Lathyrus are known as "Gesse," the sweet pea being known as Gesse odorante. The French know the plant under this name, or occasionally as Pois odorante 
and latterly as Pois de Senteur. The common Gesse of central Europe is Lathyrus satious.

Of the one hundred or more species of Lathyrus, very few are in cultivation. Some - as, for example, the sweet pea - are of ornamental value; others, such as Lathyrus sativus, are of economic value as forage crops.

The species are all propagated by seed, and the perennial species by division also. Occasionally cuttings have been used, and possibly the method could be extensively adopted.

With the exception of the swcet pea, which requires the best of soil and culture, the Lathyri are not exacting as to soil. Some of the perennial species appear to thrive in a rather poor, dry soil and are useful in covering banks. The perennial species have long, fleshy roots, and when established they thrive for years without special care. In fact, these species are best left alone.

\section{Descriptions of cultivated species}

\section{LATHYRUS SATIVUS L.}

Bluc-flowered lathyrus, or chichling vetch. An annual species, of easy culture. The flowers are sky-blue [Répertoire de Couleurs, the standard and wings forget-me-not blue 2-3 (217), back of the standard heliotrope I (I88)] or pure white. The plant grows to a height of 2 feet and flowers carly and profuscly. The season is not long, but probably successive sowings would provide for a longer display of the bright blue flowers. At least two crops a year can be grown.

Don has the following to say of this species, which is a native of Italy, Spain, and France and has probably been cultivated from the earliest times: "In several parts of the continent a light, white, pleasant bread is made of the flower of this pulse, but it produced such dreadful effects in the seventeenth century that the use of it was forbidden by an edict of George, Duke of Württemberg, in 1671 , which was enforced by two other edicts under his successor, Leopold, in 1705 and $17 \mathrm{I} 4$. Divernoy Fabbroni says that in I 786 the government there cautioned the peasants against its use.'

The effect of the use of the bread or seeds was that men and animals suffered from a rigidity of the limbs, which came on suddenly without any previous pain. The discase was regarded as incurable. Swine, horses, and pigeons suffered in this way, cattle grew lean; while poultry would not eat the foorl. Strange to relate, it appears that geese suffered no ill effects. It is recorded that if these seeds are mixed with one fourth or one half wheat flour, the bread made from them is harmless. The foregoing possibly explains the origin of the generic name. 


\section{LATHYRUS TINGITANUS L.}

Tangier pea. This species is very distinct from the sweet pea, $L$. odoratus, and is sometimes cultivated in gardens with other annuals. Its culture is similar to that of the sweet pea, but, while the flowers are freely produced, they lack the range of color and the agreeable fragrance of the sweet pea. The species begins to bloom with the earliest of the sweet peas, but experience last vear at this station would indicate that it does not produce flowers over so long a period. Success is dependent on prompt removal of the pods, for they develop rapidly. This plant comes from northern Africa.

\section{LATHYRUS OCHRUS DC.}

This species has pale yellow flowers, hence the common name, pale, yellow pea. The plant was formerly known as Ochrus pallida Pers. Linnæus described it as Pisum ochrus and De Candolle as Lathyrus ochrus, the latter being now the accepted name. The species is of the easiest culture, but is not very showy nor attractive in bloom. It does not remain in bloom very long, but is of some interest botanically.

\section{LATHYRUS SYLVESTRIS L.}

This species is inferior ornamentally to other spccies, but is of some value as a forage crop. It grows well on poor, sandy soil, which it improves if plowed under.

\section{LATHYRUS PUBESCENS HOOK.}

One of the most ornamental species, but is not hardy. The flowers are a beautiful blue - in fact they are said to surpass Lord Anson's Blue - and are borne several in a cluster. The species was first cultivated by $\mathrm{M}$. Andre in his garden at La Croix, France. The plant attains a height of 3 to 5 feet in cultivation. Early-sown seeds give plants that bloom the same season. This species may be increased from cuttings in the fall. In England the variety is a pparently not hardy except in favored locations, and is recommended as a greenhouse plant. It was exhibited before the Massachusetts Horticultural Society March 20, I906. Color plates are found in The Garden, Vol. 54, p. 353, and in Revue Horticole, I 895, p. 40. The latter is a better representation of the color of our species.

\section{LATHYRUS MAGELLANICUS LAM.}

In the old seed lists we find Lord Anson's Blue and Lord Anson's White. The plant most frequently sold under this name is Lathyrus sativus. The true species is a perennial, with woody stems 3 to 5 feet long bearing long, 3-4-flowered peduncles. The color is a purple-blue. 
"The history of the species," says C. Wolley-Dod, "dates from the celebrated voyage around the world of Lord Anson in the ship Centurion in $1740-1744$. The Centurion, with the crew in a dreadful condition from scurvy, reached the southeastern point of South America in the beginning of March, I 74I (equivalent in our season to September). The weather was then mild and bright, and it seems to have been at the entrance of the Strait Lc Maire that this pea was first found."

Martyn's edition of Miller's Dictionary says of it: "Mr. Miller has a perennial pea, which he calls Pisum Americanum, or Cape Horn pea, from its having been brought by Lord Anson's cook when he passed that cape, where this pea was a great relief to sailors; but it is not so good for eating as the worst sort cultivated in England."

The plant is known to gardeners from the beautiful portrait in Sweet's British Flower Garden, Series II, Table 344. It seems that after its cultivation in the Chelsea Garden it was lost until Sweet's time, when his illustration was made from a living plant in Messrs. Osborn's nurseries at Fulham. After this it was again lost sight of for a long time, until it was reintroduced in $\mathrm{I} 899$.

The Reverend Mr. Wolley-Dod says that the plants do not prove to be really perennial. Sweet makes the suggestion that, being a maritime plant native of a very stormy coast, it may require sprinklings of salt.

\section{LATHYRUS LATIFOLIUS L.}

One of the most valuable of the ormamental species, and the best known of the perennial species in this country. This plant is one of the best hardy perennials, being a vigorous, rank-growing climber bearing manyflowered peduncles in great profusion. The plant is suitable for covering low treliises or as a cover for rough places, low walls, rocks, and banks. It succeeds well in shade and grows rapidly. The plants resent frequent removal. There are several variety names in the trade, but the best, so far as we can determine them at present, are Pink Beauty, Delicata, Albus, and Splendens. Another name is Grandiflorus, which is confused with the species L. grandiflorus. The latter can be distinguished by the two(rarely three)-flowered peduncles, as the varieties of $L$. latifolius bear many-flortered peduncles.

\section{LATHYRUS PRATENSIS L.}

Common yellow vetchling, meadow vetchling, or tare everlasting. The old authors describe this as an ineradicable weed because of its creeping rootstocks. Later authorities recommend it as a food for cattle, since the quality is good and it produces a considerable quantity of succulent forage. 


\section{LATHYRUS NERVOSUS LAM.}

This species, under the conditions at this station, made stems I foot long and did not flower. It is quite distinct in its plant characters. The species was discovered by Mr. Cameron, growing on rocky places near Montevideo in Scuth America. It was first described by Doctor Vogel in Linnæa, Vol. I3, under the names $L$. nervosus and L. trigonus. It was first cultivated in England in the gardens of the Duke of Bedford, from seeds sent from Porto Bravo in southern Brazil. It is said to make a very satisfactory greenhouse subject, grown in pots and trained. 


\title{
PART II. THE SIVEET PEA IN BOTANY AND IN HORTICULTURE
}

\author{
"Here are sweet peas, on tip-toe or afight, \\ II'ith wings of gentle flush o'er delicate white, \\ And taper fingers catching at all things, \\ To bind them all about with tiny rings."
}

Keats.

HISTORY OF THE SWEET PEA

\section{Botanical history}

The earliest mention of the sweet pea was made in "Sillabus Plantarum Sicillæ-nuper detectarum a P. F. Franciscus Cupani" (Panormi, I695). It is a very small work - duodecimo - and among the plants newly discovered is the "Lathyrus distoplatyphyllos hirsutis mollis, magno et peramocno flore odoro." In I 696 the same writer issued "Hortus Catholicus Neapolitanus" (Neapoli). Father Cupani* exhibited considerable zeal in distributing this Lathyrus and in 1699 sent seed to Dr. Uvedale at Enfield, England, and to Caspar Commelin at Amsterdam, Holland.

Commelin published an illustration and description of the plant in his "Hort-Medici Amstelodamensis" (1697-1701). In his description he says:

"I am sowing seeds of this most elegant and very pleasant plant lately received from the Reverendo Patri Francisco Cupani, who was pleased to communicate with me and to send me these from Panormo, together with other somewhat rare seeds, in the beginning of I699; which being sown, in the same year produced flowers and seeds, of which plant, for the sake of the elegance and pleasantness which it possesses, I have wished to set forth a delineation and description by that name which the Revendus Pater Cupani has proposed for it in the catalogue of the most learned and excellent Catholic Prince.

"This Lathyrus, an annual, rises to a height of 6 or 7 feet; the root is thin, the stalks compressed, solitary, projecting on both sides on these stand two wide and oblong leaves on a foot stalk, which is compressed, foliated, and raised, which footstalk ends in tendrils. From the wings of the leaves on longer pedicels spring butterfly-like flowers which are large and have a purple standard, the remaining petals are sky-blue. These flowers have a very pleasant smell."

Commelin adopted Cupani's name for the plant.

* Father Cupani was a very devout and learned monk and an enthusiastic naturalist. He was born in 1657 and became a monk in $168 \mathrm{I}$, his order being located in the vicinity of Panormi. In addition to the two purely botanical works mentioned above he prepared an illustrated natural history of plants, fishes, animals, and so on, entitled "Pamphytum Siculum." This work was published in I 7 I2, following the death of Cupani in 1711 . 
The most noticeable thing about Commelin's drawing is the way in which the wings are spread laterally, possibly due to the liberties taken by the artist, for we also discover a seed pod near the top of the stem above the flowers.

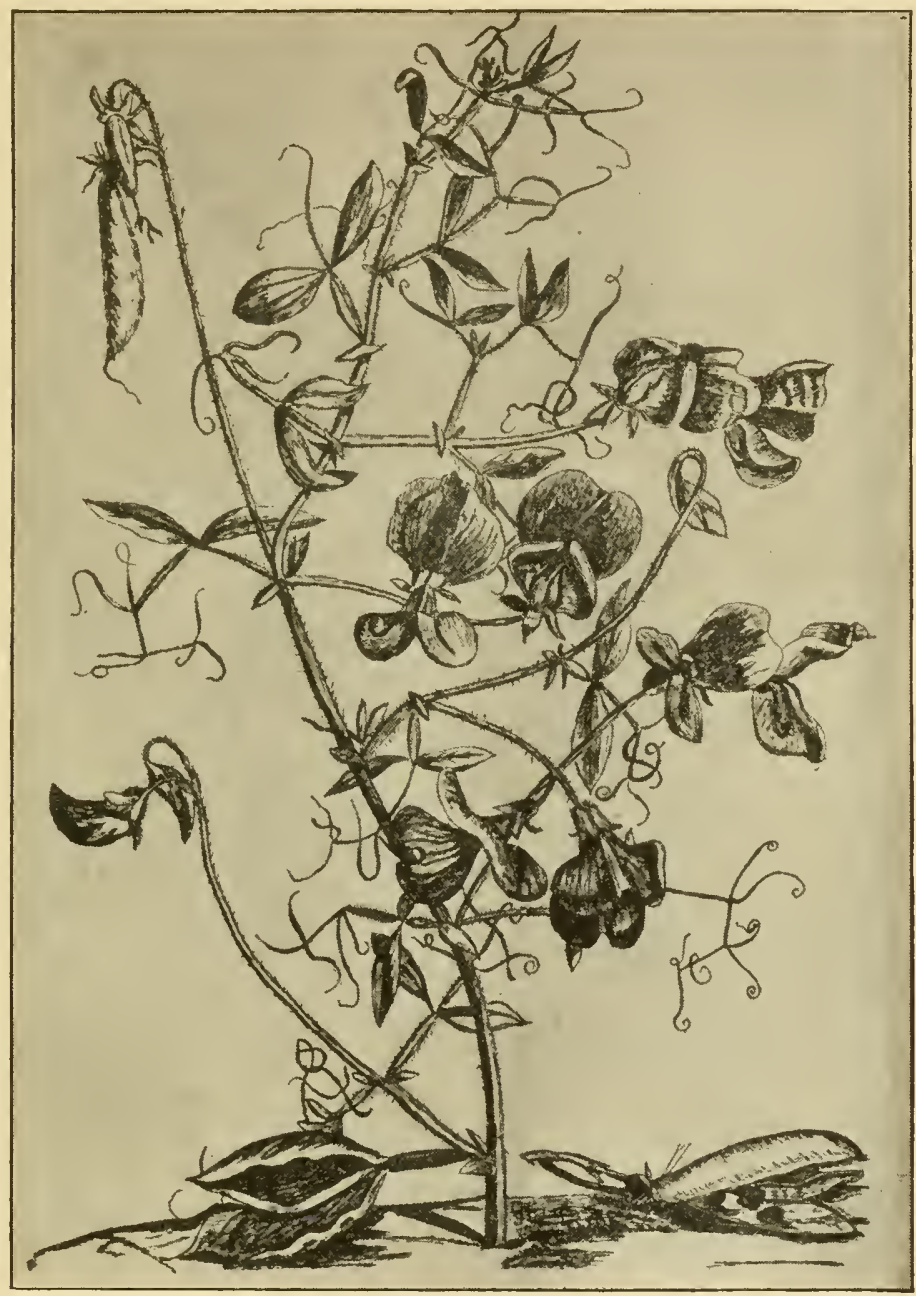

FIG. I 82.- The oldest drawing of the sweet pea, I70o. Commelin's drawing in Hort-Medici Amstelodamensis

Dr. Leonard Plukenet, * in his "Almagesti Botanici Mantissa " ( 700 ), gives a description of the sweet pea. A dried specimen of buds, flowers,

* Dr. Leonard Plukenet (I6.42-r706). Apothecary at Westminster. where he had a botanic garden. Became superintendent of the gardens at Hampton Court, and $\mathrm{Rc}_{2}$ al Professor of Botany. Published several botanical works. 
and leaves, preserved in Plukenct's Herbarium which forms a part of the Sir Hans Sloane Collection, is the oldest specimen of the sweet pea in existence. This specimen must date from about 1700 and undoubtedly came directly or indirectly from the garden of Dr. Uvedale.

John Ray,* author of "Historia Plantarum Generalis" (r688-r704), describes in the third volume of this work, which appeared in 1704 : "Lathyrus Major e Siciliae; a very sweet-scented Sicilian flower, with a red standard; the lip-like petals surrounding the keel are pale blue. Its seed pod is hairy." In the same connection he refers to the plant as "Lathyrus distoplatyphyllos hirsutis mollis, magno et peramocno flore odoratissimo purpureo." The last word has been added to Cupani's description on the authority of D. Sherard.

In I7r3 Mr. Petiver mentioned the plant in the Philosophical Transactions, in a paper entitled "Botanicum Hortense III " giving an account of divers rare plants observed that summer-A. D. I $/$ I $_{3}$ - in several curious gardens about London, particularly in the Society of Apothecaries Physick Garden at Chelsea. Pctiver calls the plant Lathyrus Siculus, citing Bocrhaave's "Index Plantarum quae Horto Academico Lugduno Batavo" ( 1 ro) as authority. The great Dutch naturalist considered his plant as identical with Cupani's L. distoplatyphyllos. Petiver describes the plants as coming from Sicily and having large, broad, sweet-smelling flowers, with a red standard (vexillum) and blue wing petals, or, as he describes them, " petalis labialibus," wrapping around the "rostrum," or young ovary. "This elegant sweet-flowered plant," continues Petiver, "I first observed with Dr. Plukenet† in Dr. Uvedale's most curious garden at Enfield, and since at Chelsea and elsewhere. Neither Gerard nor Parkinson mentions the plant, which must have been introduced after their time."

H. B. Ruppii, in "Flora Jenensis" (Francfort, I 7 I 8 ), places in a class of plants with irregular flowers, Lathyrus Siculus Ravini, and states: "In gardens they gencrally call it the musk-scented Lathyrus (L. moschatum). Sometimes it varies with a white flower." Now if we examine Ravini's "Introductio Generalis" (Lipsiae 1690-1699), we find that he figures "Lathyrus Siliquis hirsutis A., annual." He merely calls attention to the hairy pods, and this reference is extremely doubtful since there is a L. hirsutis, which is an annual, with hairy calyx and legume.

Thus far all the authoritics give Sicily as the original habitat of the sweet pea; and the forms then known were a variety with a red or purple standard and blue wings, and, according to Ruppii, a variety with white flowers.

\footnotetext{
* John Ray (1627-1705). One of the most distinguished of English naturalists. Author of many works, chief of which was " Historia Plantarum."

$\dagger$ Plukenet died in 1706 , therefore this sentence doubtless refers to observations made between $\mathbf{I 7 0 0}$ and 1706 and not to the summer of 1713 .
} 
Burmann, in 1737 , published his "Thesaurus Zeylanicus," wherein he mentions: "Lathyrus Zeylanicus odorato flore amoene ex albo et rubro vario, Nobis. Lathyrus Zeylanicus hirsutis flore variegato odorato Herb. Hart. This plant differs from the L. odorato of Cupani only in the variety of the flower, and since it has been well described and set forth in Hort. Amst., part 2, p. I 59, Fig. 80, we do not further describe it here, since also, in addition, these plants are well known to all since they frequently occur in our gardens."

Regarding the reference to Herb. Hart., Burmann says: "Hartog, or Hertog, is a herbarium which I keep and which contains very many most elegant Zeylanian plants, and was sent once by him from Zeylona to Cornelius Vossus, the gardener at Leyden." Burmann did not visit Ceylon, but received his specimens from others; and the early death of John Hartog, * who explored the island, prevented any correction of errors.

Linnæus, in "Hortus Cliffortianus," I 737, p. 368, gives the following:

"Lathyrus pedunculis bifloris, cirrhis diphyllis, foliis ovato-oblongis.

"Lathyrus siculus. Rupp. jen., 2 ro.

"Lathyrus distoplatyphyllos hirsutis mollis, magno et peramoeno flore odoro. Comm. Hort. 2, p. I59, t. 80, Boer. lugd. 2, p. 42.

"Crescit in Sicilia. Sii nomini sides."

Linnæus published a work on the plants of Ceylon in $\mathrm{I} 747$, but did not mention the sweet pea. In his "Hortus Upsaliensis, Stockholmiae" ( $\left.{ }_{748}\right)$ he referred to the sweet pea as follows:

" 4 Lathyrus pedunculis bifloris, cirrhis diphyllis, foliis ovato-oblongis, leguminibus hirsutis. Hort. Cliff., 368.

" $\alpha$ Lathyrus siculus. Rupp. jen., 2 го.

"Lathyrus distoplatyphyllos hirsutis mollis, magno et peramoeno flore odoro. Comm. Hort. 2, p. I59, t. 80.

" $\beta$ Lathyrus Zeylanicus. Odorato flore amoene ex albo et rubro vario. Burm. Zeyl., I 38.

"Habitat: $\alpha$ in Sicilia; $\beta$ in Zeylona.

"Hospitatur in ollis annua.

"Obf. Hacc coronaria, sauveolus, in $\beta$ vexillum rubrum alae albae carina alba apice rusescente."

From the above it will be seen that the great botanist makes two varieties, and recognizes first the Lathyrus Siculus of Boerhaave but gives the name of Commelin, who adopted that of Cupani, as a synonym; second, he admits the Zeylanian Lathyrus wholly on the authority of Burmann. It is thought by some that the omission of this plant from his work on Zeylanian plants led the botanists to call the attention of Linnæus

* John Hartog was trained in the Leyden Garden and made a journey to Ceylon at the instigation of Boerhaave and of William Sherard, Director of the Garden. He sent plants and seeds to Voss. He died in the prime of life from exposure and unsuitable food. 
to the fact and that the above classification was made to correct this omission.

Philip Miller, $\mathrm{I} 752$, gives " Lathyrus distoplatyphyllos hirsutis mollis, magno et peramocno flore odoro, Hort. Cath. Broadleaved, hairy, soft chichling with large and very beautiful, sweet-smelling flower, commonly called sweet-scented peas."

Linnæus, I 753, in his great "Systema Plantarum Europae," classifies the sweet pea as follows:

" Odoratus II. Lathyrus pedunculis bifloris, cirrhis diphyllis, foliis ovato-oblongis, leguminibus hirsutis. Hort. Cliff. 368, Hort. Upsal. 2 I6, Roy. lugd. 363.

"Siculus $\alpha$ Lathyrus Siculus. Rupp. jen., 2 Iо.

Lathyrus distoplatyphyllos hirsutis mollis, magno et peramoeno flore odoro. Comm. Hort. 2, p. 2 I 9, t. 80.

"Zeylanicus $\beta$ Lathyrus Zeylanicus. Odorato flore amoene ex albo et rubro vario. Burm. Zeyl., I 38 .

"Habitat: $\alpha$ in Sicilia; $\beta$ in Zeylona."

Here is the first use of the term "Odoratus" as a distinctive name.

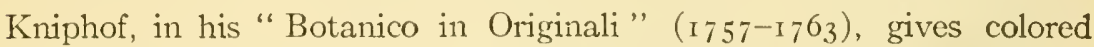
illustrations of the pressed flowers of Painted Lady sweet pea. In Vol. II the stems bear two flowers, and in Vol. V there is only one flower on a stem. S. B. Dicks, who has written much on the history of the sweet pea, thinks that the first illustration is from a dried specimen, sent from Ceylon. He says: "The colors are those of the Painted Lady as now grown, but the standards are small and of poor substance, the wings being in each case the most prominent parts of the flowers."

Mr. Dicks, who is an English authority on the history of the sweet pea, says that no mention is made of the sweet pea in Paoli Bocconi's "Icones Plantarum Siciliac" (Oxford, $\mathrm{I}_{74}$ ), which he regards as a rather remarkable fact. The writer has had an opportunity to examine this work, among others, and he finds that Bocconi does not mention Lathyrus, Vetch, Orobus, or, in fact, any of the Leguminosae. As proof that the Lathyrus odoratus did not occur in Sicily this work is worthless. However, Mr. Dicks called the attention of G. Sprenger to the facts regarding the origin of the sweet pea, and the latter undertook an investigation. Mr. Sprenger reported to Mr. Dicks as follows:*

"I retain that the plant is really a native of the two most important Italian islands, Sicily and Sardinia. I have just come from Sicily, where I could see the plant in the neighborhood of Corleone, a town lying in the interior on a range of hills, and in several other wild regions round

* "All about Sweet Peas," p. 21. 
about, together with other Papilionaceae. The plant has all the appearance of being of spontaneous form, and not an imported onc. The above locality has been but very rarely visited and it is apparently to be excluded that L. od. was brought there. It is surprising that the Lathyrus has been found in but a few places, but this does not mean much. From what I could deduct, the plant grows in three or four places in Sicily and it has also been found in Sardinia.

"Our most learned men retain that the Lathyrus is really an indigenous kind in Sicily, because it presents all the characters of being of spontaneous growth. The flowers of our kind are purple (purpurea), while those of Ceylon are rose-colored. This could be a variation due to the climate, but I was unable to find out if the Lathyrus varies or if the white-flowered variety is found growing spontaneously."

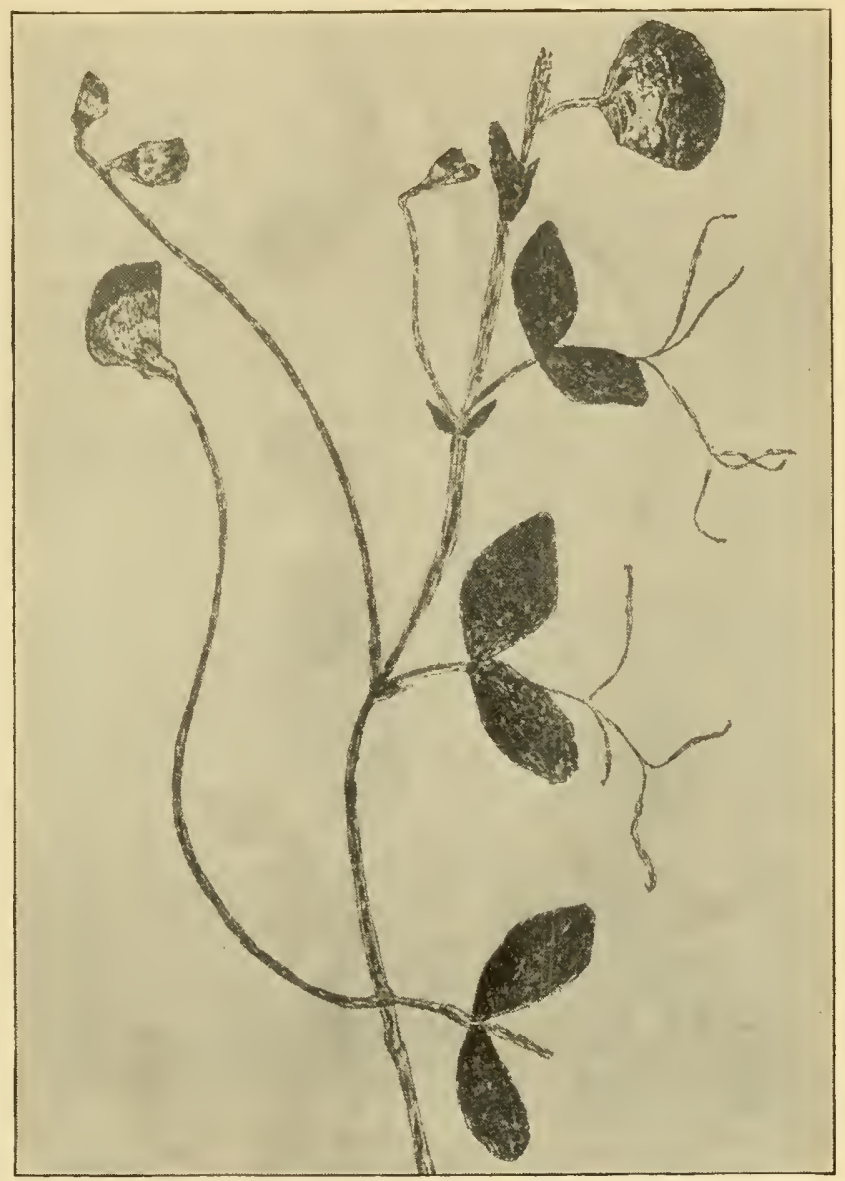

Fig. 183.-Kniphof's figure of the sweet pea. (Kniphof, Botanico in Originali, $1757-1763$ )

It has already been noted that the early writers considered Sicily as the native country of the sweet pea. Burmann was the first to catalog a sweet pea from Ceylon, which he admitted differed only in the color of the flowers from the Lathyrus described by Cupani. However, he proceeded to found a new species upon the sole character of difference in 
color of the flowers. Linnacus, writing a flora of Ceylon ten years later, did not describe a sweet pea from there. Neither of these botanists visited the island, and none of the later works on the plants of Ceylon, including those of Trimen, mention Lathyrus odoratus as native of that island.

The great mass of evidence, therefore, is in favor of Sicily as the original home of the sweet pea. The question arises as to how Burmann could have been misled. May it not have happened that Voss had seeds of the sweet pea which were accidentally mixed or included with the collection of Ceylon seeds? The color of the flowers was different from existing varieties, being red and white. That this would naturally be the direction of variation is shown by the fact that the first Cupid was white, while the second variety, Pink Cupid, was red and white. The first of Burpee's bush form was of this color, which is an extrenely precocious color. It would appear, since the swect pea is never found in Ceylon, and also from the fact that Burmann was aware that his plant differed only in color of the flowers from Cupani's plant, that Lathyrus Zeylanicus Burm. was only a variation from the original form received from Sicily in 1699 .

\section{British horticultural history}

The earliest trade mention of sweet peas, according to Beale,* is found in the catalog of Benjamin Townsend ( 1724$)$, who subscribes himself late gardener to Lord Middleton. He merely quotes sweet pea seed.

Robert Furber offered seed of the purple variety of sweet pea.

In "Twelve Months of Flowers" ( 1730 ), a set of engravings designed by Peter Castcels from the collection of Robert Furber, gardener at Kensington, and engraved by H. Fletcher, is to be found probably the first colored illustration of the sweet pea. The purple sweet pea is shown in the bouquet for the month of June. The form of the flower is very loose and irregular, with a small reflexed standard and very large wings.

In Miller's Gardeners Dictionary, first folio edition, 1731 , is found the following, referring to the culture of Lathyrus Tingitanus and Lathyrus distoplatyphyllos:

"The fifth and sixth sorts are annual plants which are propagated only by secds: these may be sown in March in the place where they are to remain for good; being plants that seldom will grow, if transplanted, except it be done when they are very young. These should be sown near a Pale, Wall, or Espalicr, to which they may be trained, or, if sown in the open borders, should have stakes placed by them, to which they shoukd be fastened; otherwise they will trail upon the ground and appear very unsightly; which is the only culture these plants require; except the

* Gilbert Beale, in Gardening World, 1000, $\mathrm{pp}, 7+1,7+2$, and 765. 
cleaning of them from weeds. They produce their flowers in July and their seeds are perfected in August and September. But the best method to have them very strong is, to sow their sceds in August under a warm wall or hedge where they will come up in the autumn and abide the winter very well; and these will begin to flower in May and continue to produce fresh flowers until July or later, according to the heat of the season; and one of these autumnal plants will be as large as four or five of those sown in the spring and produce ten times the number of flowers; and upon these plants you will always have good seeds, when sometimes the other will miscarry; however, it is very proper to sow seeds at two or three different seasons in order to continue their flowers the longer; for the lateplanted ones will continue blowing until the frost prevents them.

"The srreet-scented sort is the most valuable both for beauty and fragrancy of its flowers. Of this sort there are two other varieties: one of these has pale red flowers, which are called by gardeners Painted Lady peas; the other hath entire white flowers; both these may be allowed a place in the borders of the flower garden for the sake of variety."

From the preceding it is clear that three varieties were known at least as early as $173 \mathrm{I}$. In the eighth edition of the Gardeners Dictionary, I768, the same varieties are again noted.

James Justice, in the Scots Gardeners' Director ( 1754 ), criticised the catalogs of the Dutch seedsmen and nurserymen who were sending their catalogs throughout England. He says, " They are neither rightly named botanically or otherwise," and for illustration proceeds to quote from the "Caalogus van Schoone Bloem-Zaaden te Vinden," by Dirk and Pierre Voorhelin, "Bloemists te Haarlem": "No. I76 Lathyrus odorante flore albo et rubro variegato"; "No. I77 Lathyrus odorante flore purp. et rubro variegato."

Justice then proceeds as follows: "The first named is the Lathyrus angustifolius flore ex albo et rubro variegato odorato, mentioned by J. Bauhinus, 1650. This is the Painted Lady pea vulgo, a variety seminal of the $I_{77}$ but not so sweet-smelled." Regarding No. I 77 he says: "This is the Lathyrus distoplatyphyllos of Hort. Cathol., the sweet-scented pea vulgo; of this kind of pea there is both the purple and the white flowered forms."

In the catalog for ${ }_{7} 77 \mathrm{~S}$ of $\mathrm{W}$. Malcolm, seedsman, of Kensington Turnpike, there were offered white, purple, and Painted Lady sweet peas.

The Universal Gardener and Botanist of Mawe and Abercrombie, I 778 , gives under Lathyrus: "Varieties of, are, purple-flowered sweet peas, whiteflowered sweet peas, variegated or Painted Lady sweet-scented pea."

The first evidence of improvement is noticed in the catalog of John Mason (original founder of the business of Cooper, Taber \& Co.), published 
in 1793 at The Sign of the Orange Tree in Fleet Street. He offered black, purple, scarlet, white, and Painted Lady peas.

In Martyn's edition of Miller's Gardeners Dictionary, I807, the sweet pea, with its varieties, is classified with the Lathyri:

\section{"With two-flowered peduncles:}

" Lathyrus odoratus................... Sweet Lathyrus or pea L. Spec. 1032, Reich. 3. 465, Hort. Cliff. 368, Upsal. 2 16, Curtis Mag. 60 Floribus albus. . . . . . . . . . . . . White-flowered sweet pea Alis carinaque albis, vexillo carneo........... Old Painted Lady pea Alis carinaque carneis, vexillo rubro.......... New Painted Lady pea Alis carinaque pallide cocruleus, vexillo atropurpurea ... Common sort Carina pallicle violacea, alis faturate violaceis, vexillo atropurpureo Peduncles two-flowered, tendrils two-leaved, leaflets ovate-oblong, legumes hirsute.

"The sweet pea, as it is commonly called, is an annual plant which rises from three to four feet high by means of its long, clasping tendrils. The flower stalks come out at the points, are about six inches long, and sustain two large flowers which have a strong odour; and are succeeded by oblong, hairy pods having four or five roundish seeds in each.

"In the common sort the corolla has dark purple standards, with the keel and wings of a light blue. Other varieties are the white; the pink with a white keel and wings pale blush color; the rose-coloured standard with keel and wings pale blue; these that have a mixture of red with white or a pale blue are called Painted Lady dies. There is also a varicty of the common dark sort with the keel pale violet and the wings dark violet, etc."

Page, in his "Prodromus" ( $\delta_{I_{7}}$ ), mentions a striped variety.

Thorburn, in 1824 , catalogued the following varicties of sweet peas:

" Painted Lady - Lathyrus odoratus fl. carnca

White-Lathyrus odoratus fl. albo

Black - Lathyrus odoratus fl. obscuro

Purple-Lathyrus odoratus fl. purpureo

Scarlet - Lathyrus odoratus fl. roseo "

A yellow sweet pea is designated as Lathyrus aphaca. In 1827 the same firm offered a striped variety.

Roland Green, whose "Treatise on the Cultivation of Ornamental Flowers" (Boston, ${ }_{1} \delta_{2} 8$ ) was the first distinctly floricultural book published in North America, speaks of sweet peas as follows:

"Pea, sweet (Lathyrus odoratus) - There are many species as to color and fragrance. These are annual. The Everlasting Pea (Lathyrus C. folius) is perennial and produces many clusters of showy flowers, and 
remains in bloom a long time. The seed should be planted early in the spring."

Edward Sayers, whose book "The American Flower Garden Companion" (Boston, I838) was the second floricultural book published in America, gives in the appendix of the book the following list:

"Sweet pea, Painted Lady, Lathyrus odoratus. . 4 4 ft. fleshed color White sweet pea Lathyrus alba ......... $2 \mathrm{ft}$. white color

Purple sweet pea Lathyrus fl. purpurea...... 2 ft. purple color

Scarlet sweet pea Lathyrus fl. rosea......... 2 ft. scarlet color

Striped sweet pea Lathyrus fl. striata........ 2 ft. striped color "

Thus we see that all the varieties were known in this country previous to 1840.

Mr. Carter (founder of Messrs. J. Carter \& Co. of Holborn) offered in $1 \delta_{37}$ the five varieties previously offered by Mason, and also the striped variety.

In Mrs. London's "Ladies' Flower Garden of Ornamental Annuals " (I840) descriptions are given of a number of annual species of the genus Lathyrus, among them L. odoratus. Under the head of "Varieties" occurs the following: "There are six distinct kinds of sweet peas in constant cultivation, all of which, with very few exceptions, come true from seed. There are the purple, which has a standard of deep reddish purple, the wings pinkish, and the keel nearly white, and is a native of Sicily; the New Painted Lady, which has the standard dcep rose colour, the wings pale rose, and the keel pure white, and is a native of Ceylon; the white sweet pea, which has flowers a pure white; the Old Painted Lady, which has the wings and keel white and the standard flesh-coloured; the blue, which has the wings and keel a palc blue and the standard dark bluish purple; and the violet, which has the keel a pale violet, the wings a deep violet, and the standard a dark reddish purple."

Between 1845 and 1849 the firm of Messrs. J. Carter \& Co. introduced a New Striped Sweet Pea and a New Large Purple Sweet Pea.

In $185^{\circ}$ Messrs. Noble, Cooper \& Bolton (predecessors of Cooper, Taber \& Co.) introduced a New Large Dark Purple.

In $1860 \mathrm{Mr}$. Carter offered nine varieties, besides a yellow-flowered variety and the variety Blue Edged. The last-named variety was white, with a well-marked blue edge, and it was stated that it was the result of many experiments made by Major Trevor Clarke, of Daventry, in crossing a pure white sweet pea with the perennial bright-blue-flowered Lord Anson's pea, L. Magellanicus. Later, in $188_{3}$, under the name "Blue Hybrid," this variety received the First Class Certificate of the Royal Horticultural Society. 
It was in 1865 that the First Class Certificate of the Royal Horticultural Society was first awarded to a new sweet pea. This was the variety called Scarlet Invincible, exhibited by Steven Brown, of Sudbury, and offered in Carter's catalog for 1866 , where it was both described and illustrated. This was the first illustration of a sweet pea novelty ever published in a seedsman's catalog.

James Vick's "Illustrated Catalogue and Flower Guide" for 1870 , under the division of Ornamental Climbers, gives the following varieties of sweet peas: Scarlet, Scarlet striped with White, White, Purple striped with White, Painted Lady, Blue Edged, Black, Black with Light Blue, and Scarlet Invincible.

The prices may be of interest, for Mr. Vick says: "I am so desirous to encourage the general culture of this swect flower that I have made the price very low - the papers are large and the price by the pound and ounce about cost." The first five varieties were offered at ro cents per packet, 20 cents per ounce, $\$_{3}$ per pound; Blue Edged, 30 cents per ounce, $\$ 4.50$ per pound; the last three, 15 cents per packet, 40 cents per ounce, $\$ 6$ per pound; mixed seed, Io cents per ounce, $\$$ I per pound.

About this time (previous to i 870 ) Messrs. Haage \& Schmidt, of Erfurt, sent out Crown Princess of Prussia, the beautiful light pink variety. In I $S_{73-1} S_{74}$ the same firm sent out Fairy Queen, which was a leading variety for many years. Butterfly, quite similar to Blue Edged, was introduced by Sutton \& Sons in 1878 . A color plate of this appeared in The Garden, Vol. I3, I 878 , p. 44.

Messrs. Carter had the honor of publishing the first colored illustration of a new sweet pea to appear in a seedsman's catalog, when they sent out Violet Queen in $18_{77}$.

Prior to ISS I the following varieties had appeared: Purple, White, Painted Lady, Scarlet, Black, Purple, Striped White, New Painted Lady, Large Dark Purple, Yellow, Blue Edged, Scarlet Invincible, Scarlet striped with White, Black Invincible, Crown Princess of Prussia, Fairy Qucen, Purple Invincible, Invincible Striped Violet Queen, Heterosperma, The Queen, Captain Clarke, and Imperial Purple. The opening decade (I880), however, was to witness great things for the sweet pea, for about this time two capable florists began work on the improvement of the flower. Those men were Thomas Laxton and Henry Eckford.

Mr. Laxton, of Bedford, commenced about $1 S_{7} 7$ and for sereral years worked assiduously in this field. In $\mathrm{IS}_{3}$ he won a First Class Certificate from the Royal Horticultural Socicty for the excellent variety Invincible Carminc. It is saic that this variety is the earliest recorded from crossfertilization, for, although the exact varieties are unknown, it was a cross of a red-flowered with a.purple-flowered variety. Mr. Laxton appears 
to have made many crosses, using the best varieties known at the time as well as his own best seedlings. Among the varieties introduced by him are Etna, Madame Carnot, Invincible Blue, Carmen Silva, and Rising Sun.

After Mr. Laxton's death the work was carried on by his sons, who introduced Princess May and Sultan. They also made crosses of the Cupids, of which mention is made under that division of our subject.

Mr. Eckford began his work of improving sweet peas about i 870 , while in charge of the gardens of Doctor Sankey at Boreatton. His collection consisted of the varieties known as White, Scarlet, Black, Painted Lady, and Butterfly. Later he started in business for himself at Wem, Shropshire, a small village but a place which he has made famous throughout the world. Here he worked, crossing and intercrossing all the varieties. His first notable result was Bronze Prince, which was exhibited before, and awarded a First Class Certificate by, the Royal Horticultural Society, August 8,1882 . This variety was sent out by W. Bull. Year by year the introduction of new varieties was forwarded, despite the claims of some persons during the earlier years that Mr. Eckford's varieties were no better than existing varieties. Steadily he kept at work, bringing out new varieties that were of improved size, form, or color. In the early nineties his varieties caused a sensation in America, and under the leadership of the Reverend W. T. Hutchins there was great enthusiasm in growing sweet peas for exhibition, and above all for home decoration. This supplied the required stimulus, largely lacking at home, for Mr. Eckford to put forth his best efforts, and the result is the remarkably long list of meritorious varieties that he sent out.

Aside from Bronze Prince, the following are some of the early Eckford varieties: Blue King, Charming, Duchess of Albany, Princess, Grandeur, Emperor, Black Prince, Leviathan, Rosalind, Maggie Ewing, Salmon Queen, Lavender Gem, Empress Victoria, Queen of Roses, Queen of Stripes, Purple Qucen. How many of these were introduced we have been unable to ascertain.

In 1885 Mr. Eckford introduced Queen of the Isles and Grand Blue; in 1886 or previously, Cardinal, Indigo King, Princess of Wales, and Miss Ethel. These were offered in the United States by Joseph Breck in I886. The varieties introduced in 1885 , together with Miss Ethel, were also offered by Peter Henderson.

In I887 Mr. Eckford sent out Duchess of Edinburgh, Imperial Blue, Isa Eckford, Orange Prince, and The Queen. These were offered by Breck the same year. Miss Hunt was also probably sent out this year. The following varieties were sent out in succeeding years:

In r888, Apple Blossom, Borcatton, Mauve Queen, Queen of England, and Splendour. 
In $18 S 9$, Captain of the Blues, Delight, Mrs. Gladstone, Mrs. Sankey, anci Purple Prince.

in isco, Alha Magria, Countess of Radnor, Lottic Eckford.

In $1 S_{9} 1$, Dorothy Temmant, Duke of Clarence, Enipress of India, Mionarch, Princess Victoria, and Senator.

In ISq2, Emily Lekford, Her Majesty, Ignea, Lemon Queen, Mrs. Eckford, and Warerly.

In 1893 , Blushing Beauty, Firefly, Gaicty, Lady Beaconsfield, Lady Penzance, Ovid, Peach Blossom, Royal Robe, Stanley, and Venus.

In I 894 , Blanche Burpee, Duke of York, Duchess of Tork, Eliza Eckford, Meteor, Mrs. Joseph Chamberlain, Novelty, and The Belle.

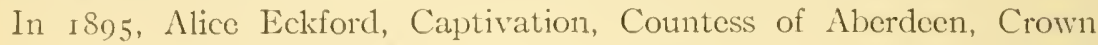
Jewel, Little 1)orrit, and Mikado. These were offered by the Reverend Mr. Hutchins in I 896 .

In r 896 , Coquette, Countess of Shrewsbury, Lorely, Mars, Prima Donna, and Royal Rose, which were offered in the United States in 1897 by Burpee and the Reverend Mr. Hutchins.

In 1897 , Countess of Powis, Lady Nina Balfour, Prince Edward of Tork, Queen Victoria, Triumph, Salopian, and Shahzacia.

In r $\$ 98$, Black Knight, Chancellor, Colonist, Duchess of Sutherland, Lady Grizel Hamilton, Lady Mary Currie, and Prince of Wales.

In I899, Countess Cadogan, Duke of Westminster, The Honorable F. Bouverie, Lady Skelmersdale, Mrs. Dugdale, Othello, and Sadie Burpee.

In r goo, Calypso, Countess of Lathom, Duchess of Westminster, Fascination, Lord Kenyon, and Mrs. Fitzgerald.

The two-hundredth anniversary of the introduction of the sweet pea was celebrated by the Sweet Pea Bi-Centenary Celebration in London in Inoo. Including the introductions of that year, there had been two hundred and sixty-four varietal names of the tall-growing type of sweel peas catalogued. This included all the indeterminate varicty names, as Purple, Purple Black, Purple Brown, Purple Striped, Light Blue and Purple, Red Striped, Striped Red and White, Striped Scarlet, Scarlet, Dark Red, Red striped with White, and so on; also, slight variations in color, form, and the like, as Striped Celestial, Light Gaiety, Extra Early Blanche Ferry, New Countess, and others, as well as the double sweet peas.

Out of this extensive list not more than one hundred and seventy-five varieties had been catalogued by any sced firm; the remainder were scattering introductions, some of which were not listed for more than one year. Mr. Eckford is responsible for one hundred and fiftecn varieties. The relative superiority of the Eckford varicties is seen when we examine the lists of this period, for we find, for example, in IBurpec's catalog for Isng, one hundred and forty varieties exclusive of doubles and cupids, 
and eighty of those are varieties originated at Wem. One fifth of the remainder are of the old varieties introduced prior to is8o. As late as 1907 we find that in Mr. Morse's list of the fifty leading varieties, based on the amount of seed of each demanded by the trade, twenty-eight of the varieties originated on Eckford grounds. In his selection of the best fifty varieties Mr. Morse included thirty-one Eckford varieties - a truly remarkable record of achievement for one man as against the field, especially when we take into consideration also the fact that after Mr. Eckford had "broken the type " many of the results obtained in California were rendered possible.

Mr. Eckford's further introductions are as follows:

I901, Coccinea, George Gordon, Honorable Mrs. E. Kenyon, Lady Ormsby-Gore, Miss Wilmott.

I902, Gracie Greenwood, Jeannie Gordon, Lord Rosebery.

I903, Agnes Johnston, Dorothy Eckford, King Edward VII, Mrs. Walter Wright.

1904, Mrs. Knights-Smith, Marchioness of Cholmondeley.

I905, Black Michael, David R. Williamson, Princess Maud of Wales, Romolo Piazzani.

1906, Henry Eckford, Queen Alexandra, Sybil Eckford.

I907, Agnes Eckford, Earl Cromer, Horace Wright, Maud Guest, Queen of Spain.

I 908 , H. J. R. Digges, James Grieve, May Perrett, Mima Johnston, Primrose Waved, Purple King, White Waved.

I909, Annie B. Gilroy, Dodwell F. Browne, Mrs. Charles Masters.

I910, Mary Vipan, Mrs. E. Gilman, Vicomte de Janze.

\section{American horticultural history}

The first American variety of sweet peas was that epoch-making variety, Blanche Ferry, introduced by D. M. Ferry \& Co. in i 889 . It was delineated by a colored plate, which was the first colored plate of a sweet pea to appear in an American seed catalog. This variety was derived from the Old Painted Lady.* Then followed Captain Sharkey (Breck, I889), Joanna Theresa (Breck, I889), Alba Magnifica (Henderson, I89 I), Blushing Bride (Breck, I891), and Emily Henderson (Henderson, I893). The last-named variety was for many years the standard white, and florists especially preferred it. In I $S_{94}$ W. Atlee Burpee \& Co. introduced American Belle, and Breck sent out Harvard. In I895 D. M. Ferry \& Co. introduced Extra Early Blanche Ferry and Katherine Tracy. In 1896 Burpee sent out Daybreak, originated by the Reverend Mr. Hutchins, and also Grey Friar, Juanita, Oddity, and Ramona. The

\footnotetext{
* For an account of the origin of Blanche Ferry, see Bulletin 319 of this station, page 625 .
} 
same year James Vick's Sons introduced the first of the double class in Bride of Niagara, which was a double strain of Blanche Ferry or its prototype. The sensational novelty Cupid, which is the most extraordinary departure yet found among swect peas, was sent out in this year also.

Mr. Burpee's introductions for 1897 included Aurora, Brilliant, Creole, Golden Gate, Maid of Honor, and Wawona. Mr. Iynch distributed California, Emily Lynch, and the Bride. 'The Sunset Seed Company introduced Golden Gleam and Red Riding Hood - the latter being the first of the Snapdragon type. Mr. J. C. Vaughan sont out America, the best of the stripes. Mr. Walker sent out Coronet. Mr. Breck distributed Snowflake, and the Reverend Mr. Hutchins sent out Columbia.

The new varieties introduced by Messrs. Burpee in in 898 were Dolly Varden, Lottie Hutchins, Modesty, Oriental, Sensation, and Stella Morse. In I899 the same firm sent out Fashion, Gorgeous, Navy Blue, Pink Friar, and also the first of the bush type, namely, Crey Friar Bush. Mr. Walker sent out Oregonia.

In 1900 Burpee distributed Admiration, Surprise, Snapdragon, and Sunproof Salopian; in 1901, Majestic; in 1902, American Queen, Golden Rose, Salvation Lassie, and Reselected Extreme Early Earliest of All. Messrs. Ferry sent out Josephine White and Inconstancy.

In i 903, Janet Scott, Sut Earl, and Dainty were distributed by Burpee.

During I904, Earliest Sunbeams and White Wonder were sent out by Burpec; Mr. Vaughan distributed Bridesmaid, Evening Star, Flora Norton, Florence Fraser, Mrs. George Higginson, Jr., Speckled Bcauty, Sunrise, and Sunset. Messrs. Morse and Vaughan each introduced Nymphaea, and Morse sent out also Shasta.

In 1905 Burpee introduced Mrs. Sydenham. (This name was dropped for Helen Lewis, which name was adopted by the English National Sweet Pea Socicty.) Morse introduced Helen Picrce. Henderson sent out Phenomenal and Domino.

In I906 Burpee distributed Earliest White.

In I907, Brilliant Blue was sent out by Burpee and Mr. Vaughan introduced Coral Gem.

The new American sweet peas for igo8 included Burpee's Apple Blossom, Spencer, Primrose Spencer, and Write Spencer. Messis. C. C. Morse \& Co. introduced Florence Morse Spencer.

In ino9 Messrs. Morse introduced Captain of the Blues, Spencer, Flora Norton Spencer, and Tennant Spencer. The varieties Aurora Spencer, Asta Ohn Spencer, Beatrice Spencer, King Edward Spencer, Mrs. Routzalin Spencer, Mrs. Sankey Spencer, Ramona Spencer, Queen Victoria Spencer, and Lovely Spencer were catalogued by Burpee and by Morse for the first time in this year. 
Miriam Beaver, Maric Corelli, Senator Spencer, and W. T. Hutchins were introduced in iglo by Messrs. Burpee and Morse.

The I9I I introductions include Dainty Spencer, Ethel Roosevelt, Rose de Barri, Purple Prince Spencer, America Spencer, and Emily Eckford Spencer.

Truly a long list. Among them are some of the finest varieties of sweet peas yet introduced, which indicates that the American growers can equal those of any country in the world. The cupid, or dwarf, pea, the bush and the winter-flowering types, all distinct in habits of growth, were first discovered on this side of the Atlantic. Since the introduction of Countess Spencer many excellent varieties of waved form have been developed, and this work of crossing and selecting is going steadily forward. Judging from the record made by the very small number of American breeders, what would America accomplish if she had even one half the number of English producers!

\section{EVOLLTION}

During the first one hundred years of the history of the sweet pea, only three varieties, or colors, were known - purple with blue wings, pale red with white wings (Painted Lady), and white. The black and the scarlet appeared in the last years of the eighteenth century. It is quite probable that the scarlet was very far from what we to-day conceive that a scarlet sweet pea should be. In Martyn's edition of Miller's Gardeners Dictionary, $\mathrm{I}_{\mathrm{S}} \mathrm{7}$, we find the white, the Old Painted Lady, the New Painted Lady (the latter with a rose-colored standard and pale rose wings), the Old Purple, and a varicty having a violet keel and wings and a purple standard. Sayers describes the scarlet sweet pea as Lathyrus flore rosea, while the Painted Lady is described as "fleshed " color. From this it may be concluded that the New Painted Lady, a rose-colored variety, was sometimes called scarlet.

The first of the striped varieties was offered in $r 8_{37}$, and since that date this group has been augmented until the classification now includes Striped and Flaked (red and rose, purple and blue). This classification, however, does not express the real range of color in this group, for we have crimson stripes, as in America; red and rose stripes on white, in Aurora; red and rose stripes on primrose, in Jessie Cuthbertson; mauve stripes, in Gaiety; blue stripes, in Prince Olaf and Hester; maroon-flaked, as in Senator. The American growers have introduced the majority of the best varieties of this group, among which are America, Aurora, Columbia, Daybreak, Grey Friar, Juanita, Pink Friar, Ramona, and Wawona. Many of these are now procurable in the waved form. 
The variety Blue Edged, the probable forerunner of the picotee forms, appeared in is6o. This was a white variety with a well-defined blue edge, a possible hybrid between $L$. Magellanicus and a white variety of $L$. odoratus. The variety, at all erents, was the first to exhibit a distinct blue color among sweet peas. Later it was known as Blue Hybrid, under which name it won an award from the Royal Horticultural Socicty. Sutton $\&$ Son sent out Butterfly* in ${ }_{1} S_{7} \&$, which somewhat resembled Blue Edged. The so-called "blues" that followed were Invincible Blue, Nadame Carnot or Imperial Blue, and Captain of the Blues, all of which had considerable red in the standard. It was not until I 899 that a good blue appeared, in Navy Blue (Lord Nelson).

The first of the soft pink varieties was Crown Princess of Prussia, I868-1869. Isa Eckford, Peach Blossom, and Lovely are the improved varieties of this color.

The efforts of the breeders of sweet peas have not all been directed toward the development of new shades of color; the form of the flower, also, has received attention. The earliest representations of sweet pea flowers show a loose, irregular bloom, with the edges of the standard turned back, that is, reflexed. Often, if not always, the standard had a notch in the apex and frequently in the margin. The standard, which is the principal part of the flower, has been improred in substance and the notches have been eliminated. The old type had a narrow base, and with the improvement noted has come a filling-out of the lower edges of the standard so that the outline approaches a circle.

In the efforts to produce varieties of the best expanded, or open, form, many beautiful hooded varieties were originated. While this fom was condemned as inartistic by many sweet pea specialists, it nerertheless received a permanent place. Prima Donna, Lovely, and Countess of Radnor are of this form.

When many persons had reached the conclusion that no further advances in either form or size were to be expected, and that the efforts of future breeders would be directed toward securing new colors and more flowers on a stem, Nature demonstrated that she had other surprises in store. In 1 øo I the Countess Spencer variety was exhibited and caused a considerable sensation. The National Sweet Pea Society awarded it the highest honors. This variety was distinct from all preceding introluctions because the standards and wings were waved. The flowers were very large and were borne in fours on stout stems. The variety was introduced in 1904 .

The parentage of this varicty has been given as (Lovely $\mathrm{x}$ Triumph 1898) x Prima Domna 1899 . However, there appeared in 1905 a variety

\footnotetext{
* Sec color plate in The Garden, $13(1878)$, p. 4.
} 


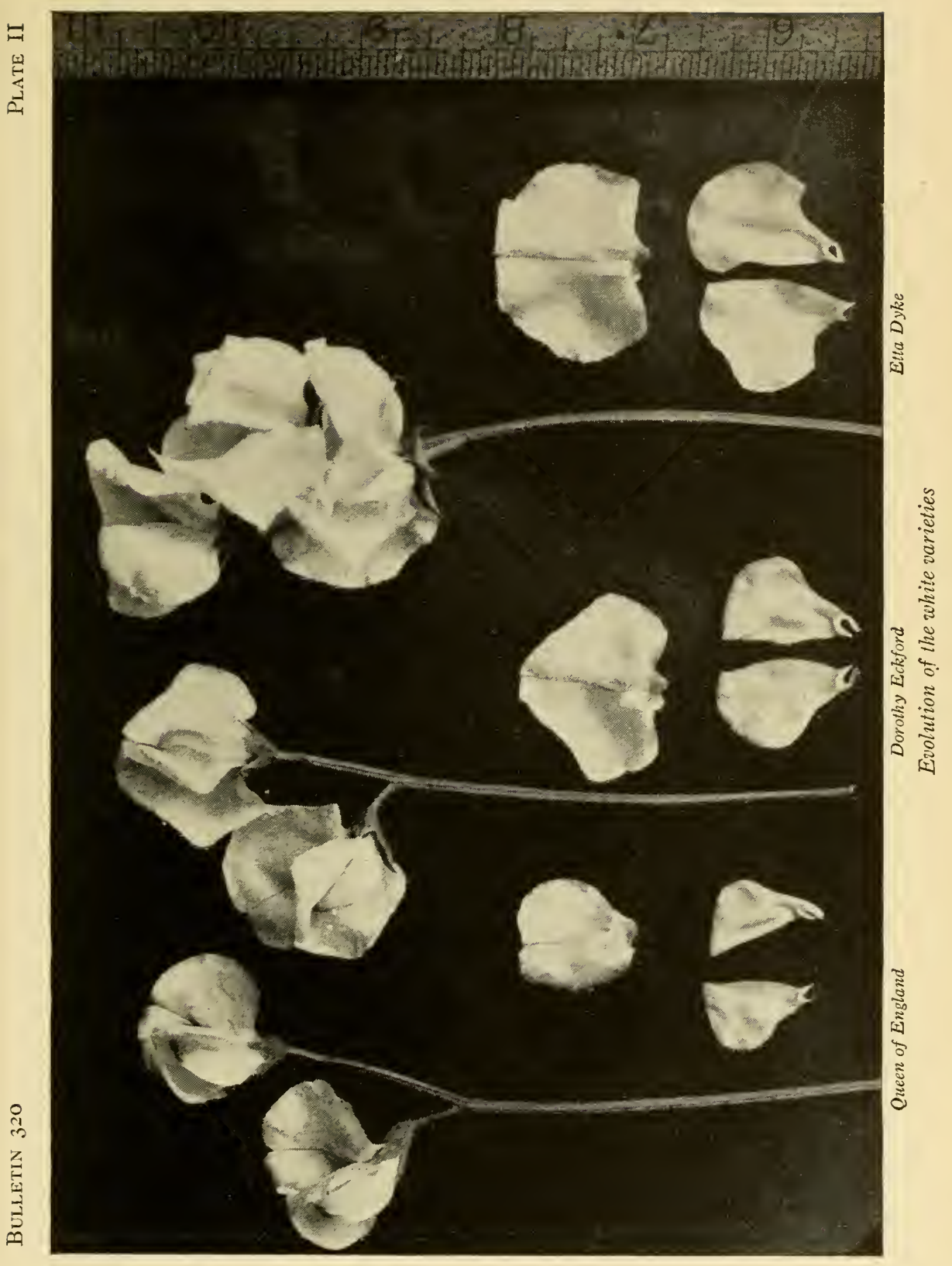



named Gladys Unwin, which has the same color but is smaller and less waved than Countess Spencer and which was a selcetion from Prima Donna without known crossing having been effected. These varieties, however, were forerunners of the new type which revolutionized sweet pea culture in England and has revived and quickened the interest in America.

\section{POLLINATION}

We have previously noted that the pistil and stamens are enclosed by the partial coalescing of the two lower petals. A very slight pressure on the base of the keel will cause the pistil to appear suddenly in the tip of the keel; the stigmatic surface is usually covered with pollen. At the same time the stamens appear to view. If the pressure is released these organs disappear as suddenly from view.

Those who are looking for flower adaptations for the promotion of cross-fertilization would say at once that here we have a mechanism that is operated by the weight of a bee alighting on the keel; the pistil and stamens rise up, striking the bee on the body and receiving and giving pollen. Thus, as the insect visits flower after flower, natural cross-fertilization is brought about.

This, however, is not the case. In the first place, if we examine flowers in the bud stage we find the pollen ripe. The position and condition of the stigma change, for before the maturation of the pollen the stigma is below the anthers. A day or two later the stigma has risen to a position among the anthers and is viscid enough to hold the pollen grains. In another day or two it has grown beyond the anthers. Self-fertilization has taken place and the development of the legume has begun. This process has taken place before the flower is fully open. Sometime later the pistil is pushed out of the protecting keel by the developing pod.

Such is the normal fertilization of sweet peas, as observed on examination of the flowers. Attention has been called to the fact that the sweet pea stood practically still for one hundred years, and the question has been asked how this can be reconciled with natural cross-fertilization.

During the writer's experience in the field each season for three months studying varieties and rccording observations, not a single instance occurred of a bee alighting on the keel of the flower, nor were any bees observed crawling between the wings. All the bees observed visiting the flowers alighted on the outside of the wings and, in practically every case, thrust the proboscis down between the right wing and the standard. In this connection it may be mentioned that the bees did not show a preference for any particular color, but flew from row to row and from color section to color section. 
T. H. Dipnall has observed that bees attack sweet pea flowers. The lee (a yellow-and-white-banded species) alights on the calyx, crawls around it to a certain position, and cuts a hole through the calyx so that it can thrust its proboscis through and suck the nectar at the base of the pod. The reason is not clear why the insect prefers one side of the flower, since the structure is similar on both sides.

It is to be remembered in this discussion that sweet peas under glass in winter are not visited by bees, but every flower will set seed in sumn weather if the blooms are not kept cut.

Since the introduction of the waved type there has been much discussion about the difficulty in fixing varieties and the reasons for it. Some growers, having secured what was to all indications a fixed stock, have discovered, after sending it out, that it was not fixed. Some of these growers thought that this occurred only when the novelty was sent to California for working up a large stock of seed, or after it had passed into the hands of the California growers. One of the theories advanced to explain this was that a certain insect in California was responsible for some cross-pollination of flowers. In the trials at this station during the past season no difference was observed between English or American-grown stock, since we had seeds of novelties direct from the originators and our varieties were from the introducers.

Other growers say that bees visit the flowers, and they believe that crossing takes place in the waved type, which, it is maintained, does not produce normal flowers in that the pistil sometimes projects beyond the keel. It appears that, if this view is correct, the poor seedling of the waved type would not occur, or at least that the worse the fault of the flowers, the greater the erop of seed. Thus, the varieties that seeded freely would become cheap and drive out the others. The writer thinks that the results obtained by the seed growers contradict the theory. It appears that the poor setting of seed may be due to the fact that the pistil may grow out beyond the anthers before the latter are mature, and thus fertilization can be prevented by irregular development of the parts; otherwise, the pollen may be impotent in some varieties, but this does not occur so far as the writer has studied the reports of the sweet pea brecders. The writer did not observe any pistils showing the defect mentioned, but as the season here was very dry the plants did not make an exceptional growth which would be likely to express itself in abnormal flowers exhibiting the pistil. However, it was observed that some varieties seeded more freely than others. Most of the varieties were planted here in $191 \mathrm{I}$ from soeds saved in rgro and, knowing those that were fixed the previous year as well as those with rogtes of certain colors, it is thought that some light may come on this matter of cross-fertilization, if there be any, in the sweet pea. 
The dwarf, or cupid, sweet peas are varieties that grow only five to eight inches high, with a spread of twelve to fifteen inches in diameter. The procumbent stems are stout, vigorous, short, jointed, and freely branching. The foliage is a deep green. The leaflets are small and the tendrils short. The flowers, which are of the size of those of the tall varicties, are borne, two or three in number, on short stems three or four inches in length.

The dwarfing has been accomplished by an extreme reduction in length of the internodes, for an examination of the plants reveals the fact that they have as many internodes as, or more than, the tall type.

The cupid sweet peas originated in 1893 at Santa Clara, Cal., on the grounds of C. C. Morse \& Co., the largest growers of sweet pea seed. The plant was found growing among plants of the tall-growing variety, Emily Henderson. Naturally, this remarkable sport was preserved and its dwarf character proved to be so fixed that it is recorded that when Messrs. Morse grew seven acres of this novelty, in 1895 , none of the plants reverted to the normal climbing type.

W. Atlee Burpee purchased the variety in 1894 and had it grown in England by James Douglas, where in June, 1895 , it was exhibited before the Royal Horticultural Society and was given, by unanimous vote of the committee, an award of merit. The same year it was given an award of merit by the National Horticultural Society of France.

In Burpee's circular to the trade, July, I895, this white-flowered variety was described It is a singular fact that but for this trade announcement a similar dwarf form would have been offered by Ernest Benary, of Erfurt, Germany, in 1896 or 1897 , probably under the name of Tom Thumb White. It was such a complete description of his variety that the similarity was recognized and Mr. Benary published in his catalog the name of his novelty as a synonym of Cupid, thus preventing confusion.

In 1895 a similar dwarf appeared on the grounds of Henry Eckford at Wem, England. There is also some evidence that a similar form was found in I895 among plants of the Old White grown in southern France.

This remarkable instance of synchronistic variation appeared in three or four widely separated localities within a period of two years. Singularly cnough, so far as known, all these dwarfs had white flowers and white secds and developed among white varieties.*

This novelty attracted considerable attention everywhere, especially among sweet pea lovers, and was offered to the public in I896. Unfortunately Cupid, afterward known as White Cupid, the forerunner of

* A notable and somewhat similar case was the appearance of the dwarf lima beans, but here we find the origin extending over a period of twenty years and the varieties are simultaneous only in the date of introduction. Moreover. we have very distinct varieties originating from very distinct climbing varieties of lima beans of two species. 
the race, was white-seeded like the parent and germinated very poorly, esplecially the year of its introduction. It appears that even among white-seeded peas this is probably the most sensitive to unfavorable conditions during germination.

Pink Cupid was discovered among plants of Blanche Ferry in 1895 and was introduced by Burpee in 1898 . Burpee had purchased the stock of I, o6S seeds, for which he reported paying the sum of $\$$ I, 500-probably the largest sum ever paid for a new variety of sweet peas. This variety was similar to Blanche Ferry in all characteristics except its dwarf labit.

A yellow sport found among White Cupid was introduced by Burpec in 1899 as Primrose Cupid.

During the seven years following the introduction of the original Cupid sweet pea a great number of varicties appeared, reproducing all the known colors and types of the tall-growing varieties. "Several of our best Cupids," says Morse, "were found originally in the tall varieties but the majority were developed by crossing." *

Laxton Brothers, of Bedford, England, began crossing upon Cupid soon after its introduction, and at the bicentenary celebration in 1900 it was reported that this firm had dwarf comnterparts of Purple, Dark Bluc Striped, Captain Clarke, Rose, Light Blue Striped, Invincible Blue, Invincible Carmine, Invincible Red, Invincible Black, Sultan, Rising Sun, Borcatton, Princess Beatrice, Princess May, Princess of Wales, Etna, Vesuvius, Indigo King, Pale Nadame Carnot, Waverly, Primrose, Carmine Striped, and Comntess of Radnor.

It will be noticed that many of these were representatives of tall varicties that were obsolete or were passing out, and of course were not equal to such varieties of Cupicl as Beauty, Alice Eckford, and Firefly, which had been introduced by that time.

\section{Trarietics of cupid sweet peas}

White, or "Cupid," I 896

Pink, 1898

Alice Eckford, i 899

Bcauty, ı 899. Similar to Eliza Eckford

Primrose, 1899

Boreatton, i 900

Countess of Radnor, 1900

Firefly, I 900

Apple Blossom, I 90 I

* Waldo E. Rohnert reports the results of crossing the tall varicties upon the Cupid swcet pea in Bulletin 127 (1897), Cornell University Agricultural Experiment Station. 


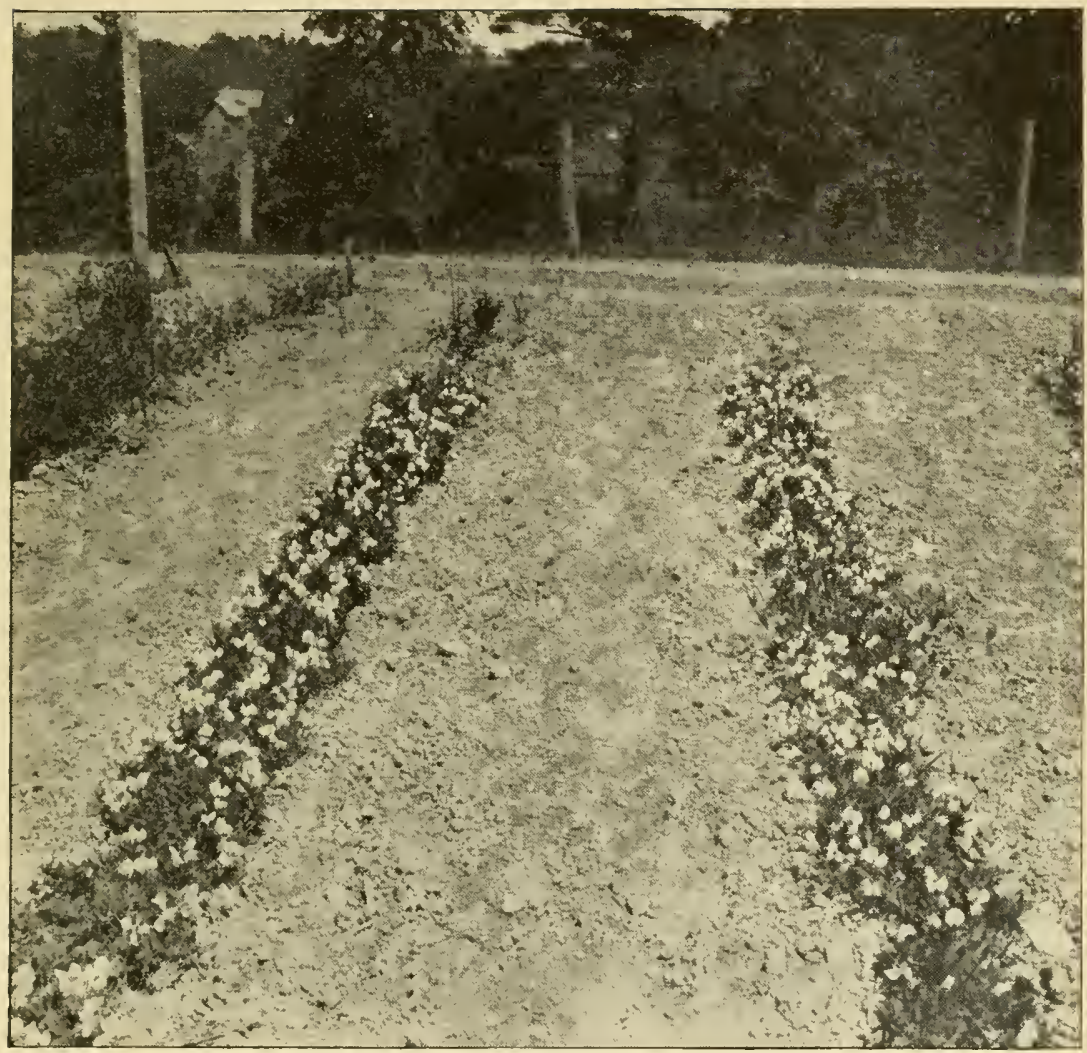

Dwarf sweet peas 

Captain of the Blues, I90I

Chamberlain, I901. Similar to Mrs. Joseph Chamberlain

Royalty, г9or. A dark Royal Rose

Stella Morse, I90I

America, 1902

Her Majesty, I 902

Lottie Eckford, 1902

Bridesmaid, I 903

Enchantress, i 903 . A dark Lovely

Mauve Queen, I90.3

Extra Early Blanche Ferry, 1903

Sadie Burpee, 1903

Lady Mary Currie, I904

Prima Donna, I904

Prince of Wales, 1904

Salopian, I904

Emily Eckford

Lovely

Navy Blue

Waverly

Orid

Ramona

\section{Unpopularity of the type}

The cupid sweet peas have never been very popular for several reasons. Many persons apparently expected this dwarf type to furnish long-stemmed blossoms for cutting, thus relieving them of the necessity of providing supports for the plants. The short stems of this type were therefore a disappointment to such persons and they unhesitatingly condemned it for any purpose. In answer to the claims made that the plant was adapted for use as an edging or for bedding, it was urged that the blooming period was too short- not allowing for the fact that the dwarf type behaves similarly to the tall type and ceases to bloom if the pods are not removed. For no other reason this sweet pea has been ignored by many seedsmen, while some inferior trailing plants are still offered in their catalogs. The dwarf sweet pea has the advantage of many border plants in its great variety of colors.

In part the unpopularity of the plant has been due to the fact that the White Cupid did not germinate very successfully, especially the first year of its introduction, thus affecting the popularity of this whole race. The black-seeded varieties give a high percentage of germination, so that poor germination is not an inherent fault of the race. 
The dense foliage and growth of the plants make a thick carpet over the surface of the ground, and in a wet season the result is usually failure. The flower buds drop off and the plants do not thrive even if they do not become subject to disease. The foregoing reasons explain why this type has not been very successful in English gardens.

In California, where the summers are long and dry, the cupid sweet peas thrive. During hot, dry summers in the Eastern States, when the tall varieties are subjected to very trying conditions, the cupid sweet peas grow and bloom abundantly. In 19 10, ten 20 -foot rows of different varicties of the dwarf type were grown at this station. When the tall kinds were having a struggle with the drought under a temperature of ninety degrees or more, the cupids, in the highest and driest position in the field, grew and blossomed profusely. They were admired by all who saw them and many questions were asked as to what they were, whether they were of recent introduction (new), and where they could be obtained.

The conditions necessary for the successful culture of the dwarf sweet peas appear to be a rather dry, moderately rich soil, a dry, hot season, good cultivation, and prompt removal of the withered flowers and pods. The seed may be sown in single rows, twin rows, or scattered in a broad drill ten or twelve inches in width. For the purposes mentioned the distinct colors are preferred. Among the best varieties are White, Pink (Blanche Ferry Cupid), Countess of Radnor, and Prima Donna.

\section{GARDEN CULTLRE OF THE SWEET PEA}

\section{The soil}

Site.-An open, sunny location should be chosen, so as to provide plenty of light and air. Plants grown in too shady a position are weak and spindling in growth, producing few flowers. A little shade from the scorching, midday suns of July and August is desirable, especially for preserving certain colors.

Any ordinary garden soil is suitable for sweet peas, provided it is suficiently drained so that in periods of excessive rains the water will not lie on the surface, eausing the plants to become yellow and the roots to decay, or starting mildew. Soil suitable for the growing of vegetables will give fairly good results, but extra care in the selection and preparation of the soil will be repaid in larger flowers, longer stems, better colors, and a longer blooming period.

Preparation.- The sweet pea is a deep-rooting plant, and in order to provide suitable conditions so that the effects of drought are overcome the preparation must be deep and thorough. 
Whatever the soil, unquestionably the best preparation is made by trenching the soil in the autumn.* When, owing to expense, the soil cannot be completely trenched, practically the same result may be accomplished by digging a trench fifteen inches wide for each row. The soil should be broken up to a depth of fifteen inches to two feet, and on some soils even deeper. Unless the soil is very uniform in composition, it is disastrous to bring the bottom soil to the surface; but this should be turned over in the trench, mixing with it, if heavy and compact, rather coarse stable manure or litter. Sometimes leaves are available for placing in the bottom of the trench. The use of these materials in subsoil promotes drainage, as well as improves the soil.

If a good layer (four inches) of half-rotted stable or cow manure is placed between the top and bottom spadefuls, and the top soil, if heavy, made light with old manure, an excellent preparation has been made. The office of the manure is not only to increase the store of plant food, but also to increase the water-holding power.

Bone meal, applied at the rate of one ounce per yard of trench, is essential.

A good dusting of air-slaked lime applied while working the soil in the autumn is very beneficial. Many soils that have been cultivated for a long time are acid, so that leguminous plants, such as clover or sweet peas, will not grow, or, at least, do not thrive. Lime corrects this acid condition and, furthermore, it releases plant food that would not otherwise be available in soils which are not acid. Clay soils are made more open and porous by the use of lime.

Deep preparation not only promotes available fertility, but also increases the area in which moisture and nourishment may be found, and the plant responds by sending feeding roots in all directions.

While it must not be inferred that sweet peas can be grown only in deeply trenched and prepared soils, it is true that only under exceptional conditions are the results satisfactory when this is not done. Uniformly, year after year, the sweet peas with the strongest root systems will produce the finest flowers during the longest period.

\section{The seed}

Some white-flowered varieties have white or light-colored seeds, and some have black seeds. The white seeds often give trouble by rotting in the soil - especially if planted early when the soil is cold - or because their germinating power has been impaired; also they frequently split in the pod before harvesting and in this condition are likely soon to lose

\footnotetext{
* The texture of clay soils is sensibly altered when fall-plowed or stirred and exposed to the action of
} frost. 
their vitality. For the foregroing reasons it is advisable to sow seeds of this color rather thicker than, or not so deep as, the black-seeded varieties.

In some seasons, sweet pea seeds are slow in germinating. It is well to examine such seeds in order to ascertain their condition. If the seeds are found dormant but still fresh and plump, the seed coats should be cut with a sharp knife and replanted, when they will germinate well. This difficulty is not confined to the sweet pea, but some of the other Lathyri behave similarly. The trouble usually follows a very hot, dry season, when the seed becomes so excessively ripened as to render the seed coat impervious to water. Sometimes, in order to expedite germination, the seeds are soaked; a better method for the amateur is that recommended by Mr. Hutchins, the most prolific writer on sweet peas in America, who places the seed packets in moist earth for seven or eight days, then takes them out and examines them. The swollen seeds are planted and the others cut with a knife.

\section{Planting}

Fall planting.- In the season under discussion, the finest and the earliest flowers were secured from plantings made in the fall. The preparation of the soil is the same as that already described, except that the soil is firmed and the trench filled level. On this a trench, or furrow, two inches deep is made, and the peas are planted at least as close as one seed every two inches. The row should be slightly ridged up so as to prevent water from standing and, as stated in the beginning, it is essential that the location be on a well-drained site. When the ground freezes, a mulch of manure is placed over the row. In the spring when the bright weather comes, the plants should be examined in order to see whether they are growing or whether the soil is soggy and cold. In either case, the mulch should be removed from over the row, and should be left in the center so that, in case any weather should come when the safety of the plants is at all endangered, the old mulch may easily be applied to protect them.

The seed of the standard varieties of sweet peas is cheap, and the advantage gained in obtaining carly flowers, if the plants survive the winter, is worth the effort.

Spring planting.- As soon as the frost is out of the ground and the soil in workable condition in the spring, a heavy application of superphosphate of lime should be made and raked in. Care should be exereised not to get the soil too loose, and for this reason it is best to confine all stirring of the soil to smoothing the surface. Especially is this true with light soils, which, if stirred deeply in the spring, must be well firmed. Heary soils that are likely to bake may be improved by working in a light dressing of old, thoroughly rotted manure. 
Sweet peas should be sown just as early in the spring as the soil is dry enough to work, even though it be certain that heavy frosts may follow.

The writer thinks that one reason why even the most inexperienced amateur usually has so good average results with sweet peas, is that when this individual gets his annual "violent attack of gardening fever" in early spring, he begins his operations at just the right time for sweet peas to go into the ground.

An essential requirement in growing sweet peas is to plant early, while the atmospheric conditions are such as to prevent top growth unil the plant has started a vigorous root development. The result is that, when warmer weather comes, the top grows strong and heavy, the plant branches out, and throughout the season this increased vigor is seen. Experiments made by sowing seeds every ten days from the earliest practicable date until the end of May show this result conclusively.

Depth.- If the preparation of the soil has been made in the fall, it is best only to smooth the surface of the trench and plant in this. When the preparation has been made in the spring the soil must not be left too loose - a condition that may easily occur if a deep trench is made and only loosely filled with soil and manure.

One method recommended is to hollow out a broad trench, twentyfour to thirty inches wide and two inches deep, and then sow the seed one inch deep in single or double rows. The trench should be kept open for six weeks in order to retain the water. This system is very good in a garden where all cultivation is given by hand; but where many rows are grown and cultivation is done with a horse and cultivator, it is manifestly impossible to make or to maintain such a trench. Furthermore, when horse cultivation is to be used there would be difficulty in keeping the young plants, if planted below the surface, from being covered during the early cultivations. Therefore, planting on the level is necessary in field culture. It is advisable, however, in garden culture, to plant so that when covered the row will be two inches below the ordinary level.

Shall the planting be in single drills, broad drills, or double rows or drills? It matters little, provided sufficient room is allowed for the growing plants.

Amount of seed.- The latest American book advises sowing one ounce of seed to a fifteen-foot row, and later thinning the plants to six inches apart. Now let us see what this means. Since an ounce of seed contains three hundred to three hundred and sixty seeds, if in a single drill the seeds will be three fifths to one half inch arart. If only seventy-five per cent of the seed grew (which is a very low estimate), one hundred and ninety-five to two hundred and forty of the seedings must be removed in thinning to the distance given. In other words, the author of the 
above-mentioned book advises planting ten to twelve seeds in order to get one plant, or leaving about ten per cent of the seed to grow. In the plantings at this station, one hundred seeds, except when doubtful, were sown to a twenty-foot row, or one seed every two inches, and this is heary seeding. Under the latter system an ounce will plant fifty to sixty feet of row and, if the seed is good, it should plant still more.

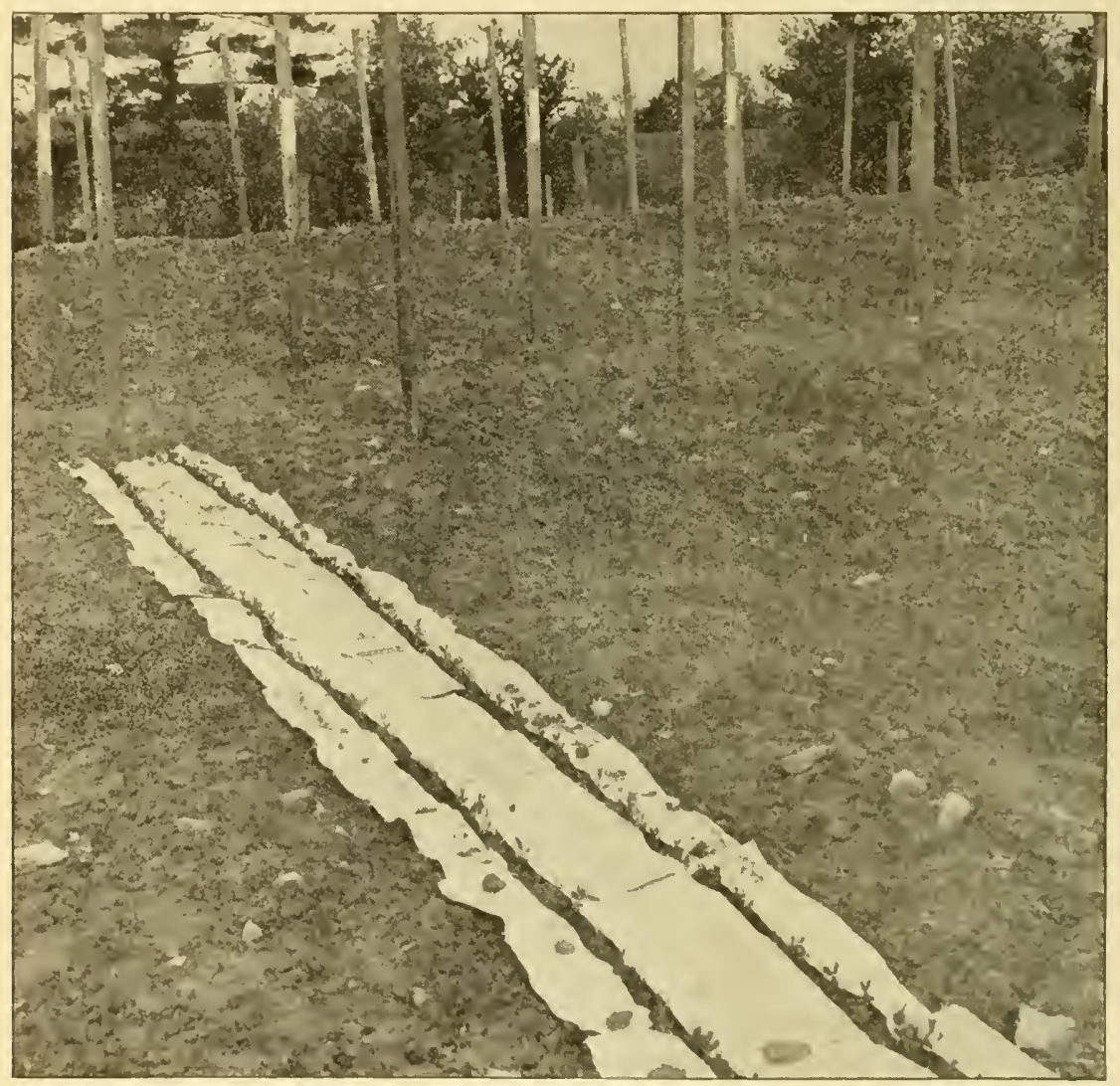

FiG. 184.- The double-row method of planting

Sowing $2 n$ pots for outdoor bloom.- Many English growers practice sowing in pots under glass, hardening the plants in frames, and planting out. From the writer's experience with three varieties during the year under discussion, he is inclined to look on this method with faror, especially. in growing high-priced novelties or varieties for exhibition. In fact, if the results of experience and observation at this station in I) Io are to be 
relied on, it would appear that the successful exhibitors of the future will obtain their flowers from fall-sown or pot-grown plants.

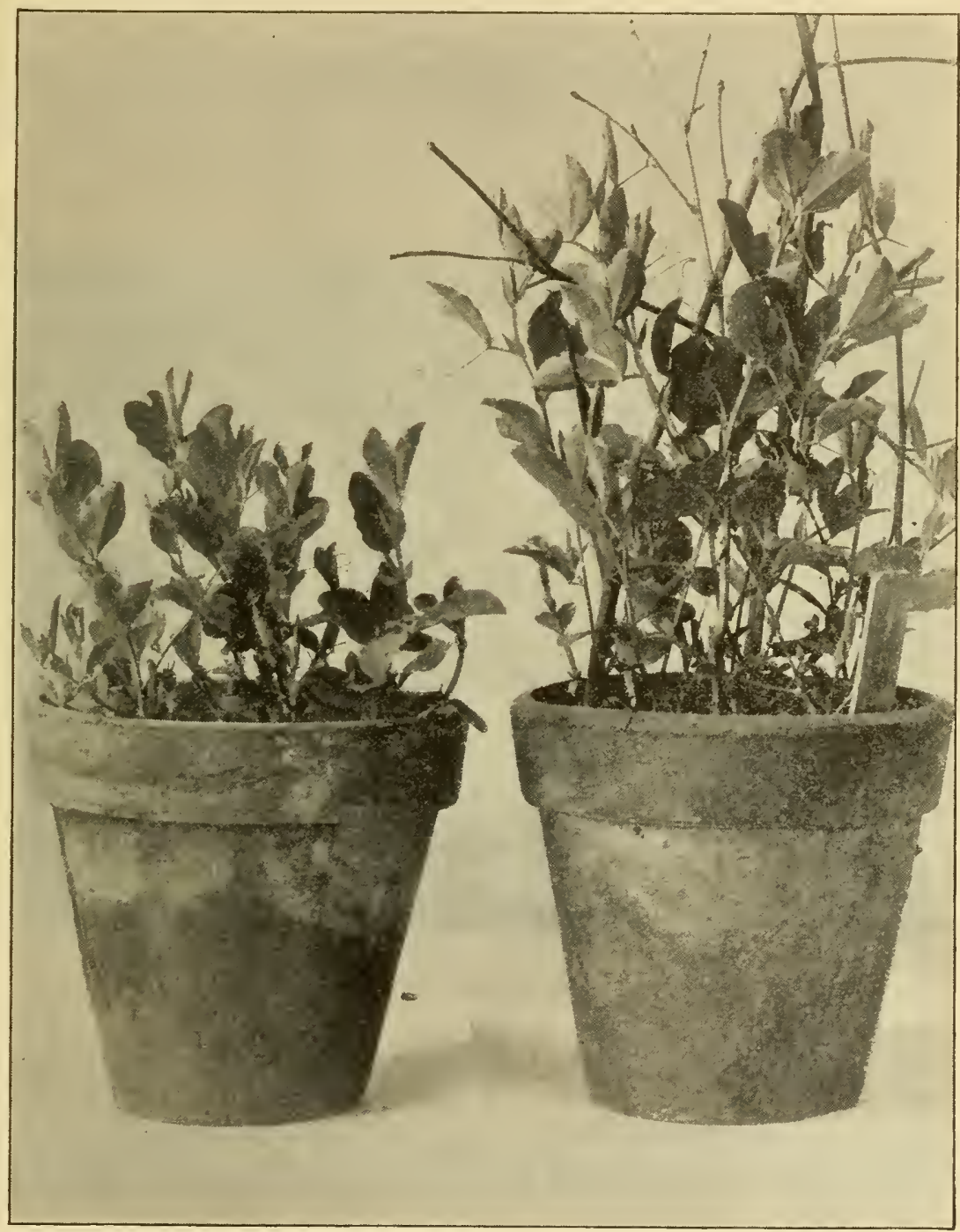

FIG. 185. - Sweet peas started in pots

In order to secure suitable plants, six seeds should be sown in fourinch pots, using light, rich soil. The best time to sow sweet peas in this manner is in March. When the plants are two or three inches high they 
should be given supports of short twigs and placed in a cold frame. Here they should be given plenty of air at every opportunity, in order to secure a short, sturdy growth. If the plants do not catch hold firmly, they may be ticd with raffia. When spring begins and the soil is in good condition, the pots may be planted in the open, one foot apart in a single row or two fect apart in a double row. In the latter case, the plants alternate as shown below:

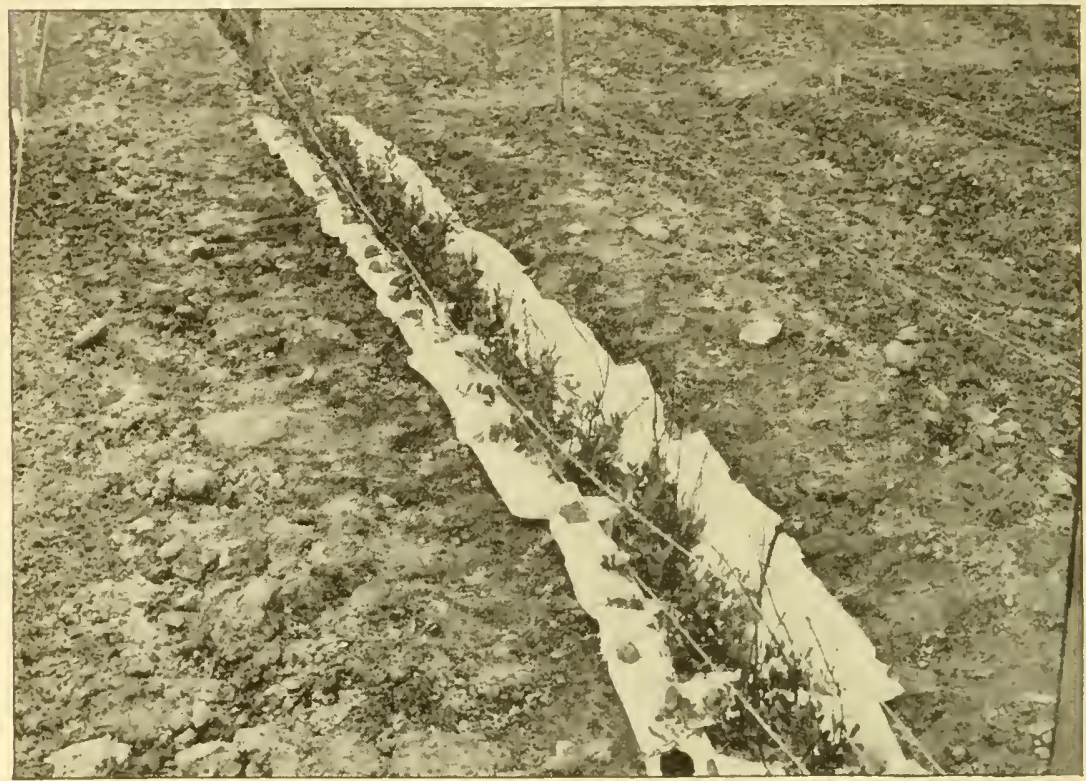

FIG. 186.- Sweet peas transplanted from pots

\section{Sipports}

Sticks. - Among English sweet pea growers there is considerable unanimity of opinion that sticks form the best support for sweet peas. 'The replies of fifty-two leading experts, published in the Sweet Pea Annual for 1907 , show that forty-three growers favor sticks (generally hazel sticks), five favor wire netting, two favor either sticks or wire netting and, if the netting is new, paint it - one prefers sticks and string, and the remaining one, a correspondent from British Columbia, uses telephone wire and string.

In this country, where good twiggy boughs can be obtained, such boughs unquestionably form the best support to use since they are the most natural. 
In many places birches can be obtained in lengths of twelve to fourteen feet. These may be prepared in the lengths desired.

How tall should the support be? The grower is the one to determine that. If the soil has been prepared properly and the plants look strong, and if the grower sees that the plants are watered and given every care, then the support should be six feet high. If the soil is only moderately fertile or has not been deeply prepared, or if the grower does not intend to keep all seed pods picked off or cannot water the plants in order to overcome drought, the support should be kept down to four feet. The variety has something to do with the height of the support, whatever the care bestowed, some varieties being naturally dwarfer growers.

The sticks should be cut in late winter or very early spring, so that they are still rather green and tough enough to bear the load until the end of the season. They should be inserted in the soil at least a foot, because when clothed with vines to a height of six feet a strong windstorm exerts a tremendous leverage on them. Unless the sticks have been inserted deeply, or if they have become too dead and brittle, the row will go down under the force of the wind and the great weight of the wet vines. In order to guard against disaster, strong stakes are sometimes placed every ten feet and wire is run lengthwise through the sticks and fastened to the stakes. It is desirable to have the sticks bushy at the top, so that they spread out more than at the base; if not naturally so, leaning the sticks alternately outward will produce this result. This gives greater freedom for the vines when in flower.

After the sticks are inserted, a better effect is produced if the tops are clipped to a level and straggling ends are cut back. If the sticks are not "feathered " sufficiently at the base for the plants to get started up on them, the clippings from the tops may be inserted between the tall sticks. Some growrers make a practice - and it is a good one-of providing a light support when the plants are one to three inches high, and later placing the tall sticks. For the light support they often use old raspberry canes or the old stems of our wild aster - in fact, anything of a light, much branching character. This affords protection from high winds when the plants are small.

Netting. - When other systems of supporting are to be employed it is quite imperative to provide a support of small, short twigs as soon as the seedlings begin to produce tendrils. This method prevents the rain from beating the small plants down, and enables them to get up to the other support. In city gardens, owing to the difficulty in procuring suitable sticks, wire netting makes a very satisfactory support. The peas do not cling to it so well but it is cleaner and neater in appearance, which is a compensating advantage.

The large mesh, four-inch, is pref- 
erable, but in many places this is not procurable and the ordinary chicken netting, or fence, is used instead. Strong stakes at intervals not to exceed ten feet are used to support the netting. One advantage of wire netting is that if stakes six feet high are used, a forty-two- or forty-eight-inch strip of netting may be placed in position, and, if the season or soil is favorable and the peas grow above this, a narrow strip of netting may be added or a string or wire stretched from stake to stake over the row. A well-galvanized netting can be used repeatedly for several years, and will last longer if taken off in the fall and stored.

String.- Another method is to construct a support of wire and string, or of string alone. The ingenious grower can construct all sorts of fanciful designs with wire and string on posts set not over ten feet apart. Sometimes a wooden strip is nailed horizontally at the top and bottom, but often a wire is used instead. From bottom to top, between these horizontal strips or wires, a homemade network can be made. When the peas are grown in double drills, the construction described above is made on each side in box-like form.

When sweet peas are grown in single drills especially on a considerable scalc, the best and cheapest support is one made by placing stakes at intervals under ten feet, and winding strong cord around the row from stake to stake. The strings are placed six to eight inches apart, or closcr if necessary. If the stakes are too far apart - ten fect or morethe string will stretch after becoming wet or even damp, and the plants will fall over. If appearance is not an object anything will serve for stakes, as tailings from the mills, poles, and the like. When neat stakes are driven in the row this method is very good in the garden as the vines cling to the string better than to wire netting, which becomes hot; also, the supports when string is used may be made as tall as needful for the peas. Thus there are only the tops of stakes showing above a row of short vines, in place of a row of uncovered netting. At the end of the season, if the stakes are worthless the whole support, as well as the sticks, can be burned.

Sweet peas are sometimes grown in clumps and must be supported. Here again sticks are often favored, especially where the plants occupy. a circle six or more fect in circumference. Wire netting cut in suitable lengths may be made into cylinders for clumps of any size.

Other methods.- Henry Eckford advertises a sweet pea support consisting of four stakes, each in two pieces three feet long. These are placed ninety degrees apart around a circle and three-foot netting is stretched around them. When the peas reach the top, if greater height is needed the upper half of each stake is fitted by means of a mortise into the top of the one already driven and another strip of netting is put on. 


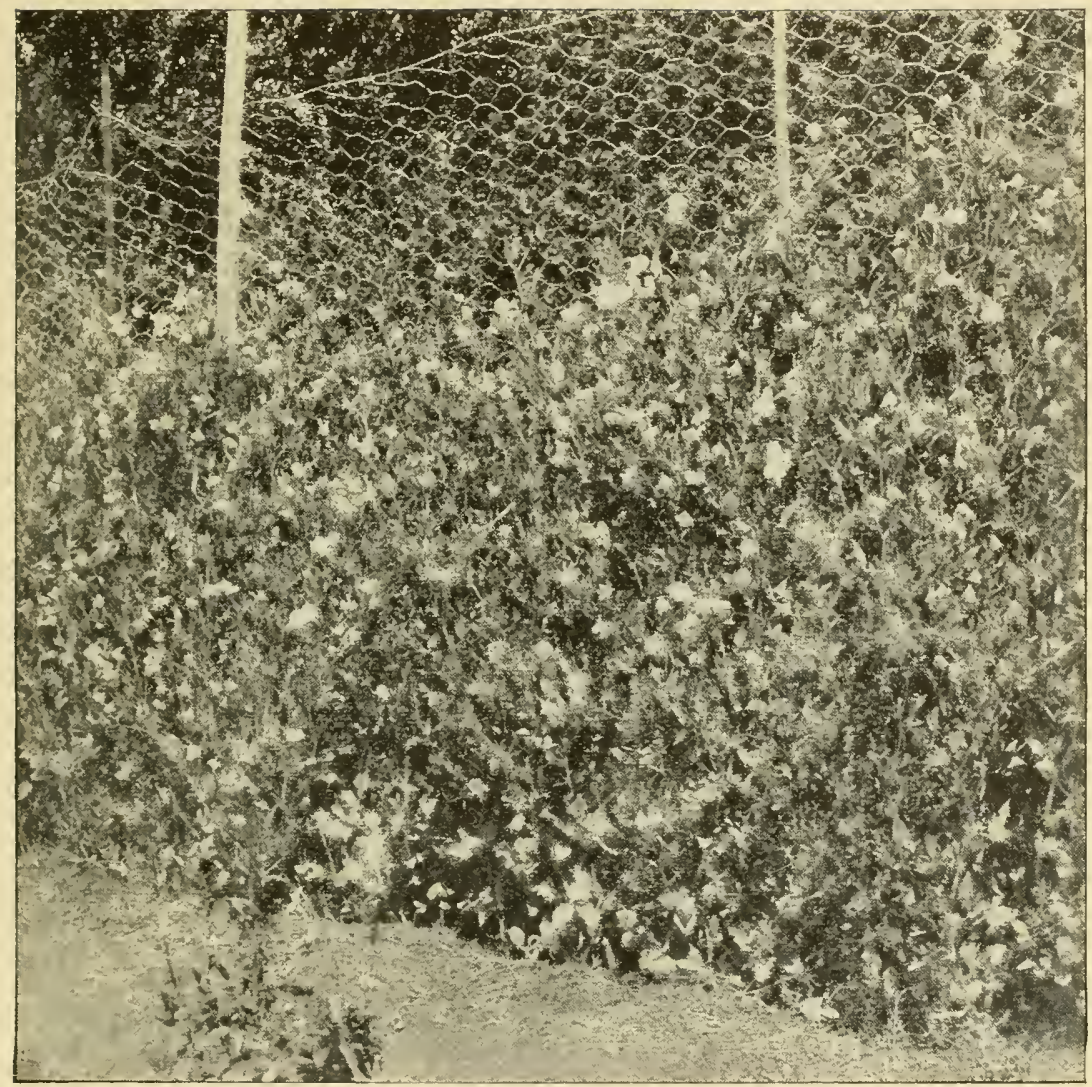

Sweet peas on wire nelling 


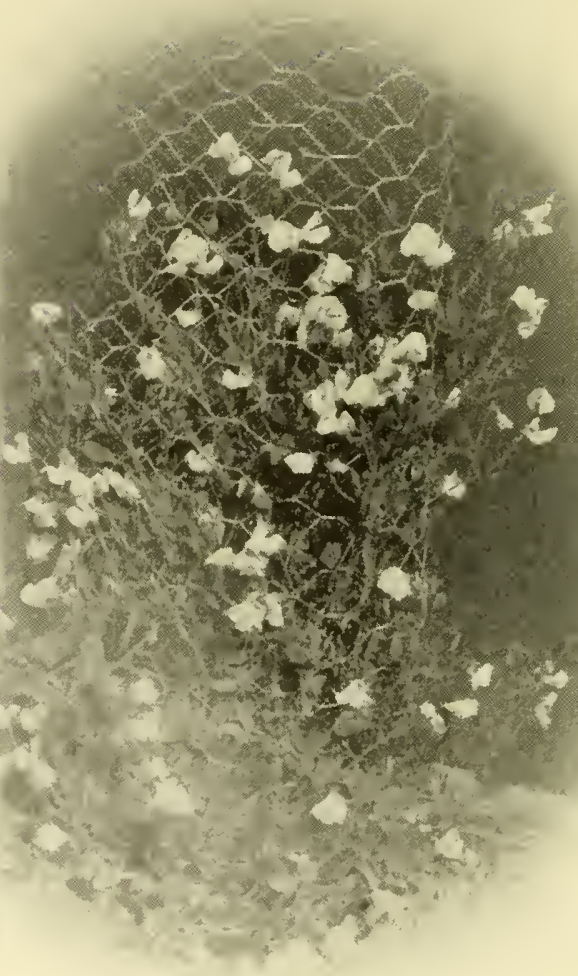

Sacet peus growh in clumps 
An English seedsman advertises sweet pea ladders for use in training the rines in garden decoration. The ladders are made six feet long and six inches wide. They are used perpendicularly, the tops being fastened to a horizontal wire. Two rows are supported by leaning the tops together and fastening them to an overhead horizontal wire. Plants grown in circles may be brought together in the center at the top, where the ladders are fastened to a center stake. Sweet pea arches are sometimes made. These, of course, should never be over six feet high or they would seldom be covered.

Now the ladders can be easily made with two No. Io galvanized wires, rose stakes of the proper length, and some smaller wire for the rungs or cross wires. The arches can also be made complete, if desired, by merely making the ladder long enough and bending it into the form of an arch.

\section{Cultivation}

Tillage, watering, and mulching.- Frequent cultivation should be the rule in growing sweet peas. A very liberal use of the hoe or the cultivator in maintaining a loose, shallow surface mulch is imperative for success. Proper preparation of the soil, coupled with such treatment, will do much to obviate the necessity of watering.

Watering should not be begun until it is absolutely necessary in order to prevent the plants from suffering. When necessary the applications should be thorough, and in very dry periods at least two or three times a week.

A mulch of thoroughly rotted manure around the plants will alone lessen the effects of drought, and will also prevent too rapid loss of water when it is applied.

Dispodding.- In order to have fine flowers and a long succession of bloom, it is infinitely more necessary to keep the seed pods rigorously picked off than it is to cultivate, mulch, or water. The latter operations go for naught unless the pods are picked off. The writer thoroughly believes that the importance of watering has been overemphasized and that too many amateurs prefer to use the hose rather than to pick pods; then they assert that the sweet pea is not what it used to be, that it has lost constitution, and the like. Of course, the more highly developed the variety, the less certain it is to bear up under neglect. There were on the trial grounds at this station in I9ro some of the oldest varieties, introduced from 1865 to 1890 , then the latest hooded and grandifloras, and finally the waved type. Although no pods were picked from the first two types after July 20 , there was a noticeable difference in the flowering habit. The old varieties were continuously blooming profusely, while the second class were sometimes completely destitute of flowers. 
The same holds true with regard to length of stem. Some plants of Countess Spencer were treated likewise in order to note the effect, and for them the season was over early in August.

The lesson is that if the grower does not intend to comply with the requirements of the improved types, it is better to grow Butterfly, Captain Clarke, Peach Blossom, and other small-flowered, precocious varieties. Fertilizers. - After sweet peas are in full flower, fertilizers may be applicd. The best and safest fertilizer to use is liquid manure, diluted to the color of weak tea and applied once a week. It is often advantagcous to alternate this with sulfate of ammonia or nitrate of soda at the rate of one ounce to six gallons of water. The plant responds better usually to phosphorus than to nitrogen, and even potash is often beneficial. Nitrate of potash and phosphate of potash dissolved at the same rate as the above-named fertilizers, is of the proper strength to apply.

\section{Summary}

The following quotation from George Stanton is a concise summary of sweet pea culture:

"Swcet Pea Culture, condensed.- I 2 words. Trench deeply; manure liberally; plant thinly; stake quickly; water freely; dispod promptly."

\section{INSECTS AND DISEASES}

\section{Insects}

The most troublesome insects that attack sweet peas in the United States are the red spider and the green plant louse.

The red spiders attack plants during hot, dry periods, when they are to be found on the underside of the leares. Usually they are not noticed until they have become sufficiently abundant to cause considerable damage. The experienced grower recognizes the farorable conditions for this insect and begins syringing the plants in the evening, applying the water with hose or spray pump so as to wet the lower surface of all the leares. This treatment will prevent serious attacks of the red spider.

The green $f_{y}$, or green plant louse, while often present under other climatic conditions, causes greater injury during weather favorable to the red spider than at other times. This insect may be killed by the use of tobacco extracts, dilute kerosene emulsion, or soap solution. Dusting the plants with tobacco is sometimes practiced.

Nematodes, or eeluorms, do not attack sweet peas planted outdoors unless infested soil from the greenhouse is used around the plants. Vithen sowing seeds in pots under glass, the proper soil is that which has been sterilized or thoroughly frozen. 


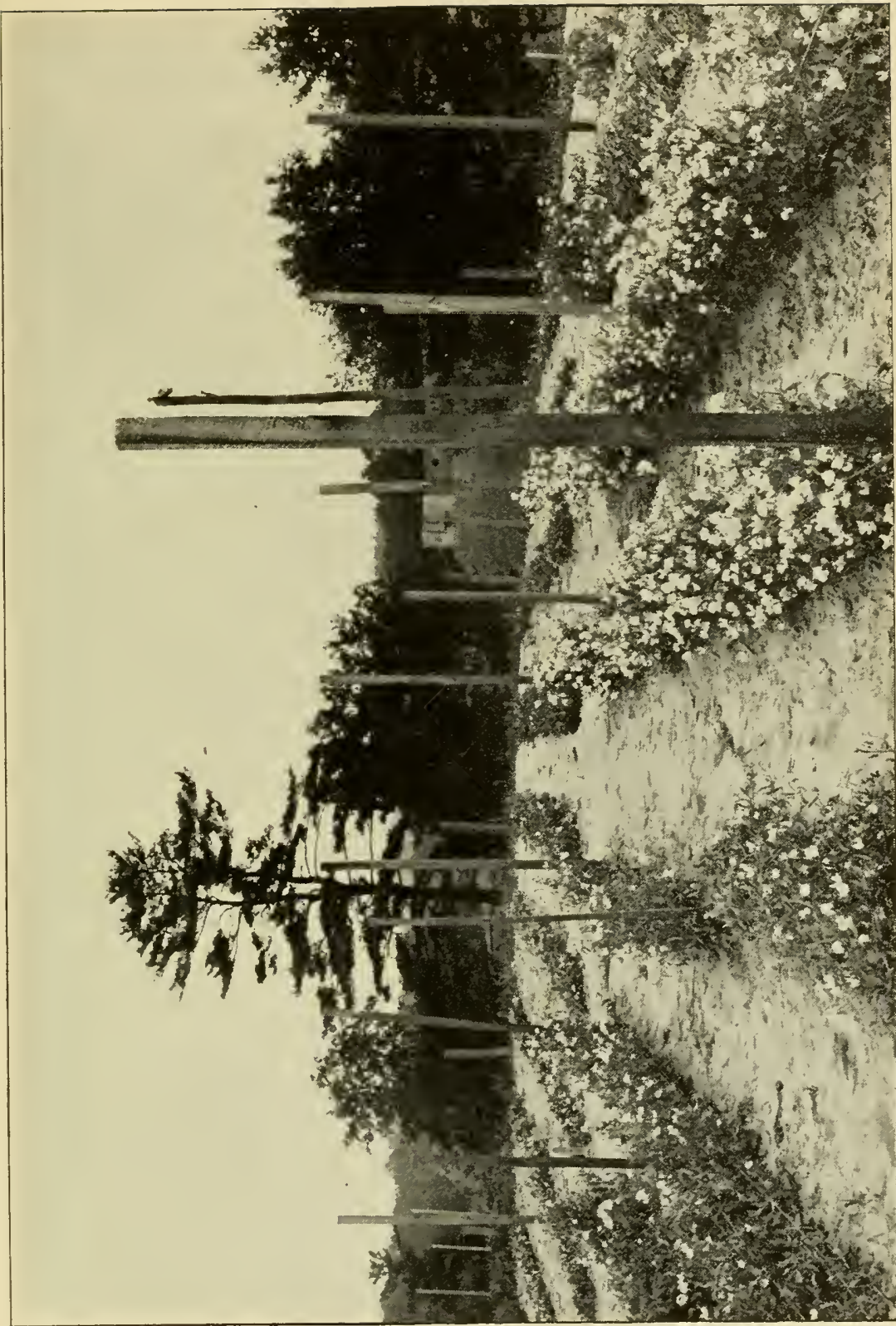




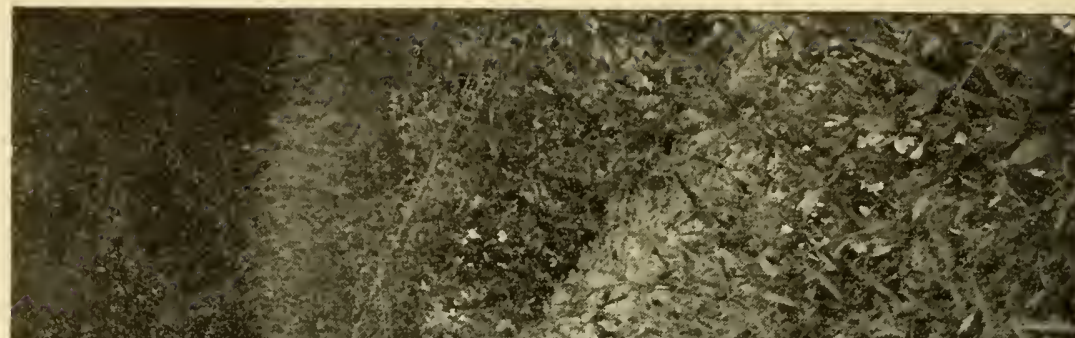

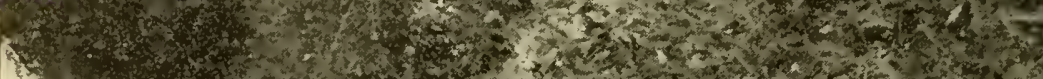

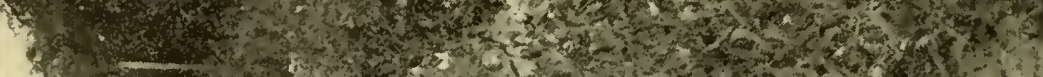

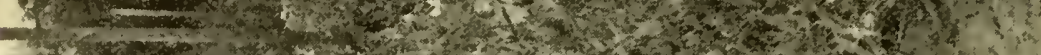

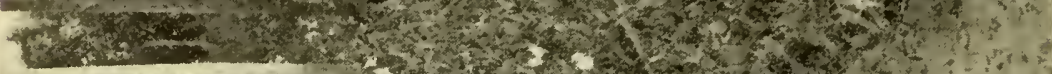

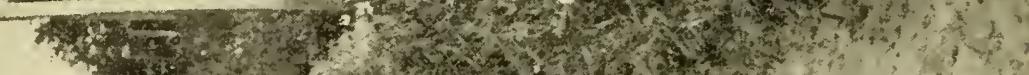

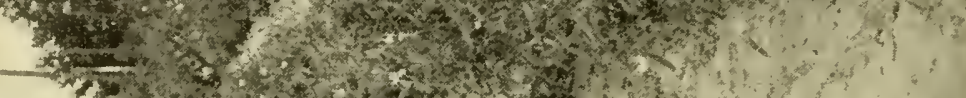

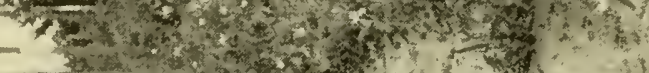

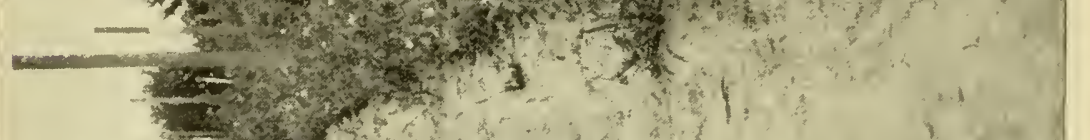

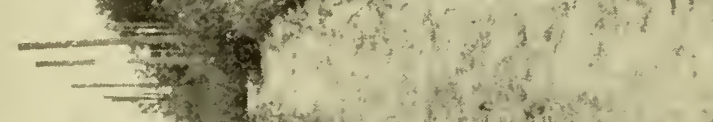

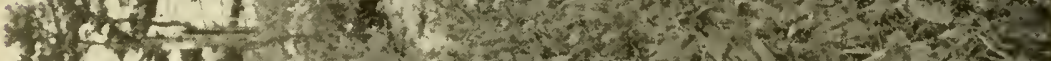

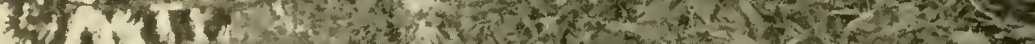

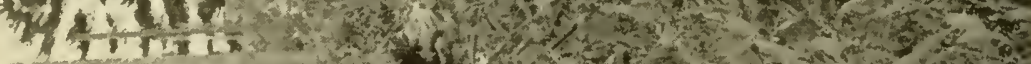

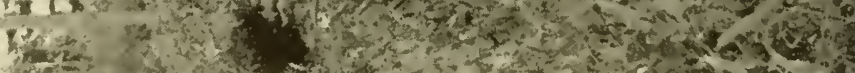
the 1 ty "3.

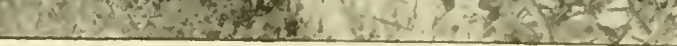




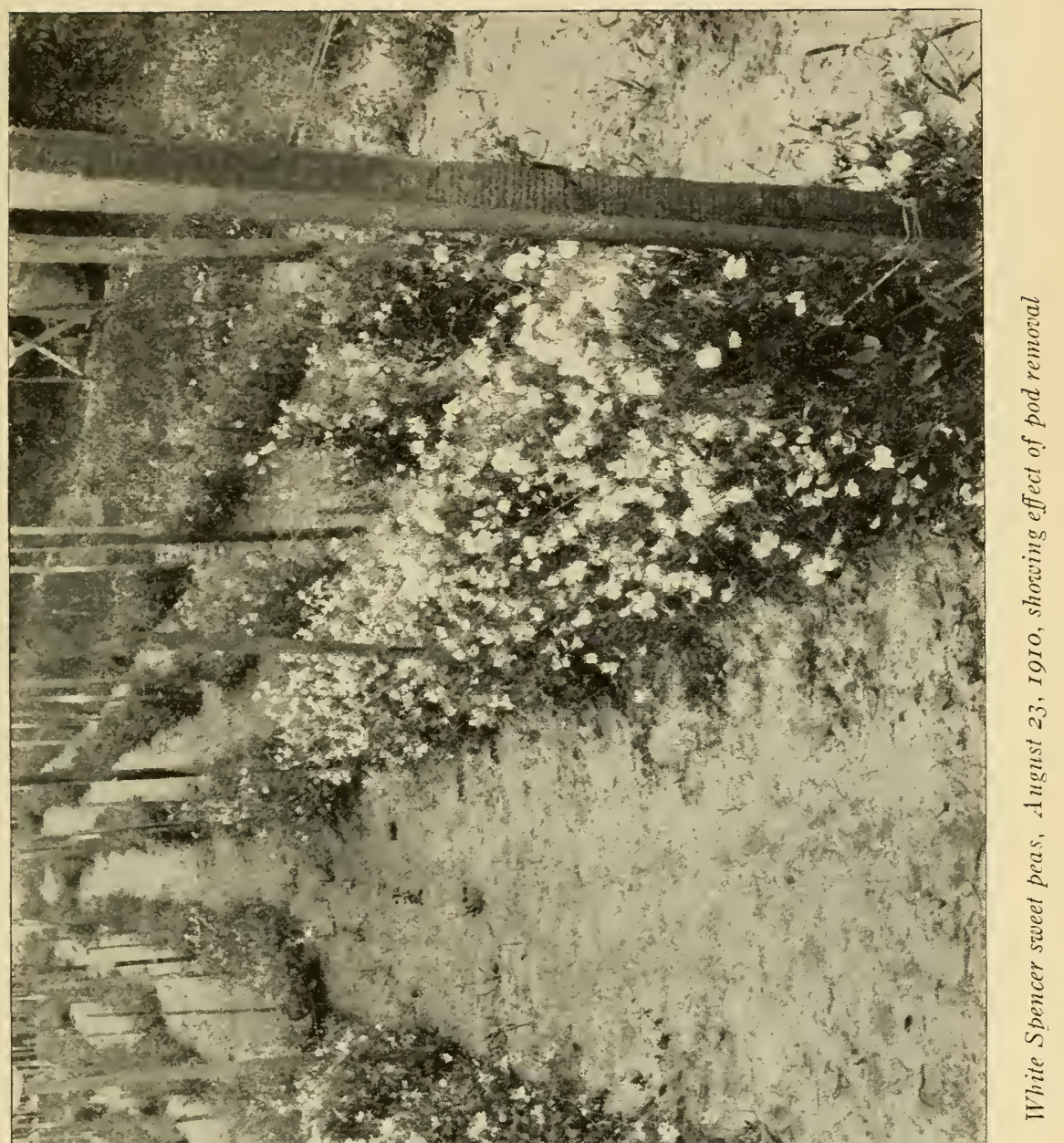

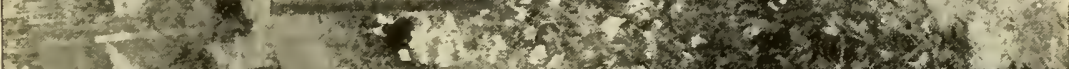

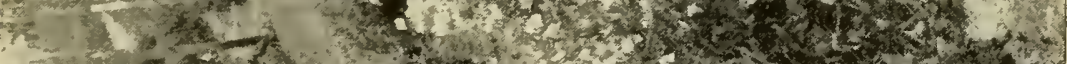
1 - 1 m.

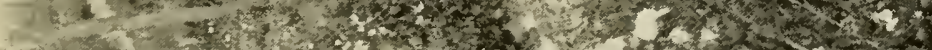

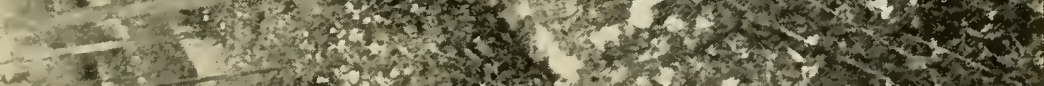

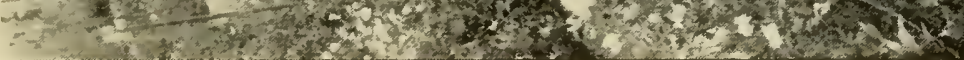



The cutworm.- In some seasons the cutworm is very destructive. The preparation of the soil in autumn, with the winter freezing, tends to eliminate this pest. The use of trap plants, such as lettuce, sown alongside of sweet pea rows has been suggested. Poisoned baits can sometimes be used, but not so safely, so far as other animal life is concerned, as in the greenhouse. The larva should be hunted down in its hiding place and destroyed. An application of soot, air-slaked lime, or tobacco dust has some value as a repellent.

\section{Diseases}

Pou'dery mildew.- Among the fungous diseases that attack sweet peas, the powdery mildew (Erysiphe Polygoni DC.) is often found late in the season, when the plants are almost through blooming. Sometimes the disease appears earlier. In I9 10 it appeared in August and proved very serious on some varieties. The stems, leaves, and other parts of the plant become covered with a white, powdery coating of the mycelium and summer spores. The disease may appear after a rain followed by very cool nights and hot days. Spraying with potassium sulfid, or dusting the plants with sulfur or with a mixture of lime and sulfur - two parts of the former to one of the latter - will control the disease.

Pea spot (Ascoplyyta pisi) is a parasitic fungus attacking sweet peas in England, and, while the writer does not know of its occurrence on sweet peas in this country, the fact that it is known to attack garden peas here is sufficient indication of danger. The disease causes round or angular spots on the leaves and pods. The spots are one fourth inch or less in diameter, usually with a narrow, but distinct, purple border. The use of potassium sulfid or dilute bordeaux mixture is recommended.

Other diseases attacking sweet peas in England are pea blight (Peronospora trifolionum), root rot (Thielavia basicola), and streak (apparently a physiological trouble).

\section{EXHIBITING SWEET PEAS}

The foundation for success in raising sweet peas for exhibition is laid the previous autumn in the thorough preparation of the soil, followed by a careful selection of varieties, thin planting, and very liberal culture. In order that good flowers may be obtained for exhibition, it is best to remove all flowers about a week before the exhibition date, and to allow only the spikes with the longest stems to develop. The size of the flowers may be increased at this time by the use of ammonia or nitrate of soda.

All varieties subject to scorch or scald should be shaded with cheesecloth or tiffany. If such varieties are planted together the shading may be more easily accomplished. The varieties having orange in their color- 
ation - that is, Henry Eckford, St. George, and Helen Lewis - the salmon varieties, and possibly some of the scarlets and blues, should be shaded for four to six days previous to the time the flowers will be needed. The shade should be so arranged that it can be removed at night.

The sweet peas having been well grown, with stems twelve to fifteen inches long, the next consideration is the cutting of the flowers; for it is one thing to grow good flowers, and quite another, but equally difficult, to exhibit successfully.

Sweet pea flowers, especially for exhibition, should be cut while dry, preferably in the morning or evening. The proper stage of development will depend on the number of hours that must elapse before the judge can pass upon the exhibit. Flowers cut the day before exhibiting should be taken with the lower flowers open and the top one in bud. Those with four flowers on a spike may be taken with the two lower flowers open, the third flower opening, and the topmost one in the bud. The flowers should be placed immediately in cool, hard water and left in a cool, dark room or cellar until they are packed. Here they are left until the latest moment consistent with their timely arrival at the exhibition hall, not more than six or seven hours if possible.

When packing, the stems should be squeezed in order to remove surplus water and then wrapped in a strip of oiled paper. Great care should be exercised not to get water on the flowers. Each bunch should be wrapped in tissue paper and the bunches packed firmly, but not so tightly as to crush the flowers.

Everything possible should be done to insure the prompt arrival of the flowers at the exhibition hall, when they should be unpacked without delay. The flowers should be loosely arranged so that they may resume their natural form after the journey.

The flowers having been put in water, the work of arranging the exhibition vases should begin. George $W$. Kerr, an experienced exhibitor, gives the following on the arrangement of the flowers:

"In staging the flowers never crowd them. Let every flower 'speak for itself.' 'Twenty sprays make a nice vase, and the best method of arranging them is to start by putting some grass (cut two inches long) in the mouth of the vase, as this helps to keep the stems in position. Each stem must be put in separately. Let every flower be seen as far as possible and all face one way, with the exception of such varieties as have the back of the standards tinted in coloring other than the ground color of the flower, when the position of such might be judiciously varied. One or two pieces of foliage - a little Gysophila - or light grass, such as Agrostis ncublosa, might with advantage be used. But this should not be overdone, and only if the rules allow of it. 
"In staging a collection of twelve varieties, they should be stood in three rows, the back rows being tiered eight or nine inches above the other, and arrange the colors so that they do not clash. Even if the show schedule does not ask for it, name each variety with a neat card placed at the base of each vase."

Two very important points for the exhibitor to observe are: (I) follow the rules as to the number of stems per vase and foliage allowed; (2) see to it that the flowers are true to name. Varieties of distinct colors should be used and those that are very nearly like others in the cxhibit excluded. Finally, in placing the vases, it is important not to lose sight of the fact that a good color scheme is a great aid to success. 




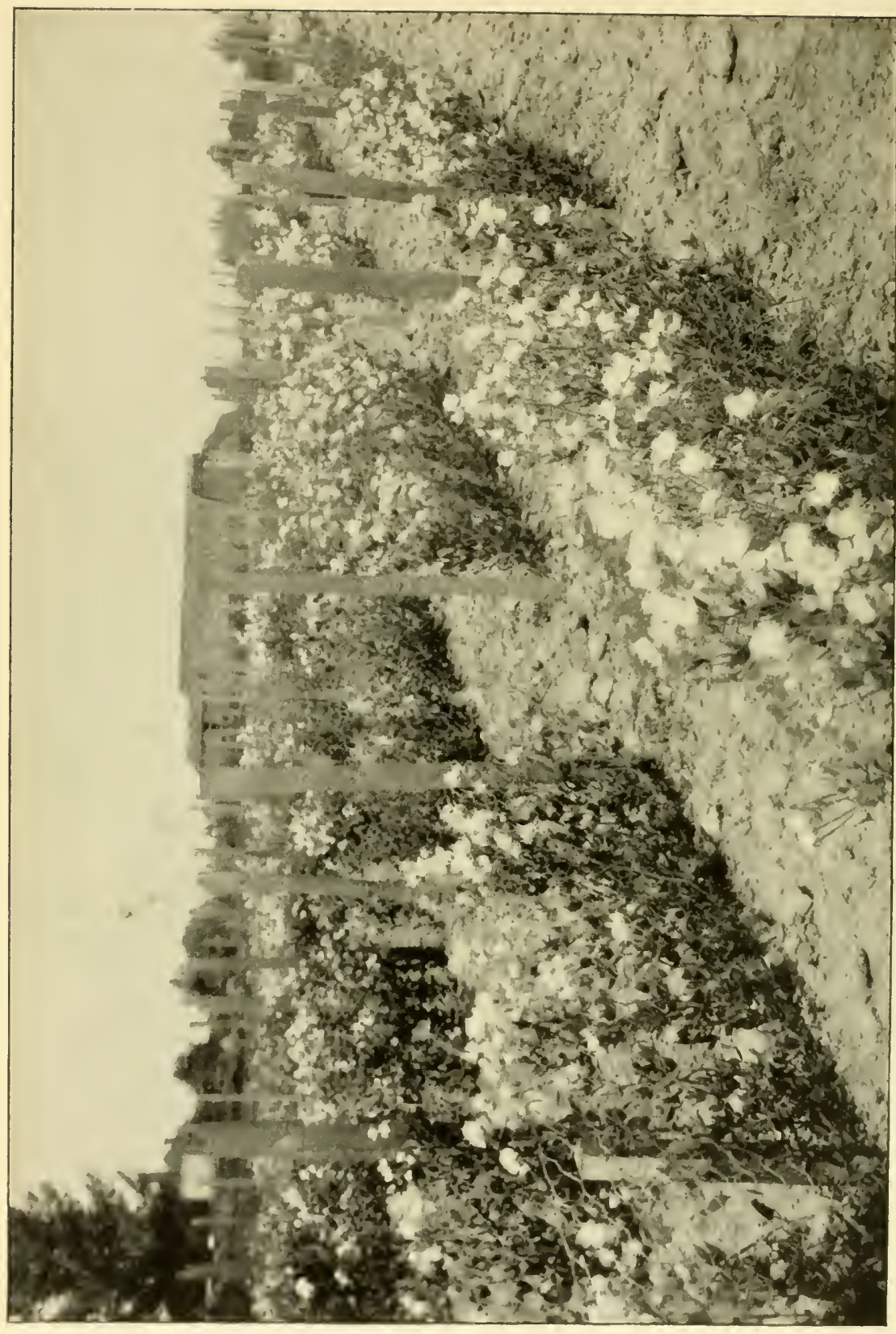




\section{CONTENTS}

Sweet-pea tests at Ithaca.

Outdoor tests ....................................... 2 I9

Successive fall plantings. . . . . . . . . . . . . . . . . . 2 I9

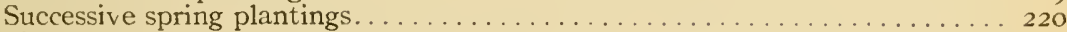

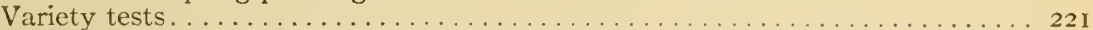

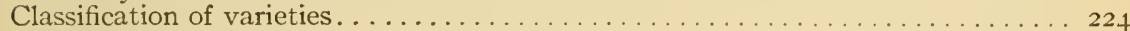

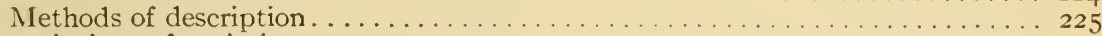

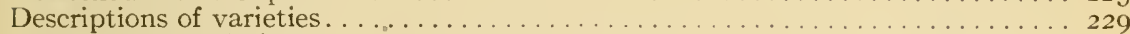

Open-form varieties .................................. 229

Bicolor (Blanche Ferry group) . . . . . . . . . . . . . . . . . 229

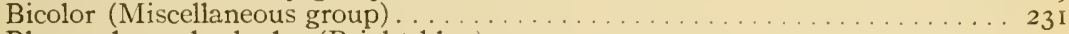

Blue and purple shades (Bright blue) . . . . . . . . . . . . . . . 232

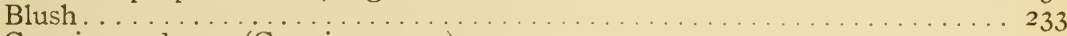

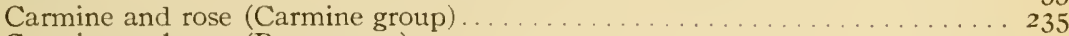

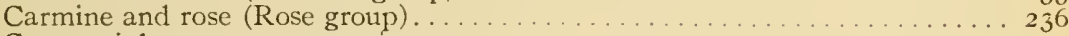

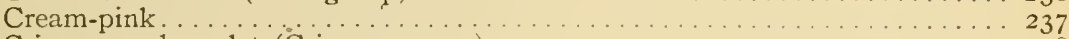

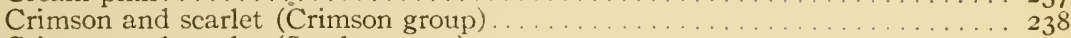

Crimson and scarlet (Scarlet group) . . . . . . . . . . . . . . . . 239

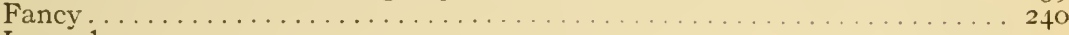

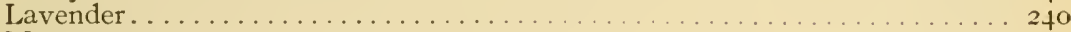

Magenta-rose........................... $2+1$

Marbled ........................... $2+1$

Maroon shades (Claret group) ..................... $2+1$

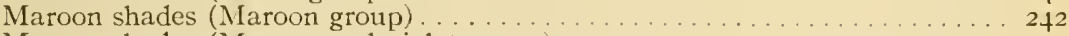

Maroon shades (MIaroon and violet group) $\ldots \ldots \ldots \ldots \ldots \ldots \ldots \ldots \ldots \ldots \ldots \ldots \ldots \ldots$

Mauve. ................................... $24+4$

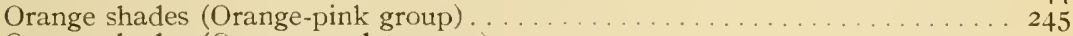

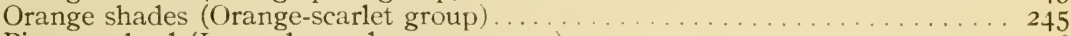

Picotee edged (Lavender and mauve group) . . . . . . . . . . . . . . . . 246

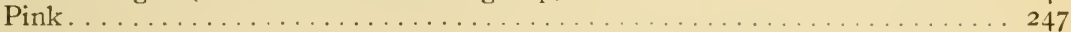

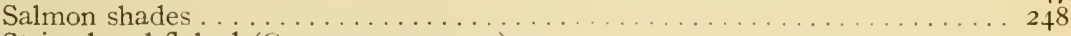

Striped and flaked (Orange-rose group) . . . . . . . . . . . . . 249

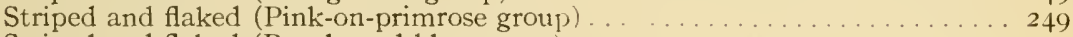

Striped and flaked (Purple and blue group) ..................... 249

Striped red and rose (Crimson-on-white group) $\ldots \ldots \ldots \ldots \ldots \ldots \ldots \ldots \ldots \ldots \ldots \ldots \ldots$

Striped red and rose (Pink-on-white group) .................. 25 I

White..................................... 252

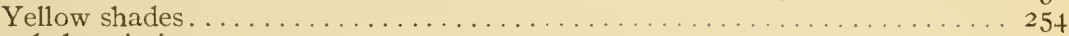

Hooded varieties. . . . . . . . . . . . . . . . . . . . . . . 255

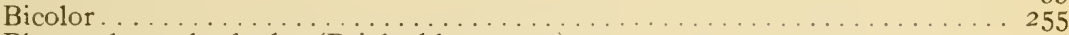

Blue and purple shades (Bright blue group) . . . . . . . . . . . 256

Blue and purple shades (Purple standard, blue wings) . . . . . . . . . 257

Blue and purple shades (Violet and indigo group) . . . . . . . . . . 258

Blush.................................... . 259

Carmine and rose (Carmine group) . . . . . . . . . . . . . . 260

Carmine and rose (Rose group) . . . . . . . . . . . . . . . . . . .

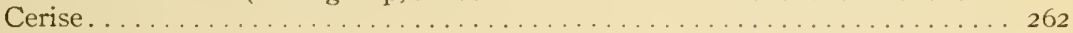

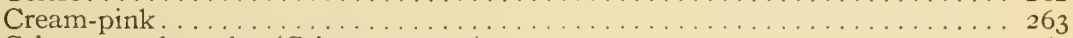

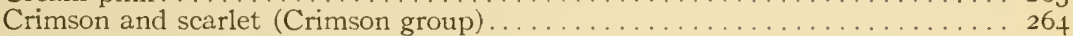

Crimson and scarlet (Scarlet group) . . . . . . . . . . . . . . . 266

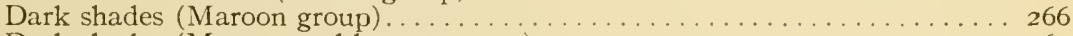

Dark shades (Maroon and bronze group) . . . . . . . . . . . . . . 267

Dark shades (Maroon and violet group) . . . . . . . . . . . . . . . 268

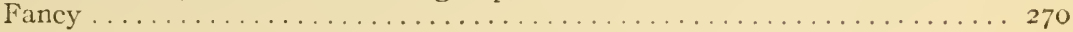




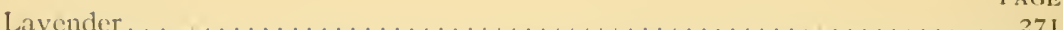

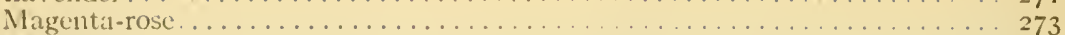

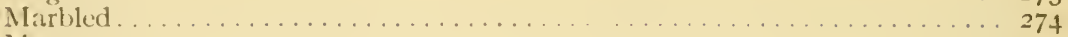

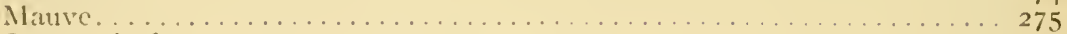

Oránge shades. . . . . . . . . . . . . . . . . . . . . . . . . . . 276

Picotee edged (Lavender and blue group) . . . . . . . . . . . . . . . . . 277

Picotee edged (Pink group) . . . . . . . . . . . . . . . . . . . . 279

Pink ... . . . . . . . . . . . . . . . . . . . . . . . . . . . 280

Striped and flaked (Chocolate stripes) . . . . . . . . . . . . . . . 28I

Striped and flaked (Mauve or bluc) . . . . . . . . . . . . . . . . . 28 I

Striped and flaked (Red and rose on primrose ground) . . . . . . . . . . 282

Striped and flaked (Red and rose on white ground) . . . . . . . . . . . . 283

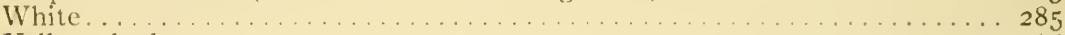

Yellow shades. . . . . . . . . . . . . . . . . . . . . . . . . . . . . 286

Extreme hooded varieties. . . . . . . . . . . . . . . . . . . . . . . . . 288

Snapdragon . . . . . . . . . . . . . . . . . . . . . . . . . . 288

Waved varieties. . . . . . . . . . . . . . . . . . . . . . . . . 290

Bicolor. . . . . . . . . . . . . . . . . . . . . . . . . 290

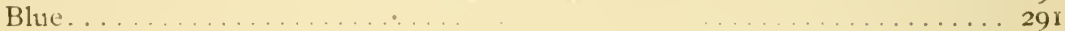

Blush. . . . . . . . . . . . . . . . . . . . . . . 293

Carmine. . . . . . . . . . . . . . . . . . . . . . . . . 295

Cerise. . . . . . . . . . . . . . . . . . . . . . 296

Cream, buff, and ivory . . . . . . . . . . . . . . . . . . 297

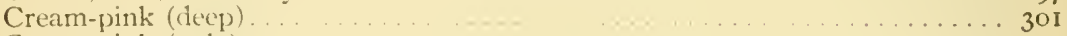

Cream-pink (pale) ... . . . . . . . . . . . . . . . . 303

Crimson........................................ 306

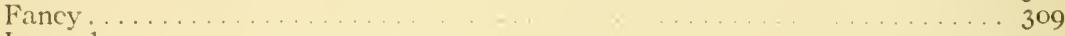

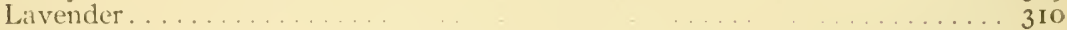

Magenta........................... 3 I6

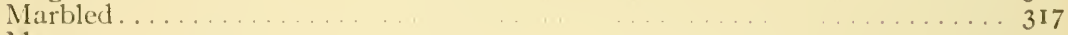

Maroon................................. 3 I 7

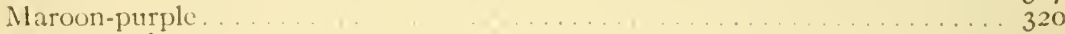

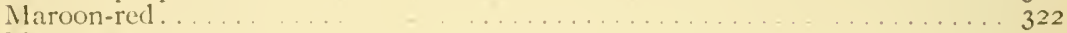

Mauve. . . . . . . . . . . . . . . . . . . . . . . . . 322

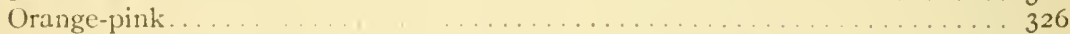

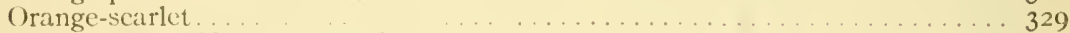

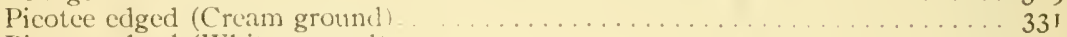

Picotee edged (Wlite ground) . . . . . . . . . . . . . . . . . . . . 332

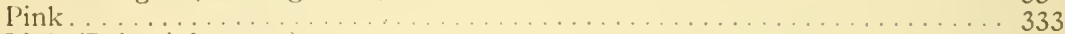

Pink (Pale pink group) . . . . . . . . . . . . . . . . . . . 336

Rose. . . . . . . . . . . . . . . . . . . . . . . . . . . . . . . . . . . 337

Salmon sliades. . . . . . . . . . . . . . . . . . . . . . . . . . . . . 338

Scarlet . . . . . . . . . . . . . . . . . . . . . . . . . . . . . . 339

Stripeet and flaked (Chocolate on graty ground) . . . . . . . . . . . . . 343

Striped and flaked (Orange-scarlet stripes) . . . . . . . . . . . . . . . . . 343

Striped and flaked (Pink on primrose ground) . . . . . . . . . . . . . . . . 34t

Striped and flaked (Purple and blue) . . . . . . . . . . . . . . . . . . 345

Striped and flaked (Red on white ground) .......................... 347

Striped and flaked (Rose on primrose ground) . . . . . . . . . . . . . . . 349

White . . . . . . . . . . . . . . . . . . . . . . . . . . . 349

The best varieties of sweet peas . . . . . . . . . . . . . . . . . . . . . .

IVaved varieties. . . . . . . . . . . . . . . . . . . . . . 352

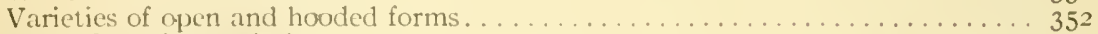

Early-flowering varicties . . . . . . . . . . . . . . . . . . . . . 353

Market varieties. . . . . . . . . . . . . . . . . . . . . . . . . 353

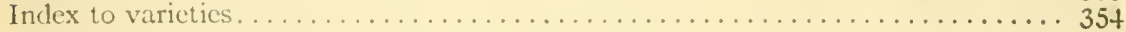




\title{
SWEET-PEA STUDIES-IV
}

\section{CLASSIFICATION OF GARDEN VARIETIES OF THE SWEET PEA}

\author{
Alvin C. Beal \\ (Received for publication January 3, I9I4) \\ SWEET-PEA TESTS AT ITHACA
}

The great epoch in the growing of sweet peas in America began with the introduction of the Eckford varieties in I886, and received impetus from the introduction of the American variety Blanche Ferry in I889. About this time it was discovered that, owing to climatic conditions, California was adapted to the production of large quantities of sweet-pea seed. This made it possible to meet the heavy demand that arose during the last decade of the nineteenth century, when sweet peas were unprecedentedly popular. At that period sweet-pea exhibitions were held, and flowers were grown in almost every garden. No other annual flower, to the writer's knowledge, has ever approached the sweet pea in the magnitude of its growth in popular interest.

Then came a wane for a few years, apparently due to the cultural methods employed and to the appearance of diseases. But the flower is again coming into its own. In the meantime the waved type has been developed. In the closing days of Mr. Eckford's busy life he saw the awakening interest in sweet peas on the part of the English people. The introduction of the variety Countess Spencer in I 904 raised this interest to fever heat, and a national sweet-pea society - which is now one of the largest horticultural associations in the world, numbering over one thousand subscribers - was organized in England.

Many growers have undertaken the work of further improving this flower, and, due to this and to the sportive tendencies of the waved type of sweet peas, the number of varieties has increased at a rate hitherto undreamed of. In the contest for novelties many growers have found the same sports, have named them, and have sent them out, so that we have more than one name for the same variety. It appears also that some growers have been in too great a hurry to send out novelties before assuring themselves that their varieties were fixed. Sometimes a secdsman thought he had a fixed stock, only to find, after having introduced it, that it varied wherever grown. The novelties for Io I I include not less than eighty-five varietics. For several years past the offerings have exceeded fifty varieties a year, so that now there are almost a thousand variety names of sweet peas. 
With the view of furthering interest in the sweet pea as a flower for the masses, the American Sweet Pea Society, at its inception in July, 1909, decided to establish trial grounds for the elimination of synonyms and the testing of new varieties. The trial grounds were established at Cornell University, through a cooperative arrangement between the Department of Horticulture of the New York State College of Agriculture and the society. The latter was to supply the seed, and the former was to conduct the tests in conjunction with a committee on nomenclature appointed by the society. In order to enlist the largest number of growers in the work of the trial grounds each year, a circular letter was sent to every firm offering new varieties of sweet peas. The growers named below have sent varieties for trial:

Great Britain: Aldersey \& Marsden Jones, Tilston, Malpas, Cheshire; IV. E. Alsen, Denmead, Waterlooville, Hants; R. H. Bath, Wisbech; S. Bide \& Son, Farnham, Surrey; James Box, Haywards Heath, Sussex; William Deal and E. J. Deal, Kelvedon; Silas Cole, Northampton; T. H. Dipnall, Hadleigh, Suffolk; Dobbie \& Co., Edinburgh, Scotland; Miss Hilda Hemus, Upton-on-Severn; Kelway \& Son, Langport, Somersetshire: E. IV. King \& Co., Coggeshall, Essex; Alexander Malcolm, Duns, Scotland; S. Miller, Newport, Isle of Wight; G. Stark \& Son. Great Ryburgh, Norfolk; Sutton \& Sons, Reading; Robert Sydenham, Birmingham; IV. J. Unwin, Histon, Cambridgeshire; Watkins \& Simpson, London.

United States: A. T. Boddington, $3+2$ West Fourteenth Street, New York; IV. Atlee Burpee \& Co., North Fifth Street, Philadelphia; Peter Henderson \& Co., 35 Cortlandt Street, New York; C. C. Morse \& Co., 48-56 Jackson Street, San Francisco; W. W. Rawson \& Co. (now Fottler, Fiske, Rawson Company), Boston; Waldo Rohnert, Gilroy, California; Vaughan's Sced Store, 31-33 West Randolph Street, Chicago; James Vick's Sons, Rochester, New York; Ant. C. Zvolanck, Bound Brook, New Jersey.

From this list it will be seen that most of the really progressive growers who are intensely interested in the permanent development of sweet-pea culture have assisted in the work. To these and to all who have assisted in the work the American Sweet Pea Society and the New York State College of Agriculture are indebted. It is hoped that the cordial support. hitherto given to the work may be continued for the further advancement of the sweet pea in popular favor.

On reccipt of the secds a list of all the varietics, with the date of their reccipt, was made. A card index was also prepared, so that any arrangement of the varicties could be made. On these cards the trial number was entered so that the variety could be quickly found in the ficld. 


\section{OUTDOOR TESTS}

In addition to the purposes of the trials before mentioned, it was thought desirable to make some cultural tests as to the effect of the time, depth, and thickness of planting on the resultant crop. With this in view, plantings were made in the fall and in the spring.

\section{Successive fall plantings}

Many of the dealers sent in seeds promptly, and in order to test the feasibility of growing sweet peas successfully from fall planting the trials were begun very soon after the writer entered upon the work. Plantings made at this station at intervals of ten days, from October 20 to November 30 , I909, gave the following results:

TABle i. Resllts from Fall Plantings

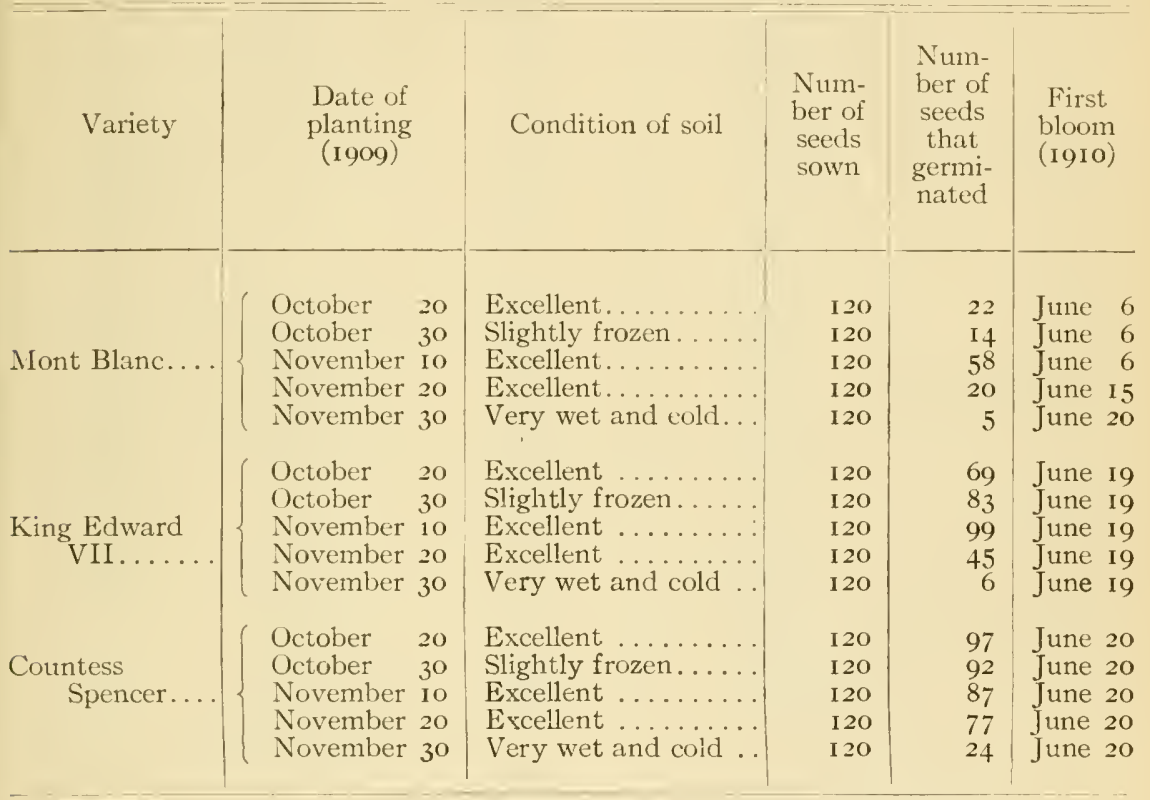

In all these trials there was no top growth, but some plants of the first two plantings were just piercing the surface, when winter set in. The third planting germinated, but the last two did not appear above the surface of the ground until the following April (I9I0), when they appeared on the $4_{\text {th }}$ and the 15 th, respectively.

The results indicate that the planting should be delayed as late as is practicable, but not so late that the seed must be sown in a cold, wet, heavy soil. 


\section{Successive spring plantings}

The spring plantings were not made at uniformly regular intervals, as were the fall plantings, because of the cold, wet weather of April, igio, and the heavy rains of May. However, the results are comparable, for the same varieties, from the same consignment of seed, used in the fall plantings were used in these tests.

TABLE 2. Results from Spring Plantings

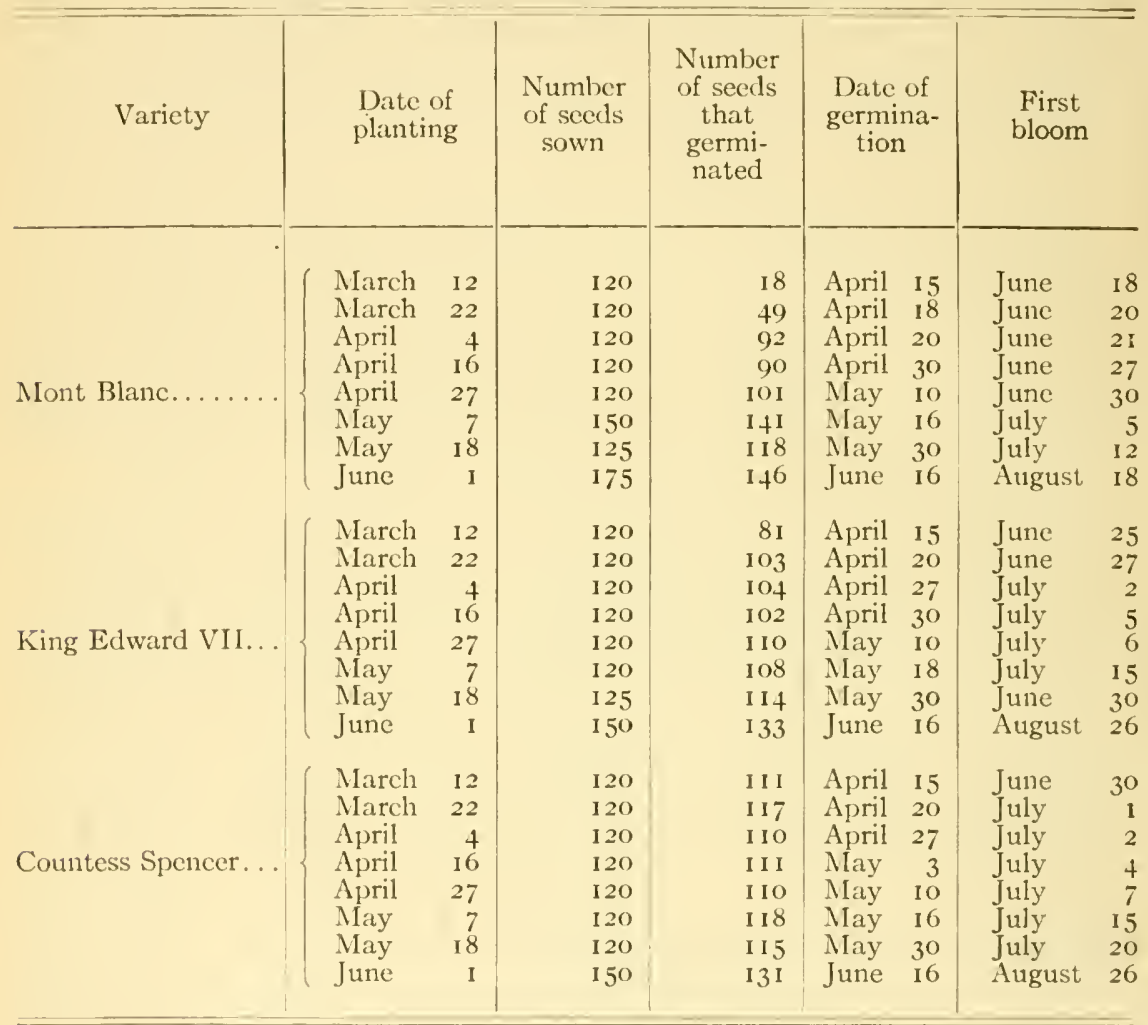

It is very apparent, in view of the results from the germination of the varicty Mont Blanc, that white-seeded sweet peas should not be sown until the ground has thoroughly thawed.

The most significant fact in connection with these trials was the manner in which the dry, hot weather hurried forward the April plantings so that they came into bloom together.

The height of the plants varied directly with the time of planting, the first being the tallest. The amount of bloom on all spring plantings 
after the first three was much reduced and the length of the stems was considerably less. However, the late April and early May plantings produced a number of blooms, and with more rain and with fertilizers the results would doubtless have been fairly satisfactory.

Due to the dry, hot weather, the June planting did not flower until August, after a very feeble existence. When the mildew appeared in the latter part of August these plants were quickly destroyed, as the disease caught them at the time when they were beginning more rapid growth.

The results of igro indicate that plantings of garden varieties made after May to are really not worth while.

\section{VARIETY TESTS}

Each year a different area has been selected for growing the plants. Soil as nearly uniform as possible has been chosen. The land is plowed in the autumn, and furrows are opened with the plow so that barnyard manure can be placed under the rows preparatory to spring planting. When the furrows are closed, if a slight ridge is left over the row it can be raked down as soon as the surface dries in the spring, thus facilitating early planting. The varieties under test in I9I0, 19II, and I9I 2 were sown in the open ground as early as possible. In I9I3 all the varieties were sown in pots in March and were planted later in the field. The results from the latter method were so much better that that method will be continued.

In the first year the rows were 20 feet long and 4 feet apart. Four hundred and five of these rows were planted, giving a total length of row of 8 ioo feet, or a little over one and one half mile. The total length of row grown in I9II was 4500 feet, in I9I 2 it was 3000 feet, and in I9I3 it was about 2000 feet. In the first two years a large number of the older varieties were grown, but in the last two years only the leading varieties of the older types were grown. The work has now reached the stage when only one variety of the older type in each color section will be grown for comparison.

A record was made of the number of seeds planted of each variety, and later the number that germinated was recorded. Of the standard varieties $\mathrm{I} 20$ seeds were usually planted in each row; with samples that appeared to be of poor quality, however, a good stand was assured by sowing more seeds. The question is sometimes asked whether old sweetpea seed will grow. An opportunity to test this was afforded by seeds sent in by Mr. Morse for study of the obsolete types. This seed was saved some years before, when variety tests were being made, and the following results shed some light on the question: 


\section{TABLE 3. Germination of Old Sweet-Pea Seed In 1910}

(The asterisk denotes white-seeded varieties)

\begin{tabular}{|c|c|c|c|c|c|}
\hline Variety & Crop of & $\begin{array}{l}\text { Number } \\
\text { planted } \\
\text { on } \\
\text { April I } 5\end{array}$ & $\begin{array}{l}\text { Number } \\
\text { germi- } \\
\text { nated }\end{array}$ & $\begin{array}{l}\text { Date } \\
\text { of } \\
\text { germi- } \\
\text { nation }\end{array}$ & \\
\hline Black Brown Stripe. & 1904 & 125 & 19 & May & \\
\hline Purple Brown Stripe. & 1902 & 125 & to & May & 8 \\
\hline Striped Colestial . . . $\ldots \ldots \ldots \ldots \ldots \ldots$ & 1902 & 12.5 & 92 & May & T \\
\hline Columbia. . . . . . . . & 1902 & 125 & 51 & May & 7 \\
\hline Juanita. & 1903 & $15^{\circ}$ & 42 & May & 7 \\
\hline Daybreak. & 1904 & 150 & 75 & May & 7 \\
\hline Gaiety ..... & I9OI & 125 & 40 & May & 7 \\
\hline Wawona. & 1903 & 125 & 77 & Nay & 7 \\
\hline Duchess of York. & 1904 & 125 & 103 & May & 6 \\
\hline Splendour. . & 1903 & 125 & 82 & Nay I & IO \\
\hline Large Yellow Red... & 1902 & 125 & 75 & May i & 10 \\
\hline 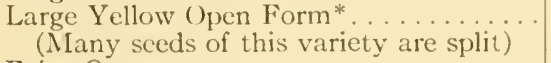 & 1901 & 175 & 3 & May I & 10 \\
\hline 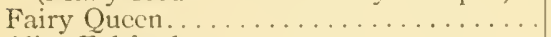 & I90I & 125 & $6 I$ & Nay 1 & 10 \\
\hline Alice Eckford. & 1904 & 175 & 104 & May & \\
\hline Lady Beaconsfield. & 1903 & 125 & 78 & Nay & \\
\hline Countess of Shrewsbury............ & 1902 & 125 & 47 & May I & 12 \\
\hline Delight $\ldots \ldots \ldots \ldots \ldots \ldots \ldots$ & 1903 & 125 & 98 & May & 8 \\
\hline Lemon Queen & 1903 & I 33 & 53 & May I & 10 \\
\hline Peach Blossom. & 1904 & โ25 & 105 & May & 4 \\
\hline Crown Princess of Prussia............. & 1903 & 175 & 31 & May $\mathbf{~}$ & 10 \\
\hline 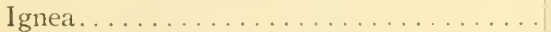 & 1903 & 125 & 85 & May & + \\
\hline Carmine Invincible. & 1904 & $15^{\circ}$ & 127 & May & 4 \\
\hline Brilliant . . . . $\ldots$ & 1904 & 125 & 112 & May & + \\
\hline Cardinal. & 190.4 & 125 & 107 & May & + \\
\hline Bronze King & 1901 & 125 & 14 & May & 6 \\
\hline Empress of India.. & I904 & 152 & 90 & May & 6 \\
\hline Emily Lynch. & 1904 & 125 & I 15 & May & + \\
\hline Coronet. & 1902 & 125 & I 5 & May & + \\
\hline Orange Prince & 1903 & 125 & 46 & May 1 & 12 \\
\hline Meteor. & 1902 & 150 & 52 & May I & IO \\
\hline Alba Magnifica*. & 1903 & 175 & 50 & May & + \\
\hline Queen of England* & 1903 & 150 & 62 & May & 4 \\
\hline Dorothy Vick..... & 1903 & 125 & 99 & May $\mathbf{~}$ & 10 \\
\hline Princess Victoria... & I903 & 125 & 87 & May & 6 \\
\hline Rising Sun . & 1902 & 125 & 46 & May 1 & If \\
\hline Duchess of Edinburgh & 1903 & 125 & 57 & May I & I0 \\
\hline Queen of the Isles... & 1904 & 125 & 99 & May & + \\
\hline Adonis . . . . . . . . . & 1904 & 150 & 126 & May & + \\
\hline Miss llunt. & 1904 & 125 & 102 & May & + \\
\hline Novelty. & 1903 & 125 & 62 & May & 8 \\
\hline Fluted Primrose*. & 1901 & 150 & I & May I & It \\
\hline Ovid. & 1904 & 125 & 114 & May & \\
\hline King Edward VII & I909 & 90 & 85 & May & + \\
\hline Countess Spencer. & 1909 & 90 & 83 & May & 5 \\
\hline Oddity.... & 1904 & 125 & 115 & May & 4 \\
\hline Inconstancy ${ }^{*}$ & 1902 & 175 & 6 & May I & 12 \\
\hline Golden Gleam* & 1904 & 150 & IOI & May & 4 \\
\hline Mont Blane*. & 1909 & 175 & $1+6$ & May & 4 \\
\hline
\end{tabular}


It is apparent that the white-seeded varieties lose their vitality in greater degree than do the black-seeded varicties of the same year's crop. Nearly all varieties from the 1904 crop gave as good results as were obtained, in general, from the i 909 crop.

Only a small number of seeds were received of the new varieties and of the novelties. The smallest number of seeds of any variety was five, but in several cases only eight or ten were received. When a few seeds of a variety were to be sown it was arranged to sow one or two other varieties in the same row, leaving a space of eighteen inches between two separate varieties. In the past season, I9I3, the length of row was reduced to ten feet because of the greater ease of supporting the plants and because in many cases only five to ten seeds were received. If an equal number of plants were obtained, one half or all of a ten-foot row could be planted to a variety. A crosswalk six feet wide separated each section. This allowed for spraying the plants when necessary.

The varieties were arranged according to color, for the purpose of easy comparison in the determination of synonyms and in the estimation of the value of varieties, relative productiveness, and other points. The arrangement insured the varieties' being sown or planted at the same time, on as nearly as possible the same soil, and with the same exposure.

The question of a suitable support was given considerable thought. After an investigation of the various forms of wire netting suitable for the purpose, it was fornd that its expense was too great to allow of its use with this area of sweet peas. The method adopted was to place a seven-foot stake at the end of each row and use heavy twine for supporting the plants. The twine was stretched along one side of the row and back on the other, enclosing the plants. While this method was reasonably economical it was not very satisfactory, for the reason that the expansion and contraction of the twine prevented it from supporting the plants properly. The slackened strings allowed the wind to topple the plants alternately back and forth It was found that this could be overcome by placing the supports closer together. In I9I3 the use of the string support alone was abandoned, and a strip of wire netting twentyfour inches wide was used near the ground. It was found that this provided a better support for the young plants, for if they were torn loose by the wind they could be tied up with raffia. As soon as the plants were well started, little difficulty was experienced in keeping them straight. The use of strings for supporting the tops of the plants has been found satisfactory, provided the plants do not reach a total height of more than four feet. If under garden conditions the plants grow taller than four feet, the width of the strip of netting should be correspondingly increased. 


\section{CLASSIFICATION OF VARIETIES}

The rapidly increasing number of varietics of sweet peas offered since Mr. Eckford began the improvement of the flower has made it imperative that some method of elassifying varieties should be adopted. In the autumn of 1896 the Sunset Seed and Plant Company issued a small work entitled "Sweet Pea Review," in which was proposed a classification of sweet peas based on form. Average specimens of the largest and most perfect standards of Eckford's introductions of I 896 and i 897 were selected, and, each being laid down naturally, with the front side uppermost, a circle was drawn around it just touching the extreme edges. Within each circle an outline drawing representing a certain type was made.
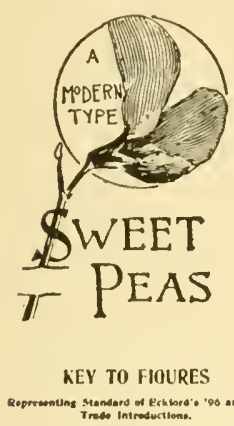

Fig. I-Alke Eckford

Fik. 2 -Counless of Shrewabury

Fig. 3-Unile Dorril

Fig. 4 Captivation

Fig. S Countews of Aberdern

Fig. - Prime Donne

Fig. 7-Lovely

FIg. 8-rikedo

Fig. Q...Mers

Fix. 10 Royal Rono

Fig. 11 Coynetle

Fig. 12 - Crow dew

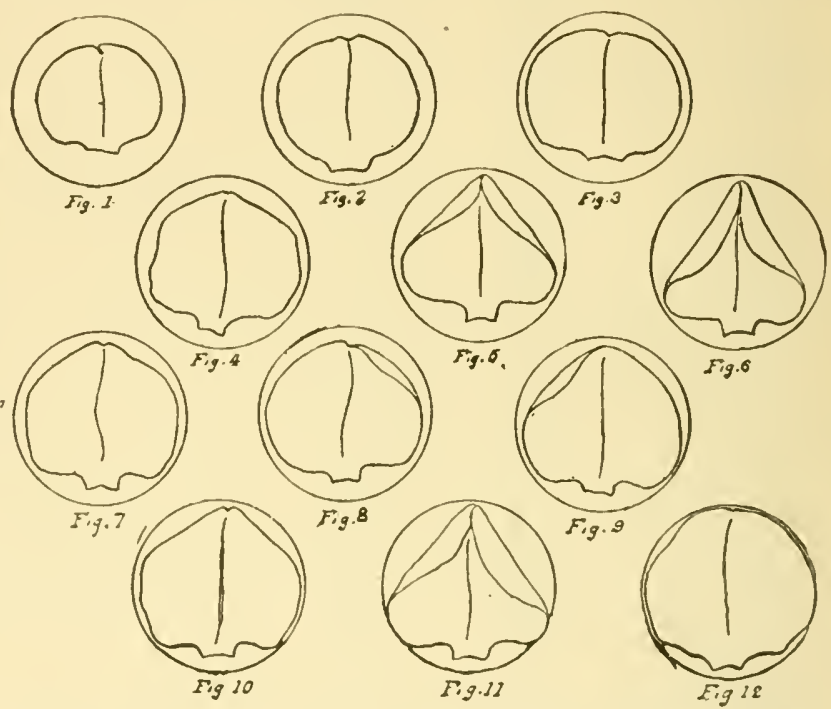

FIG. 24.- Classification of sweet peas, suggested by the Sunset Seed and Plant Company, San Francisco, California

The diameter of the circles was thirty-eight millimeters, or a trifle over one and one half inch, and represented the grandiflora size as this company understood it. A perfect type of flower is illustrated as one in which the farthest projections of the standard, wings, keel, and calyx exactly touch the thirty-eight-millimeter circle. The ninety varicties of sweet peas grown by the company were classified into twelve types.

This classification based on form has not been adopted by growers of sweet peas. The method was copyrighted, which possibly had something to do with the fact that it never became popular. A more important reason, no doubt, is the fact that the size, and also to some extent the form, 
of sweet-pea flowers are dependent on the culture that they receive. Under a hot sun the various flowers on a plant assume different forms according to the length of time that the blossoms have been open. At the present time the system would not be very serviceable in describing varieties of the waved form, since the amount of the waving or the folding of the standard varies with the variety, the strain, or the stock, as well as with the cultural conditions.

Although varieties were rapidly multiplying, seedsmen continued to list the names alphabetically. Mr. Burpee, who catalogued one hundred and fifty varieties in $\mathrm{I} 899$ - the most extensive collection offered up to that time by any seedsman, so far as the writer can learn - classified them in this manner.

\section{METHODS OF DESCRIPTION}

The Classification Committee appointed at the Bicentenary Celebration at London in 1900 adopted the following scheme of classification, based on color instead of on form:

Selfs: Flowers with one color only; to be classified as:

$\begin{array}{lll}\text { White Selfs } & \text { Blush Selfs } & \text { Yellow or Buff Selfs } \\ \text { Pink Selfs } & \text { Rose Selfs } & \text { Carmine Selfs } \\ \text { Purple and Maroon Selfs } & \text { Crimson Selfs } & \text { Lavender Selfs } \\ \text { Mauve Selfs } & \text { Blue Selfs } & \text { Salmon and Orange Selfs }\end{array}$

Flakes: Flowers with a decided ground color, on which are flakes and stripes of another color; the color of the flakes to determine the class:

Red and Rose Flakes

Mauve Flakes

Maroon and Purple Flakes

Blue Flakes

Bicolors: Flowers with two colors, one found in the standard and the other in the wings; the color of the standard to determine the class:

Red and Rose Bicolors

Salmon and Orange Bicolors

Fancies: Flowers of several colors, and such as are not provided for in other divisions. The ground color to determine the class:

White Ground Fancies

Yellow or Buff Ground Fancies

Picotee Edge: Flowers of one or more colors, but having an edging of a distinct color or shade around the standard and the wings. No subdivision is as yet considered necessary.

The seedsmen soon began to list their varieties under the principal colors, but as a rule no classification was made as to form.

The Sweet Pea Annual for I 906 gives the following color classes: White, Crimson and Scarlet, Cerise, Rose and Carmine, Pink, Blush, Blue, Yeliow 
Shades, Orange, Lavender, Mauve, Violet and Purple, Magenta, Picotee Edged, Red Stripes, Blue Stripes, Bicolors, Fancies. This is substantially the classification that was used until igr I, except that the Cream Pink and the Marbled class were added.

The color classes for I9 I show that Crimson and Scarlet were separated, while the Orange class has been divided into Orange Pink, Orange Scarlet, and Salmon Shades. The Picotee Edged class is subdivided into Cream Grounds and White Grounds. A Lilac class has been added. There is a total of twenty-five classes.

During this period the National Sweet Pea Society of England listed the best varieties under each color class, including the best variety of the old type, which was indicated by an asterisk.

The Sweet Pea Annual for 19 3 gives the following color classes: Bicolor; Blue; Blush; Carmine; Cerise; Cream, Buff, and Ivory; Cream-pink (Pale); Cream-pink (Deep); Crimson; Fancy; Lavender; Lilac; Magenta; Marbled and Watered; Maroon; Maroon Purple; Maroon Red; Mauve (Dark); Mauve (Pale); Orange-pink; Orange-scarlet; Picotee Edged (Cream Ground); Picotee Edred (White Ground); Pink (Deep); Pink (Pale); Rose; Salmon Shades; Scarlet; Striped and Flaked (Purple and Blue); Striped and Flaked (Chocolate on Gray Ground); Striped and Flaked (Red and Rose); White. A total of thirty-two classes.

When one considers the advance from a classification that comprised only White, Cream or Light Yellow, Light Blush, Light Pink, Deep Pink, Rose, Red and Scarlet, Shades of Orange and Salmon, Pink and White, Blue and White, Claret and Maroon, Striped and Variegated, Lavender and Light Blue, and Blue and Purple, one can appreciate the fact that the classification of sweet peas has undergone evolution. Moreover, this indicates more clearly than does anything else the marvelous development of the flower.

In the Field Notes on Sweet Peas, 1907, edited by L. L. Morse, it is stated that the most natural classification is according to color, and that most seedsmen recognize such an arrangement. Mr. Morse then calls attention to the fact that another classification, almost as important as that of color, is that of form, referring to the size and the shape of the standard. He classes the varieties as follows:

\section{Hooded form}

Large...... Aurora

Medium. . Countess of Radnor

Small...... Blushing Beauty

\section{Open form}

Large...... Triumph

Medium.... Blanche Ferry

Small ..... Crown Princess of Prussia

The Countess Spencer group, which was just coming in, was classified as "rery large." This group has since been recognized universally as 

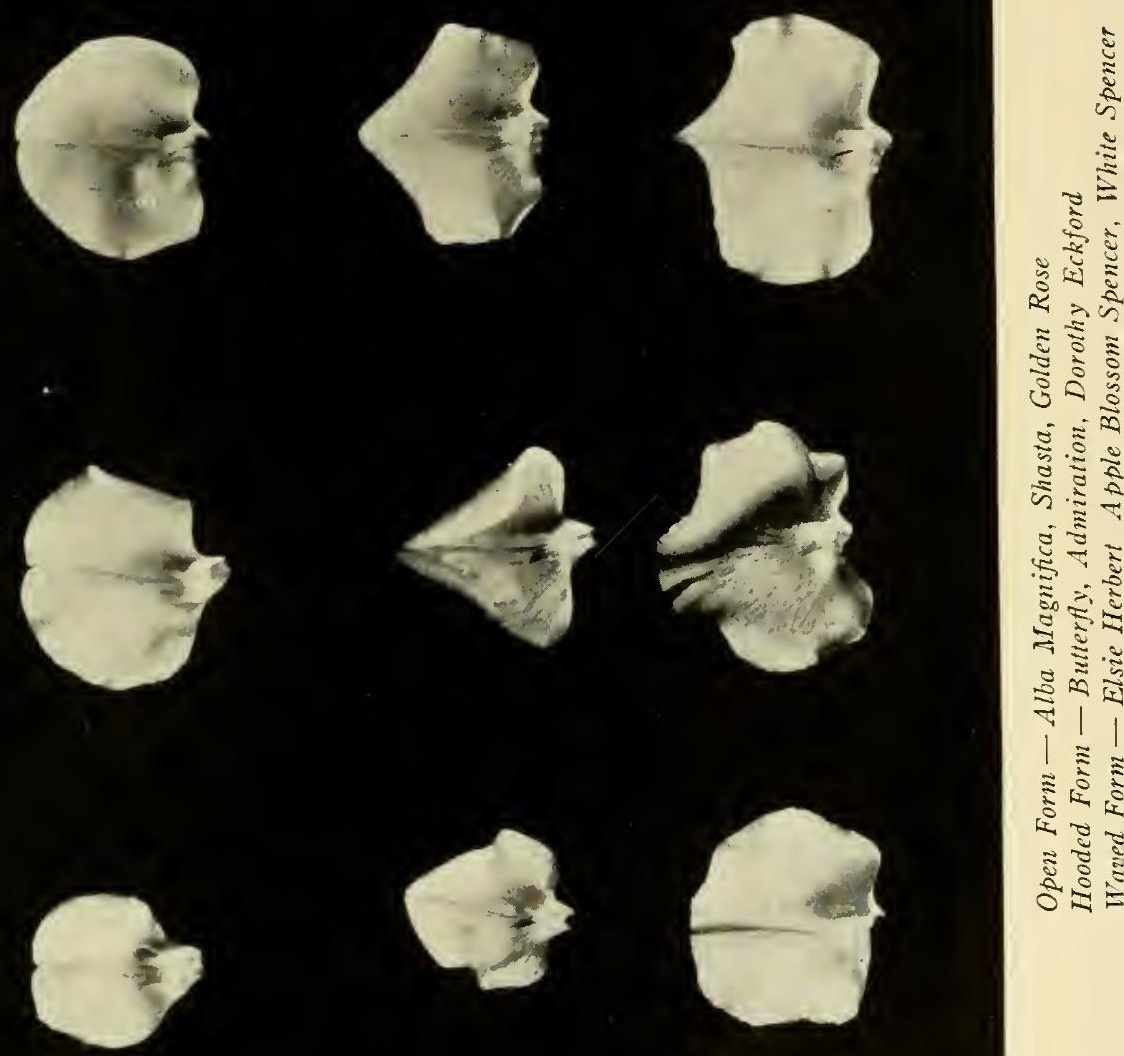


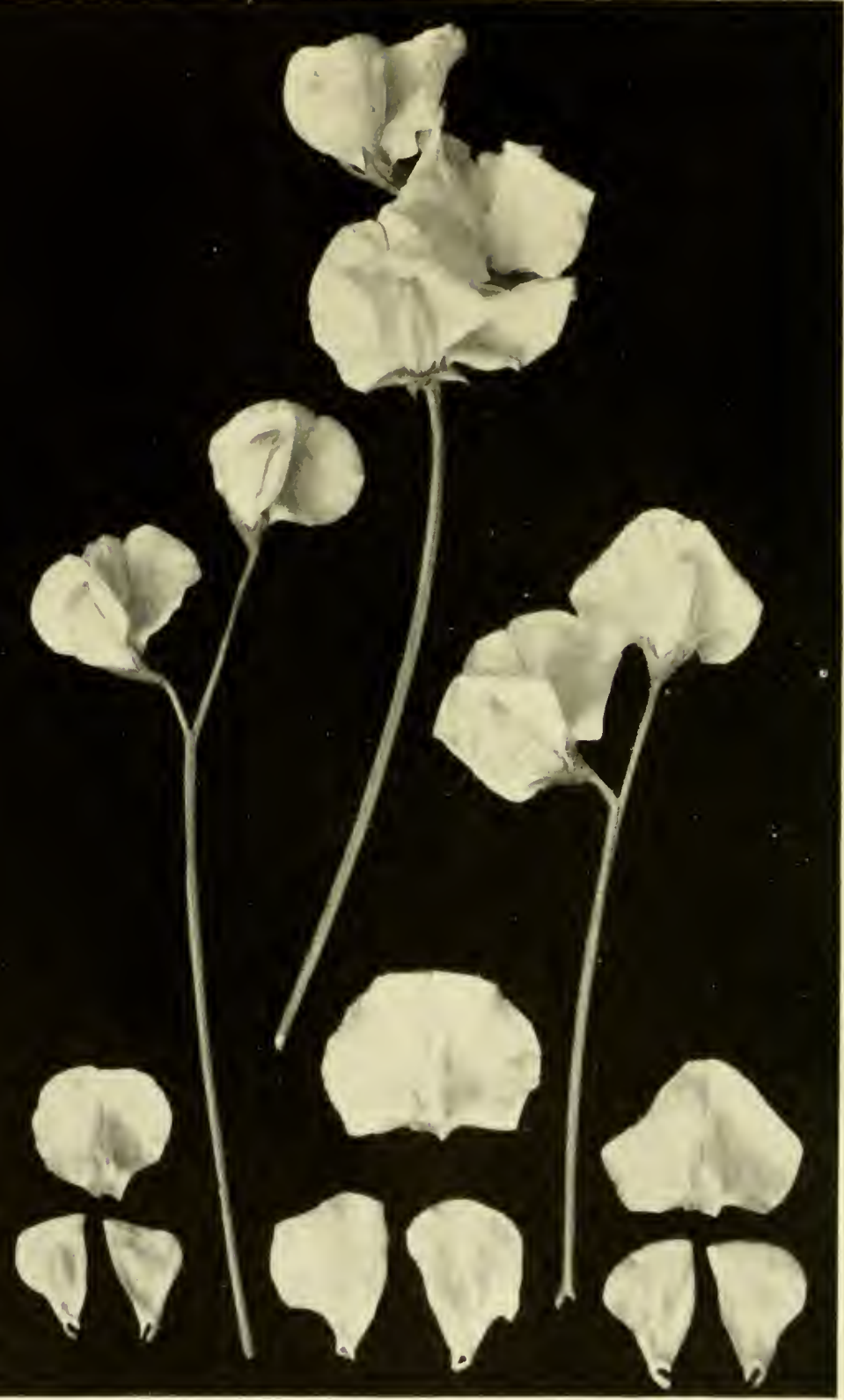

1Vrs. Sankey Spencer

Queen of England

Dorothy Eckfort 
distinct in form. The size of the varieties is of less importance at the present time, for the waved, or Spencer, sweet peas are usually of very large size, and if any of the older varieties are to persist in the trade they must be of the largest size. The varieties with medium-sized blooms are now obsolete, as were the small-flowered varieties of Morse's list.

The principal characters on which a classification of sweet peas may be based are habit of the plant, form of the flower, and color of the flower. In habit of plant, the dwarf, bush, winter-flowering, and garden types are recognized. In general there are two main groups, the dwarf forms and the tall forms, the latter including the winter-flowering and garden types. The form of the flower has been evolved from the reflexed form, through the open and the hooded, to the waved form. The open form with the flat standard may be classified into the notched and rounded types. There are various degrees of hooding, of which the extreme form is the snapdragon, now grown only as a curiosity. In like manner we find various degrees of waviness in the waved, or Spencer, form; these can be placed in groups according to the amount of waviness, being equal to, less than, or greater than, Countess Spencer under the same conditions. The writer proposes the following classification of sweet peas:

Garden type

Open form

Hooded form

Waved form
Winter-flowering type

Open form

Hooded form

Waved form

The dwarf type is not of sufficient importance to be subdivided, but it embraces varieties with flowers of both open and hooded form.

Under each form the varieties are classified by color, using the color classification of the English National Sweet Pea Society. So far as possible, the Répertoire de Couleurs was used in determining the color of all the varieties of sweet peas grown. In the description of each variety the relative size of the flower is recorded.

The descriptive blank shown on page 228 was prepared for recording the data on varieties. The plantings in the field were labeled by number only, and the corresponding number was placed under its heading on the card; so that in making the records it was not known who sent the variety under examination. The data on the upper part of the card were not entered until after the season was over. This practice was followed in order to keep the records free from the possibility of bias as to the estimate placed by others on a variety. The information given is therefore our own, except when it is specifically stated to be the opinion of another. 


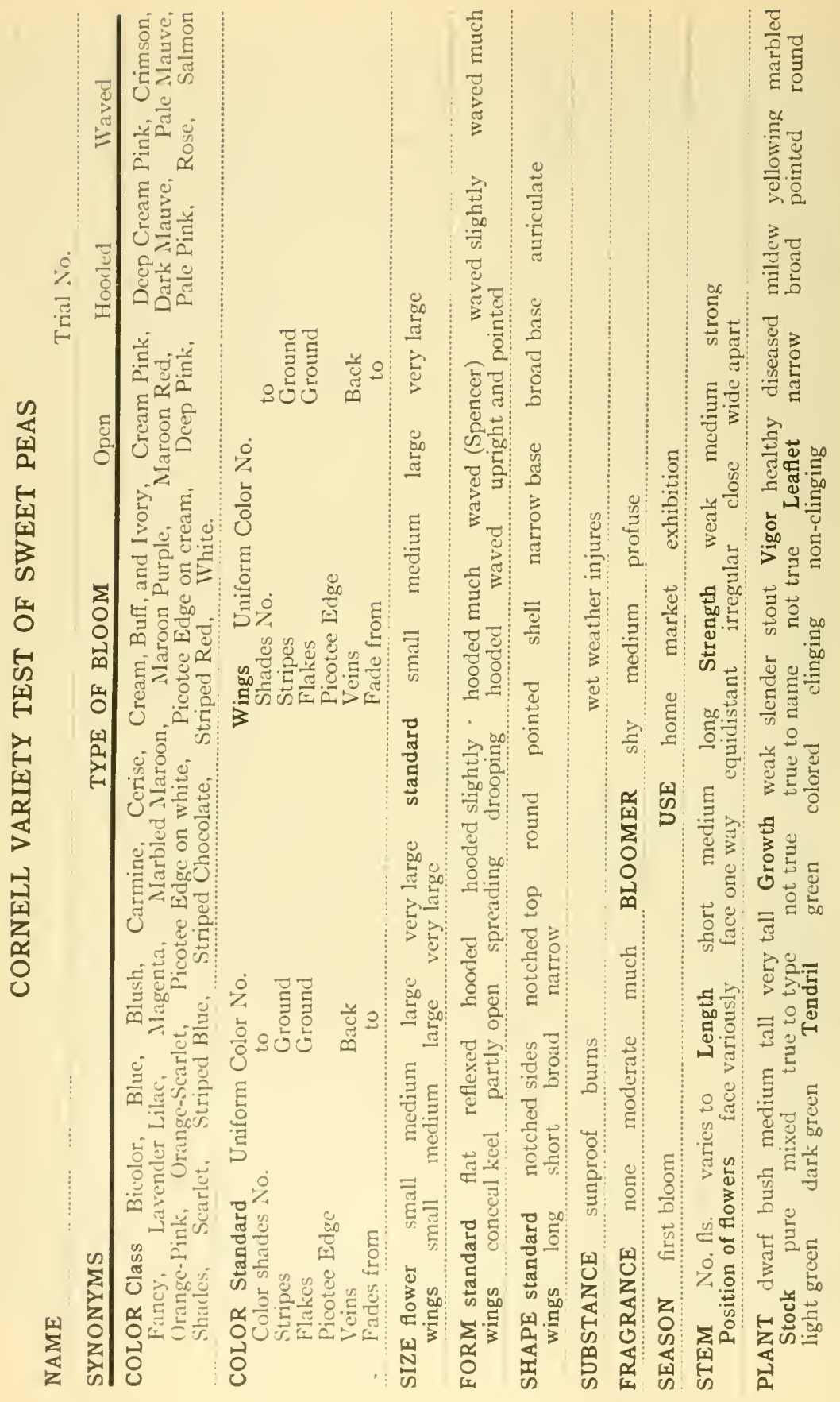




\section{DESCRIPTIONS OF VARIETIES}

\section{OPEN-FORM VARIETIES}

Bicolor (Blanche Ferry group)

\section{BLANCHE FERRY}

Originated by

Introduced by D. M. Ferry \& Co., I 889.

Donated by A. T. Boddington, and W. Atlee Burpee \& Co.

Description in brief - Medium size, red and white, extra early, open form, notched standard.

Description in detail - Color of standard scarlet I56 (3-4); wings lilacy white 7 (4). Flower of medium size, open form; standard of medium size, open form, with notched top; wings long and narrow, concealing the keel. Flowers two to three, on short to medium stems. Very fragrant. Bloom profuse, lasting well on the plant. Sunproof. A garden or market variety. Plant of short, slender growth. Leaflets narrow, pointed, dark green. Seed black, large.

Comparison - Extra Early Blanche Ferry, Earliest of All, Reselected Extreme Early Earliest of All, are similar, but earlier. A difference of sixteen days has been noted in the earliness of the varieties of this group.

Remarks - The first and epoch-making variety. The introducer illustrated it with a color plate, the first sweet-pea novelty of American origin thus figured in an American catalogue. For history see Bulletin 320 of this experiment station, page 69I, and Bulletin 3I9, page 625 .

\section{BLUSHING BRIDE}

Originated by

Introduced by Joseph Breck \& Co., I 89 I.

Description in brief - A rose-and-white variety.

Comparison - " Resembles Blanche Ferry in color, but is larger." - Breck's catalogue, I 89 I.

Remarks - Said to be a sport of Painted Lady. Was grown for a time by Boston florists.

\section{BRIDE OF NIAGARA}

Originated by Mrs. O. H. Day.

Introduced by James Vick's Sons, I 896.

Description in brief - A double-flowered strain of Blanche Ferry.

Remarks - Interesting historically as the first double sweet pea. This variety was originated by Mrs. O. H. Day, Niagara Falls, New York, and was announced by Vick in 1896 . The name was selected by ballot. The variety was introduced in I 896, when it was described as having a clear pink banner, and white wings and keel. The flowers often had two or three banners.

\section{EARLIEST OF ALL}

Originated by Thomas Gould.

Introduced by Burpee, I 898.

Donated by Boddington, Burpee.

Description in brief - Flower of medium size, red and white, open form, notched standard; an extra early variety.

Comparison - Color same as Blanche Ferry. Not so vigorous as Blanche Ferry in the field. 


\section{EXTRA EARLY BLANCHE FERRY}

Originated by

Introduced by Ferry, 1895 .

Description in brief - Flower of medium size, red and white, open form, notched standard; an extra carly variety.

Comparison - Similar to Blanche Ferry, but earlier. Blanehe Ferry and Extra Early Blinche Ferry are more vigorous than Earliest of Al?.

\section{FLORENCE FRASER}

Originated by

Introduced by J. C. Vaughan, 1904. Description in brief - l'lower of medium size, red and white, open form.

Comparison - Differs from Blanche Ferry in greater vigor of plant and longer-stemmed flowers.

\section{LADY DALKEITH}

Originated by

Introduced by L. L. May \& Co., I894.

Description in brief - " Red and white, very free flowering." - May's catalogue for 1894. Not listed in later eatalogues.

\section{LITTLE DORRIT}

Originated by Henry Eckford.

Introduced by Eckford, I 895 .

Descriplion in brief - Red and white, open form.

Comparison - Resembles Blanche Ferry, with possible exception of shape of the standard.

\section{NELLIE JANES}

Originated by -..........

Introduced by R. \& J. Farquhar, 1892.

Description in brief - A pink-anci-white varjety.

Synonyms - Painted Lady under another name.

Remarks - Grown by Boston florists.

\section{PAINTED LADY}

Description in brief - Standard rose, wings white tinged with pink.

Comparison - Blanche lerry was introdueed as "Improved Painted Lady."

Synonyms - Nellic Janes is the same as Painted Lady.

Remarks - Catalogued in all old trade lists. Earliest mention by Philip Miller in Gardeners' Dictionary, 1731. Probably the same form as that described by Burmann as Lathyras Zeylanicus, he supposing that it came from Ceylon. Appears to have been omitted in American catalogues since 1899, but in some English lists later than this.

\section{RESELECTED EXTREME EARLY EARLIEST OF ALL}

Originated by Gould.

Introduced by' Burpee, 1902.

Donated by Burpec, Boddington.

Description in brief - Flower of melium size, red and white, open form, notched stanilirel, extra carly.

Comparison - Blanche Ferry, Extra Early Blanche Ferry, and Earliest of All are similar in color of flower and in habit of plant. 
Bicolor (Miscellaneous group)

Originated by

\section{BEACON}

Description in brief - A medium to large, open-form variety, with cerise standard and creamy wings.

Comparison - An improved Duke of York.

\section{BLUE BELL}

Originated by

Introduced by May, I 894 .

Description in brief - Described in Bulletin II of this experiment station as follows:

"Flowers small. Standard convex, wedge-shaped. Color, standard pink, wings purple-rose. Bloom sparse."

Remarks - Catalogued for next five years after introduction.

\section{BRONZE KING}

Originated by

Introduced by Haage \& Schmidt.

Donated by C. C. Morse \& Co., for evolution studies.

Description in brief - A small, open-form variety, with coppery pink standard and white wings.

Description in detail - Color of standard violet-old rose 145 (I); wings creamy white Io (I). Flowers small, open form; standard small, flat, stiff, with notched top; wings long and narrow. Burns badly. Plant of tall, strong growth.

Remarks - Offered by Henderson in 1894.

\section{BRONZE PRINCE}

Originated by Eckford.

Introduced by Eckford (?), Bull, I 885 .

Description in brief - "Flowers large. Standard flat. Color, purple-red, the wings the more purple. "- Bulletin I I of this station.

Synonyms - Iight Blue and Purple is the same variety. Joanna Theresa is the same. Remarks - One of the first of the Eckford varieties, and one that remained in the trade for at least fifteen years. Mentioned in Gardeners' Chronicle [n. s., vol. 20 (I883), p. 264].

\section{COUNTESS OF SHREWSBURY}

Originated by Eckford.

Introduced by Eckford, I 896.

Donated by Morse, for evolution studies.

Description in brief - A small variety, with rosy standard and white wings.

Description in detail - Color of standard violet-rose 154 (I), fading to lilacy white 7 ( 4 ) at the edge; wings lilacy white 7 (I). Flower small, open form; standard small, flat, sometimes reflexed, with apical notch; wings of medium size, upright, and pointed, concealing the keel. Flowers two to three, on medium stems. Fragrance questionable. Bloom moderately profuse, continuous. Standard fades and burns at the top.

Comparison - Lady Beaconsfield is similar, but is on a primrose ground.

Originated by Eckford.

\section{DUKE OF YORK}

Description in brief - Smaller than medium size. Open-form variety, with rose-pink standard, and wings light primrose shaded with pink.

Comparison - Has been described as Blanche Ferry.on a primrose ground. Emily Lynch was the improved form of this variety. 


\section{EMPRESS OF INDIA}

Originaled by Eckford.

Introduced by Eckford, I $89 \mathrm{I}$.

Donated by Morse, for evolution studies.

Description in brief $-\mathrm{A}$ medium-sized, open-form variety, with rosy standard and wings.

Description in detail - Color of standard violet-rose I5t (4), purple-rose $\mathbf{1 5 0}$ (J) on the back; wings mauve-rose 153 ( 1 ), veined with solferino-red $157(3-4)$. Flower of medium size, open form; standard of medium size, flat, with round top; wings long and narrow, concealing the keel. Flowers two, on medium stems. No fragrance. Bloom molerately profuse, continuous. Plant of medium height and slender growth. Leaflets narrow, pointed; tendrils green.

Comparison - Blanche Ferry has wings of a purer white.

\section{GEM}

Originated by

Introduced by May, I 894.

Description in brief - Red and white.

Remarks - Does not appear in later catalogues.

\section{LADY BEACONSFIELD}

Originated by Eckford.

Introduced by Eckford, I 893.

Donaled by Morse, for cvolution studies.

Description in brief $-\Lambda$ medium-sized, open-form flower; standard light pink on primrose, wings light primrose.

Description in detail - Color of standard lilacy white 7 (4) on a yellowish white ground; wings yellowish white I3 (3). Flower of medium size, open form; standard of medium size, flat, with notched top; wings medium to large, long, of medium width, partly open. Flowers two to three, on long, strong stems. Very sweet-scented. Bloom profuse, continuous. Plant of medium to tall, strong growth. Tendrils colored.

Comparison - Countess of Shrewsbury is similar in color but is on a white ground. Coquette is said to be the large, hooded form of Lady Beaconsfield.

Remarks - One of the best of the old varieties.

Originaled by Eckford.

Introduced by Eckford, 1897.

Description in brief $-\Lambda$ large, open-form variety, with rose-colored standards and crimson-pink wings.

Comparison - Sail to be similar to Empress of India, but is much larger. Royal Rose is the hooderl form of this color.

Blue and Purple Shades (Bright blue)

\section{BLUE BELLE}

Originaled by S. Bide \& Sons.

Introduced by

Donated by Bicle, 1912.

Description in brief $-\Lambda$ grandiflora variety, with violet-blue standards and violetpurple wings.

Description in detail - Color of stanclard bishop's violet I89 (I), sometimes marked at base with violet-purple; wings violet-purple 192 (1). Flower of medium size, open form; standard of medium size, flat; wings long, narrow, drooping. Flowers 
two, on slender stems of medium length. Moderately fragrant. Moderately productive. Flower fades, and lasting quality is poor. Plant of tall, slender growth. Leaflets broad.

\section{FLORA NORTON}

Originated by Morse.

Introduced by Vaughan, 1904.

Donated by Boddington, r 9 Io.

Description in brief - A medium-sized flower of a lavender-blue shade.

Description in detail - Color of standard and wings lavender-blue 204 ( $\mathrm{I}$ ); the clearest of the blues. Flower of medium size, open form; standard of medium size, flat, with round top; wings long and broad, partly open. Flowers two, on medium stems. Moderately fragrant. Bloom profuse. Sunproof. A garden variety. Plant of tall, strong growth. Leaves and stems light green; tendrils green.

Remarks - A beautiful blue. Unfortunately the flower is too small for exhibition, but the variety is worthy of retention because of the color. Flora Norton Spencer is not the same color.

Originated by Dobbie \& Co.

\section{MID BLUE}

Donated by Dobbie, I9I0; Burpee, I9II.

Description in brief - A medium-sized, " deep sky blue " flower.

Description in detail - Color of standard bluish violet 203 (2-3); wings lavender-blue $204(2-3)$, the lower edges fading to almost white. Flower medium large, open form; standard medium large, flat, occasionally reflexed in very hot sunshine, with round top; wings long and broad, spreading. Flowers two to three, equidistant on long, strong stems. Very fragrant. Bloom medium. Sunproof. Plant of tall, strong growth. Leaflets narrow, pointed.

Comparison - Practically identical with Zoe (Biffen, Miss Hemus, Unwin, 1906). Standard lighter than that of Lord Nelson and darker than that of Flora Norton.

\section{ZOE}

Originated by R. H. Biffen. Introduced by Biffen, Miss H. Hemus, W. J. Unwin, I 906. Comparison - Practically identical with Mid Blue (Dobbie), and has prior introduction.

\section{Blush}

Originated by Eckford.

Introduced by Eckford, I 895 .

Donated by Morse.

Description in brief - Pink and buff, shaded on white.

Description in detail - Color of standard pale rosy pink 129 (I); wings lilacy white 7 (I).

Flower small, open form; standard small, flat or with reflexed edges, with notched top; wings very long, longer than standard, narrow, concealing the keel. Flowers two to three, usually three, on medium stems. Bloom profuse, continuous. Flowers burn badly, and last poorly while on the plants. Plant of medium height and slender growth. Leaflets narrow, pointed.

Comparison - Sensation is the large, hooded form of this variety.

Remarks - Too small for the present day. 


\section{DELIGHT}

()riginated by Eckford.

Introduced by Eckford, I 889.

1): nuled by Morse, for evolution studies.

Description in brief - A small, open-form, light blush variety.

Description in detail - Color of standard and wings creamy white Io (I), usually with the faintest tinge of pink; millrib on back of standard pink. Flower small, open form; stanclard small, flat, with notched top, folded; wings long and] narrow, partly open. Flowers two, on medium stems. Moderately fragrant. Bloom profuse, continuous. Burns slightly. Plant of medium height and slender growth. Leaflets narrow, pointel; tendrils green.

Comparison - Lemon Qucen resembles this in color, but is larger.

\section{FAIRY QUEEN}

Originated by

Introduced by Hatage \& Sehmidt, I $8 ; 2$.

Donated by Morse, for evolution studies.

Description in brief - I small, open, rosy white variety.

Description in detail - Color of stanclard rosy white 8 (r), with a few lines of bright rose 128 (I); wings rosy white. Flower small, open form; standard small, flat or with reflexed edges, with notehed top; wings short and broad, partly open. Flowers two, on long stems of moderate strength. Very fragrant. Bloom profuse, continuous. Burns badly. Plant of medium height and slender growth. Tendrils green.

Remarks - ()ne of the oldest varieties. In the American trade from I 882 until i 899 .

Originated by Eckford.

Introduced by Eckford, I892.

Donated by Morse, for evolution studies.

Description in brief - A pale blush, lemon-tinted variety.

Description in detail - Color of standard ereamy white Io (I); wings milk white II (I); general effect white. Flower of medium size, open form; standard of medium size, flat, with notched top, looped so as to conceal the notch; wings long, broad, concealing the keel. Flowers two to three, usually two, on long, strong stems. Bloom profuse, continuous. Burns badly. Plant of medium height and slender growth. Leaflets narrow, pointed; tendrils colored.

Comparison - Delight is similar in color, but is smaller.

Remarks - If this variety did not burn it would be desirable even at the present day.

\section{MISS ETHEL}

()riginated by Eckford.

Introduced by Eckford, I 885 .

Description in brief - Delicate pink, with blush wings.

Remarks - This variety was offered ly Henderson in 1886,1887 , and 1888 . by Breck in 1886 , and by Farquhar in 1887 .

\section{MRS. GLADSTONE}

Originated by' Eckford.

Introduced by Eckford, I890.

Description in brief - Standard light pink, with lighter edges; wings light blush. A medium-sizel, open-form varicty.

Comparison - Princess Beatrice is deeper-colored. Katherine Tracy is larger and deeper-colored. 
Carmine and Rose (Carmine group)

Originated by

\section{DOROTHY VICK}

Donated by Morse, for evolution studies.

Introduced by Vick, I 897 .

Description in brief - A double flower, with scarlet standard and purplish crimson wings.

Description in detail - Color of standard scarlet I 56 (2); wings purplish crimson I 57 (I). Flower small to medium, open form, occasionally double; standard small to medium, reflexed, with narrow base; wings short and broad, partly open. Sub. stance poor. Flowers two to three, usually two, on medium stems. Burns badly. Plant of medium height, but makes a heavy growth. Tendrils colored; color in axils of leaves and leaflets.

Comparison - A strain of Duchess of Edinburgh producing double flowers. White Wonder or Double Duke of Clarence gives a higher percentage of doubles. White Wonder is the best double of the old types.

\section{DUCHESS OF EDINBURGH}

Originated by Eckford.

Introduced by Eckford, 1886.

Donated by Morse, for evolution studies.

Description in brief - A small, open-form flower, with scarlet standard and purplish crimson wings.

Description in detail - Color of standard scarlet I56 (2-3); wings purplish crimson

I57 (2). Flower small, open form; standard small, flat; wings long and narrow.

Moderately productive. Plant short.

Comparison - Princess Victoria is superior in size of flower and in profusion of bloom.

\section{PRINCE EDWARD OF YORK}

Originated by Eckford.

Introduced by Eckford, I 897 .

Donated by Burpee, I910, I9II.

Description in brief - A medium-sized flower, with carmine-purple standard and rose wings.

Description in detail - Color of standard carmine-purple I56 (I); wings Tyrian rose I 55 ( I ). Flower of medium size, open form; standard of medium size, with reflexed edges, round top, and broad base; wings long and broad, concealing the keel. Flowers two to three, on strong stems of moderate length. Moderately fragrant. Plant of medium height and strong growth. Tendrils green.

Comparison - Similar to Princess Victoria, but superior.

\section{PRINCESS VICTORIA}

Originated by Eckford.

Introduced by Eckford, I 891 .

Donated by Morse, for evolution studies.

Description in brief - A medium-sized, open-form flower, with scarlet standard and purplish crimson wings.

Description in detail - Color of standard carmine-purple I56 (2-3); wings purplish crimson 157 ( I). Flower of medium size or larger, open form; standard of medium size, flat, with notched top and apical fold; wings long and broad. partly open. Flowers two to three, on long, strong stems. Burns slightly in hot sunshine. Plant of medium height and slender growth. Leaflets narrow, pointed; color in the axils; tendrils colored. 
Comparison - Color is similar to that of Dorothy Vick, but the flowers are larger and have longer stems.

Carmine and Rose (Rose group)

Originated by

\section{ADONIS}

Introduced by James Carter \& Co., I 882.

Description in brief - A meclinm-sized flower, with rosy pink stanclard, and wings of lighter shate.

Description in detail - Color of standard purple-rose 150 (2); wings mauve-rose I 53 (I). Flower of merlium size, open form; standard of medium size, flat or reflexed, with notelecl top and apical fold; wings long and broad, concealing the kecl. Flowers two, irregulitrly placed on long, medium stems. Moderately fragrant. Bloom profuse, continuous. Burns badly. Plant of tall, slender growth. Tendrils green.

Comparison - Novelty and Miss Hunt are similar in color. but are larger.

Remarks - Burpee offered this variety in 1884 , Breck in 1885 .

\section{AMERICAN QUEEN}

Originated by Morse.

Introduced by Burpee, 1902.

Description in brief - Large, open form, magenta-rose self.

Comparison - Lord Kenyon and Lord Roseberry are similar in color, but are of hooded form.

\section{MIMA JOHNSTON}

Originated by Eckford.

Introduced by Eckford, I908.

Description in brief - "Bright rose carmine, shaded salmon, wings soft rose."Eckford's catillogue.

Comparison - Morse considers this variety an open form of Bolton's Pink, of medium size.

Originated by Eckford.

\section{MISS HUNT}

Donated by Morse, for evolution studies.

Description in brief - A medium-sized, open flower, rosy pink.

Description in detail - Color of standard lilac-rose $152(2-3)$; wings violet-rose $15+$ $(2-3)$; back a trifle deeper-colored. Flower of medium size or larger, open form; standard medium to large, flat, with notehed top; wings long and broad, concealing the keel. Flowers two to three, on long, strong stems. Bloom profuse, continuous. Burns slightly. l'lint slencler. Leaflets narrow, pointed; tendrils green. Comparison - Larger, brighter, better-shaped flowers than Adonis. A little lighter than Novelty. ()vid, Lord Kenyon, and Lord Roseberry are the hooded forms of this variety.

Remarks - Offerel by Henderson in 1889.

Originated by Eckford.

Introduced by Eckford, I 895 .

Donated by Morse, for evolution studies.

Description in brief - $\Lambda$ medium-sized, rosy scarlet flower.

Description in detail - Color of standard lilac-rose 152 (4); wings violet-rose I 5t (4). Flower of medium size, open form; standard of medium size, flat; wings long and 
broad, concealing the keel. Flowers two to three, on very long stems of medium strength. Bloom moderately profuse. Burns slightly. Plant of medium height and slender growth. Leaflets narrow, pointed, dark green; pedicels red.

Comparison - A little deeper-colored flower than Miss Hunt; a distinct plant, with darker green leaves, less vine, and less profuse bloom than that variety.

\section{Cream-Pink}

Originated by Eckford.

\section{AGNES JOHNSON}

Donated by Morse, 1910.

Introduced by Eckford, 1903 .

Description in brief -A medium-sized flower; standard cream shaded with rose-pink, wings cream flushed with pink.

Description in detail - Color of standard pale blush 137 (4); wings mauve-rose 153 ( $1-2$ ). Flower of medium size, open form; standard of medium size, flat, with round top; wings long and broad, concealing the keel. Flowers two to three, on long, strong stems. Moderate fragrance. Bloom moderate. Plant of tall, strong growth. Leaves pointed; tendrils green.

Comparison - Very similar to Sunrise and Evening Star, but larger.

\section{CORONATION}

Description in brief - Blush, with pink at the back of the standard.

Comparison - Similar to Duchess of Westminster.

\section{DUCHESS OF WESTMINSTER}

Originated by Eckford.

Introduced by Eckford, I900.

Description in brief - Apricot tinged with pink, which is deepest at the base of the standard; wings delicate rose-pink.

\section{EVENING STAR}

Originated by Morse.

Introduced by Vaughan, I904.

Donated by Vaughan, I9IO.

Description in brief - "A pale buff flushed salmon pink." - Vaughan's catalogue.

Description in detail - Color of standard maize yellow 36 (I) on a violet-rose I 54 (3) ground; wings mauve-rose I53 ( $\mathrm{I}$ ). Flower of medium size; standard of medium size, flat, with round top; wings long and broad, concealing the keel. Flowers two to three, on long, strong stems. Bloom moderate. Plant of tall, strong, healthy growth. Tendrils green.

Remarks - Morse states that before its introduction this variety was called Openform Venus.

\section{MAY PERRETT}

Originated by Eckford.

Introduced by Eckford, 1908.

Description in brief - Ivory, flushed with buff or creamy pink.

Remarks - See May Perrett Spencer.

\section{SUNRISE}

Originated by Morse.

Introduced by Vaughan, I904.

Donated by Vaughan.

Description in brief - Bright pink suffused with primrose. 
Description in delail - Color of standard and wings mauve-rose I53 (I-2); standard flushed with violet-rose i5t (4). Flower of medium size; standard of medium size, flat, with notched top; wings long and broad, partly open. Flowers two, sometimes three, on good stems. Moderate fragrance. Bloom profuse. Burns slightly in hot sun. Plint of tall, stout growth. Leaflets narrow, pointed.

Remarks - Mlorse states that before its introduction this variety was called Katherine 'racy on cream.

\section{ZARINA}

Originated by Biffen.

Introduced by Miss Hemus, 1909.

Donated by Miss Hemus, 1910.

Description in brief - A beatififul, large, decorative flower, of open form and soft salmon-pink color.

Description in detail - Color of standard pale rosy pink $129(1-2)$; wings pale lilac-rose I 30 $(1-2)$ on a buff ground. Standard open, sometimes slightly waved; wings short and narrow. Flowers two to three, on fairly strong stems. Moderately fragrant. Bloom very profuse, continuous. Many double and triple standards. Plant of short, slender growth. Leaflets narrow, pointed; tendrils numerous and very much colored; color in axils of leaves and leaflets; calyx dark reddish brown. Comparison - Queen of Spain in open form.

Remarks - A true stock.

Crimson and Scarlet (Crimson group)

Originated by Eckford.

\section{CARDINAL}

Donaled by Morse, for evolution studies.

Description in brief - A medium-sizel, open-form, scarlet-crimson variety.

Synonyms - Sime as Carmine Invincible at this station. Captain Sharkey (Breck, I 889 ) is the same variety. (See Bulletin I 27 of this station.)

Remarks - Nthough J. S. Eckford states that this was introduced in 1887 , the writer finds Cardinal (Eckford) catalogued by Breck in 1886. In Breck's catalogue for 1887 is found Cardinal (Eckford, I886).

\section{CARMINE INVINCIBLE}

Originated by Thomas Laxton.

Introduced by Laxton, I 886.

Donated by Morsc, for evolution studies.

Description in brief $-\Lambda$ medium-sized, open-form, scarlet-crimson variety.

Description in detail - Color of standard claret 167 (2-3); wings dull dark crimson I68 (1). Flower smaller than medium size, open form; standard of medium size, with edges reflexed, sometimes twisted or curled; wings long and broad, usually concealing the keel. Substance poor. Flowers two to three, on short, weak stems. Fragrant. Bloom profuse and continuous. Burns badly. Plant of medium height and stender growth. Produces many side branches from the base, giving a heavy row of plants.

Renarks - This variety marked a distinct advance in the improvement of sweet peas. Reputed to be a cross between Invincible Scarlet and Invincible Black. Received an award of the Filoral Committee of the Royal Horticultural Society in $\mathbf{1} 883$. 


\section{FIREFLY}

Originated by Eckford.

Introduced by Eckford, I 893 . Description in brief - A medium-sized, open-form, bright red variety. Comparison - Slightly different form from Cardinal. Ignea, Brilliant, Mars, Salopian, and King Edward VII were the hooded forms of this color. King Edward Spencer is the waved form.

\section{INVINCIBLE SCARLET}

Originated by Stcphen Brown.

Introduced by Carter, I 866.

Description in brief - A crimson-scarlet variety.

Synonyms - Morse states that this is the same as Carmine Invincible.

Remarks - On July II, I865. Mr. Brown gained the first First Class Certificate ever awarded by the Royal Horticultural Society for a sweet pea. This variety was catalogued in the American trade from 1870 until 1900.

\section{KING EDWARD IMPROVED}

Originated by

Introduced by Watkins \& Simpson, I9 I0.

Donated by Watkins \& Simpson.

Description in brief - A large, carmine-scarlet variety.

Comparison - An improved strain of King Edward VII.

Remarks - A fixed stock.

Originated by Eckford.

KING EDWARD VII

Donated by Boddington, I910; Burpee, 19II, I912.

Description in brief - A large, carmine-scarlet variety.

Description in detail - Color of standard carmine-purple 156 (4); wings carmincpurple $156(1-2)$. Flower large, open form; standard large, flat or occasionally slightly hooded; wings large, long and broad, concealing the keel. Substance good. Flowers three to four, on long, strong stems. Fragrance very slight or none. Bloom profusc, continuous. No burning. A garden or market variety. Growth tall, strong, and healthy.

Remarks - This variety represents the acme of the crimson-scarlet varieties of the open or the hooded form. King Edward Spencer is the waved form.

Crimson and Scarlet (Scarlet group)

\section{BAKER'S SCARLET}

Originated by

Introduced by Baliers, 1909.

Description in brief - "Almost pure scarlet. Same shade as Queen Alexandra but not so well formed as standard turns backward."- Morse's Field Notes on Sweet Peas. Comparison - Introduced as an Improved Qucen Alexandra.

\section{FADELESS SCARLET GEM}

Originated by Morse.

Introduced by Morse, 1907 .

Donated by Morse, rigro.

Description in brief - A bright scarlet variety.

Description in detail - Color of standard and wings French purple I6I (I-2). This strain of Scarlet Gem does not turn purple. Flower of medium size, open form; 
stanclard of merlium size, flat, with rouncl top; wings long and broad, concealing the keel. Flowers two to three, 11stially two, on long, strong stems. Bloom profuse, continuous. A garden variety. Plant of medium height and slender growth. Poliage of a bluish green color.

Remarks - Is not farleless; it soon loses its bright appearance, but is free from the objectionable purple tinge in the original variety.

\section{SCARLET GEM}

Originated by Eckford.

Introduced by Eckford, I904.

Donated by Burpec, I9I.

Description in brief - A bright scarlet variety.

Description in detail - (See the description preceding, of Fadeless Scarlet Gem.)

Comparison - Fadeless Scarlet Gem is supposed to be a better selection. No difference was seen in the trials at this station in 1911 .

Remarks - Unfortunately the flower turns dark soon after it opens, becoming almost black.

\section{W. E. GLADSTONE}

Originated by

Introduced by May, 1894 .

Description in brief - " Brightest shade of scarlet." - May's catalogue, 1894.

\section{Fancy}

Originated by Eckford.

\section{SYBIL ECKFORD}

Donated by Morse, 1910; Burpee, 1911.

Description in brief - $\Lambda$ large, creamy white variety.

Description in detail - Color of standard and wings creany white 10 (3). Flower large, open form; standard large, flat, oceasionally with notched top; wings large, spreading. Flowers two, irregularly placed on medium stems. Moderate fragrance. Moderately productive. Plant of tall. moderately strong growth.

Comparison - An open-form Marchioness of Cholmondeley.

\section{Lavender}

Originaied by Morse.

\section{CREOLE}

Donated by Morse, 1910.

Description in brief - A variety with pinkish lavender standard and lavender wings.

Description in defail - Color of standard pale light lilac 187 (4); wings heliotrope 188 (1), with back of ageratum blue 201 (1). Flower large; standard large, flat; wings large, long and broal. Flowers two to three, usually three, on medium stems. Very frigrant. Bloom profuse, continuous. Plant of strong, tall growth.

Remarks - Not more than fifty per cent true. Morse states, however, that the variety was withilritwn because of the impossibility of getting it more than seventy-five per cent true.

\section{PRINCESS MAY}

Originaled by laxton.

Introduced by Laxton. 1893 . Description in brief $-\Lambda$ variety with pale mauve standard and lavender wings. Flower of merlium size.

Comparison - Superseded by Lady Grizel Hamilton.

Remarks - Offered in the United States by Henderson in 1894. 


\section{Magenta-Rose}

Originated by Eckford.

\section{CALYPSO}

Description in brief - A magenta-flushed and -veined mauve flower, of medium size and open form.

\section{Marbled}

Originated by

\section{AZURE FAIRY}

Description in brief - " French grey ground marbled pale blue." - Bath's catalogue. Remarks - When grown in I9Io this variety was very unfixed. The majority of our plants were Helen Pierce, with a few David R. Williamson. TVe believe this variety has been improved.

\section{HELEN PIERCE}

Originated by Morse.

Introduced by Morse, 1905 .

Description in brief - White-veined, mottled and marbled with bright blue.

Description in detail - Standard marbled and flaked with bluish violet 203 (3) on a purplish-tinted white ground $6(3-4)$; wings lilacy white $7(3-4)$; base of petals not colored; back of standard heavily marbled with blue; lower edges of wings and base of standards often fleshy white $9(\mathbf{I}-2)$. Flower of medium size, hooded form; standard of medium size, hooded slightly, with round top; wings long and broad, partly open. Flowers two to three, on long, strong stems. Moderately fragrant. Bloom profuse, continuous. Sunproof. Plant of medium height and strong growth.

Remarks - Distinct. One of the indispensable varieties for a complete collection.

Maroon Shades (Claret group)

\section{CARMEN SYLVA}

Originated by Laxton.

Introduced by Laxton, I 892 .

Donated by Morse, for evolution studies.

Description in brief - Standard claret at base, shading to almost white edges; wings lilac.

Description in detail - Color of standard carmine II6 (I), becoming lighter toward edges, which are rosy white $8(2-3)$; wings lilac I76 (4), edges lobelia blue 205 ( 1 ). Flower small, open form; standard small, flat, with narrow base and notched top; wings short and narrow. Flowers two to three, generally two, equidistant on medium stems. Very fragrant. Moderately productive. Burns slightly. Plant of tall, fairly strong growth. Leaflets narrow, pointed; tendrils green.

\section{ETNA}

Originated by Laxton.

Introduced by Laxton, I $\$ 92$.

Donated by Morse, for evolution studies.

Description in brief - Standard amaranth-red, with light edges; wings rosy magenta. Description in detail - Color of standard amaranth-red 168 (4), back purple-brown I66 (3-4); wings rosy magenta I69 (I). Flower small, open form; standard small, flat, with narrow base; wings long and narrow. Flowers two, sometimes three, on slender stems of medium length. Plant of strong, vigorous growth.

Comparison - Vesuvius is much the same, but is more blue.

Remarks - One of the most famous of Laxton's varieties. 


\section{RISING SUN}

Originuted by latxton.

Introduced by Laxton, 1892.

Donated by Morse, for ewolution stulies.

Description in brief - Standard carmine-purple, with rosy white edges; wings mituve-rose.

Description in detail - Color in center of standard carmine-purple 156 (2), with edges rosy white $\&(t)$; wings mauve-rose 153 (1) to violet-rose 154 (I). Flower small, open form: standard small, reflexed, with notched top; wings long, very narrow, partly open. Moderately fragrant. Moderately productive. Burns badly. Stems short and weak. Plant of short, weak, slender growth. Leaflets narrow, pointeri.

Remarks - ()ne of the worst varietics to burn in hot weather.

\section{VESUVIUS}

Originated by J. C. Schmidt.

Introduced by Schmidt, I886.

Donated by Mlorse, for evolution studies.

Description in brief - Color of flower magenta and violet-purple.

Description in detail - Color of standard magenta $182(3-4)$, and rosy white $8(4)$ at the edges; wings hishop's violet (purple) I 89 ( 4 ), and bright violet-purple on the back. Flower small, open form; standard small, flat, stiff, notched; wings long and narrow. Bloom profuse. Plant of tall, strong growth.

Comparison - Carmen Sylva is similar, but is more carmine.

Remarks - Offered by Joseph Breck in 1887 ; hy Farquhar in 1886

Maroon Shades (Maroon group)

\section{BLACK KNIGHT}

Originated by Eckford.

Introduced by Eckford, I 898 .

Donaled by Bodldington, i910; Burpee, r9 I0.

Descriplion in brief - A very deep maroon.

Description in detail - Color of standard nearest to rich pansy-violet I9I (4), but with more red than 19I; wings rich pansy-violet I9I (1-2), veins darker. Back of standard is glossy. Flower large, open form; standard large, flat, with notehed top; wings long and broal, concealing the keel. Flowers two to three, usually two, on stems of moderate length. Fragrance slight. Moderately productive. Plant of tall, strong growth. Leaflets narrow, pointed; tendrils green; pods green. Remarks - (Ine of the darkest varicties, and the lest of its color in the old type.

\section{BLACK MICHAEL}

Originated by Eckford.

Introduced by Eckford, 1905 .

Donated by Bollington, 1910; Burpee, 1911.

Description in brief - A large, pure maroon self.

Description in delail - Color of stanclard deep carmine-violet $17+(3-4)$; wings a little lighter. Flower large, open form; standard large, edges reflexed, round top with loop; wings long and broad, concealing the keel. Flowers two, seldom three, on long, strong stems. l'lant of medium height and slender growth. Leaflets narrow, pointed, dirk green; the entire plant has a blue cast; pods colored on the edge.

Comparison - (jeneral effect similar to Black Knight.

Synonyms - Regina, introducel as an Improved Black Nichacl, appears to be the sine. 
Originated by Eckford.

\section{BOREATTON}

Description in brief - A deep maroon self, with a medium-sized, open-form flower.

Comparison - This variety is a little lighter than Stanley. Boreatton, Stanley, and Black Knight form a series with gradually deepening color.

\section{CARDINAL WOLSELEY}

Originated by

Introduced by May, 1894 .

Description in detail - In Bulletin I I I of this station this variety is described as follows:

" Flowers large. Standard flat, slightly wedged. Color, standard crimson, wings maroon, rich. Bloom somewhat profuse."

Remarks - Shown in color illustration on back cover of May's catalogue for 1895 . The introducer called the color a deep crimson.

\section{EMPRESS OF INDIA}

Originated by

Introduced by May, 1894 .

Description in brief - " Darkest shade of purple."- May's catalogue.

Originated by Bolton.

\section{REGINA}

Donated by W. W. Rawson \& Co., I9ro.

Description in brief - A dark maroon self.

Synonyms - Seems to be Black Michael. Bolton called this variety an improved

Black Michael.

Originated by Eckford.

\section{STANLEY}

Donated by Burpee, I9II.

Description in brief - A large, open-form, deep maroon self.

Comparison - Is deeper-colored than Boreatton. but not so dark as Black Knight.

Remarks - Reputed to be a cross between Captain of the Blues and Splendour.

Maroon Shades (Maroon and Violet group)

\section{BLACK}

Donated by Morse, for evolution studies.

Description in brief - A medium-sized, dark violet variety.

Description in detail - Color of standard dark violet 193 (4); wings rich pansy-violet I9I (1), back I9I (4). Flower of medium size, open form; standard of medium size, flat, with narrow base and notched top; wings long and narrow. Bloom profuse. Plant of tall, strong growth.

Synonyms - Invincible Black is the same variety.

Remarks - One of the oldest varieties. Mentioned in sweet-pea literature as early as 1793 , and catalogued by Thorburn of New York in 1824.

\section{NEGRO}

Originated by Introduced by H. J. Jones, 1908.

Description in brief - Deep maroon and dark blue flower. 


\section{PEACOCK}

Originated by

Introduced by Jones, 1908.

Description in brief - Standard red, wings blue.

\section{SULTAN}

Originated by

Introduced by Laxton.

Description in brief - Standard maroon; wings lilac, bordered with blue.

Comparison - Superseded by Monarch.

\section{Mauve}

Originated by Eckford.

\section{CAPTIVATION}

Donated by Burpee, 1910, 1911, 1912.

Description in brief - A medium-:ized, purple-magenta variety.

Description in detail - Color of standard and wings bluish lilac 183 (2-3); wings a

lighter tint. Flower of medium size, open form; standard of medium size, irregular, sometimes crumpled, with round top: wings long and broad, concealing the keel. Flowers two to three, on long, strong stems. Very fragrant. Bloom profuse, continuous. Burns slightly. Plant of medium height and strong growth. Leaflets broad, pointed; pedicels red; calyx often colored.

Remarks - A distinct variety.

\section{PRINCESS LOUISE}

Description in brief - Standard light magenta-pink, wings lilac.

Synonyms - Hutchins gave this as a synonym of Violet Queen in his catalogues for I $894, \mathbf{1} 895, \mathbf{I} 896$, and $\mathbf{1} 897$.

Remarks - Offered in United States by Burpee in $\mathbf{1} 887$, and listed each year until $\mathbf{I} 898$.

Burpee published a color plate of Princess Louise, Invincible Carmine, and Bronze

Prince in his catalogue for $\mathbf{1} 887$. This is the first color plate of sweet peas in an American catalogue.

Originated by Eckford.

\section{THE QUEEN}

Donated by Morse, for evolution studies.

Description in brief - A small flower, purplish mauve.

Description in detail - Color of standard and wings purplish mauve $186(2-3)$. Flower below medium size, open form; standard below medium size, flat, with slightly notched top; wings long and narrow, partly open. Flowers two to three, equidistant on stems. Fragrance moderate. Bloom profuse. Burns badly. Plant of tall, moderatcly strong growth. Leaflets narrow, pointed; tendrils green.

Comparison - Violet Queen is deeper and more blue.

Remarks - An unattractive variety.

\section{VIOLET QUEEN}

Originated by

Introduced by Carter, $18 ; 8$.

Donated by Morse, for evolution studies.

Description in brief - A small, open flower; standard vinous-mauve, wings violetpurple.

Description in detail - Color of standard vinous-mauve I $8+(2-3)$; wings bright violetpurple $190(\mathrm{I})$, becoming more blue as flower withers. Flower small, open form; 
standarl small, flat, wedge-shaped, with notcherl top and narrow base; wings long and narrow. Flowers two to three. Bloom profuse. Burns badly. Plant of tall, moderately strong growth. Leaflets narrow, pointed.

Comparison - The Queen is similar, but lighter. Emily Eckford is the perfected form.

Remarks - Messrs. Carter advertised this variety by means of a colored plate in their catalogue. This was the first sweet pea so figured. Henderson offered it to the American trade in 1882 .

Drange Shades (Orange-pink group)

\section{EVELYN BYATT}

Originated by

Introduced by Watkins \& Simpson, 1906.

Description in brief - A brilliant scarlet-orange variety.

Description in detait - Color of standard reddish old rose I42 (4); wings old rose $\mathrm{I}_{44}$ (I), back purple-rose 150 (I). Flower of medium size, open form; standard of medium size, flat, without apical notch; wings large, long, nearly as long as standard, broad, partly open. Flowers two to three, usually three, on long, strong stems. Bloom profuse. Burns very badly. Plant of tall, strong growth. Leaves narrow, pointed; tendrils green.

Comparison - More attractive than Gorgeous.

\section{HERBERT SMITH}

Originated by Holmes.

Introduced by Robert Sydenham, 1908.

Description in brief - Orange-pink in color.

Comparison - Introduced as an Improved Gorgeous.

Orange Shades (Orange-scarlet group)

\section{COUNTESS OF POWIS}

Originated by Eckford.

Introduced by Eckford, I 897.

Description in brief - "Glowing orange suffused light purple."- Originator's description, catalogue, I 897 .

\section{GORGEOUS}

Originated by Morse.

Introduced by Burpee, I 899.

Donated by Burpee, I910, I911.

Description in brief - A medium-sized variety. Standard orange-scarlet; wings rose, tinged with orange.

Description in detail - Color of standard reddish old rose $\mathbf{I}_{42}(4)$; wings bright rose I 28 (I), strongly tinged with orange. Flower of medium size, open form; standard of medium size, flat; wings short and broad, partly open. Fragrance slight. Bloom profuse. Burns badly. Stems medium in length and strength. Plant of medium height and strong growth.

Comparison - A deeper and brighter color than Countess of Powis, Meteor, and Orange Prince, which form a series in the order named.

\section{HETTY GREEN}

Originated by H. E. Ward.

Introduced by Bolton, I907. Description in brief - "Bright orange scarlet, wings rosy crimson." - Catalogue of National Sweet Pea Society. 


\section{METEOR}

Originated by Eckford.

Donated by Morse, for evolution studies.

Description in brief - Oringe-pink, wings orange-rose.

Description in detuil - Color of standard rosy flesh $134(2-3)$; wings violet-rose 154 (I).

Flower of medium size, open form; standard of medium size, flat; wings long and

broad. Flowers $t$ wo, on short or medium stems. Fragrant. Bloom profuse, continuous. Burns badly. Plant of medium height.

Comparison - A slightly deeper color than Orange Prince.

\section{MILDRED WARD}

Originated by Ward.

Introduced by Sydenham. 1907.

Description in brief - An orange-scarlet variety.

\section{ORANGE PRINCE}

Originated by Eckford.

Introduced by Eckford, i 886.

Donaled by Morse, for evolution studies.

Description in brief - " A bright orange pink."- - Hutchins' catalogue.

Description in detail - Color of standard rosy flesh I3+ (1); wings violet-rose I54 (I). Flower of medium size, open form; standard of medium size, reflexed, sometimes crumpled, with notched top; wings large, long and broad. Flowers two, on strong stems of medium length. Burns badly. Plant of medium height and slender growth. Leaflets narrow, pointed.

Remarks - Received award by Floral Committee of the Royal Horticultural Society in 1883. Offered in United States by Breck in 1887 .

Picotee Edged (Lavender and Mauve group)

\section{BLUE EDGED}

Originated by Major Trevor Clarke.

Introduced by Carter, 1860.

Synonyms - Blue Hybrid was probably identical.

Remarks - This variety is given in the Sweet Pea Annual, and in Sweet Peas Up to Date (edition of 1910 ), as first introduced in 1883 . This is an error of date. The varicty was catalogued by Vick as early as $18 \% 2$, if not earlier. The first of the picotee-edged blues.

\section{CAPTAIN CLARKE}

Originated by

Introduced by C. Sharpe \& Co.

Description in briff - White-edged and penciled with carmine; wings edged with blue. Description in detail - Color of standard shaded violet-rose $15+(2-3)$ on a lilacy white 7 (4) ground; wings lilacy white, shaded lilac-mauve 196 (I). Flower small, open form; standard small, flat, with notched top; wings short and broad, partly open. Flowers two to three, usually three, equidistant on medium stems. Mloderately fragrant. Bloom profuse. Plant of tall, healthy growth. Leaflets broad, pointed; tendrils green.

Remarks - Formerly known also under name "Tricolor." Columbia, another tricolor varicty, is striped. (Offered by Breck in 1885 . 


\section{SPLENDID LILAC}

Donated by Morse, for cvolution studies.

Description in brief - A medium-sized flower, with a lilac-blue standard, and white wings edged with blue.

Description in detail - Color of standard bltish lilac I83 (4), back I83 (I); wings white, edged and shaded with ageratum blue $20 \mathrm{I}(\mathrm{I}-4)$. Flower of medium size, open form; standard of medium size, flat, wedge-shaped, with narrow base and notched top; wings long and narrow. Flowers one to two, sometimes only one, on short stems. Plant of very tall, strong growth. Leaflets narrow, pointed, dark green.

Remarks - An unattractive variety, due to poor contrasts in color. Offered by Burpee in 1887 .

\section{Pink}

\section{BRIDESMAID}

Originated by Morse.

Introduced by Vaughan, 1904.

Description in brief - A medium-sized, deep pink variety.

Description in detuil - Color of standard mauve-rose I53 (I), center violet-rose I 54 (3); wings mauve-rose 153 (I). Flower of medium size, open form; standard of medium size, flat, with notched top; wings short, partly open. Flowers two, on medium stems. Bloom profuse. Plant of tall, strong, healthy growth. Leaflets broad, pointed; tendrils green; no axillary color shown.

Comparison - A deeper color than Katherine Tracy, but otherwise similar. Bridesmaid was an improvement on Princess Beatrice.

\section{CROWN PRINCESS OF PRUSSIA}

\section{Originated by}

Introduced by Haage \& Schmidt, I 868-I 869.

Donated by Morse, for evolution studies.

Description in brief - Light rose, shading deeper toward center.

Description in detail - Color of standard shading from mauve-rose 153 (I) to rosy white 8 (I); wings mauve-rose I53 (I); color is deeper at base of standard and on dorsal edges of wings. Flower small, open form; standard small, badly reflexed, with notched top; wings long and narrow, partly open. Flowers two to three, on long stems of medium strength. Moderately fragrant. Moderately but continuously productive. Burns badly. Plant of medium height and slender growth. Leaflets narrow and pointed; tendrils green.

Comparison - Colors weaker than those of Peach Blossom.

Remurks - Catalogued by C. Platz, of Erfurt, in 1870. Distributed in England by Sharpe in 187 . Probably the first of the pink varieties.

\section{DUCHESS OF MARLBORO}

Originated by

Introduced by May, 1894 .

Description in brief — " A rich rose color."- May's catalogue.

Description 2 in detail - In Bulletin III of this station the variety is described as follows: "Flowers small. Standard flat. Color, standard pink, wings rose-pink. Bloom profuse."

Remarks - A colored illustration of this variety appeared on the back cover of May's catalogue for I 895 . 


\section{DUKE OF KENT}

Originated by

Introduced by May, 1894 .

Description in detuil - In Bulletin $11 \mathrm{t}$ of this station is the following description

of this variety: " Nlowers small. Stanilard flat, wedge-shape. Color, rose-pink.

Bloum medium."

Remarks - Introducer gives color as a beautiful carmine.

\section{ISA ECKFORD}

Originated by Eckford.

Introduced by Eckford, 1887.

Description in brief - Creamy white, suffused with rosy pink.

Comparison - Peach Blossom is the larger form of this variety. Crown Princess of Prussia is somewhat similar.

\section{KATHERINE TRACY}

Originated by Ferry.

Introduced by Ferry, 1895 .

Donated by Boddington, 1910; Burpee, 1911.

Description in brief - A soft pink, with lighter edges.

Description in detail - Color of stanclard mauve-rose 153 (1), center 153 (4); wings mauve-rose 153 (2). Flower of medium size, open form; standard of medium size, flat, with notched top; wings of medium size, short, partly open. Flowers two, on medium stems. Fragrant. Bloom profuse. A garden variety. Plant of tall. strong, healthy growth. Leaflets broad, pointed; tendrils green; no axillary color shown.

Remarks - One of the most famous American varieties.

\section{PEACH BLOSSOM}

Originated by Eckford.

Introduced by Eckford, 1893 .

Donated by Morse, for evolution studies.

Description in brief - Deep pink, shading to light pink on edges.

Description in detail - Color of stanclard shades from matuve-rose 153 (2) in center near base, to rosy white $8(2-3)$ at edges; wings mauve-rose 153 (1), becoming lighter at edges; the early stage of development of the flower shows a trace of yellow; the general effect is a beautiful pink. Flower medium to large, open form; stindard medium to large, flat, with notched top; wings long and narrow, concealing the keel. Flowers two, on medium stems. Very fragrant. Bloom profuse, continuous. Burns slightly. Plant of melium height. Leaflets narrow, pointed, dark green; tenılrils colored.

Comparison - Lovely is the improved form of this variety.

\section{PRINCESS BEATRICE}

Originated by Muskett.

Introduced by C. C. Hurst \& Son, 1883.

Description in brief - Stanclard light pink, wings light rose-pink.

Comparison - Carmine Rose is similar.

Remarks - Given aw:ird by Royal Horticultural Society in August, 1883.

\section{Salmon Shades}

Originated by lickforil.

\section{HENRY ECKFORD}

Donated by Borlilington, Ratwson, I0I0; Burpee, 19 Ir.

Description in brief - A bestutiful silmon color.

Introduced by Eckford, I906. 
Description in detail - Color of standard shrimp pink 75 (2); wings shrimp pink 75 $(2-3)$. Flower above medium size, open form; standard of medium size, flat, with round top; wings short and broad, partly open. Bloom profuse. Moderately fragrant. Burns very badly. Stems strong, but of medium length. A garden variety. Plant of medium height and strong growth. Leaflets narrow, pointed; pedicels red.

Striped and Flaked (Orange-rose group)

\section{CORONET}

Originated by S. T. Walker.

Introduced by Walker, W. T. Hutchins, I 898.

Donated by Morse, for evolution studies.

Description in brief - Light orange-pink stripe on a white ground.

Description in detail - Standard and wings striped with peach-blossom 127 (standard $3-4$, wings $\mathrm{I}-2$ ) on a rosy white 8 (4) ground. Flower large, open form; standard large, flat, with notched top; wings long and broad, concealing the keel. Flowers on slender stems of medium length. Moderately fragrant. Moderately productive. Plant of medium height and slender growth. Leaflets narrow, pointed. Comparison - Aurora is superior.

Striped and Flaked (Pink-on-primrose group)

\section{ELFRIEDA}

Originated by

Introduced by W. W. Johnson \& Son, 1904. Description in brief - Slightly striped with rose on a primrose ground.

Striped and Flaked (Purple and Blue group)

\section{HESTER}

Originated by Miss Hemus.

Introduced by Miss Hemus, 1908.

Donated by Rawson, I9I0; Burpee, I9II.

Description in brief - A deep blue stripe on white.

Description in detail - Ground color of standard and wings purplish-tinted white, striped with violet-purple $192(\mathrm{I}-2)$. Flower of medium size, open form; standard of medium size, erect, with round top; wings long and broad, partly open. Flowers two to three, on medium stems. Fragrant. Bloom profuse. Growth strong, vigorous.

Comparison - Prince Olaf is superior.

\section{MARBLED BLUE}

Originated by Sutton \& Sons.

Introduced by Sutton, 1906.

Description in brief - White, striped with blue.

Comparison - Similar to Hester.

\section{PRINCE OLAF}

Originated by Dobbie.

Introduced by Dobbie, 1908.

Donated by Dobbie.

Description in brief - White, striped with blue.

Description in detail - Color of standard and wings purplish-tinted white, striped with lobelia-blue 205 (3); wings 205 (I). Flower of medium size or larger; standard of 
medium size, slightly reflexerl at times; wings long and broad, partly open. Flowers 11stally three, on long, strong stems. Moderately fragrant. Bloom profuse, continuous. Pelicels blickish. Suitable for home decoration.

Comparison - Has a trifie more red in the flowers than Hester.

Remarks - The best variety in this color and class.

\section{PURPLE BROWN STRIPE}

Donated by Morse, for evolution studies.

Descriplion in brief $-\Lambda$ white variety, striped with maroon on standard and with violet on wings.

Description in detail - Ground color rosy white $8(4)$; standard striped with dark violet I93 (3-4), wings with bright violet-purple. Flower of mellium size; standard of medium size, flat, with narrow base and notched top; wings long and broad, partly open. Flowers two to three, usually two, on long, strong stems. Fragrant. Bloom moderately profuse, but continuous.

Synonyms - A variety named Black Brown Striped proved to be the same. Light Blue and Purple Striped White is the same variety.

Striped Red and Rose (Crimson-on-white group)

Originated by Morse.

Introduced by Vaughan, I 896.

Donated by Morse, Vaughan, I910; Burpee, I9I I.

Description in brief - A carmine stripe on white.

Description in detail - Standard and wings striped with carmine-red on a very white ground. Flower medium to large, open form; standard medium to large, flat; wings long. Flowers two to three, on long, wiry stems. Very fragrant. Bloom profuse, continuous. Plant of medium height and slender growth. Leaflets narrow, pointed; pedicels red.

Comparison - 1)istinct from Queen of the Isles.

Remarks - The brightest red-striped variety. Name originally proposed was Toreador.

\section{COLUMBIA}

Originated by Hutchins.

Introduced by Hutchins, I 897.

Donated by Morse.

Description in brief - Standard light crimson, wings lavender, striped on white.

Originated by Hutchins.

\section{DAYBREAK}

Donated by Morse, for evolution studies.

Description in brief - White, striped with carmine; wings striped with rose.

Description in detait - Color of standard carmine-purple 156 (2) striped and grained on white, back carmine-purple in center with lighter edges; wings white, with markings of violet-rose $15+$ (I). Flower of medium size, open form; standard of medium size, flat, with notched top and narrow base; wings long and narrow, partly open. Flowers two to three, on long, strong stems. Bloom profuse, continuous. Plant of medium height and slender growth. Leaves narrow, pointed. 


\section{INVINCIBLE SCARLET STRIPED}

Description in brief - Red-striped on a white ground.

\section{INVINCIBLE STRIPED}

Originated by

Introduced by Carter, $\mathbf{1} 880$.

Description in brief - Striped with crimson on a white ground.

Description in detail - In Bulletin I I of this station the following description of this variety appears: "Flowers medium size. Standard slightly convex, notched. Color, white streaked with pink, rather cheap. Bloom profuse."

Remarks - Awarded a First Class Certificate by the Royal Horticultural Society on August 22, r883.

Originated by Eckford.

\section{QUEEN OF THE ISLES}

Donated by Morse, for evolution studies.

Description in brief - White, striped with carmine-purple.

Description in detail - Standard striped with carmine-purple 156 (2-3) on a rosy white 8 (3-4) ground; wings striped with solferino-red 157 (I) on a rosy white ground. Flower of medium size, open form; standard of medium size, reflexed, with notched top and narrow base; wings long and narrow. Flowers two, on short or medium stems of only moderate strength. Bloom moderate. Plant of medium height, slender. Leaflets narrow, pointed; tendrils green.

Comparison - Queen of the Isles has more purple in the stripes of the wings, and less intense red in the stripes of the standard, than is found in America. America is a self, Queen of the Isles is not.

\section{RED AND WHITE STRIPED}

Description in detail - In Bulletin I I of this station the variety is described as follows: "Flowers medium size. Standard convex. Color white strongly streaked with pink. Bloom sparse."

Comparison - This variety was superseded by America.

Synonyms - " Is Scarlet Striped."-Bulletin 127 of this station.

Striped Red and Rose (Pink-on-white group)

\section{BERTIE HAMILTON}

Originated by Walker.

Introduced by Walker, $\mathbf{1} 898$. Description in brief - Lightly striped with dark ox blood on front of standard and wings, and more heavily striped on reverse.

\section{DUCHESS OF YORK}

Originated by Eckford.

Introduced by Eckford, I 894.

Donated by Morse, for evolution studies.

Description in brief - A light pink stripe on white.

Description in d-tail - Standard and wings striped with pale lilac-rose I30 (2) on a lilacy white 7 (I) ground. Flower medium to large, open form; standard medium to large, flat; wings long and narrow, concealing the keel. Flowers borne on medium stems. Very fragrant. Bloom profuse, continuous. Plant of medium height and slender growth. Leaflets narrow, pointed; tendrils colored.

Comparison - Ramona is similar in color but is of hooded form. 


\section{MINNEHAHA}

Originated by Walker.

Introduced by Peter Henderson \& Co., I 898.

Description in brief - Striped with pale pink.

\section{White}

Originated by Henderson.

ALBA MAGNIFICA

Donated by Morse, for evolution studies.

Description in brief - A small, white variety.

Description in detail - Color milk white 11 (2-3). lilower small, open form, with notched standard and narrow base.

Comparison - An improvement on Queen of England, but superseded in its turn by Emily Henderson.

\section{EARLIEST WHITE}

Originated by Gould.

Introduced by Burpee, 1906.

Donated by Boddington, Burpee.

Description in brief - A very early, white varicty.

Description in detail - Color milk white 11 (2-3); wings and standard have no trace of color except in the young bud. Flower of melium size, open form; standard notched; wings long and broad. Substance goorl. Flowers one to three, on short to medium stems. Fragrant. Plant dwarf. Leaflets dark green, narrow, pointed. Seed large, rounıl, black.

Remarks - This variety properly belongs to the winter-flowering type, but is also grown in gardens. Valuable only for very early flowers.

\section{EMILY HENDERSON}

Originated by

Introduced by Henderson, 1893 .

Description in brief - A medium-sized, whate variety.

Descriplion in detail - Flower of medium size, open form; standard with notched top and narrow base, inclined to curve back at the sides. Flowers borne on slender stems of moderate length, appearing to be far apart on the stems. Easily injured by wet weather. Plant slentler, but tall.

Remarks - No longer of any value. For ten years the standard white variety

\section{GRACE MAY}

Originaled by -

Introduced by May, I894.

Description in detail - "A magnificent large flowering white sweet pea. The individual flowers often measure two and one half inches in diameter and waxy white color and highly perfumed." - May's catalogue, $\mathbf{I} 894$.

\section{JOSEPHINE WHITE}

Originated by I'erry.

Introduced by lerry, I902.

Description in brief - A white varicty.

MRS. LANGTRY

Originated by -

Introduced by May, 1894 .

Description in bref - "A charming white." - Introducer's description, 1894.

Description in detail - "Flowers merlium size. Standard flat, notched. Color, pure white, rich. Bloom medium."- Bulletin 111 of this station. 


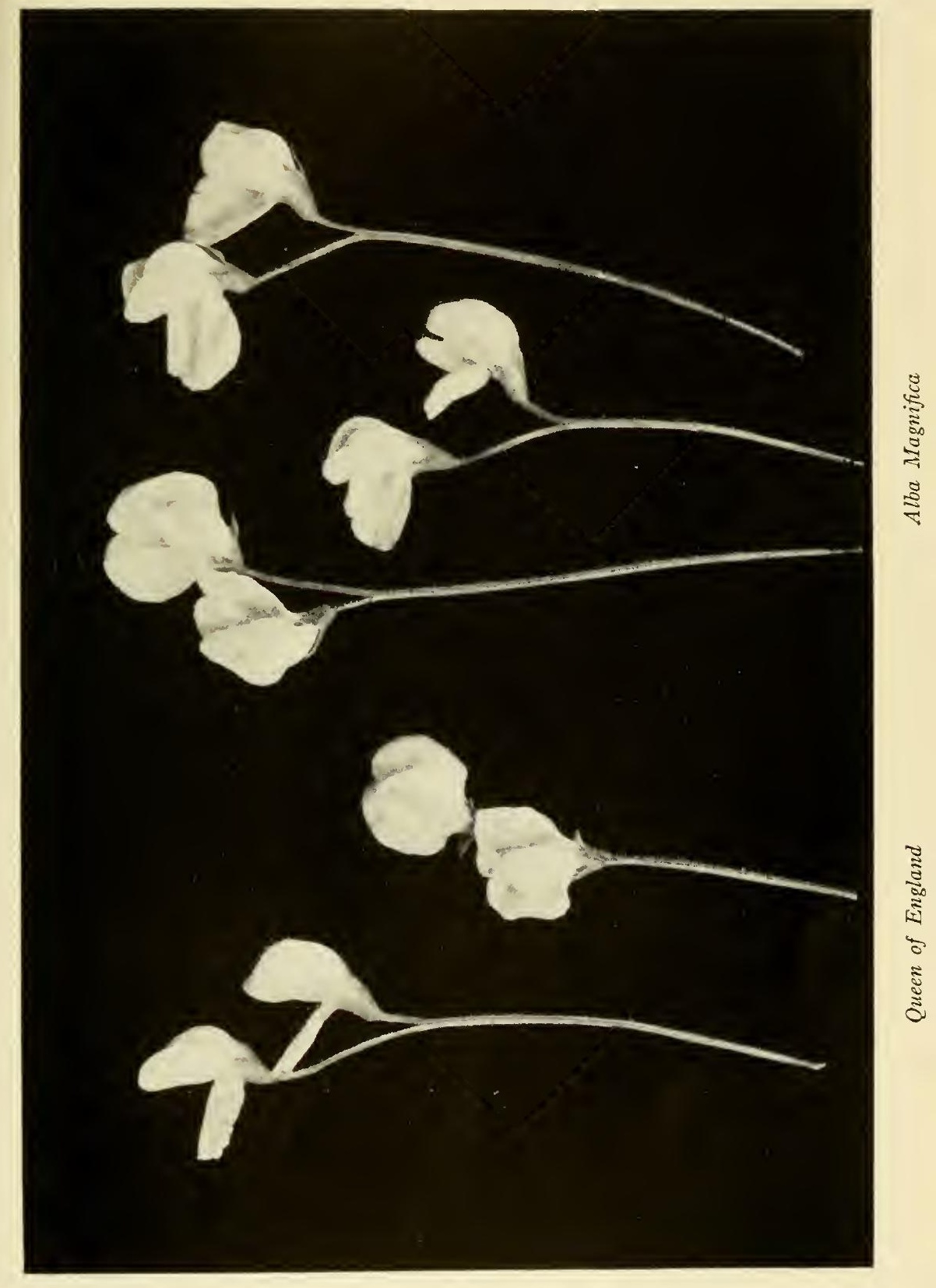




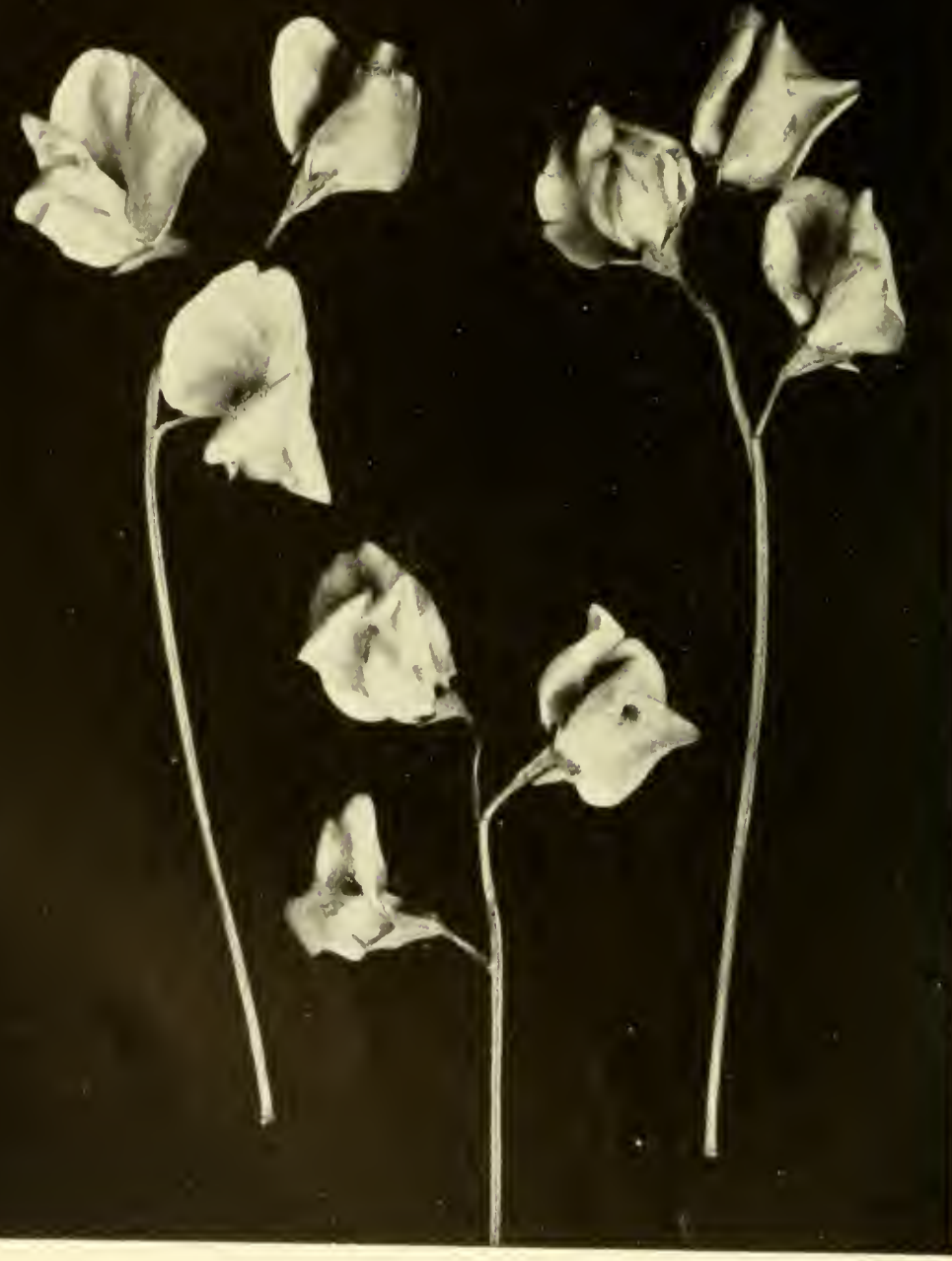




\section{MONT BLANC}

Originated by Ernest Benary(?).

Introduced by Benary, I900.

Donated by Boddington, I910.

Description in brief - An early, pure white variety.

Description in detail - Color of standard and wings creamy white Io (1). Flower of medium size, open form; standard of medium size, flat, notched; wings of medium size, spreading. Plant slender, of dwarf growth. Leaflets narrow, pointed. Seed white.

Comparison - Not so early as Earliest of All, which also has the advantage of black seeds, giving better germination in cold soil early in the spring.

Remarks - Belongs properly to the winter-flowering type, but is grown in gardens for early bloom.

\section{QUEEN OF ENGLAND}

Originated by Eckford.

Introduced by Eckford, I 888 .

Donated by Morse, for evolution studies.

Description in brief - A small, white variety.

Description in detail - Flower small, open form; standard notched at top, often at sicles, and with a narrow base. Flowers two to three, on slender stems of medium length. Plant of tall, vigorous growth.

Comparison - Superseded by Alba Magnifica and Emily Henderson.

Originated by Morse.

Introduced by Morse, I904.

Donated by Boddington, Rawson, i9ro; Burpee, I9I I.

Description in brief - A large, pure white flower, of open form.

Description in detail - Color 2 (I), opens light primrose, changing to pure white.

Flower large, open form; standard large, generally showing a slight notch and a trace of waviness; wings of medium size. Flowers usually three, on long, strong stems. Fragrant. Plant of tall, very strong growth.

\section{SNOWFLAKE}

Originated by S. Fisher.

Introduced by Breck, 1897 .

Description in brief - A pure white.

Remarks - One of the first varieties to receive a first-class certificate from an Américan horticultural society, having received this award from the Massachusetts Horticultural Society in $\mathbf{1} 893$.

\section{WHITE TRIUMPH}

Originated by Miss Hemus.

Introduced by Miss Hemus, 1908 . Description in brief - " A large, expanded white." - Introducer's catalogue. Comparison - A white form of Triumph.

\section{ZERO}

Originated by Biffen.

Introduced by Miss Hemus, I907.

Donated by Miss Hemus, I9Io.

Description in brief - An early, pure white variety. 
Yellow Shades

\section{DEVONSHIRE CREAM}

Originated by Bathurst.

Introduced by G. H. Mackereth, 1908.

Description in brief - A large, primrose variety.

Comparison - Said to be like Shasta in primrose color. Introduced as an improved form of The Honorable Mrs. E. Kenyon.

\section{EARLIEST SUNBEAMS}

Originaled by Morse.

Introduced by Burpee, 1904.

Donated by Boduington.

Description in brief - An carly-flowering, primrose variety.

Description in detail - Color of standaril yellowish white $\mathbf{3}(\mathrm{I}-2)$, back a deeper shade; wings a slightly lighter color. Flower open form; standard notched; wings long and broad. Substance good. Flowers one to three, on medium stems. Moderately fragrant. Bloom early and free. Plant of short height. Leaflets dark green, narrow, pointed. Seed white.

Remarks - Properly belongs to the winter-flowering type. Sometimes planted with Earliest White and Earliest of All for very early bloom.

\section{HAROLD}

Originated by Isaac House \& Sons.

Introduced by House, 1910.

Description in brief - A primrose variety.

Comparison - Said to be a cream-colored Shasta.

\section{INCONSTANCY}

Originated by Ferry.

Introduced by Ferry, 1902.

Donaled by Morse, for evolution studies.

Description in brief - A yellow and white variety.

Description in detail - Color of standard and wings creamy white ro (standard $3^{-4}$, wings $1-2$ ); the standard fades to 10 (I); the general effect is of yellow and white flowers on the same plant, hence the name. Flower of mellium size, open form; standard of medium size, flat, with notched top; wings long and broad, partly open. Flowers on strong stems of medium length. Bloom profuse, continuous. Plant of medium height and slender, healthy growth. Leaflets narrow, pointed; tendrils green. Seed white.

\section{PRIMROSE}

Originated by Eckford.

Introduced by Eckford, I889.

Description in brief - A light primrose self, of medium size and open form.

Comparison - Golden Gleam, Mrs. Eckford, and similar varieties, are larger, finer varicties of this shade. 


\section{Bicolor}

Originated by

-

\section{HOODED VARIETIES}

\section{AMERICAN BELLE}

Introduced by Burpee, 1894.

Description in brief - " Standard bright rose; wings crystal white, with purplish carmine spots." - Introducer's description.

Synonyms - In Bulletin 127 of this station American Belle is said to be Apple Blossom.

\section{Originated by Eckford.}

\section{APPLE BLOSSOM}

Donated by Boddington, I9IO; Burpee, I9II.

Description in brief - Standard rose-pink; wings white, tinged with pink.

Description in detail - Color of standard violet-rose 154 (4) in the center, with lighter edges; wings pale pink I35 (I). Flower of medium size, hooded form; standard of medium size, hooded, with round top; wings long and narrow, concealing the keel. Flowers two to three, on good stems. Very fragrant. Bloom profuse, continuous. Plant of medium growth. Leaflets dark green, narrow, pointed.

Comparison - Has greater contrast between standard and wings than is shown in Royal Rose.

Remarks - Very variable in color.

Originated by Eckford.

\section{COQUETTE}

Description in brief - Standard shaded with lavender on a primrose ground; wings primrose.

\section{CROWN JEWEL}

Originated by Echford.

Introduced by Eckford, 1896.

Description in brief - Tinted and veined with violet-rose on a primrose ground.

\section{DAWN}

Originated by G. Stark \& Son.

Introduced by Stark.

Description in brief - Standard light crimson-magenta; wings white, shaded crimson.

\section{EMILY LYNCH}

Originated by Lynch.

Introduced by Lynch, 1897.

Donated by Morse, for evolution studies.

Description in brief - Standard rose; wings rose on a primrose ground.

Description in detail - Color of standard violet-rose I 54 (4); wings mauve-rose 153 ( 1 ) on a primrose-tinted ground. Flower small to medium, hooded form; standard small to medium, hooded, with notched top and sides; wings short and broad, partly open. Flowers two, on short or medium stems. Very fragrant. Bloom profuse, continuous. Burns slightly in hot sunshine. Plant of medium height and slender growth. Leaflets narrow, pointed; tendrils colored at first, changing to green.

Comparison - Superseded by Jeannie Gordon.

Remarks - One of the first of the Apple Blossom group.

\section{HILDA JEFFREY}

Originated by C. W. Breadmore.

Introduced by Breadmore, 1908.

Description in brief - "Delicate rose shaded cream."-Gardener's World, I908, page 82 .

Comparison - Is said to be an improvement on Jeannie Gordon. 
Originated by Echford.

\section{JEANNIE GORDON}

Donated by Boddington, Burpee.

Description in brief $-\Lambda$ bright rose on a cream ground.

Description in detail - Color of standard deep rose-pink 120 (1-2); wings rosy pink II 8 (I) on a primrosy ground; base of standard often has a trace of primrose color. Flower medium large, hooded; standard medium large, hooded, with round top; wings long and broad, partly open. Flowers two to three, irregularly placed on long, strong stems. Moderate fragrance. Bloom profuse, continuous. Plant of medium height and strong growth. Leatlets nurrow, pointed; tendrils green.

Comparison - Emily Lynch is very similar in color, but is smaller.

Remarks - The best of the old type in this color.

\section{LADY SKELMERSDALE}

Originated by Eckford.

Introduced by Eckford, I 899 .

Description in brief - " Standard bright rosy lilac; wings slightly shaded bright rosy lilac."- Burpee's catalogue.

\section{MRS. E. GILMAN}

Originated by Eckford.

Introduced by Eckford, 1910.

Description in brief - A pale rose bicolor.

\section{ROYAL ROSE}

Originated by Eckford.

Introduced by Eckford, I 896.

Donated by Morse, I910; Burpee, I9I1.

Description in brief - Standard pink; wings rose, with lighter edges.

Description in detail - Color of standard violet-rose 154 (4), back 155 (1-2); wings violet-rose $15+(1-2)$. Flower large, hooded; standard large, hooded, with round top; wings long and broad, partly open. Flowers two to three, on long, strong stems. Very fragrant. Bloom profuse, continuous. Plant of tall, strong growth. Comparison - The waved form of this varicty is Apple Blossom Spencer.

\section{TWEEDY SMITH}

Originated by Breadmore.

Introduced by Breadmore, 1907. Description in brief - "Standard light magenta lilac; wings light cream." - Morse's Fiekl Notes on Sweet Peas.

Blue and Purple Shades (Bright Blue group)

\section{ENID}

Originated by Miss Hemus.

Introduced by Miss Hemus, I 909 .

Donated by Miss Hemus, IgIo.

Description in brief - A deep blue varicty.

Description in detail - Color of standarel and wings aniline blue 202 ( $1-2)$; wings deeper than standard. Flower of medium size, hooled form; stanclard of medium size, slightly hooded, with round top; wings long and narrow, partly open. Flowers two, on medium stems. Very fragrant. Sumproof. Suitable for home decoration. Plant of melium height, slender, healthy. 'lendrils green. Seel round, mottled.

Comparison - The general effect is lighter than Eileen and leeper than Flora Norton. 
Blue and Purple Shades (Purple standard, blue wings)

\section{CAPTAIN OF THE BLUES}

Originated by Eckford.

Introduced by Eckford, I 889.

Donated by Morse, I9I0; Burpee, I9iI.

Description in brief - Standard bright violet-purple, wings lavender-blue.

Description in detail - Color of standard bright violet-purple I90 (3-4); wings lavender-

blue $204(\mathrm{I}-2)$. Flower of medium size, hooded form; standard of medium size, slightly hooded, with round top; wings of medium size, broad, partly open. Flowers three, equidistant on long, strong stems. Very fragrant. Bloom profuse. continuous. Plant tall, of moderately strong growth. Leaflets narrow, pointed, Comparison - Imperial Blue is an inferior form of this. Baden Powell is considered to be the same.

Remarks - Offered in the United States by Farquhar in I891.

\section{COUNTESS CADOGAN}

Originated by Eckford.

Introduced by Eckford, 1899.

Donated by Boddington, I910; Burpee, I9II.

Description in brief - Standard bluish purple, wings blue.

Description in detail - Color of standard bright violet-purple 190 (2), becoming more blue at the base, baek violet-purple I92 (2); wings bluish violet 203 ( 1 ), losing the purple shading, becoming light blue, back 203 (4). Flower large, hooded form; standard large, hooded, with round top; wings long and broad, partly open. Flowers two to three, usually two, on medium stems. Plant of tall, strong growth. Tendrils show some color.

\section{DAVID R. WILLIAMSON}

Originated by Eckford.

Introduced by Eckford, I905.

Donated by Morse, 1910; Burpee, 1911.

Description in brief - Standard bluish purple, wings lavender-blue.

Description in detail - Color of standard bright violet-purple r9o (2), back 192 (2); wings lavender-blue 20.4 (2); keel same as wings. Flower large, hooded form; standard large, slightly hooded, with round top; wings long and broad, partly open. Flowers two to three, usually two, equidistant on long, strong stems. Very fragrant. Bloom profuse. Plant of tall, strong, healthy growth. Leaflets pointed; tendrils green.

\section{DUKE OF WESTMINSTER}

Originated by Eckford.

Introduced by Eckford, I900.

Donated by Boddington, I910; Burpee, 1911.

Description in brief - Standard purple, wings blue.

Description in detail - Color of standard bishop's violet I89 (4); wings aniline blue 202 (2). Flower large, hooded form; standard large, slightly hooded, with round top; wings long and broad; keel same as wings. Flowers two to three, on long, strong stems. Very fragrant. Bloom profuse. A garden or exhibition variety. Plant of tall, strong growth. Leaflets narrow, pointed; some plants possess axiliary color.

Remarks - One of the best of the old varieties. 


\section{IMPERIAL BLUE}

Originated by Eckford.

Donated by Norse, for evolution stuclies.

Description in brief - Stanclard purple, wings light blue.

Description in detail - Color of stanclard rich pansy-violet 192 (1-2), back 191 (4): wings bishop's violet i 89 (4), shaded lavender-blue 204 (I). Flower of medium size, hoodel form; stanclard of medium size, hooded, with notched sides; wings long and narrow. Bloom profuse.

Comparison - Cilptain of the Blues is a large, improved form of this variation.

Synonyms - Madam Carnot is said to be the same variety. Grand Blue is the same.

\section{MADAME CARINOT}

Originated by Laxton.

Introduced by Laxton, 1892 .

Description in brief $-\Lambda$ small, inferior form of Captain of the Blues.

Synonyms - Morse states that Imperial Blue is the same variety.

\section{WAVERLY}

Originated by Eckford.

Introduced by Eckford.

Description in brief - Standard purple, wings blue.

Comparison - Duke of Westminster is similar but larger.

Blue and Purple Shades (Violet and Indigo group)

\section{BRILLIANT BLUE}

Originated by

Introduced by Burpee, 1907.

Description in brief - $\Lambda$ dark navy blue variety.

Description in detail - Color of standard bluish violet 203 (4-5); wings light bluish violet 202 (4), changing to bluish violet 203 (4). Flower large, hooded form; standard large, slightly hooded, with round top; wings medium broad, partly open to spreacling. Flowers two to three, usually three, on strong stems of medium length. Bloom profusc. Plant of tall, strong growth.

Synonyms - Same as Lord Nelson (House, 1907).

Remarks - The best dark blue of the old type.

\section{LORD NELSON}

Originated by House.

Introduced by House, 1907 .

Donated by Borldington, 19 ro.

Description in brief - I lark navy bluc variety.

Description in detail - (See description of Brilliant Bluc.)

Synonyms - This is the name used in Great Britain for Brilliant Blue.

\section{NAVY BLUE}

Originated by James Sproule.

Introduced by Burpee, 1899.

Description in brief - General effect is dark blue; standard lavender-bluc, wings bluish violet.

Description in detail - Color of standard lavender-blue $204(4-5)$; wings bluish violet 203 (4), hecoming slightly more purple. Flower medium to large, hooded form; standard medium large, slightly hooded, sometimes slightly notched at top; wings 
broad and moderately long, partly open. Flowers two to three, equidistant on strong stems of medium length. Moderately fragrant. Plant of tall, strong growth. Leaflets pointed; tendrils green; no axillary color.

\section{Blush}

Originated by

\section{ACME}

Description in brief - A blush-white variety. Comparison - Said to be a blush Dorothy Eckford.

\section{AGNES ECKFORD}

Originated by Eckford.

Introduced by Eckford, I907.

Donated by Morse, I910; Burpee, I9I I.

Description in brief - A very light pink self.

Description in detail - Color of standard and wings mauve-rose I53 (I-2). Flower above medium size, hooded form; standard above medium size, hooded, with round top; wings long and partly open. Flowers three, equidistant on long stems. Very fragrant. Plant of tall, strong growth. Leaflets narrow, pointed; tendrils colored at first, becoming green when fully developed; axillary color in peduncles and leaflets.

Comparison - Larger and better than California.

\section{BLUSHING BEAUTY}

Originated by Eckford.

Donated by Burpee, 19 I0.

Description in brief - Medium size, light pink.

Description in detail - Color of standard and wings mauve-rose I53 (I); standard becomes paler at the edges. Flower of medium size, hooded form; standard of medium size, extremely hooded, without apical notch; wings of medium size but long, partly open. Flowers usually two, on long stems of moderate strength. Moderately productive. Plant of tall, strong growth.

Comparison - California is similar, but is lighter in color. Royal Robe is similar, but darker. Prima Donna is darker, larger, and superior in every respect.

Originated by Lynch.

\section{CALIFORNIA}

Donated by Morse, I9I0.

Description in brief - A small, very light pink variety.

Description in detail - Color of standard pale rosy pink I29 (I-2); wings lilacy white 7 (4). Flower small, hooded form; standard small, much hooded, often curled; wings of medium size, long, partly open. Flowers usually two, on long stems of moderate strength. Moderately productive. Plant of tall, strong growth.

Comparison - Agnes Eckford is much superior. Blushing Beauty is similar, but darker.

\section{COTTAGE MAID}

Originated by

Introduced by Sutton.

Description in brief - Pale blush on white. 


\section{COUNTESS OF ABERDEEN}

Originated by Eckford.

Introduced by Eckford, I 895.

Description in brief $-\Lambda$ pale pink variety.

\section{DELICATA}

Originated by

Introduced by Stark, 1906.

Description in brief - White, tinted pink.

Synonyms - Considered same ats Modesty.

\section{DUCHESS OF SUTHERLAND}

Originated by Eckford.

Introduced by Eckford, I 898.

Description in brief - Silvery white, tinted pink.

Synonyms - Same as Modesty.

\section{EVELYN BREADMORE}

Originated by Breadmore.

Introduced by Breadmore, 1906. Descreption in brief - Shining white, with slight tinge of pink in standard.

\section{LADY ABERDARE}

Originuted by

Introduced by Breadmore, 1904. Description in brief - "Soft light pink self." - Sweet Pea Annual.

\section{MRS. S. T. WALKER}

Originated by Walker.

Introduced by Walker, I 898.

Descripticn in brief - Palc blush-pink, hooded.

\section{MODESTY}

Originated by Mlorse.

Introduced by Burpee, I 898.

Donuted by Burpee, I91 1 .

Description in brief - Silvery white, tinted pink.

\section{SENSATION}

Originated by Morse.

Introduced by Burpee, I 898.

Description in brief - Stanckard very light pink and buff; wings white.

Comparison - A hoorted Alice Eekford.

Carmine and Rose (Carmine group)

Originated by Eckford.

Introduced by Eckford, 1898.

Description in brief $-\Lambda$ bright rose-crimson, changing to purplish crimson.

\section{MRS. DUGDALE}

Originated by Eckfort.

Introduced by Ėckford, I 899.

Donated by Burpece, $191 \mathrm{I}$

Description in lrief - latrge, slightly hooded, (rimson-rose on a primrose ground.

Descriplion in detail - Plower large, hooded; standarel large, slightly hooded; wings large, long and brourl. 
Originated by

Introduced by Bakers, 1909.

Description in brief - A hooded, rosy carmine self.

Carmine and Rose (Rose group)

\section{BRITISH QUEEN}

Originated by Angus.

Introduced by

Description in brief - A double form of Her Majesty.

Remarks - This was shown by Mr. Angus, Norwood Hall, Aberdeen, and received a First Class Certificate from the Royal Caledonian Horticultural Society in $\mathbf{r} 898$.

\section{CYRIL BREADMORE}

Originated by Breadmore.

Introduced by Breadmore, 1906.

Description in brief - A slightly hooderl, rosy carmine variety.

Synonyms - Practically the same as Lord Roseberry.

\section{ESMERALDA}

Originated by

Introduced by Kelway \& Son.

Description in brief - "A distinct shade of rose."- Kelway Manual, I9I I.

\section{HER MAJESTY}

Originated by Eckford.

Introduced by Eckford, I 892.

Description in brief - Large, hooded, rose-crimson self.

\section{MAJESTIC}

Originated by Morse.

Introduced by Burpee, 1901 .

Description in brief - Large, hooded, rose-red on a primrose ground.

\section{ODDITY}

Originated by Morse.

Introduced by Burpee, 1896.

Donated by Morse, for evolution studies.

Description in brief - Deep pink, with deeper edges; wings lighter pink.

Description in detail - Color of standard violet-rose $154(3-4)$; wings violet-rose

I54 (I). Flower of medium size; standard of medium size, reflexed or crumpled, with notehed sides; wings long and narrow, some wings twisted or curled, concealing the keel. Many flowers are double. Flowers two or three, irregularly placed on long stems of medium strength. Bloom profuse, continuous. Burns slightly. Plant of slender growth. Leaflets narrow, pointed; tendrils green. Remarks - Name given because of the form of the flowers; expresses value also.

\section{OVID}

Originated by Eckford.

Introduced by Eckford, 1893.

Donated by Morse, for evolution studies.

Description in brief - Standard purple-rose, wings violet-rose.

Description in detuil - Color of standard purple-rose 150 (1-2); wings violet-rose i 54 (I), back a deeper color; well-matured flowers are very bright. Flower of medium size, hooded form; standard of medium size, hooded, wings long and broad, con- 
cealing the keel. Flowers two, on medium stems. No apparent fragrance. Bloom profuse, continuous. Burns slightly in very hot sunshine. Plant of medium height and slender growth. Leaflets narrow, pointed.

Comparison - Novelty and Miss Hunt are the same color, but are smaller and open form.

Originated by Eckford.

\section{PRINCE OF WALES}

Donated by Morse, 1910; Burpee, I911.

Description in brief - A large, hooded, rose-crimson variety.

Description in detail - Color of standard and wings violet-rose $154(4-5)$. Flower large, hooded form; standard large, slightly hooded; wings long and broad, concealing the keel. Flowers two to three, on long, strong stems. Fragrance none. Bloom profuse, continuous. A garden variety. Plant of tall, stout, vigorous, healthy growth. Color sometimes shown in axils of leaves and tendrils.

Comparison - Her Majesty and Splendour are smaller and less bright.

Remarks - Represents the greatest advance made in the hooded varieties of this color.

Originated by Eckford.

\section{SPLENDOUR}

Donated by Morse, for evolution studies.

Description in brief - $A$ large, hooded, rose-crimson varicty.

Description in detail - Color of standard Tyrian rose 155 (I); wings Tyrian rose I55 (I-2). Hlower large, hooded form; standard large, hooded, with round and looped top; wings long and broad, concealing the keel. Flowers two to three, on long, strong stems. Very fragrant. Bloom profuse, continuous. Sunproof. Plant of medium height and slender growth. Leaflets narrow, pointed, dark green; tendrils colored.

\section{Cerise}

\section{ANNIE B. GILROY}

Originated by Eckford.

Introduced by Eckford, I909.

Description in brief - "A deep cerise." - Sweet Pea Annual.

Comparison - Introduced as an improved Coccinea.

Remarks - No longer catalogued by the introducer.

\section{COCCINEA}

Originated by Eckford.

Introduced by Eckford, $190 \mathrm{I}$.

Donated by Morse, I9I0; Burpec, 19II.

Description in brief - A bright cerise self.

Description in detail - Color of stanclard and wings crimson-red IIt (I). Flower below medium size, hooded; standard of medium size, slightly loorled, with round top; wings long and narrow, concealing the keel. Mloderately fragrant. Bloom profuse, continuous. Flowers two to three, usually two. Burns badly. Plant of medium height and slender growth. Leaflets narrow, pointed, blue-green; tendrils short, colorel. Halnit distinct.

\section{PRINCESS MAUD OF WALES}

Originated by Eckford.

Introduced by Eckford, 1906.

Description in brief - "A pale coccinea." - Sweet Pea Annual.

Remarks - No longer cutalogued by the originator. 


\section{Cream-Pink}

Originated by Tuttle.

\section{CORAL GEM}

Donated by Vaughan, i9io.

Description in brief - A soft, light cream-pink.

Description in detail - Color of standard and wings mauve-rose $153(\mathbf{I}-2)$; center stripe of standard $153(4)$. Flower of medium size; standard of medium size, hooded, with round top; wings long and broad. Very fragrant. Bloom profuse.

\section{COUNTESS OF LATHOM}

Originated by Eckford.

Introduced by Eckford, 1900.

Donated by Morse, I9I0; Burpee, I9I I.

Description in brief - A cream-pink self.

Description in detail - Color of standard mauve-rose I53 (2); wings mauve-rose I5.3 $(\mathrm{I}-2)$; both on a primrose ground. Flower of medium size, hooded form; standard of medium size, hooded, with round top; wings broad, partially spreading. Flowers two to three, borne on long stems of medium strength. Moderately fragrant. A moderately productive variety. Plant of tall, vigorous growth. Tendrils green.

Comparison - Color is between Venus and Honorable F. Bouverie.

\section{GRACIE GREENWOOD}

Originated by Eckford.

Introduced by Eckford, 1902. Description in brief - A slightly hooded flower; cream, shaded delicate pink.

\section{G. W. KERR}

Originated by

Introduced by Bakers, I9ro.

Description in brief - Coral-pink, deeper shade on edge.

\section{HONORABLE F. BOUVERIE}

Originated by Eckford.

Introduced by Eckford, I 899.

Donated by Morse, I9IO.

Description in brief - A deep pink on a primrose ground. The edges are very light pink, the color deepening toward the center.

Description in detail - Color of standard and wings mauve-rose $\mathrm{I}_{53}(\mathbf{I}-\mathbf{3}$ ) on a ereamy white Io (3-4) ground. Flower of medium size, hooded form; standard of medium size, slightly hooded, with round top; wings short and narrow, partly open. Flowers three, equidistant on long stems. Very fragrant. Bloom profuse. Plant of tall, strong growth. Leaflets broad, pointed; tendrils green.

Comparison - Is Lovely on a primrose ground.

Originated by Morse.

Introduced by Burpee, 1903.

Donated by Boddington, Burpee, I9Io.

Description in brief - Bright pink, tinged with buff.

Description in detail - Color of wings and standard mauve-rose I53 (2-3); standard shows traces of yellow, which is more pronounced in the upper flower as well as in the bud. Flower large, hooded form; standard large, hooded, with round top; 
wings long, upright, and pointed. Nlowers two to three, usually three, equidistant on long, strong stems. Morleritely fragrant. Plant of tall, strong growth.

Leaflets broad, pointed; tendrils colored until mature.

Remarks - One of the best-known varieties.

\section{MISS BOSTOCK}

Originated by

Introduced by Miss Hemus, I 907.

Descriplion in brief - Cream-pink.

\section{MRS. CHARLES MASTERS}

Originated by Eckford.

Introduced by Eckford, 1909 .

Description in brief - " Standard rosy silmon, wings cream." - Sweet Pea Annual.

\section{QUEEN OF SPAIN}

Originated by Echford.

Introduced by Eckford, Iyo7.

Danated by Boddington, I9I0; Burpee, I9I:.

Description in brief - "A pearly pink self."- Sweet Pea Annual.

Description in detail - Color of standard and wings mauve-rose 153 ( 1 ). Flower of medium size, hooded form; standard of medium size, hooded, with round top; wings long and broad, spreading. Flowers two to three, on medium stems. Morlerately frigrant. Bloom profuse. A fine garden variety. Plant of distinct character; growth strong and vigorous. Tenclrils profusely colored; color in axils of peduncles, leaves, and leaflets; flower stems aliso tingel brown.

Comparison - On the grounds at this station this varicty is more productive than Countess of Lathom.

\section{VENUS}

Originated by Eckford.

Introduced by Eekford, I 893.

Donated by Burpee, I910, I91 I.

Description in brief - A hooded varicty; flowers salmon-buff, shaded pink.

Description in detail - Color of standard and wings manve-rose I 53 (I-2) on a primrose ground. Flower of medium size, hooded form; standard of medium size, hooded, with round top; wings short, partly open. Flowers two to three, on medium wiry stems. Very fragrant. Plant of tall, slender growth. Tendrils green.

Remarks - As the season advances, the flowers have more pink color.

Crimson and Scarlet (Crimson group)

\section{BOB}

Originated by

Introduced by Jones, 1908 .

Description in brief - " A deep red with wings tinted rose." - Sweet Pea Annual.

\section{BRILLIANT}

Originated by Morse.

Introduced by Burpee, 1897 .

Donated by Burpee.

Descriftion in brief - A slightly hooded, crimson-scarlet variety.

Description in detail - Color of standarl camine-purple 156 (2-3); wings Tyrian rose 155 (i). Flower of medium size, slightly hooded form; standard of medium size, slightly hooded, with round top; wings long and broad, concealing the keel. 
Substance poor. Flowers two to three, usually two, on medium stems. Bloom profuse and contintous. Burns badly. Plant of medium height, with slender haulms, but makes a heavy row.

Comparison - Same color as Ignea in standard, but Brilliant has less contrast in wings.

\section{HARVARD}

Originated by

Introduced by Breck, 1894 .

Synonymns - In Bulletin $\mathbf{1} 27$ of this station this is said to be Ignea.

\section{IGNEA}

Originated by Eckford.

Introduced by Eckford, I 892.

Donated by Morse, for evolution studies.

Description in brief - Crimson-scarlet wings, tinged with purplish crimson.

Description in detail - Color of standard carmine-purple I56 (2); wings solferino-red

I 57 (I). Flower of medium size, slightly hooded form; standard medium hooded, with round top and apical fold; wings long and narrow, concealing the keel. Flowers two, on strong stems of medium length. Flower burns badly, the veins soon blackening or taking on a sickly purple hue. Plant of medium height. Leaflets narrow, pointed.

\section{MARS}

Originated by Eckford.

Introduced by Eckford, I 896.

Description in brief - A hooded, rich crimson self.

\section{MILLIE MASLIN}

Originated by Holmes.

Introduced by Sydenham, 1908.

Donated by Burpee, I9II.

Description in brief - A very dark crimson-red.

Description in detail - Color of standard lilac-purple I60 (3-4), veined darker; wings lilac-purple $160(\mathrm{I}-2)$, often with more purple shading. Flower medium large, hooded form; standard medi1m to large, slightly hooded; wings long and narrow. Flowers two to three, on medium stems. Very fragrant. Bloom moderately profuse. Plant of medium height and slender growth. Leaflets narrow, pointed; tendrils green.

Originated by Eckford.

Introduced by Eckford, I 897 .

Donated by Boddington, 1910.

Description in detail - Color of standard crimson-carmine I59 (4); wings crimsoncarmine 159 (2), back I 59 (4). Flower of medium size, hooded form; standard of medium size, slightly hooded; wings of medium size, concealing the keel. Flowers two to three, on medium stems. Fragrance none. Bloom profuse. Sunproof. Plant of medium height and stout growth. Tendrils colored.

Comparison - This variety was superseded by King Edward VII. Salopian is a deeper, richer color, especially in the wings, than Brilliant or Mars.

Remarks - The original Salopian burned badly under a hot sun. By selection a strain was secured which exhibited little or no burning. The trial at this station was probably with this form. A pure stock. 


\section{SUNPROOF SALOPIAN}

Originated by

Introduced by Burpee, 1900.

Donated by Burpee, I910.

Description in brief - A sunproof strain of Salopian.

Remarks - No difference was noted in the trials at this station. It is probable that the Sunproof Salopian was supplied, at least to all American customers, instead of the Salopian, owing to the fact that the latter was subject to burning under our hot suns.

Crimson and Scarlet (Scarlet group)

\section{KESTON RED}

Originated by

Introduced by Jones, 1908 .

Description in brief - A rich scarlet.

Remarks - Was introduced as an improved Scarlet Gem. Not in the trade at the present time.

Originated by Eckford.

\section{QUEEN ALEXANDRA}

Donated by Bodlington, Rawson, 1910; Burpee, 1911.

Description in brief - A bright, intense, scarlet self.

Description in detail - Color of standard and wings French purple 16r (2). Flower of medium size, hooded form; standard of medium size, slightly hooded, with round top; wings long and broad, concealing the keel. Flowers two to three, on long, strong stems. Plant of medium height and slender growth. Leaflets narrow, pointed.

Dark Shades (Maroon group)

\section{ADMIRAL TOGO}

Originated by Breadmore.

Introduced by Breadmore, 1906.

Description in brief - " Extremely dark violet miroon." - Sweet Pea Annual. Flowers hooded.

\section{BLACKBIRD}

Originated by Sharpe.

Introduced by Bolton, r9o8.

Donated by Rawson, I9Io.

Description in brief - A very dark maroon variety.

Description in detail - Color of standard dark purple 191 (4); wings dark purple 191 (I). Flower medium to large, hooded form; standard medium to large, hooled, with round top; wings long and broad, concealing the keel. Flowers two to three, usually two, on long, strong stems. Bloom profuse, continuous. Sunproof. Plant of tall, strong growth. Leaflets broad, pointed; tendrils green. Synonyms - Midnight (Burpee, I908).

\section{BLUE BIRD}

Originated by -

Introduced by Strong.

Description in brief - "Flowers medium size. Standard hooded. Color, dark purple-red. Bloom medium." - Bulletin I I I of this stition. 
Originated by Dobbie.

\section{HANNAH DALE}

Donated by Dobbie, I9I0.

Description in brief - A deep maroon self.

Description in detail - Color of standard and wings deep carmine-violet I74 (4). Flower large, slightly hooded form; standard above large, slightly hooded, with notched top; wings long and broad, concealing the keel. Flowers two to three, on long, strong stems. Fragrance moderate. Bloom profuse, continuous. Plant of medium height and strong growth. Leaflets narrow, pointed; tendrils green. Remarks - The flowers decrease rapidly in size.

\section{MIDNIGHT}

Originated by Introduced by Burpee, 1908.

Description in brief - Deep maroon and indigo.

\section{NIGGER}

Originated by House.

Introduced by House, 1905.

Description in brief - "Nearly black."- Sweet Pea Annual.

Dark Shades (Maroon and Bronze group)

\section{H. J. R. DIGGES}

Originated by Eckford.

Introduced by Eckford, I908. Description in brief - "A bright claret shaded maroon." - Eckford's catalogue.

\section{JET}

Originated by Hugh Aldersey. Introduced by Sydenham, I909. Description in brief - Standard very dark maroon; wings very dark indigo. Synonyms - Considered the same as Midnight (Burpee, I908).

\section{OTHELLO}

Originated by Eckford.

Introduced by Eckford, $\cdot \mathbf{I} 899$.

Donated by Boddington, I9I0; Burpee, I9II.

Description in brief - A deep maroon self.

Description in detail - Back of standard dull. Flower large, hooded form; standard large, hooded, with round top; wings large, long and broad, concealing the keel. Substance good. Flowers generally three, on long, strong stems. Fragrance little or none. Plant of tall, strong, robust growth. Leaflets narrow, pointed.

\section{SHAHZADA}

Originated by Eckford.

Introduced by Eckford, I 897 .

Donated by Boddington, I9Io.

Description in brief - A very dark maroon and purple variety.

Description in detail - Color of standard dark purple I9I (4); wings violet-purple I92 (2-3). Flower of medium size, hooded; standard slightly hooded, with round top; wings of medium size, long, partly open. Flowers two to three, usually two, on short, weak stems.

Comparison - Has standard of the same color as Othello, but the wings are different. Remarks - Said to be a cross between Stanley and Her Majesty. 
Dark Shades (.Marron and Violet gronp)

\section{DOUBLE DUKE OF CLARENCE}

Originated by

Introduced by Burpee, I 896 .

Donated by Morse, for evolution stulies.

Description in detail - Color of standard deep carmine-violet $174(4-5)$; wings rich pansy-violet I9I (I). Flower of medium size, hoorled form, double; standard of medium size, hooded, sometimes two on lower flower of the spike; wings long and broad. Flowers two to three, on long, strong stems. Plant of till, vigorous growth.

\section{DUDLEY LEES}

Originated by Breadmore.

Introduced by Breadmore, I908.

Description in brief - A slightly hooded, deep maroon variety.

Comparison - Introduced as an improved Black Knight.

\section{DUKE OF CLARENCE}

Originated by Eckford.

Introduced by Eckford, I 893 .

Description in brief - "A rich dark claret."- Hutchins' catalogue.

Comparison - Double Duke of Clarence is the double form of this.

\section{DUKE OF SUTHERLAND}

Originated by Eckford.

Introduced by Eckford, 1898 .

Donated by Boddington, I9IO.

Description in brief - Standard dark violet, wings deep violet-blue.

Description in detail - Color of standard dark violet 192 (2-3); wings violet-purple $192(2-3)$. Flower medium large, hooded form; standard medium large, hooded, with round top; wings long and broad, partly open. Flowers three, on strong stems of medium length. Bloom profuse. Sunproof. Plant of tall, strong growth. Leaflets broad, pointed; tendrils green.

\section{HORACE WRIGHT}

Originated by Eckford.

Introduced by Eckford, 1907 .

Donated by Burpee, I 9 Io.

Description in detail - Color of standard deep purple I85 (t); rvings bright violetpurple I90 (4), back rich pansy-violet I91 (I). Flower large, hooded form; standard large, slightly hooded, with round top; wings long and broal, concealing the keel. Flowers two to three, on merlium stems. Fragrant. Sunproof. Plant of tall, strong growth. leaflets broad, pointed; tendrils colored; color appears in axils.

Comparison - Indigo King has the same colors but is inferior in every respect.

\section{IMPROVED DUDLEY LEES}

Donated by Bide, I912.

Description in brief - A dark maroon and purple varicty.

Description in detail - Color of standard plum-violet 172 (t or darker); wings plumviolet $172(4)$ to deep purple $185(4)$. Flower large, hooled form; standlard large, slightly hooded; wings long and drooping. Flowers two to three, on strong stems of moderate length. Fragrance molerate. Bloom profuse. Plant of medium height and slender growth. Leaflets broitl; tendrils green. 

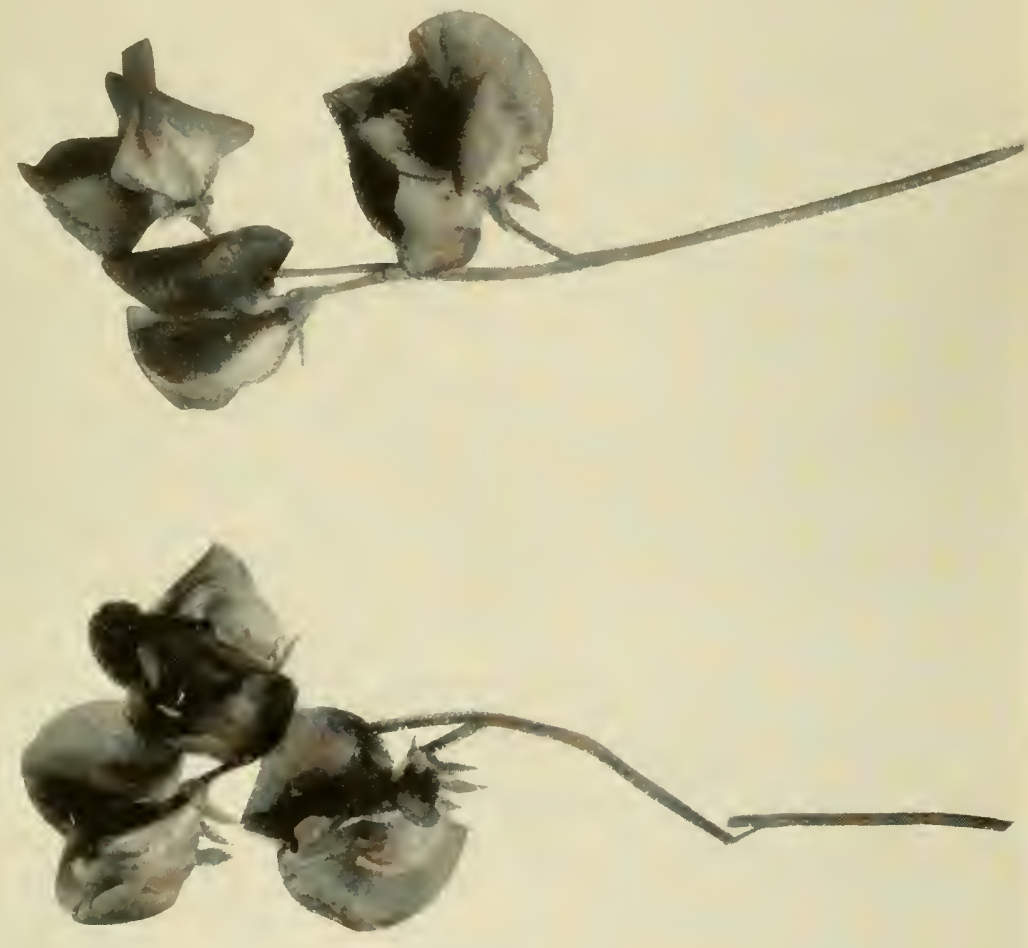

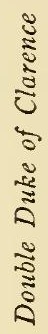

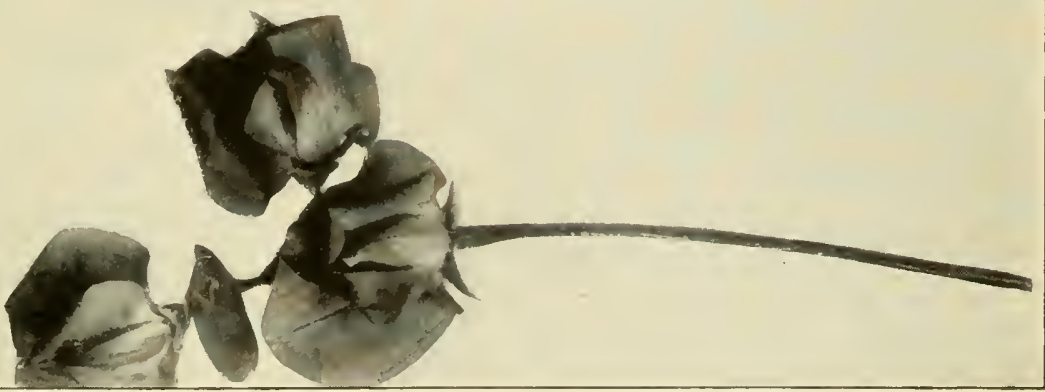




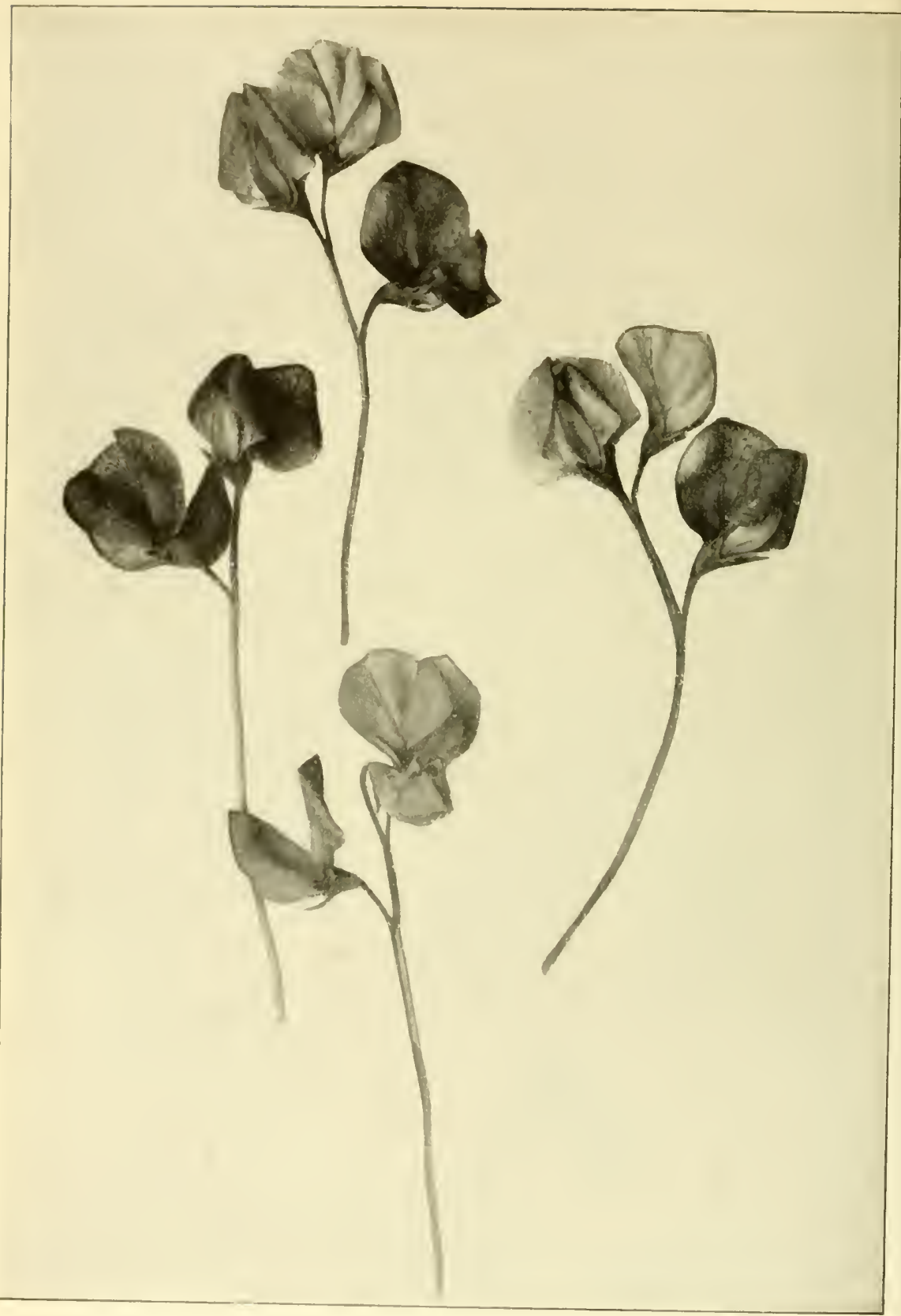

Lord Roseberry 
Comparison - Is larger and darker, and blooms better, than Black Michael. Very similar to Kelway Black. Larger than Black Knight.

Remarks - A very rich, dark-colored flower. Dudley Lees was sent out by Breadmore in 1908.

Originated by Eckford.

\section{INDIGO KING}

Donated by Morse, for evolution studies.

Description in brief - A deep violet-blue.

Description in detail -Color of standard deep carmine-violet 174 (4); wings bright violet-purple 190 (2). Flower under medium size, hooded form; standard under medium size, hooded, notched at side, wings long and narrow. Moderately productive. Plant of medium height.

Comparison - Monarch is somewhat similar in color. Horace Wright is the best variety of these colors.

Synonyms - Autocrat (Henderson, I 888) is the same variety.

\section{KELWAY BLACK}

Originated by

Introduced by Kelway, 1912.

Donated by Kelway, 1912, 1913.

Description in brief - A deep maroon variety.

Description in detail - Color of standard purple-brown $166\left(3^{-4}\right)$, veined with plumviolet; wings plum-violet $172(2-3)$. Flower large, hooded form; standard large, reflexed, with notched top and broad base; wings long and broad. Substance good. Flowers two to three, on medium stems. Very fragrant. Bloom profuse. Plant of medium height and slender growth. Leaflets narrow, pointed; tendrils green.

Comparison - Similar to Black Knight.

\section{MONARCH}

Originated by Eckford.

Introduced by Eckford, I89I.

Donated by Mlorse, for evolution studies.

Description in brief - A deep maroon-violet.

Description in detail - Color of standard plum-violet 172 (4); wings bright violetpurple I9o (4), back rich pansy-violet 19I (I-2). Flower of medium size, hooded form; standard of medium size, slightly hooded; wings long and narrow. Moderately productive. Plant of medium height.

Comparison - Indigo King is smaller and less desirable. Duke of Sutherland is larger and has more blue in the wings.

\section{PURPLE KING}

Originated by Eckford.

Introduced by Eckford, 1908.

Description in brief - A very large, purple flower.

\section{PURPLE PRINCE}

Originated by Eckford.

Introduced by Eckford, 1889.

Donated by Morse, for evolution studies.

Description in detail - Color of standard and wings $190(2-4)$; standard deeper than wings. Flower of medium size, hooded; standard of medium size, hooded. 
Fancy

\section{DORA BREADMORE}

Originated by Breadmore.

Introduced by Breadmore, I906.

Donated by Boddington, I910.

Description in brief $-\Lambda$ slightly hooded primrose self, shaded buff.

Description in detail - Standard and wings fleshy white 9 (3-4). Flower of medium size, hooded form; standard of medium size, slightly hooded, with round top; wings short and broad, partly open. Flowers three, irregularly placed on strong stems of moderate length. Very fragrant. Bloom moderate. Plant of tall, moderately strong growth.

Comparison - Somewhat similar to Lady M. Ormsby Gore, but lighter.

\section{LADY M. ORMSBY GORE}

Originated by Eckford.

Introduced by Eckford, 1901 .

Donated by Boddington, 1910.

Description in brief $-\Lambda$ very light primrose.

Description in detail - Color of standard and wings amber-white 12 (1). Flower of medium size, hooded form; standard of medium size, extremely hooded, with round top; wirgs long and broad, spreading. Flowers two to three, usually three, irregularly placed on long, strong stems. Very fragrant. Bloom profuse. Plant of tall, strong growth. Leaflets pointed; tendrils colorel.

Comparison - Coquette is said to have had more pink color. Queen Victoria has less substance, more primrose color, and a pinkish tint in the standard.

Remarks - On this soil and with the hot sunshine, no pink was noticed.

\section{MARCHIONESS OF CHOLMONDELEY}

Originated by Eckford.

Introduced by Eckford, 1904 .

Donated by Boddington, I910; Burpee, I9II.

Description in brief - Cream, overlaid with pink.

Description in detail - Color of standard pale rosy pink I29 (I); wings very lightly tinted pale rosy pink I29 (I); both on a cream ground. Flower of medium size, hooded form; standard of medium size, hooded, with round top; wings short and broad, spreading. Flowers two, equidistant on strong stems of medium length. Bloom profuse. Plant of tall, strong growth. No color in axils.

Comparison - This variety has lighter wings than Venus, which it resembles in the stanclard.

\section{MRS. FITZGERALD}

Originated by Eckford.

Introduced by Eckford, 1900. Synonyms - This is reported as being the same as the variety Stella Morse (Burpee, $1898)$.

MRS. H. KENDALL BARNES

Originated by

Introduced by Dobbie, 1905.

Description in brief - Standard cream, tinted a very light pink; wings light primrose. Comparison - Differs from Lady M. Ormsby Gore in having pink in the standard. 


\section{STELLA MORSE}

Originated by Morse.

Introduced by Burpee, I 898.

Donated by Boddington, I910; Burpee, I9II.

Description in brief - Cream, tinted pink.

Description in detail-Color of standard and wings amber-white I2 (I), tinted

lilacy white 7 (4); deeper color at edges; gencral effect is creamy yellow; buds very yellow. Flower of medium size, hooded form; standard of medium size, slightly hooded, with round top; wings short and broad, spreading. Flowers three, irregularly placed on long, strong stems. Moderately fragrant. Bloom profuse. Plant of tall, strong growth. Leaflets narrow, pointed; tendrils green.

Comparison - Modesty and Duchess of Sutherland are the same, but on a white ground. Synonyms - Mrs. Fitzgerald is a synonym.

\section{SUE EARL}

Originated by Morse.

Introduced by Burpee, 1903.

Donated by Burpee, I910.

Description in brief - Primrose, with a shading of mauve-rose; wings primrose.

Description in detail - Color of standard amber-white I2 (I-2); wings amber-white

I $2(2-3)$; the standards of the lower blossoms take on a tinge of mauve-rose. Flower of medium size, hooded form; standard of medium size, hooded; wings long and broad.

Remarks - Sent out for trial in 1902. Said to have been a cross between Lottie Eckford and Mrs. Eckford.

\section{Lavender}

Originated by C. Lorenz.

Introduced by Lorenz, 1896.

Synonyms - (See New Countess.)

\section{CELESTIAL}

\section{COUNTESS OF RADNOR}

Originated by Eckford.

Introduced by Eckford, I 890.

Donated by Burpee, I910, I9I I.

Description in brief - A lavender variety.

Description in detail - Color of standard heliotrope 188 (I-2); wings heliotrope 188 (I).

Flower of medium size; standard of medium size; wings medium long and narrow.

Flowers two to three. Very fragrant. Bloom profuse. Suitable for home decoration.

Comparison - Soon after it was sent out, Countess of Radnor had too much red in the standard. New Countess and Celestial were improvements in color.

\section{FLORIST LAVENDER}

Originated by - - - .

Introduced by Bath, I909.

Comparison - Said to be a sport of Navy Blue.

\section{J. T. CRIER}

Originated by Breadmore.

Introduced by Breadmore, 1907.

Description in brief - A lavender self. 


\section{LADY COOPER}

Originated by Breadmore.

Introduced by Breadmore, 1906. Description in brief $-\mathrm{A}$ slightly hoorled, clear lavender self.

\section{LADY GRIZEL HAMILTON}

()riginated by Eckford.

Introduced by Eckford, I 899.

Domated by Borklington, 10 I0; Burpee, 1911.

Description in brief - 1 violet and lilac-mauve variety.

Description in defnil - Color of standlard violet-mauve $195(1-2)$; wings lilac-mauve $196(1-2)$; the back in each being a shade deeper. Flower large; standard large, hoodel; wings long and broad. Flowers two to three, on long, moderately strong stems. Very fragrant. Bloom profuse. Suitable for home decoration or for market. l'lant of moderately vigorous growth.

Comparison - Is deeper in color than Countess of Radnor, but fades to the same sharle.

Remarks - The best of its color in the old type.

\section{LADY NINA BALFOUR}

Originated by Eckford.

Introduced by Eckford, I 897 .

Description in brief - Standard mauve, wings lavender.

\section{MADELINE COLE}

Originated by Stark.

Introduced by Stark, 1910.

Description in brief - A pale lavender self.

\section{MINNIE KEEPERS}

Originated by

Introduced by May, 1895 .

Description in brief - "Flower large. Standard hookled. Color, standard pinkish lilac, wings lilac, Bloom medium,"- Bulletin 111 of this station. Described by May ats a "delieate lavender."

MRS. GEORGE HIGGINSON, JR.

Originated by Morse.

Introduced by Vaughan, 1904 .

Donated by Borklington, Vaugham, 19ro; Burpee, I911.

Description in brief $-\Lambda$ very light lavender variety.

Description in delail - Color of standard and wings Parma violet 200 (1-2). Flower of medium size; standard of medium size, slightly hooded; wings medium long and narrow, hooderl, concealing the keel. Flowers two to three, on long, strong stems. Very fragrant. Bloom profuse. Suitable for home decoration.

Synonyms - True laventer is the same variety.

\section{MRS. ISAAC HOUSE}

Originated by

Introduced by House, 1910.

Description in brief - "Silvery lavender." - Sweet Pea Annual.

\section{NEW COUNTESS}

Originated by

Introduced by Burpee, 1897.

Description in brief - A selected strain of Countess of Radnor with no reddish mauve in the stanclard. 
Synonyms - Same as Celestial.

Remarks - "A selection from a single plant." - Swect Peas Up to Date.

\section{THE FAIRY}

Originated by Introduced by Johnson, 1907.

Description in brief - Opens white, changing to lavender.

\section{TRUE LAVENDER}

Originated by Introduced by Bath, I909.

Description in brief - A light lavender variety.

Synonyms - This is said to be another name for Mrs. George Higginson, jr.

\section{Magenta-Rose}

Originated by Eckford.

\section{EARL CROMER}

Donated by Morse, I9I0; Burpee, I9II.

Description in brief - A deep reddish mauve.

Description in detail - Color of standard and wings vinous-mauve $\mathrm{I} 8+$ (I). Flower large, hooded form; standard large, slightly hooded, with round top; wings of medium size, concealing the keel. Flowers two to three, on medium stems. Very fragrant. Bloom profuse, continuous. Burns slightly. Plant of medium height and strong growth. Leaflets narrow, pointed; some plants show color in the developing tendrils; pedicels red; calyx show; some color.

Remarks - A distinct color.

\section{FASHION}

Originated by Morse.

Introduced by Burpee, I 899.

Description in brief - A medium-sized, hooded, rose-magenta self.

Originated by Eckford.

Introduced by Eckford, I907.

Description in brief - A deep reddish mauve.

\section{LORD KENYON}

Originated by Eckford.

Introduced by Eckford, 1900.

Description in brief - A medium-sized, hooded, magenta-rose variety.

\section{LORD ROSEBERRY}

Originated by Eckford.

Introduced by Eckford, 1902.

Donated by Boddington, I9I0; Burpee, I9II.

Description in brief - A rosy magenta variety.

Description in detail - Color of standard violet-rose I54 (4); wings pure mauve I8I $(3-4)$. Flower medium to large, hooded form; standard medium to large, with round top; wings of medium size, long and broad, concealing the keel. Flowers two to three, on long stems. Bloom profuse, continuous. A garden variety. Plant of medium height, but stout and healthy.

Comparison - Similar to Lord Kenyon, but larger. Ovid has less violet color, and is therefore lighter. American Queen is the open-form varicty of this color.

Remarks - One of the best of its color. 


\section{Marbled}

\section{DAWN}

Originated by Walker.

Introduced by Walker, 1898 .

Description in brief - "An improved Gray Friar. A beautiful pea with many double flowers." - American Florist, I 900.

Comparison - Siicl to be a selection from Princess of Wales, the color being a marbled Princess of Wales on white ground.

\section{EXQUISITE}

Originated by Buth.

Introduced by Bath, IoIo.

Description in brief - Veined with blue on a white ground.

\section{GLADYS FRENCH}

Originated by Unwin.

Introduced by Unwin, I 909.

Donaled by Unwin, Igro; Burpee.

Description in brief - A pale Helen Pierce.

Descripticn in detail - Standard veined, mottled, and marbled with light bluish violet 202 (1) on a purplish-tinted white 6 (2) ground; wings purplish-tinted white 6 (2), veined on back 202 (I). Flower of medium size, open form; standard of medium size, flat, with notched top; wings long and broad, concealing the keel. Flowers two to three on stems. Very fragrant. Bloom profuse, continuous. Sunproof. Plant of medium height, strong, healthy. Leaflets narrow, pointed; tendrils green. Comparison - Differs from Helen Pierce chiefly in the amount of color in the flower.

Originated by Morse.

\section{GRAY FRIAR}

Description in brief $-A$ large, hooded flower, marbled with heliotrope on a white ground. Remurks - The watered grayish effect of the color suggested the name.

\section{PERDITA}

Originated by _-_ _

Introduced by Batli.

Description in brief - Marbled with pink on a white ground.

\section{PINK FRIAR}

Originated by Morse.

Introduced by Burpee, 1899 .

Description in brief - A large, hooded flower, lightly marbled with rose-crimson on a white ground.

\section{SPECKLED BEAUTY}

Originated by Morse.

Introduced by Vaughan, 1904.

Description in brief - A large, hooded flower, lightly marbled with light rose-crimson on al primrose ground.

Comparison - Is Pink Friar on a prinrose grouncl.

Synonyms - Domino (Henderson, 1905) is the same variety.

Remarks - The history of Speckled Beauty and Pink liriar indicates that they cannot be lixed. 


\section{Mauve}

Originated by

\section{ADMIRATION}

Donated by Burpee, I910, I911.

Description in brief - A rosy lavender.

Description in detail - Color of standard heliotrope I 88 (I-3); wings 188 (2). Flower of medium size or larger, hooded form; standard of medium size, hooded, sometimes showing trace of an apical notch; wings long and narrow, concealing the keel. Flowers three, irregularly placed on very long, strong stems. Very fragrant. Bloom profuse, continuous. Plant of medium height and strong growth. Leaflets narrow, pointed; axillary color with the leaflets and sometimes with the leaves; tendrils green.

Remarks - "Coauette $\times$ Emily Eckford."- Morse's Field Notes on Sweet Peas.

\section{ARGOSY \\ Originated by \\ Introduced by House.}

Description in brief - Lavender pink.

\section{DOROTHY TENNANT}

Originated by Eckford.

Introduced by Eckford, I 892.

Donated by Morse, 1910; Burpee, I9II.

Description in brief - Large, hooded; flower rosy mauve, changing to heliotrope.

Description in detail - Color of standard bishop's violet I89 (2), changing to heliotrope I 88 (I); wings heliotrope $\mathbf{I} 88$ (I-2). Flower medium to large, hooded form; standard medium to large, hooded, with round top; wings long and narrow, concealing the keel. Flowers two to three, on long, medium stems. Very fragrant. Bloom profuse, continuous. Sunproof. Plant of tall, strong growth. Leaflets broad, pointed; tendrils green.

Comparison - Newly open flowers of Dorothy Tennant resemble those of Emily Eckford, but the latter shade off toward blue.

\section{EMILY ECKFORD}

Originated by Eckford.

Introduced by Eckford, 1893.

Donated by Boddington, I910; Burpee, I911.

Description in brief - A purple-mauve, changing to light blue.

Description in detail - Color of standard and wings purplish mauve I86 (I-2); wings become more blue as the flower ages. Flower of medium size, hooded form; standard of medium size, hooded slightly, with notched top; wings long and broad, concealing the keel. Flowers two to three, on medium stems. Very fragrant. Bloom profuse, continuous. Sunproof. Plant of tall, strong growth. Leaflets pointed; tendrils green.

Comparison - Dorothy Tennant resembles the recently opened blossoms.

Remarks - A cross between Mrs. Sankey and Splendour. Offered in America by Breck in 1893 .

\section{FASCINATION}

Originated by Eckford.

Introduced by Eckford, I 900.

Description in brief - "Standard magenta mauve; wings deep mauve."- Eckford's catalogue. 


\section{MRS. BIEBERSTEDT}

Originated by

Introduced by Bell \& Bieberstedt, 1908.

Donated by Boddington, 1910; Burpee, I9II.

Description in brief - A deep lavender self.

Description in detail - Color of standard and wings purplish matve 186 (1-2), changing to heliotrope $188(1-3)$. Flower large, hooded form; standard large, slightly hooded, with round top; wings long and broad, partly open. Flowers two to three, usually three, on long stems. Very fragrant. Bloom profuse. Sunproof. Plant of strong, vigorous growth. Leaflets broad; tendrils green.

Remarks - Distinct, and a very desirable variety for the garden.

\section{MRS. TOM FOGG}

Originated by Jones.

Introduced by Jones, I908.

Description in brief - " Mauve tinted pink." - Swect Pea Annual.

\section{MRS. WALTER WRIGHT}

Originated by Eckford.

Introduced by Eckford, 1903.

Donated by Borldington, I9I0; Burpee, I9I I.

Description in brief - Standard heliotrope, wings violet.

Description in detail - Color of standard shades from pale light lilac I87 (2) to heliotrope I 88 (2); wings bishop's violet I 89 (I). Flower large, hooded form; standard large, extremely hooded, with round top; wings long and very broad, partly open. Flowers two to three, on long, strong stems. Moderately fragrant. Bloom profuse, continuous. Sunproof. Plant of tall, strong growth. Leaflets broad, pointerl; ten irils green.

Comparison-Color intermediate between Dorothy Tennant an I Emily Eckford. Mrs. Walter Wright is larger than either.

Originated by Eckford.

\section{ROMOLO PIAZZANI}

Donated by Boddington, I9I0; Burpee, I9I I.

Description in brief - A violet-blue, the wings changing to light lilac.

Description in detail - Color of standard bluish lilac 183 (1); wings pate light lilac 187 (1). Flower of medium size, hooded form; standard of medium size, hooder, with round top; wings long and broad, concealing the keel. Flowers two to three, equidistant on medium stems. Moderately fragrant. Bloom profuse, continuous. Sunproof. Plant of medium height and strong growth. Leaflets pointed; tendrils green.

Comparison - 1.ess blue than Emily Eckfort.

\section{Orange Shades}

Originated by Bolton.

\section{BOLTON'S PINK}

Donated by Boddington.

Description in brief - An orange-pink varicty.

Description in detail - Color bronzy old rose It8 (t); wings dark old rose I f9 (I).

Flower large, hooded form; standard large, hooded, without apical notch; wings long and broid, partly open. Flowers usually three, on long, strong stems. Moderately fragrint. Bloom profuse. Burns badly. Plant of tall, strong growth. 


\section{BUTTONHOLE}

Originated by

Introduced by Miss Hemus, 1908.

Description in brief - A salmon-pink variety.

\section{CHANCELLOR}

Originated by Eckford.

Introduced by Eckford, I 898.

Description in brief - Bright orange-pink.

Comparison - Lady Penzance is said to be practically the same, but is perhaps a little lighter.

\section{LADY MARY CURRIE}

Originated by Eckford.

Introduced by Eckford, 1898.

Donated by Burpee, I9II.

Description in brief - Crimson-tinted orange.

\section{MISS WILMOTT}

Originated by

Introduced by Eckford, 190I.

Donated by Boddington, 1910; Burpee, I9II.

Description in brief - Orange-pink, shaded with rose.

Description in detail - Color of standard violet-old rose I 45 (2), edge purple-rose I 50 (4); wings dark old rose 149 (2) in front and purple-rose I 50 (2) on the back. Flower large, hooded form; standard large, hooded, without apical notch; wings long and broad, partly open. Flowers three, on long, strong stems. Very fragrant. Bloom profuse. Burns badly. Plant of very tall, strong growth.

Comparison - Is less resistant to hot sunshine than Miss Wilmott Improved.

\section{MISS WILMOTT IMPROVED}

Originated by

Introduced by Watkins \& Simpson, I9I0.

Donated by Watkins \& Simpson.

Description in brief - " Orange pink shaded rose."- Sweet Pea Annual.

Comparison - This proved to be a good strain of Miss Wilmott.

\section{MRS. J. MILLER}

Originated by Jones.

Introduced by Jones, 1908.

Description in brief - Salmon-pink self.

\section{ORIENTAL}

Originated by Morse.

Introduced by Burpee, I 898.

Description in brief - Bright orange-pink, veined with a deeper shade.

Picotee Edged (Lavender and Blue group)

\section{BUTTERFLY}

Originated by

Introduced by Sutton, 1878 .

Donated by Morse; for evolution studies.

Description in brief - White, tinted purple and edged with blue.

Description in detail - Color of standard and wings edged lobelia blue 205 (I-2) on a purplish-tinted ground $6(3-4)$. Flower small to medium size, hooded form; 
standard small to medium size, hooked, with notched sirles; wings short and broad. Flowers two to three on stems. Very fragrant. Bloon profuse. Plant of tall, strong, healthy growth. Leaflets narrow, pointed; tendrils green.

Comparison - Butterfly, Maid of Honor, and Lottie Eckford vary in the amount of coloring distributed in the flower.

Remarks - One of the most important varieties ever grown.

Originated by Morse.

Intrcduced by Burpee, r 898.

Donated by Morse, for evolution studies.

Descriplion in brief - Standard light purple, with lighter edges; wings light purple-blue. Description in detail - Color of standard bishop's violet I $89(3-4)$; wings heliotrope I $88(\mathbf{I}-2)$. Flower of merlium size, hooded form; standard of medium size, hooded when side notehes are present, flat, with narrow base; wings long and broad. Flowers two to three, equidistant on stems. Very fragrant. Bloom profuse. Plant of tall, strong growth. Leaflets broad, pointed; tendrils green.

Comparison - Standard not the same color as Splendid Lilac. Described by Morse as practically a hooded form of Splenclid Lilac.

Originaled by Morse.

\section{GOLDEN GATE}

Description in brief - Standard soft pinkish mauve; wings light mauve. Flowers have peculiarly shaped wings, which stand up against the standard.

\section{IVY MILLER}

Originated by Miller.

Introduced by Miller, I 908 .

Donated by Burpee.

Description in brief - A light lilac, edged with blue and violet.

Description in detail - Color of standard and wings pale light lilac 187 (I); standard picotee-edged with aniline blue 202 (3); wings picotee-edged with violet-mauve 195 (1). Flower medium large, hooded form; standard of medium size, hooded, with round top; wings long and broad, concealing the keel. Flowers two to three, equidistant on long, strong stems. Very fragrant. Bloom profuse, continuous. Sunproof. Plant of medium height and strong growth, healthy. Leaflets narrow, pointed; tendrils green.

Comparison - Similar to Lottie Eckford in form and size. Has more color suffused in the flower. Superseded by Phenomenal.

\section{LOTTIE ECKFORD}

Originated by' Eckford.

Introduced by Eckford, I 890.

Donated by Boddington, 19 I0; Burpee, I9II.

Description in brief $-\Lambda$ lilac-white varicty, picotec-edged with blue.

Description in detail - Color of standard and wings lilacy white $7(1-4)$, edged with ageratum blue 201 (3). Nany double flowers. Flower medium to large, hooded form; standard medium to large, hooded, with round top; wings long and broad. concealing the keel. Flowers two to three, on medium stems. Mloderately fragrant. Bloom profuse, continuous. Sunproof. Plant of medium height and fairly strong growth. Leaftets narrow, pointed, dark green; tendrils green.

Comparison - Butterfly is somewhat similar, but has less color when the flower opens and is smaller in size. 


\section{MAID OF HONOR}

Originated by Murse.

Introduced by Burpee, I 897.

Dcnated by Burpee, I910, I9II.

Description in brief - White, edged and shaded with light blue.

Description in detail - Color of standard and wings lilacy white 7 (2-3), edged with ageratum blue $201(2-3)$. Flower of medium size, hooded form; standard of medium size, hooded, with round top and many side notches; wings long and broad, concealing the keel. Flowers two to three, on long, strong stems. Very fragrant.

Bloom profuse, continuous. Sunproof.

Comparison - Lottie Eckford is superior.

Synonyms - Butterfly Improved (Henderson Catalogue, I 898 ) is a synonym.

\section{PHENOMENAL}

Originated by Morse.

Introduced by Henderson, 1905.

Donated by Morse, Vick, I9I0; Burpee, 19г1.

Description in brief - White, shaded and edged with mauve and heliotrope.

Description in detail - Color of standard lilacy white $7(3-4)$, picotee-edged with violet-mauve I95 (I) changing to heliotrope I88 (I); wings edged with Parma violet 200 (I). Flower large, hooded form; standard large, hooded, sometimes inclined to be wavy; wings long and broad, concealing the keel. Flowers two to three, on long, strong stems. Fragrant. Bloom profuse, continuous. Sunproof. Plant of tall, strong growth. Leaflets broad, pointed, dark green.

Remarks - The best of the picotee-edged blue varieties of this form. One of the best doubles.

Picotee Edged (Pink group)

Originated by Morse.

Introduced by Burpee, I903.

Donated by Boddington, r9ro; Burpee, I9I I.

Description in detail - Color of standard purplish-tinted white 6 (I), edged with violetrose $15+$ (I), deeper color on back; wings purplish-tinted white, edge same; general effect is pure white with pink edges; primrose-yellow in the bud. Flower of medium size, hooded form; standard of medium size, slightly hooded, shell-shaped, with round top; wings long and narrow. Flowers three, equidistant on long, strong stems. Very fragrant. Bloom profuse. Plant of tall, strong growth. Leaflets broad, pointed; tendrils green; color appears in axils of leaves and leaflets.

Synonyms - Pink Butterfly is a synonym.

Remarks — Some seed was sent out for advance trial in $\mathbf{1 9 0 2 .}$

\section{NYMPHAEA}

Originated by Morse.

Introduced by Morse, Vaughan, I904.

Donated by Morse, Vaughan, I9Io.

Description in detail - Color of standard amber-white I2 (2); wings I2 (I), changing to pale light lilac $\mathbf{1} 87$ (I) except the top flower, which remains white. Flower of medium size, hooded form; standard of medium size, slightly hooded, with slightl: wavy edges and round top; wings long and broad, upright. Flowers three, equidistant on the stem. Moderately fragrant. Bloom profuse. Plant of tall, strong growth. Leaflets broad, pointed; tendrils green; axillary color in leaves an] leaflets. 
Pink

\section{FLORRIE CRUTCHER}

()riginated by - - D. - .

Introduced by Jones, 1908.

Description in brief - Rose-pink, veined with cleeper pink.

\section{LORD DERBY}

Originated by

Introduced by Nay, 1894 .

Description in detail - "Flowers small. Standard slightly concave, wedge-shaped. Color, standarel pink, wings purple-pink. Bloom medium." - Bulletin I I of this station.

Remarks - Color illustration appears on back cover of May's catalogue for $\mathbf{1} 895$.

\section{LOVELY}

Originated by Eckford.

Introduced by Eckford, I 896.

Donated by Boddington, 1910; Burpee, I9II.

Description in detuil - Color of standard and wings mauve-rose $153(1-3)$ on a white ground; color lighter at edges. Flower of medium size, hooded form; standard of medium size, hooded, with round top; wings short and broad, partly open. Flowers three, equiclistant on long, strong stems. Very fragrant. Bloom profuse, continuous. Sunproof. Plant of tall, strong, healthy growth. Leaflets broad, pointed; tendrils green.

Comparison - The perfected type, of which Peach Blossom, Isa Eckford, and Crown l'rincess of Prussia are inferior examples.

MRS. E. HERBERT

Originated by Jones.

Introduced by Jones, 1908.

Description in brief - Lilac-pink, veined deeper.

\section{MRS. KNIGHTS-SMITH}

Criginated by Eckford.

Introduced by Eckford, 1904 .

Description in brief - A pink self, looded, with wide-spreading wings.

\section{PRIMA DONNA}

Originated by Eckford.

Introduced by Eckford, I 896.

Donated by Boddington, 1910; Burpee, I9I I.

Description in brief - A pure pink self.

Description in detul - Color of standard and wings mauve-rose I53 (I). Flower above mexlitum size, hooded form; standard above medium size, hooded, with round top; wings of medium size, short and broad, varying from partly open to spreading. lilowers two to three, ustually three, on long, strong stems. Very fragrant. Bluom profuse. Plant tall, strong, vigorous, healthy. Leaflets broad; tendrils colored; color shown in axils of poluncles and leaflets.

Comparison - Blushing Beauty is similir, but is lighter in color. Royal Robe is slightly darker and is smaller.

Remarks - The leading pink variety of the olil type.

\section{QUEEN OF PINKS}

Originated by

Introduced by Sutton, Igor.

Synonyms - Siticl to le another name for Prima Donna. 


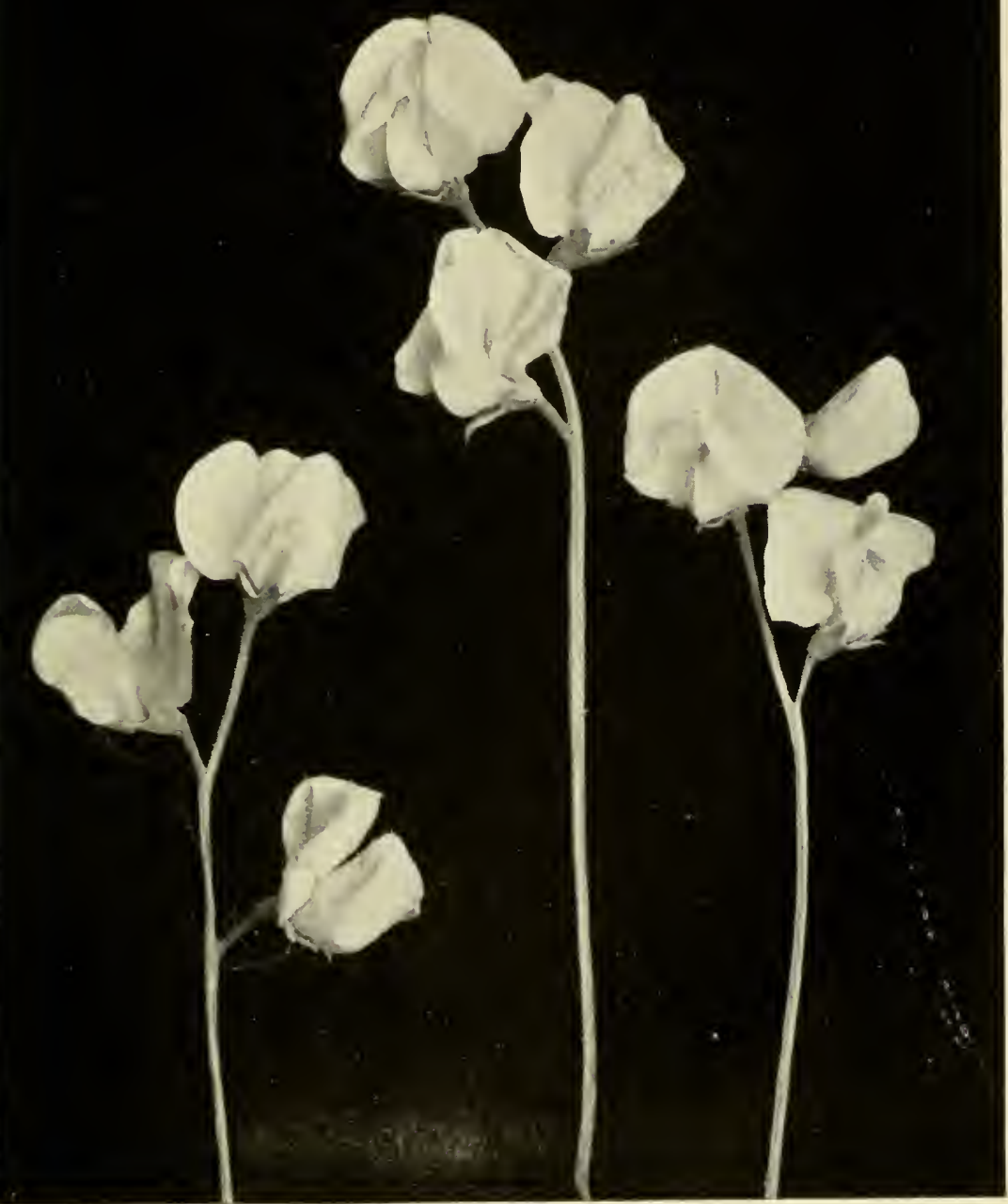

Prima Donna 


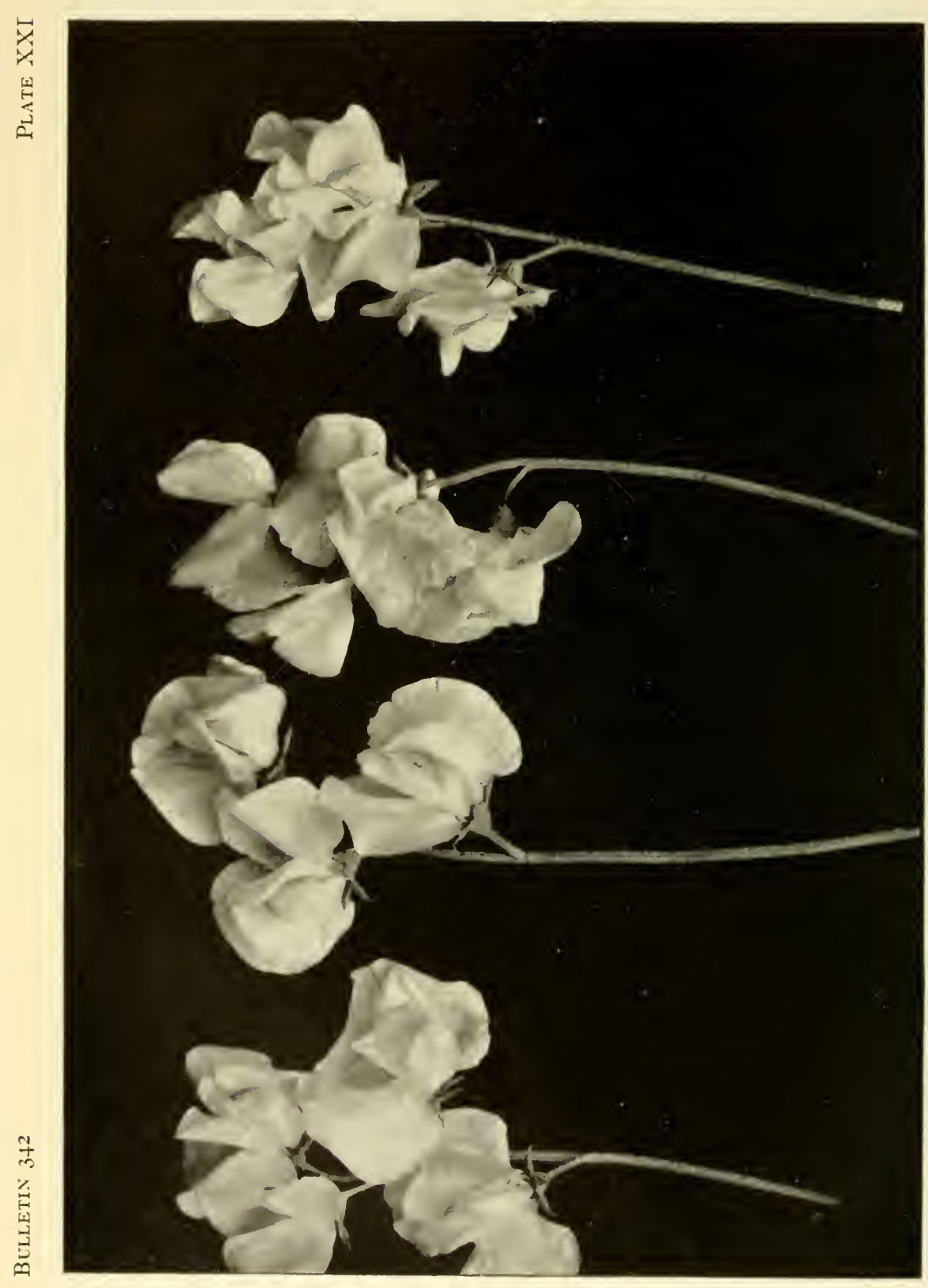


Originated by Stark.

\section{ROSE QUEEN}

Description in brief - A rosy pink self.

Introduced by Stark, 1905.

\section{ROYAL ROBE}

Originated by Eckford.

Introduced by Eckford, I 893 .

Description in brief - A light pink self.

Striped and Flaked (Chocolate stripes)

Originated by Eckford.

Introduced by Eckford, I891.

Donated by Burpee, I9II.

Description in brief - A large, chocolate-striped variety.

Description in detail - Standard and wings striped with purple-brown I66 (I-2) on a purplish-tinted 6 (2) ground. Flower large, hooded form; standard large, hooded, with round top; wings long and broad. Fragrant.

Striped and Flaked (Mauve or blue)

\section{CAPRICE}

Originated by -

Introduced by Henderson, I 888.

Description in brief - "White watered and striped with mauve."- Henderson's catalogue.

\section{DOUGLAS BREADMORE}

Originated by Breadmore.

Introduced by Breadmore, I90ó.

Description in brief - Slightly hooded, flaked with bright purple.

\section{JUANITA}

Originated by Morse.

Introduced by Burpee, 1896.

Donated by Morse, for evolution studies.

Description in brief - White, standard striped with mauve and wings striped with lavender.

Description in detail - Color of standard heliotrope 188 (I) on a lilacy white 7 (I-2) ground; wings suffused with heliotrope. Flower of medium size, hooded form; standard of medium size, hooded, with notched top; wings of medium size, long and broad, partly open. Flowers two to three, usually two, on long, strong stems. Fragrant. Bloom profuse, continuous. Plant of slender growth.

Comparison - Similar to Striped Celestial (Lorenz, 1897).

Remarks - The stock of this was mixed.

\section{NITA}

Originated by Walker.

Introduced by Walker, I 898.

Description in brief - A pale mauve stripe on a white ground.

Comparison - Superseded by Juanita.

\section{PRINCESS OF WALES}

Originated by Eckford.

Introduced by Eckford, I 886.

Description in brief - A hooded flower, striped with mauve and purple on white.

Comparison - Between Senator and Wawona in color. 


\section{STRIPED CELESTIAL}

Originated by Lorenz.

Introduced by Lorenz, 1897 .

Donated by Morse, for evolution studies.

Description in delail - Color of standard heliotrope 188 (I) on a lilacy white $7(\mathbf{I}-2)$ ground; wings suffused with heliotrope. Flower of medium size, hooded form; standarl of medium size, hooded, with notched top; wings of medium size, long and broad, partly open. Flowers two to three, usually two, on long, strong stems. Fragrant. Bloom profuse, continuous. Plant of slender growth.

Comparison - Similar to Juanita.

Remarks - The stock of this was pure.

\section{STRIPED TENNANT}

() riginated by Walker.

Introduced by Walker, 1898 . Description in brief - " A darker form of Nita." - Walker's catalogue.

\section{UNIQUE}

Originated by Stark.

Introduced by Stark, 1906.

Donated by Rawson.

Description in brief - White, striped with light blue.

Descriplion in detail - Color of standard Parma violet 200 (3) on a white ground; wings Parma violet $200(1-2)$ on a white ground. Flower of medium size; standard of medium size, slightly hooded, with round top; wings long and broad, concealing the keel. Flowers two, on long, strong stems. Fragrant. Bloom profuse, continuous. Garden variety. Plant of tall, stout growth.

Comparison - May be known as Flora Norton striped white.

Remarks - A distinct variety.

\section{WAWONA}

Originated by Morse.

Introduced by Burpee, I 898 .

Donated by Morse, for evolution studies.

Description in brief - A lilac stripe on a white ground.

Description in detail - Standard striped with violet-rose $15+$ (4), wings striped with magenta 182 (I), both on a purplish-tinted white $6(4)$ ground. Flower of medium size, hooded form; standard of medium size, hooded, with round top; wings long and broad, concealing the keel. Flowers two to three, on long, strong stems. Bloom profuse, continuous. Plant of medium height and slender growth. Leaflets narrow, pointed; tendrils green.

Comparison - Juanitis is a lighter color.

Striped and Flaked (Red and rose on primrose ground)

\section{EASTERN QUEEN}

Description in brief - "Slightly flaked on cream ground." - Swect Pea Annual.

\section{FLORENCE MOLYNEAUX}

Originated by Dobbie.

Iutroduced by Dobbie, 1905 .

Description in brief - Lightly striped with rose on a primrose ground. 


\section{GOLDEN ROSE}

Originated by Morse.

Introduced by Burpee, 1902.

Donated by Burpee, I9Io.

Description in detail - Color of standard amber-white 12 (3); wings amber-white I2 (I-2), faintly striped with pink, which in hot sunshine quickly disappears. Flower large, hooded form; standard large, slightly hooded, with round top; wings very large, long and broad. Flowers two to three, on medium stems. Moderately fragrant. Bloom profuse, continuous. A garden variety. Plant of tall, strong growth. Leaflets broad; tendrils green.

\section{JESSIE CUTHBERTSON}

Originated by Dobbie.

Introduced by Dobbie, 1903.

Donated by Dobbie, r910; Burpee, I91 r.

Description in brief - Pink stripe on a prinrose ground.

Description in detail - Color Rose Neyron red I 9 (3) stripes on a yellowish white 13

(2) ground. Flower medium to large; standard medium to large, hooded, with round top; wings Iong and broad, concealing the keel. Flowers two to three, on long, strong stems. Moderately fragrant. Bloom profuse, continuous.

Comparison - Sunset is darker.

\section{LOTTIE HUTCHINS}

Originated by Morse.

Introduced by Burpee, I 898. Description in brief - Slightly hooded, light pink stripe on a primrose ground.

\section{SUNSET}

Originated by Morse.

Introduced by Vaughan, 1904.

Donated by Vaughan, 1910.

Description in detail - Color of standard purple-rose $150(\mathrm{I}-2)$ stripes on a purplishtinted $6(\mathrm{I}-2)$ ground; wings $150(2-3)$ on $5(2-3)$ ground. Flower large, hooded form; standard large, slightly hooded, with round top; wings long and broad. Flowers two, on long, strong stems. Moderately fragrant. Bloom profuse, continuous. Plant of medium height and strong growth.

Comparison - Appeared to be a little more heavily striped, and at this station a little larger, than Jessie Cuthbertson.

Remarks - A badly mixed lot, from white to pink and lavender.

Striped and Flaked (Red and rose on white ground)

\section{ANNIE STARK}

Originated by Stark.

Introduced by Stark, 1906.

Description in brief - A medium-sized, hooded flower. Lightly striped with light crimson on a white ground.

Comparison - A heavier stripe than Ramona, but otherwise similar.

\section{AURORA}

Originated by

Introduced by Burpee, I 897 .

Donated by Burpee, 1910, 1911.

Description in brief - White, striped with orange-rose.

Description in detail - Color Rose Neyron red I19 (1) on a sulfury white It (I) ground.

Flower large: standard large, slightly hooded, with round top; wings long and 
broad, concealing the kecl. Flowers two to three, on long, strong stems. Moderately fragrint. Bloom profuse, continuous. A garden or exhibition variety. Plant of medium growth, stout, healthy.

Comparison - Mrs. Joseph Chamberlain does not have the orange tint. Coronet is the true open form of this variety, but becomes pale on the edges.

Remarks - This variety and Dorothy Eckford represent the perfection of the hooded form.

Originated by Dobbic.

\section{BRITANNIA}

Description in brief - A slightly hooded flower, flaked with crimson on a white ground.

Introduced by Dobbie, 1904 .

\section{CAPRICE}

Originated by

Introduced by Johnson, 1906.

Description in brief $-A$ large, slightly hooded flower, delieately striped with carmine on a white ground.

\section{GAIETY}

Originated by Eckford.

Introduced by Eckford, I 893.

Donated by Morse, for evolution sturies.

Description in brief - A red stripe on a rosy white ground.

Description in detail - Color of stripes of standard and wings solferino-red I57 (I-2) on a rosy white ground. Flower of medium size, hooded; standard of medium size, slightly hooded, showing both notched and round apices; wings long and broad. Flowers two to three, usually two, on long, strong stems. Fragrant. Bloom profuse, continuous. Plant of medium height and slender growth. Leaflets narrow, pointed; tendrils green.

\section{LIGHT GAIETY}

Originated by Walker.

Introduced by Walker, 1898 .

Description in brief - A light form of Gaiety.

Comparison - Superseded by Ramona.

\section{MIKADO}

Originated by Eckford.

Introduced by Eckford, 1895.

Description in brief - A large, hooded flower, flaked with bright rose-crimson on a white ground.

\section{MRS. JOSEPH CHAMBERLAIN}

Originated by Eckford.

Introduced by Eckford, I 895 .

Description in brief - White, striped with rose.

Description in detail - Color of stanclard and wings rosy white 8 (1), striped with purple-rose $15^{\circ}(1)$. Flower large; standard large, slightly hooded, with round top; wings long and broad, concealing the keel. Flowers two to three, on long, strong stems. Moderately fragrant. Bloom profuse, eontinuous. Plant of merlium height ancl stout, vigorous, healthy growth.

Comparison - Does not have the orange tint seen in Aurora.

Remarks - Saji to be a eross between Captain of the Blues and Mrs. Sankey. 


\section{OREGONIA}

Originated by Walker.

Introduced by Walker, 1899.

Description in brief - A hooded flower, striped with brownish red on a white ground.

\section{RAMONA}

Originated by Morse.

Introduced by Burpee, I 896.

Donated by Burpee, I9I I.

Description in brief - A light pink stripe on a white ground.

Description in detail - Standard and wings striped with pale lilac-rose 130 (2) on a lilacy white 7 (1) ground.

\section{White}

\section{ALBATROSS}

Originated by Dobbie.

Introduced by Dobbie, 1907.

Description in brief - A pure white, black-seeded variety.

\section{BLANCHE BURPEE}

Originated by Eckford.

Introduced by Eckford, I 894 .

Donated by Burpee, I9II.

Description in brief - A slightly hooded, pure white variety.

Description in detail - Flower medium to large, slightly hooded form; standard medium large; wings notched. Flowers two to three, on short, slender stems. Productive. Wet weather injures flowers. Plant of strong, vigorous growth. Seed white.

\section{DOROTHY ECKFORD}

Originated by Eckford.

Introduced by Eckford, I903.

Donated by Boddington, 1910; Burpee, 1911 .

Description in brief - A large, pure white flower of ideal hooded form.

Description in detail - Color of standard and wings amber-white I 2 (I), becoming pure white. Flower large; standard large, slightly hooded, with round top; wings large, long and broad. Substance good. Flowers three, on long, strong stems. Moderately fragrant. Bloom profuse, continuous. A leading market variety. Plant of tall, strong growth. Leaves dark green. Seed white. Remarks - The ideal hooded type.

\section{FINETTA BATHURST}

Originated by Bathurst.

Introduced by Mackereth, I908.

Description in brief - A large, slightly hooded, white variety.

\section{MRS. SANKEY}

Originated by Eckford.

Introduced by Eckford, I 889 .

Description in brief - A pure white, black-seeded variety.

\section{SADIE BURPEE (black-seeded)}

Originated by Eckford.

Introduced by Eckford, 1899.

Donated by Burpee, I910.

Description in brief - A large, hooded, white variety.

Description in detail - Color of standard purplish-tinted white 6 (3); wings purplishtinted white 6 ( 1 ). Flower large; standard large, much hooded, with round top; 
wings medium broikl, concealing the keel. Flowers three, on long, strong stems. Very fragrant. Plant of tall, erect, wiry growth. Leaves lark green; tendrils colored; color in axiis of leaves and leaflets.

\section{SADIE BURPEE (white-seeded)}

Originated by Eckford.

Introduced by Eckford, I 899 .

Description in brief - A large, hooded, white variety.

Description in detail - Color of standard sage tint 4 (I); wings snow white 2 ( 1 ). Flower large; standard large, much hooded, with round top; wings of medium size, broad, concealing the keel. Very fragrant. Bloom profuse. Stems long and strong, with three flowers. Plant of tall growth. Leaves dark green; tendrils green; no color in axils.

Remarks - There is a form with black seed which shows a pinkish tint in the flowers.

\section{THE BRIDE}

Originated by Lynch.

Introduced by Lynch, I 897

Description in brief - A white-flowered variety of the type of Mrs. Eckford.

Remarks - This variety has white seed and was introduced as a white selection of Mrs. Eckford.

\section{WHITE WONDER}

Originated by Morse.

Introduced by Burpee, 1904.

Donated by Bodtlington, Burpee, 1910; Burpee, 1911.

Description in brief - A large, pure white variety.

Description in detuil - Color of standard and wings creamy white Io (I); flower primrose when it opens, but changes to pure white. Flower large, double; standards often two or three, large and hooded; wings large, long and broad, partly open. Flowers two to four, on long, strong stems; fully one half are double under good culture. Fragrant. Bloom profuse. Plant of tall, strong growth.

Remarks - The best clouble white among the older type of sweet peas.

\section{Yellow Shades}

Originated by Stark.

ALBION

Description in brief - In ivory-white variety.

Introduced by Stark, I906.

\section{CREAM OF BROCKHAMPTON}

Originated by Foster.

Introduced by Foster, 1902.

Description in brief - "A cream self," - Sweet Pea Annual.

\section{FORTY-NINER}

Originated by Sunset Seed and Plant Company. Intreduced by Sunset Seed and Plant Company, isys.

Description in brief - "A soft sulplur-yellow self."- Sweet Pea Review.

Comparison - Henderson placed this variety in the discard list in 1899 , recommending Golden Gleam as superior. 


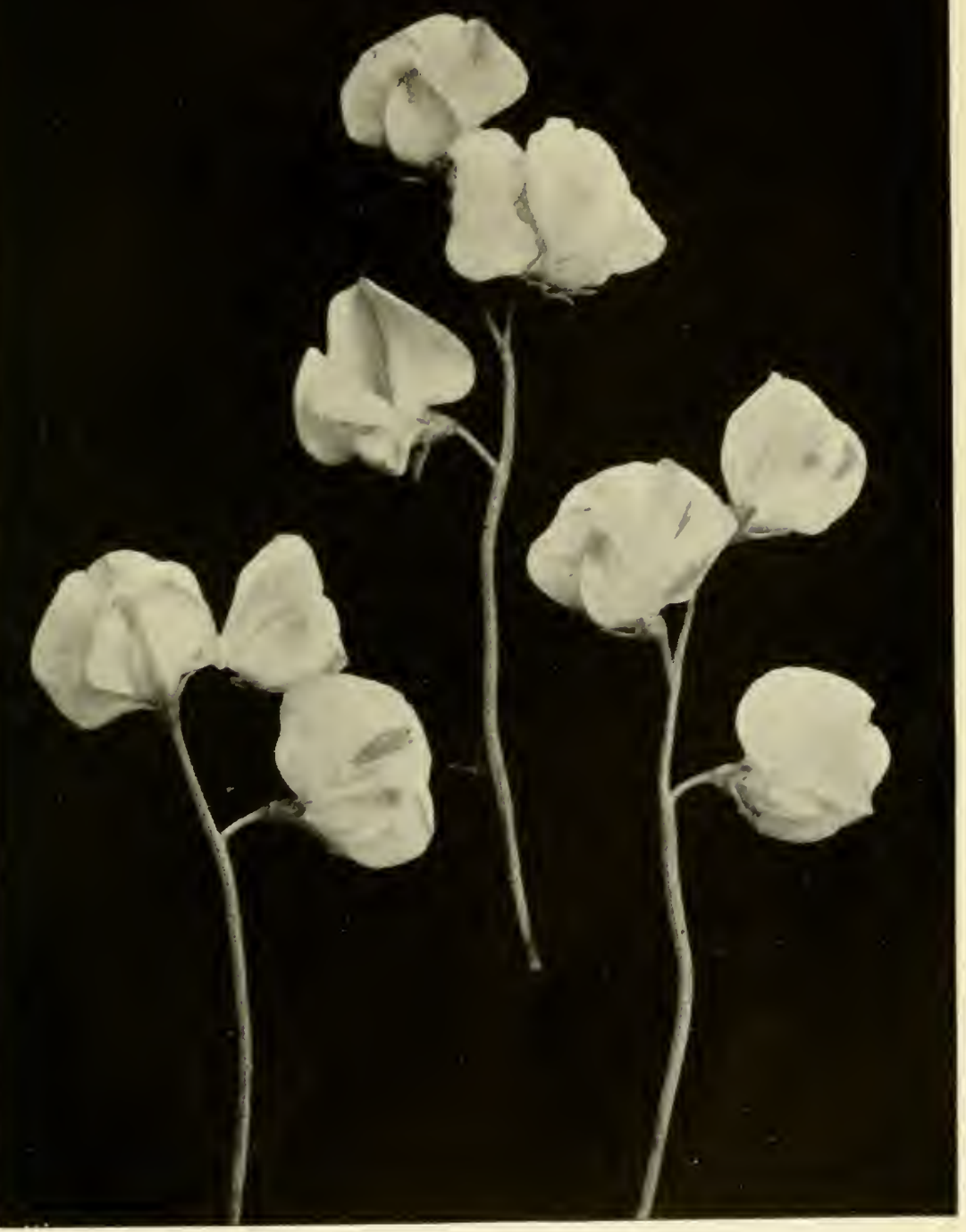

Jumes Grieve 


\section{GOLDEN GLEAM}

Originated by

Introduced by Sunset Seed and Plant Company, I897.

Donated by Morse, for evolution studies.

Description in brief - Described as a yellow form of Blanche Burpee.

Synonyms - Same as Mrs. Eckford.

Originated by Eckford.

\section{JAMES GRIEVE}

Donated by Dobbie, Rawson, I9IO.

Description in brief - A large, yellow variety.

Description in detail - Color of standard sulfury white $1+(2-3)$; wings sulfury white I4 (3-4). Flower large, open form; standard large and erect, with occasional tendency to become slightly hooded and to show trace of the top notch; wings long and broad, spreading laterally, tending to parallel the standard. Flowers two to three, on extra long, strong stems. Very fragrant. Bloom profuse. Plant of tall, strong growth.

\section{MRS. A. MALCOLM}

Originated by Alexander Malcolm.

Introduced by E. W. King, Mackereth, I 009.

Description in brief - A primrose self.

\section{MRS. COLLIER}

Originated by Dobbie.

Introduced by Dobbie, 1907.

Donated by Boddington, Dobbie, I910; Burpee, I9I I.

Description in brief - A rich primrose variety.

Description in detail - Color of standard amber-white 12 (2); wings amber-white 12 (I). Flower large; standard large, slightly hooded, with round top; wings long and broad, spreading. Flowers two to three, on strong stems of medium length. Very fragrant. Bloom profuse. Substance good. Plant of strong, tall growth. Foliage dark green.

Comparison - A primrose Dorothy Eckford.

Synonyms - Dora Cowper (Breadmore, 1907) and Mrs. R. F. Felton (Bolton, 1907).

\section{MRS. ECKFORD}

Originated by Eckford.

Introduced by Eckford, I892.

Donated by Burpee, I9IO, I9II.

Description in brief - A large, semi-hooded, primrose variety.

Description in detail - Color of standard yellowish white I3 (I-2); wings yellowish white I3 (2-3). Flower above medium size; standard medium, slightly hooded, with round top; wings medium, short and broad. Flowers two to three, on very long, strong stems. Moderately fragrant. Bloom profuse. Plant of tall, strong growtl.

Synonyms - Golden Gleam appears to be the same variety.

\section{QUEEN VICTORIA}

Originated by Eckford.

Introduced by Eckford, 1897.

Donated by Boddington, I910; Burpee, I9II.

Description in brief - A light primrose, with a tinge of pink.

Description in detail - Color of standard and wings lilacy white 7 ( $1-2)$; buds with a pinkish tinge, but more color in buds than in those of Mrs. Eckford; the pink color 
disappears as the flower opens. Flower above medium size; standard of medium size, hooled; wings long and broad. Flowers three, on long, strong stems. Very fragrant. Bloom profuse. Plant of tall, strong growth. Tendrils colored at first, becoming green. Seed black.

\section{SAFRANO}

Originated by Gilbert \& Son.

Introduced by Gilbert, 1911.

Discription in bricf - A primrose variety.

\section{THE HONORABLE MRS. E. KENYON}

Originated by Eckford.

Introduced by Eckford, I90I.

Donated by Boddington, 1910; Burpee, I9Ir.

Description in brief - A large, semi-hooded, primrose variety.

Description in detail - Color of standard yellowish white $\mathrm{I}_{3}(3)$; wings yellowish white

I3 (2). Flower large; standard large, slightly hooded, with round top; wings of medium size, broad. Flowers two to three, on long stems of moderate strength. Fragrant. Plant of strong, tall growth. Plant, leaves, and stems have a yellow tinge.

\section{YELLOW HAMMER}

Originated by Breadmore.

Introduced by Breadmore, 1909.

Description in brief - A sulfur-yellow self.

\section{EXTREME HOODED VARIETIES}

\section{Snapdragon}

Originated by Morse.

Introduced by Burpee, 1903.

Donated by Morse, for evolution studies.

Description in detail - Color of standard and wings Rose Neyron red 119 (1) on a rosy white 8 (I) ground. Flower small, snapdragon form. Stems long.

\section{PURPLE SNAPDRAGON}

Originated by

Introduced by Burpee.

Donated by Morse, for evolution studies.

Description in detail - Color of standard shades from bishop's violet 189 (2-3) to bright violet $190(2-4)$; wings lilacy white $7(4)$ to rich pansy-violet 19I $(2-3)$. Flower of medium size, snapdragon form. Stems long.

\section{RED RIDING HOOD}

Originated by Sunset Seed and Plant Company. Introduced by Sunset Seed and Plant

Donated by Morse, for evolution studies. Company, I 897.

Description in brief - A crimson snapdragon variety.

Description in detail - Color of standard Rose Neyron red II9 (4) on a rosy white 8 (I) ground; wings Tyrian rose 155 (1). Flower large, snapdragon form; standard envelops the wings.

Remarks - The first of the snapdragon varieties. 


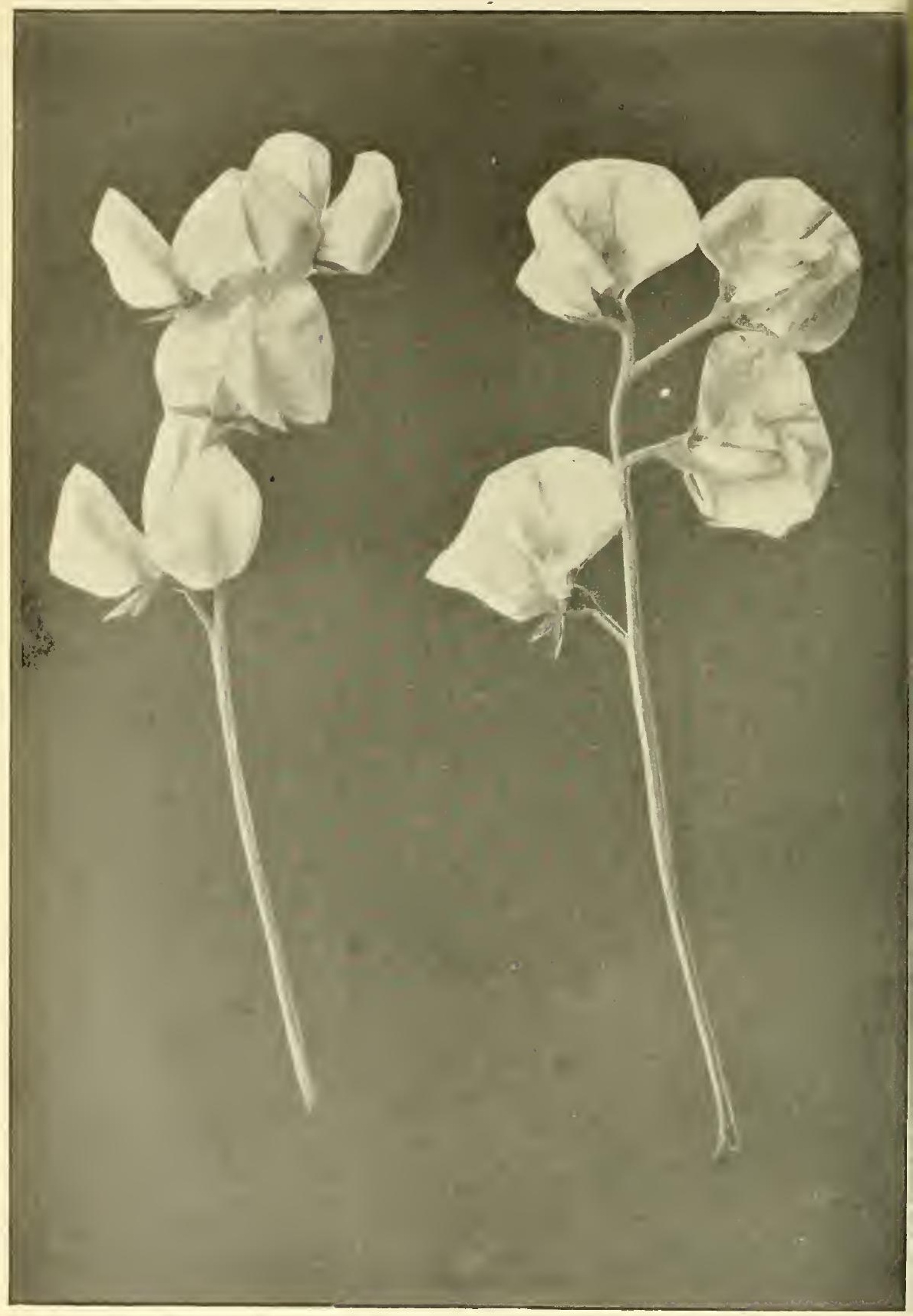

Apple Blossom Spencer 
Classification of Garden Varieties of the Sweet Pea 289

\section{SALVATION LASSIE}

Originated by

Introduced by Burpee, 1902.

Donated by Morse, for evolution studies.

Description in brief - " Light carmine, standards and wings hooded like a bonnet."Burpee's catalogue.

Description in detail - Color of standard violet-rose I54 (I) on a rosy white ground; wings Tyrian rose $\mathbf{I} 55$ (I-2) on a rosy white ground. Flower large, snapdragon form; standard short, folded over wings like a bonnet; wings of usual type.

Comparison - Similar to Red Riding Hood, but with standard more fully developed. Remarks - Valuable as a curiosity.

\section{WHITE SNAPDRAGON}

Originated by

Introduced by Burpee, 1902.

Donated by Morse, for evolution studies.

Description in brief - A white snapdragon variety. 


\section{WAVED VARIETIES}

Bicolor

\section{APPLE BLOSSOM SPENCER}

Originated by

Introduced by Burpee, 1908.

Donated by Burpec, Morse, 1910.

Description in brief - Large to very large, waved, rose bicolor; garden, market, or exhibition variety.

Description in detail - Color of standard lilac-rose 152 (4), wings violet-rose $154(1-2)$, on a faint primrose ground. Standard large, much waved; wings very large, waved. Flowers two to four, on long, very stout stems. Fragrant. Bloom profuse and continuous. Sunproof. Plant of medium height and stout, healthy growth.

Comparison - A misnomer, for it is not like Apple Blossom. It should be called Jcannie Gordon Spencer, as the ground tint is primrose.

Remarks - Introducer's stock pure in I9IO.

\section{ARTHUR UNWIN}

Originated by Unwin.

Introduced by Unwin, 1910.

Donated by Unwin. 19io.

Descriplion in brief - Large, waved, bicolor; carmine-purple and mauve-rose.

Description in detai! - Color of standard carmine-purple 156 ( $1-2)$; wings mauverose $5_{53}$ (I). Standard large, slightly wave1; wings waved, long and broad, concealing the keel. Flowers two to four, on long, strong stems. Fragrant. Sunproof. Plant of medium height and stout, healthy growth.

Comparison - A deeper color than Colleen when viewed on the plants.

\section{BLANCHE FERRY SPENCER}

Donated by Rawson, Vick, 19 ro.

Description in brief - Supposed to be a waved variety of the color of Blanche Ferry.

Remarks - Mostly Apple Blossom Spencer. Contains a few Blanche Ferry, but they are not in Spencer form. Both stocks mixed with White Spencer and other varieties. Nothing has been received at this station since 1910 that could be called Blanche Ferry Spencer.

\section{COLLEEN}

Originated by William Deal.

Introduced by Deal, igro.

Donated by Deal, 1910, I912.

Description in brief - Large, waved, bicolor.

Description in detal - Color of standard carmine-purple 156 (1-2), wings violet-rose I $5+$ (I), on a primrose ground. Flower large, waved form; standard large, waved; wings large, exposing the keel. Flowers three to four, on strong stems. Plant of average growth, strong, healthy. Tendrils colored.

Remarks - An unfixed stock in 1910. Some of the sports approach George Herbert. In 1912 the stock was variable. Some flowers have white wings and carminepurple standards and some are almost selfs; many show mottled flowers, especially as the flowers age.

\section{MRS. ANDREW IRELAND}

Originated by Dobbie.

Introduced by Dobbie, 1909.

Donated by Dobbie, r910.

Description in brief - A large, rose bicolor, waved variety.

Description in deta $l$ - Color of standard lilac-rose $152(3+)$; wings lilac-rose 152 (I).

Standard large: waved; wings waved, long and broad, concealing the keel. Flow- 
ers two to three, on medium stems. Fragrant. Bloom profuse, continuous. Sunproof. Plant of medium height, more slender than most waved varieties, and of healthy growth.

Remarks - Has many double flowers.

Originated by Dobbie.

\section{MRS CUTHBERTSON}

Donated by Burpee, Dobbie, 1912, 1913.

Introduced by Dobbie, 1912.

Description in brief - A large, rose bicolor, waved variety.

Description in detail - Color of standard deep rose-pink I20 (2-3); wings violet rose

I54 (I-4); has a tendency to produce mottled flowers. Flower large to very large, waved form; standard large, waved; wings long and broad. Flowers usually thres, sometimes four, on very long, strong stems. Moderately fragrant. Plant of medium height, healthy, vigorous. Tendrils colored.

Remarks - An improved Apple Blossom. The best variety in this color section.

\section{NEW IMPROVED LUCY HEMUS}

Originated by Miss Hemus.

Introduced by Miss Hemus, 1910.

Donated by Miss Hemus, 1910.

Description in brief-A large, waved, bicolor variety.

Description in detail - Color lilac-rose, standard $15^{2}(2-3)$, wings $15^{2}(1-2)$, on a primrose ground.

Synonyms - Synonymous with Apple Blossom Spencer, the probability of which the introducer admits.

Remarks - A very unfixed stock. The flowers became very mottled during the latter part of August.

\section{TRIUMPH SPENCER}

Originated by Bolton.

Introduced by Bolton, 1909.

Donated by Unwin, 19 цо.

Description in brief - A rose bicolor.

Description in detail - Color of standard purple-rose $15^{\circ}(3-4)$; wings violet-rose I 54 (I).

Comparison - A smaller, inferior, shorter-stemmed Apple Blossom Spencer, also of weaker growth. Distinct from Mrs. Andrew Ireland.

Remarks - Not fixed. Described as a salmon-pink bicolor.

\section{Blue}

Originated by Stark.

Introduced by Stark, 1912.

Donated by Stark, 1912; Boddington, 1913.

Description in brief - A navy blue, waved variety.

Description in detail - Standard dark purple I9I (I); wings violet-purple 192 (2). Flower large, waved form; standard large, waved slightly; wings long and broad, spreading. Flowers three, on long, strong stems. Moderately fragrant. A moderately productive variety. Plants of tall, strong growth. Leaflets broad, pointed.

Remarks - In 1913 this variety broke up, giving one half dark blue stripes. Had it not done this it might be recommended as the best dark blue variety. 


\section{FLORA NORTON SPENCER}

Originated by Morse.

Introduced by Morse, 1909 .

Donated by Morse, 1910; Burpee, 1911; Waldo Rohnert, I912.

Descriplion in brief - A medium-sized, slightly waved, blue variety for the garden.

Description in detail - Color of standard ageratum blue 20I (1); wings 20I (2). Stand-

ard medium large, waved slightly; wings of medium size, long and narrow, conceal-

ing the keel. Flowers two to three, on medium stems. Fragrant. Bloom profuse, continuous. Plant of medium height and strong, healthy growth.

Comparison - Not so pure a blue as Flora Norton. Does not equal Countess Spencer in size.

Remarks - Contained plant of Navy Blue in 19 ro.

\section{LESLIE IMBER}

Originated by Unwin.

Introduced by Unwin, I913.

Donated by Unwin.

Description in brief - Described as a medium blue, with deeper wings.

Description in detail - Color of standard purplish mauve I86 (4); wings light bluish viplet $202(\mathrm{I}-2)$; both become more blue with age. Flower large, waved form; standarl large, waved; wings short and broad, concealing the keel. Flowers two to three, on medium stems. Moderately fragrant. Bloom profuse. Sunproof. Plant of tall, slender growth. Leaflets lark green.

\section{MARGARET MADISON}

Originated by Morse.

Introduced by" Burpee, Morse, I9I 2.

Donated by Burpee, Morse, 1912; Burpee, 1913.

Description in brief - A large, waved, clear pale blue self.

Discription in defail - Color of stanclard bluish violet 199 (I); wings lavender-blue 20+ (I), sometimes flaked darker. Flower large, waved form; standard large, waved; wings long and broad, spreading. Flowers two to three, on medium stems. No fragrance. Moderately productive. Wet weather injures badly. Plant of medium height. Leaflets stout, broad, pointed; tendrils green.

Comparison - Slightly larger than Flora Norton Spencer.

\section{MAY FARQUHAR}

Originated by Unwin.

Introduced by Unwin, I9I I.

Donated by Unwin, 1913.

Description in brief - A deep blue, waved variety.

Description in delail - Color of standard plum-violet $172(3-4)$, overlaid with deep purple; wings bright violet-purple $190(2-3)$, with darker-colored back. Flower large, waved form; standard large, slightly waved; wings short and broad, concealing the keel. Flowers three to four, placed equidistant, close, on strong stems of medium length. No fragrance. Bloom profuse. Sunproof. Plant of tall, strong growth. Leaflets dark green, broad, round; tendrils green.

Remarks - Probably the best dark blue waved variety that is fixed.

\section{SHAWONDASEE}

Originated by Miss Hemus.

Introduced by Miss Hemus, 1910.

Donated by Misis Hemus, 1910.

Description in brief $-\$$ medium-sized, garden variety. 
Description in detail - Color of standard at base light bluish violet 202 ( $\mathrm{I}$ ), the upper part heliotrope I $88(2-3)$; wings 202 (I); the standard loses its pink color, becoming like the wings. Standard of medium size, slightly waved; wings of medium size, long and narrow. Flowers two to three, on fair stems. Fragrant. Bloom profuse. Plant of ordinary growth. Seed mottled.

Comparison - On trial grounds a deeper blue than Zephyr or Flora Norton Spencer. Remarks - Stock pure.

Originated by Sutton.

Introduced by Sutton, 1913.

Donated by Sutton, I9I3.

Description in brief - A waved, deep blue variety.

Description in detail - Color of standard ageratum blue $20 \mathrm{I}(\mathbf{I}-2)$; wings lavenderblue $204(\mathrm{I}-2)$. Flower of medium size, waved form; standard moderately large, slightly waved; wings long and broad, concealing the keel. Flowers two to three, on long, strong stems. No fragrance. Bloom medium. Sunproof. Plant of tall, strong growth. Leaflets broad, round, dark green.

Comparison - Resembles Flora Norton Spencer.

\section{ZEPHYR}

Originated by Biffen.

Introduced by Miss Hemus, Unwin, 1909.

Donated by Miss Hemus, Unwin, 1910.

Description in brief - A medium-sized garden variety.

Description in detail - Color of standard ageratum blue 20I (I); wings 201 (2-3). Standard of medium size, slightly waved; wings of medium size, long and narrow. Flowers three, on fair stems. Fragrant. Bloom profuse. Plant of medium growth. Seed small, yellow-brown, wrinkled.

Comparison - Similar to Flora Norton Spencer.

Remarks - One stock fixed.

\section{Blush}

Originated by Dobbie.

\section{BLUSH QUEEN}

Donated by Dobbie, 1910.

Description in brief - A blush-pink of Unwin form. An excellent garden variety.

Descripticn in detail - Color lilacy white 7 (I), fading to white. Flower medium to large; standard medium to large, Unwin type; wings small, short and narrow, partly open. Flowers three, on long stems. Fragrant. Bloom very profuse. Plant of tall and moderately strong growth. Color in axils of leaflets. Seed black.

Remarks - A fixed stock. One of the best in the blush-pink group.

\section{BOBBY $\mathbf{K}$.}

Originated by Chandler.

Introduced by Unwin, I908.

Donated by Unwin, I9I0.

Description in brief - A large, waved, blush-pink, fine garden variety.

Description in detail - Color of standard and wings lilacy white 7 (I). Standard large, Spencer-waved; wings of medium size, partly open. Flowers three, on long, strong stems. Fragrant. Bloom profuse, continuous. Plant of moderately strong and vigorous growth. Color in axils of leaves. Seed round, black. 
Comparison - Color is lighter than Florence Morse Spenecr.

Remarks - A pure stock.

\section{FLORENCE MORSE SPENCER}

Originated by Morse.

Introduced by Morse, 1908.

Donated by Boddington, Morse.

Description in brief - A large, waved variety, for home, market, or exhibition use.

Delicate blush, with pink margin.

Description in detail - Color of standard pale lilac-rose $\mathrm{I} 30$ (I); wings, front $\mathrm{I} 30$ (2), back $130(3-4)$. Standard large, Spencer-waved; wings large, long and broad.

Flowers three, on long, strong stems. Moderately fragrant. Bloom profuse.

Comparison - Similar to Mrs. Hardcastle Sykes, which has the prior name.

Remarks - One stock pure.

\section{LADY ALTHORP}

Originated by Silas Cole.

Introduced by Cole, 1908 .

Donated by Cole, 1910.

Description in brief - Introducer describes it as blush-white, changing to pure white.

Description in detail - Color of standard lilacy white 7 (3); wings mauve-rose I 53 (I).

Flower of medium size; standard of medium size, Unwin form; wings long and

narrow, concealing the keel. Flowers two to three, on long stems of fair strength.

Plant of tall, strong growth. Color in axils of leaves.

Comparison - Not equal to Mrs. Sankey Spencer, with which it is often grouped.

Remarks - A fixed stock. A deeper pink than any other variety of this group.

\section{LADY EVELYN EYRE}

Originated by Holmes.

Introduced by Sydenham, I9I2.

Donated by Sydenham, 1912.

Description in brief - A very large, waved, blush-pink variety.

Description in detail - Standard cream-white, edged and flushed with bright rose I28 (1); wings lighter than I28 (I). Flower very large, waved form; standard very large, waved, often double; wings large, long and broad, spreading. Substance good. Flowers three, on long, strong stems. Very fragrant. Bloom profuse. Sunproof. Plant of tall, strong growth. Leaflets broad, pointed, dark green.

Comparison - Resembles Florence Morse Spencer in color, but is larger, has stronger stems, and gives a higher percentage of double or triple standards. The plant is stronger than Mrs. Hardcastle Sykes.

Remarks - The finest of the blush-pink varieties in I9I2 and I9I3.

\section{LILA}

Originated by '1'. H. Dipnall.

Introduced by Dipnall, 19 I3.

Donated by Dipnall, 1913.

Description in detail - Color of standard lilacy white 7 (1), veined and flushed with pale lilac; wings snow white 2 ( $\mathrm{I}$ ). Flower medium large, waved form; standard large, very slightly waved; wings short, broad, concealing the keel. Flowers three, on medium stems. Moderate fragrance. Bloom profuse. Sunproof. Plant of tall, slender growth. Leaflets broad, round, dark green.

Remarks - This appears to be distinct. Promising. Stock without color rogues. 


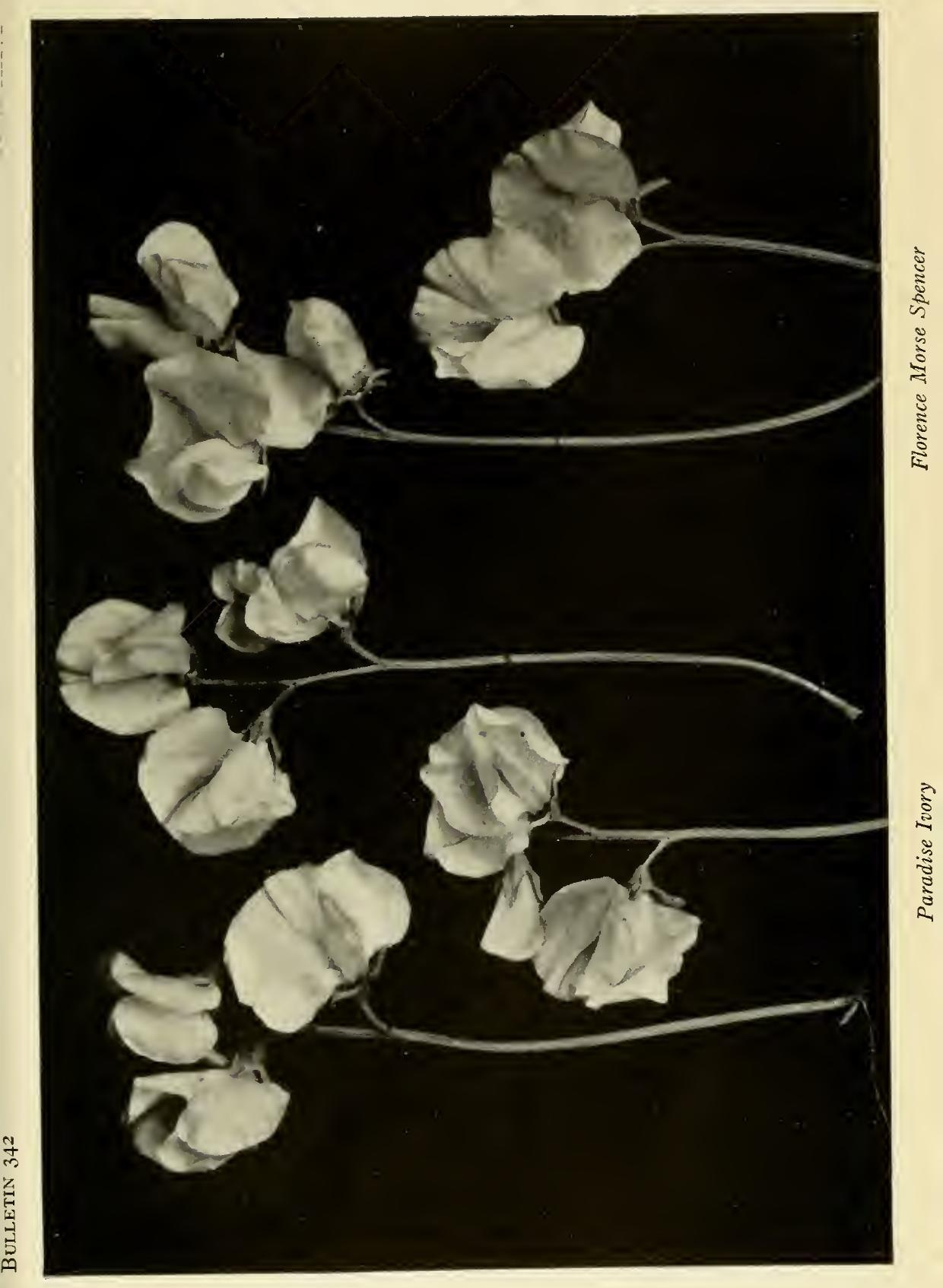




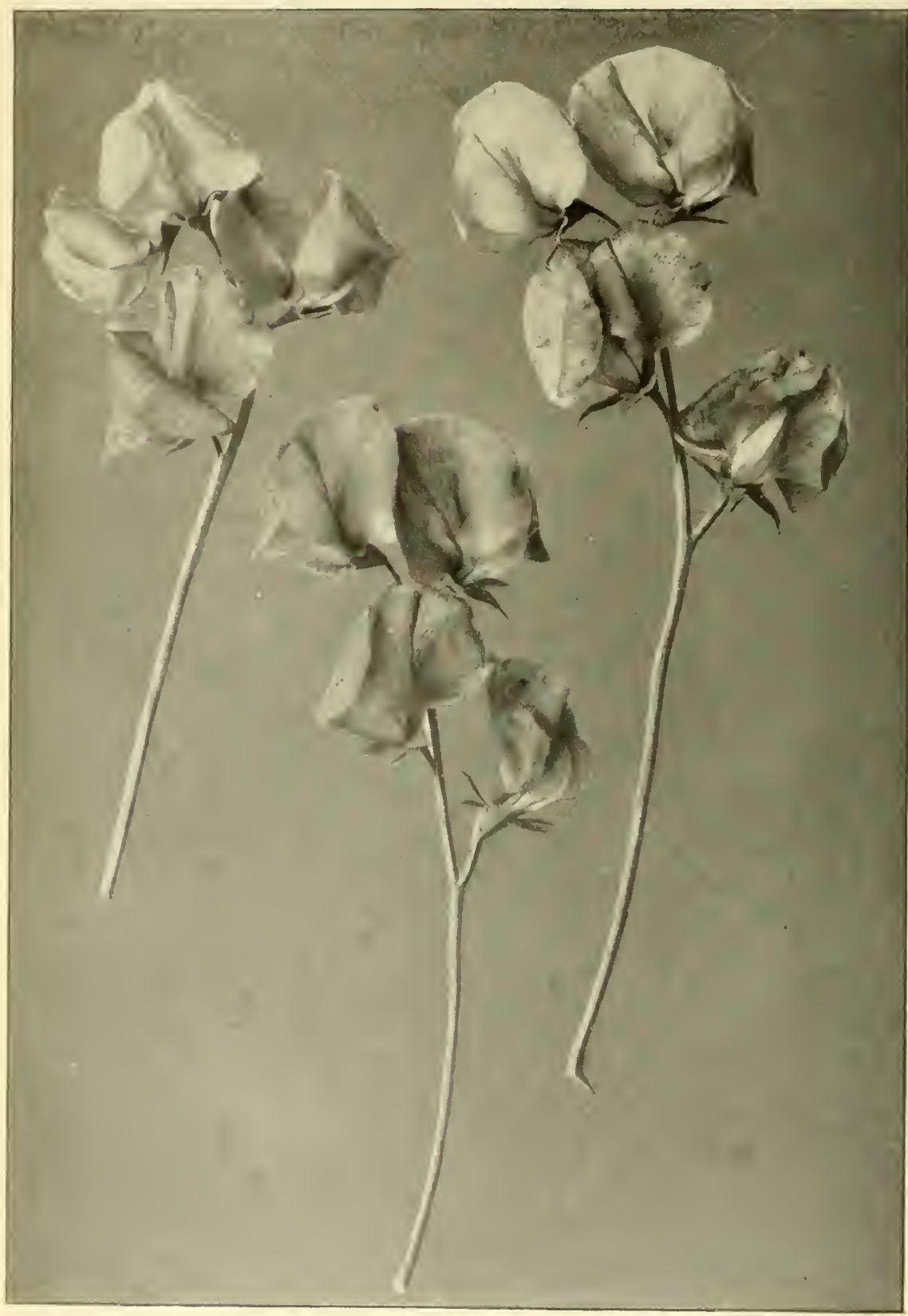


Originated by Stark.

\section{LORNA DOONE}

Donated by Boddington, I9I0.

Comparison - Said to be similar to Florence Morse Spencer and Bobby K.

Remarks - Only one seed grew, and the plant produced white flowers without any trace of color.

\section{MRS. HARDCASTLE SYKES}

Originated by Bolton.

Introduced by Bolton, I 906.

Donated by Boddington, Miss Hemus, I9 Io.

Description in brief - A large, waved, blush-pink variety.

Comparison - Indistinguishable from Florence Morse Spencer, and has the prior name.

Remarks - One stock badly mixed.

\section{PARADISE REGAINED}

Originated by Miss Hemus.

Introduced by Miss Hemus, 1908.

Donated by Miss Hemus, I9I0.

Description in brief - A large-flowered, blush, garden variety.

Description in detail - Color purplish-tinted white $6(2-3)$. Standard large, slightly waved; wings long and broad, concealing the keel. Flowers three, on very long, strong stems. Fragrant. Bloom profuse. Plant of tall, strong growth. Tendrils colored; color in axils of leaves. Seed large, round, black.

Remarks - A pure stock.

Originated by

\section{PRINCESS CATHERINE}

Donated by Vick, I910.

Comparison - The blush-pink selection was not superior to Blush Queen.

Remarks - A very much mixed stock, containing plants with blush-pink, pink, primrose, and white flowers.

Originated by Dobbie.

\section{PRINCESS VICTORIA}

Donated by Dobbie, I9I0; Stark, Morse, Rohnert, 1912.

Description in brief - A large, waved, light pink variety, especially fine for exhibition. Description in detail - Color of standard pale lilac-rose 130 (I-2); wings mauve-rose I53 (I-2). Flower large to very large; standard large to very large, very much waved; wings long and broad, concealing the keel. Flowers three to four, on long, strong stems. Fragrant. Plant of medium height and strong, healthy growth. Tendrils colored.

Comparison - Opening flowers a deeper pink than Florence Morse Spencer, but fading to the same color. In I9Io was superior to Florence Morse Spencer and Mrs. Hardcastle Sykes, and this has since been verified.

Remarks - A pure stock. Some seed-growers have assumed that this is Florence Morse Spencer, but such stocks can be distinguished from the true Princess Victoria.

\section{Carmine}

Originated by Unwin. Donated by Boddington, Rawson, Unwin, and Watkins \& Simpson, I9Io.

Description in brief - A large, waved, carmine-rose variety, for garden or market use.

\section{E. J. CASTLE}

Introduced by Unwin, and Watkins \& Simpson, I907. 
Description in detail - Color of standard lilac-rose 152 (4); wings solferino-red 157 (1).

Standard fairly large, Unwin form; wings long and broad, hooded. Flowers two

to four, on long, strong stems. Fragrance slight or none. Bloom profuse.

Comparison - Similar to Jolnn lngman in color, but not so wavy nor so large. More productive than John Ingmin.

Remarks - Two stocks pure. Unwin's stock was superior to all others.

Originated by Breadmore.

\section{GEORGE HERBERT}

Donated by Morse, Rawson, I910.

Description in brief - A very large, waved, carmine-rose variety.

Comparison - Similar to John Ingman.

Remarks - Both stocks mixel, one with Othello, the other with White Spencer and Frank Dolby, one plant each.

\section{JOHN INGMAN}

Originated by Cole.

Introduced by Sydenham, 1905 .

Donated by Bodrlington, Cole, Dobbie, Morse, Unwin.

Description in brief - A very large, waved, carmine-rose, fine, exhibition variety.

Description in detail - Color of standard lilac-rose I 52 (4); wings solferino-red 157 (I).

Standard large to very large, very waved: wings large, long, waved, concealing the keel. Flowers two to four, on long, strong stems. Fragrance very slight or none. Bloom free, continuous. Growth strong, vigorous, healthy. Seed black. Comparison-Superior to E. J. Castle in form.

Remarks - All stocks were pure as to color. The English stocks were superior in form. The leater of its color.

\section{PARADISE CARMINE}

Originatcd by Miss Hemus.

Introduced by Miss Hemus, 1907 .

Donated by Miss Hemus, r9ı.

Description in brief $-A$ large, waved, carminc-rose variety.

Comparison - Similar to John Ingman.

Remarks - A pure stock.

\section{PHYLLIS UNWIN}

Originated by Unwin.

Introduccả by Unwin, and Watkins \& Simpson, 1906.

Denated by Rawson, and Watkins \& Simpson, 1910.

Description in brief - A large, waved, carmine-rose varicty.

Description in detail - Color of standard lilac-rose 152 (I); wings solferino-red 15 - (I).

Standard large, Unwin form; wings long and broad. Flowers three, on long, strong stems. Bloom free, continuous. Plint of strong, healthy growth. Seed round and bliack.

Comparison - Similar to E. J. Castle, but paler.

Remurks - English stock pure.

Cerise

Originated by Unwin.

\section{CHRISSIE UNWIN}

Donated by Unwin, 1910 .

Description in brief - A medium-sized, cerise variety, suitable for home decoration. 
Description in detail - Color of standard lilac-rose (cerise) 152 (4); wings decp cerise I23 (I-2). Standard of medium size, slightly waved; wings partly open, long and broad. Flowers two to three, on long, strong stems. Fragrance slight or lacking. Bloom profuse. Burns badly in sunshine. Growth below medium height, slender. Tendrils colored and clinging. Seed black.

Comparison - Superior to Coccinea Paradise.

Remarks - A pure stock. The variety lacks size.

\section{COCCINEA PARADISE}

Originated by Miss Hemus.

Introduced by Miss Hemus, I9I0.

Donated by Miss Hemus, I910.

Description in brief - A cerise variety.

Description in detail - Color of standard Rose Neyron red I I9 (3-4); wings I 19 (I). Synonyms - Appears to be Coccinea.

Remarks - Badly mixed with Red Paradise.

Cream, Buff, and Ivory

Originated by Cole.

Introduced by Cole, igro.

Donated by Cole, igro.

Description in brief - A large, waved, primrose variety.

Description in detail - Color of standard yellowish white I3 (2-3); wings I3 (I). Standard large, waved; wings long, very broad, concealing the keel. Substance poor. Flowers two to three, on strong stems of fair length. Moderately fragrant. Fairly productive. Plant of tall, strong, healthy growth. Seed white. Comparison - Not equal to Primrose Spencer or Clara Curtis, which it is said to resemble.

Remarks - A mixed stock in 1910.

\section{CLARA CURTIS}

Originated by Bolton.

Introduced by Bolton, Sharpe, 1908.

Donated by Dobbie, Unwin, I9I0.

Description in brief - A large, waved, primrose variety.

Description in detail - Color of standard yellowish white $\mathrm{I3}(2-3)$; wings 13 (I).

Flower large to very large; standard large, Spencer-waved; wings large, waved.

Flowers two to four, well arranged on long, strong stems. Moderately fragrant.

Bloom profuse. Plant of tall, vigorous growth. Seed white.

Comparison - Similar to Primrose Spencer (Burpee, 1908), but all flowers truly waved. Remarks - Both stocks pure.

\section{DOBBIE'S CREAM}

Originated by Dobbie.

Introduced by Dobbie, I9I2.

Donated by Dobbie, 1912, I913.

Description in detail - Color of standard and wings creamy white Io (I-2). Flower large, waved form; standard large, sometimes double or triple; opens rich yellow, becoming lighter. Flowers usually three, on long, strong stems. Productive. Sunproof. Plant of tall, stout growth. Leaflets broad, round, dark green. 


\section{DOUBLE PRIMROSE BEAUTY}

Originated by Stark.

Introduced by Stark, 1912.

Donated by Stark, 1912.

Description in brief - Similar to Primrose Beauty in every respect except that it produces a few more double flowers.

\section{ELAINE}

Originated by Miss Hemus.

Introduced by Miss Hemus, I910.

Donated by Miss Hemus, I9Io.

Description in brief - $\Lambda$ medium-sized, ivory variety of waved form, useful for garden purposes.

Description in detail - Color of standard fleshy white $9(2-3)$; wings fleshy white $9(3-4)$. Flower of medium size; standard of medium size, waved slightly; wings of medium size, short and broad, partly open, hooded. Flowers two to four, usually three, on long, strong stems. Fragrant. Bloom profuse. Plant of tall, strong growtli. Some color in axils of leaves. . Seed black.

Comparison - Resembles Paradise Ivory.

Remarks - Does not fulfill the originator's description.

\section{GIANT CREAM WAVED}

Originated by Deal.

Introduced by Deal, I9I.

Donated by Deal, 1912.

Description in brief - A large, waved, cream variety.

Description in detail - Flower large, waved form; standard large, waved, sometimes double; wings long and broad. Flowers usually three, sometimes four, on long, strong stems. Productive.

Comparison - Not exceptional in size, being equal to Dobbie's Cream in this respect.

\section{ISOBEL MALCOLM}

Originated by Malcolm.

Introduced by Dobbie, I9II.

Donated by Dobbie, I912.

Description in brief - Large, waved, primrose self.

Descripticn in detail - Color of standard and wings yellowish white 13 (1-3). Flower large, waved form; standard large, much waved; wings large, long and broad, spreading. Flowers three to four, usually three, on long, strong stems. Moderately fragrant. Plant of tall, strong, healthy growth. Leaflets broad, pointed, with axillary color; tendrils green.

Comparison - The general effect is paler than Clara Curtis. An excellent variety.

\section{LADY KNOX}

Originated by Dobbie.

Introduced by Dobbie, 1912.

Donated by Dobbie, 1912, 1913.

Description in brief - Large, waved, flushed with pink on a cream ground.

Description in detail - Color of standard fleshy white 9 (4), edges flushed with pale rosy pink I29 (I), lrightest on the back; wings fleshy white 9 (I), with more delicate edge of pink. Flower large, waved form; standard large, much waved; wings long and broad, spreading. Flowers on long, strong stems; many doubles. Very fragrant. Very productive. Plant of tall, healthy growth. Tendrils green. 


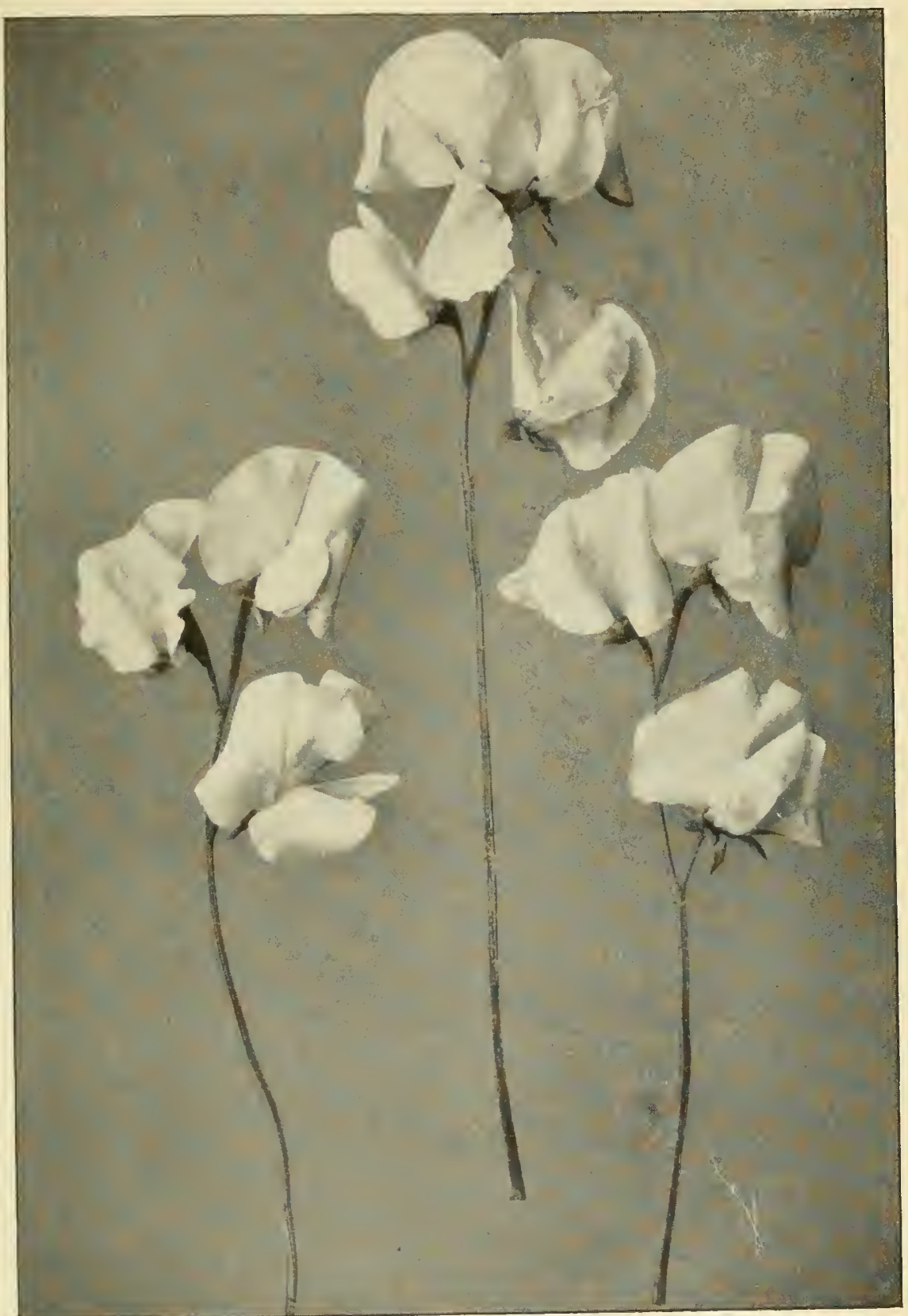




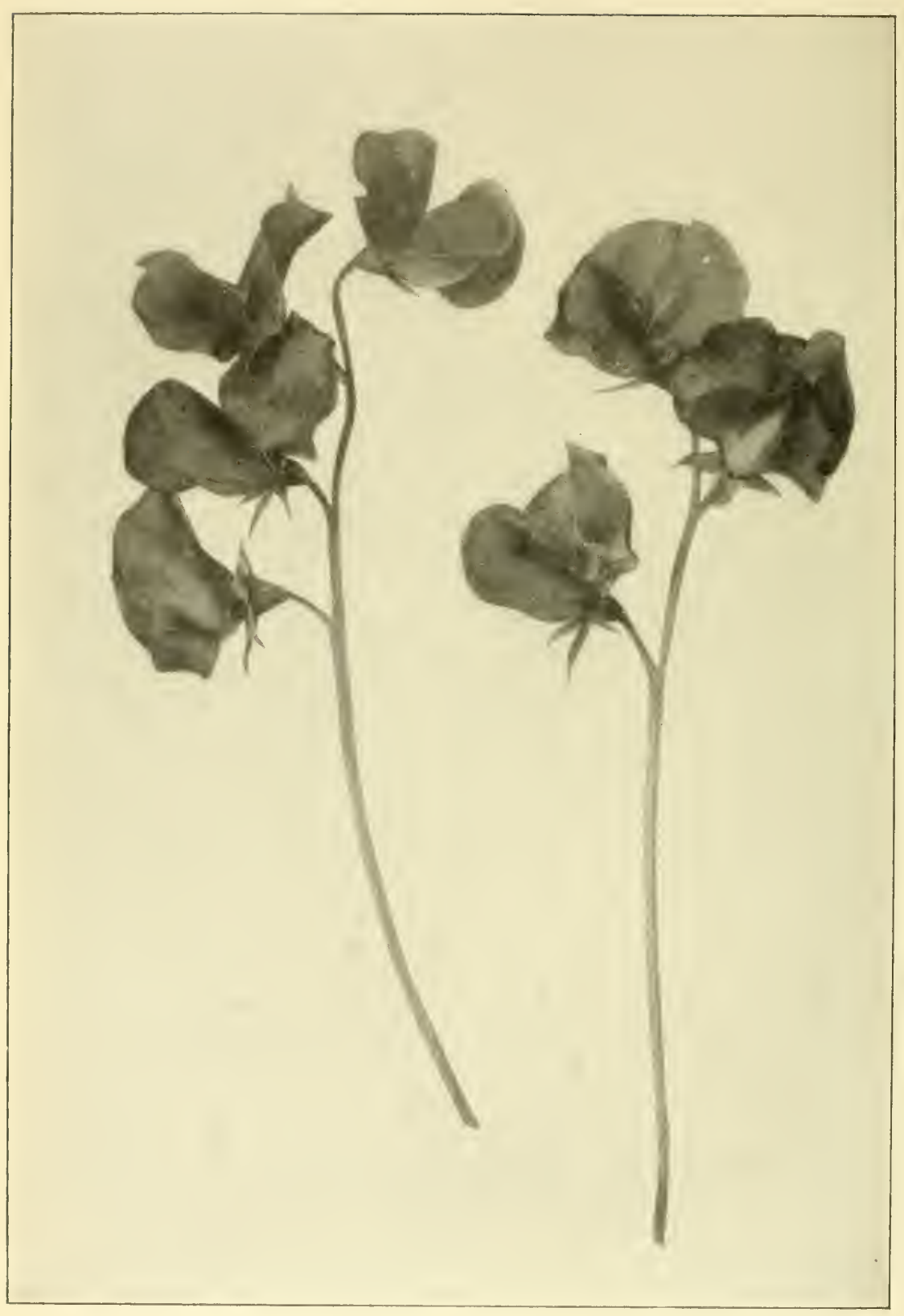


Comparison - At this station this variety was much superior to Paradise Ivory. Remarks - A very beautiful variety; deserves to be included in all collections.

\section{MAY PERRETT SPENCER}

Originated by Malcolm.

Introduced by Malcolm, 1913.

Donated by Boddington, I9I3.

Description in brief - Light pink on a buff ground.

Description in detail - Color of standard and wings light buff, flushed with pink. Flower of medium size, grandiflora form; standard of medium size, erect; wings short and broad, concealing the keel. Flowers two to three, on long, strong stems. No fragrance. Bloom moderate. Sunproof. Plant of tall, slender growth.

Leaflets broad, round, dark green.

Synonyms - Is May Perrett.

Remarks - Stock true to type.

\section{PARADISE BEAUTY}

Originated by Miss Hemus.

Introduced by Niss Hemus, 1910.

Donated by Miss Hemus.

Description in brief - A fairly large, waved variety, of ivory color.

Description in detail - Color rosy white $8(\mathrm{I}-2)$; wings $8\left(3^{-}+\right)$. Flower large; standard large, slightly waved; wings medium to large, long and broad, concealing the keel. Flowers two to four, on long, strong stems. Fragrant. Bloom profuse. A garden or market variety. Plant of moderately strong growth. Tendrils colored; color in axils. Seed black.

Comparison - Has more substance and less pink color in the flowers than Paradise Ivory.

Remarks - A fixed stock.

\section{PARADISE IVORY}

Originated by Miss Hemus.

Introduced by Miss Hemus, 1907 .

Donated by Miss Hemus, Stark, I9 Io.

Description in brief - A medium to large, ivory-white, waved variety.

Description in detail - Color fleshy white $9(\mathbf{I}-2)$. Standard of medium size, slightly waved; wings broad and medium long, concealing the keel. Flowers two to four, usually three, on long, moderately stout stems. Extremely, fragrant. Bloom profuse. A home or market variety. Plant of medium height, strong. Color in axils of leaves. Seed black.

Comparison - Lady Knox, a later introduction, surpasses this variety.

Originated by Stark.

\section{PRIMROSE BEAUTY}

Donated by Stark, I9I2.

Description in brief - A large, waved, primrose variety.

Description in detail - Color of standard and wings yellowish white I 3 (2-3). Flower very large, waved form; standard very large, slightly waved; wings long and broad. Flowers three, equidistant on long, strong stems. Moderately fragrant. Plant of very tall, strong growth. Leaflets broad, pointed; tendrils green.

Comparison - Dobbie's Cream opens with more yellow in the flowers. Appears to be Mrs. Collier in Spencer form.

Remarks - The finest variety of this color. 


\section{PRIMROSE PARADISE}

Originated by Miss Hemus.

Introduced by Miss Hemus, 1908.

Donated by Miss Hemus, I910.

Description in brief $-\Lambda$ large, waved, primrose varicty.

Description in detail - Color of standard creany white 10 (2-3); wings 1o (2). Plant of medium height and strong, healthy growth. Seed whitc.

Comparison - Similar to Primrose Spencer.

Remarks - A pure stock.

\section{PRIMROSE SPENCER}

Originated by L. C. Routzahn.

Introduced by Burpec, 1908.

Donated by Boddington, Henderson, Morse, Rawson, I910; Burpee, 1911, 1912, I913.

Description in brief - A large, waved, primrose variety, for garden, market, or exhibition purposes.

Descriplion in detail - Front of standard yellowisl white 13 (2-3), back I3 (4); wings $13(\mathbf{1}-2)$. Standard large, Spencer-waved; wings very large, long and broad, concealing the keel. Flowers two to four, well arranged on long, strong stems. Mloderate fragrance. Bloom profuse, continuous. Plant of tall, vigorous growth. Seed white.

Comparison - Similar to Clara Curtis (Bolton, I908).

Remarks - The standard variety of this color.

\section{QUEENIE}

Originated by Deal.

Introduced by Deal, 1009.

Donated by Deal, 1910, 1912.

Description in brief - A medium to large, ivory-white, waved variety.

Description in detail - Color of standard shades from rosy white $8(2-3)$ to pale rosy pink $129(2-3)$ at the edge; wings lilacy white $7(1-2)$. Flower large; standard large, slightly waved; wings long and broad, concealing the keel. Flowers two to four, on long, moderately strong stems. Fragrant. Plant of moderate growth. Tendrils green. Sced black.

Comparison - Resembles Paradise Ivory.

Remarks - Badly unfixed in 1910. Fixed stock in 1912.

\section{QUEEN VICTORIA SPENCER}

Originated by

Introduced oy Burpee, I909.

Donated by Morse, I9I0; Burpee, I9II, I9I2.

Description in brief - A large, waved, black-seeded, primrose variety.

Description in detail - Flower opens lilacy white 7 (4), changing to ycllowish white

I3 $(2-3)$. Standard large, Spencer-waved; wings long and broad, concealing the keel. Flowers three, on strong stems of medium length. Moderate fragrance. Plant of tall, strong, healthy growth. Seed black.

Comparison - Paradise Ivory is similar.

Kemarks - This variety, having dark-colored seed, is selected as the best cream variety, owing to difficulty in germinating varicties having light-colored seed. 


\section{SEAFOAM}

Originated by Cole.

Introduced by Cole, igio.

Donated by Cole, igio.

Description in brief - A medium to large, ivory-white, waved variety.

Description in detail - Color creamy white $10(\mathrm{I}-2)$. Standard of medium size, slightly waved; wings long and broad, concealing the keel. Flowers two to four, on long, strong stems. Fragrant. Bloom profuse. A garden or market variety. Plant of moderately strong, healthy growth. Tendrils colored; color in axils of leaflets.

Comparison - The wings are a deeper and brighter pink than those of Paradise Ivory. Remarks - A fixed stock.

\section{Cream-Pink (Deep)}

\section{CONSTANCE OLIVER}

Originated by W. Lumley.

Introduced by Lumley, 1908.

Donated by Dobbic, 1910.

Description in brief - A large, waved, cream-pink variety.

Description in detail - Color of standard peach blossom (pink suffused with cream) 127 ( I); wings bright rose I 28 (I). Flower very large; standard very large, much waved; wings long and broad, concealing the keel. Flowers two to four, usually three, on long, strong stems. Fragrant. Bloom profuse. Plant of medium height and strong growth. Tendrils colored.

Comparison - Nell Gwynne is similar but is not fixed. Paradise Constance Oliver is an unfixed strain of this variety.

Remarks - A pure stock.

\section{DORIS USHER}

Originated by A. E. Usher.

Introduced by Sutton, I9I.

Donated by Sutton, 1912.

Description in detail - Color of standard rosy pink I I 8 (I-2); wings rosy pink I I 8 (2-3). Flower of medium size, waved form; standard of medium size, slightly waveu; wings short and broad, spreading. Flowers two to three, equidistant on long, strong stems. Moderately fragrant. Bloom scant. Sunproof. Plant of tall, strong growth. Leaflets broad, pointed; tendrils colored.

Comparison - Smaller than Mrs. Routzahn, but similar to it. Smaller flower, and lighter, softer, more even color, than Constance Oliver.

\section{MARY GARDEN}

Originated by Morse.

Introduced by Morse, I9I2,

Description in brief - A large, waved, double, cream-pink variety.

Description in detail - Color of standard rosy pink $118(\mathrm{I}-2)$; wings same, with tinge of Tyrian rose I55 (I) on edge. Flower very large, waved form; standard very large, much waved, often double; wings long and broad, concealing the keel. Flowers three, irregular on long, slender stems. Moderately fragrant. Sunproof. Plant of tall, slender growth.

Comparison - Burpee called a strain of this variety Duplex Mary Garden.

Remarks - Stock contained color rogues. 


\section{MINNIE FURNELL}

Originated by W. E. Alsen.

Donated by Alsen, I9I2.

Description in brief - A pale pink, with a cream blotch at base of standard.

Description in detail - Color of standard light rose 128 (I or lighter), with cream

blotch at base; wings light rose I28 (I inside and 2-3 outside). Flower large, waved form; standard large, slightly waved. Flowers two to three, equidistant on strong stems of medium length. Moderately fragrant. Bloom scant in 1912. Sunproof. Plant of tall, strong growth. Leaflets broad, pointed; tendrils colored.

\section{MIRIAM BEAVER}

Originated by Morse.

Introduced by Burpee, I9Io.

Donated by Burpee, Morse, Rawson, 1910.

Description in brief - A large, Spencer-waved variety, of unusual color.

Description in detail - The predominating color was as follows: standard salmonpink 126 (I-2); wings 126 (1), shading to $126(2-3)$ at base. Standard large, Spencer-waved; wings waved, long and broad. Flowers two to four, usually three, on long, strong stems. Fragrance slight. Bloom free. Sunproof. Plant of medium height and stout, healthy growth. Seed large, dark brown.

Comparison - Deeper salmon-pink than Mrs. Routzahn.

Remarks - Very unfixed.

\section{MRS. GIBBS BOX}

Originated by James Box.

Introduced by Box, 1912.

Donated by Box.

Description in brief - Large, waved, rosy pink on a cream ground.

Description in detail - Color of standard rosy pink I I 8 (1), wings 118 (2-3), on a cream grouncl. Flower large, waved form; standard large, slightly waved; wings long and broad, spreading. Flowers two to three, equidistant on long, strong stems. Little or no fragrance. Moderately productive. Plant of very tall, stout growth. Leaflets broad, pointed; tendrils green.

Comparison - Is a lighter pink and has more eream than Constance Oliver. Has better stem and is more productive than Minnic Furnell.

\section{NATOMA}

Originated by Morse.

Introduced by Morse, 1912.

Donated by Morse, igra.

Description in brief - $\mathrm{A}$ large, salmon-buff, waved varicty.

Description in detuit - Color of standard pale rosy pink $129(2-3)$, inside tinted lilac-rose; wings lilac-rose 152 ( 1 or lighter), sometimes with violet-rose tints. Flower large, waved form; standard large, waved, sometimes double; wings short and broad, waved. llowers irregular on very long, strong stems. Moderately fragrant. Moderately procluctive. Sumproof. Plant of very tall, strong growth. leaflets broad, pointed.

Comparison - Appears to be a Venus of Spencer form. 
Originated by Stark.

\section{NELL GWYNNE}

Donated by Stark, I910.

Introduced by Stark, 1908.

Description in brief - A large, cream-pink, waved variety.

Comparison - Similar to Constance Oliver.

Remarks - One half or more of this stock were rogues of the color of John Ingman.

Originated by Stark.

\section{OLIVE RUFFELL}

Donated by Stark (selected stock), 19 I0.

Description in brief - A large, waved, rosy salmon variety.

Description in detail - Color of standard shades from lilacy white 8 (4) to bright rose $128(2-3)$ at base; wings purple-rose 150 (I). Standard and wings large and waved. Flowers two to four, usually three, on long stems. Fragrant. Bloom profuse. Plant of strong, healthy growth. Tendrils colored; color in axils of leaves. Comparison - This is a deeper-colored Constance Oliver. Remarks - Not quite fixed when grown here in I9Io.

\section{Cream-Pink (Pale)}

Originated by Aldersey.

Introduced by Aldersey, I9I2.

Donated by Aldersey (Aldersey's No. I5I), I9I2.

Description in bricf - "A creamy pink self." - Sweet Peas Up to Date.

Description in detail - Color of standard salmon-pink I26 (I); wings bright rose 128 (I-2), brighter on edge. Flower large, waved form; standard large, waved; wings long and broad, spreading. Flowers equidistant on strong stems. Moderately fragrant. Moderately productive. Sunproof. Plant of tall, stout growth. Comparison - More cream than Constance Oliver and more rosy pink than Doris Usher.

Originated by Bolton.

\section{CORONATION}

Donated by Sydenham, I9I3.

Description in brief - A large, pale cream-pink variety.

Description in detail - Color of standard and wings creamy white Io (I), overlaid with purple-rose 150 ( 1 ); the back of the standard is uniform with the color of the front, while the back of the wings is a deeper rose. Flower large, waved form; standard large, waved; wings short and broad, concealing the keel. Flowers three, equidistant, close, on strong stems of medium length. Moderately fragrant. Bloom profuse. Sunproof. Plant of very tall, stout growth. Leafletsbroad, dark green; tendrils colored.

Remarks - There are many varieties very nearly like this, yet it is worthy of trial by growers of sweet peas.

\section{ELLA KELWAY}

Originated by

Introduced by Kelway, I9I2.

Donated by Kelway, I912, I9I3.

Description in brief - A large, waved, pale cream-pink variety.

Description in detail - Color of standard and wings creamy white $10(2-3)$, overlaid and edged with light purple-rose; back of standard lighter in color and without 
the edging; back of wings brighter pink. Flower large to very large, waved form; standard large, much waved; wings short and broad, concealing the keel. Flowers three to four, on strong stems of medium length. Very fragrant. Moderately productive. Sunproof. Plant of tall, slender growth. Leaves broad, pointed, dark green.

Remarks - A fine variety, but with such as Mrs. Routzahn, Mrs. Henry Bell, and Mrs. Hugh Dickson there seems no room for it. Stock true to type.

\section{GLADYS BURT}

Originated by Unwin.

Introduced by Unwin, 1908.

Donated by Unwin, I9I0.

Description in brief - A very large, waved, salmon-pink variety. Suitable for all purposes.

Description in detail - Color mauve-rose 153 (2-3), on a primrose ground. Flower large to very large; standard large, very waved; wings long and broad, concealing the keel. Flowers three, on long, strong stems. Fragrant. Bloom profuse. Plant of fairly tall, vigorous, healthy growth. Tendrils colored; color in axils of leaves. Seed dark brown, small, round.

Comparison - Color is between that of Mrs. Routzahn and Constance Oliver.

Remarks - A pure stock.

\section{HOLDFAST BELLE}

Originatud by Miss Hemus.

Introduced by Miss Hemus, 1910.

Donated by Miss Hemus, 1910.

Descriplion in brief - A large, waved, cream-pink variety.

Comparison - Very similar to Mrs. Routzahn.

Remarks - A pure stock.

Originated by Deal.

JULIET

Donated by Deal, I912.

Description in brief - Large, waved, rosy pink on a cream ground.

Description in detail - Color of standard rosy pink I 18 (1), on a pale yellow ground; wings rosy pink ir 8 (2). Flower large, waved form; standard large, waved slightly; wings short and broad, spreading. Flowers irregular on long, strong stems. No fragrance. Bloom productive. Sunproof. Plant of tall, strong growth.

Comparison - Less vivid than Mrs. Routzahn at all stages. Worthy of trial because it gives a wider range of color within this group.

\section{LADY MILLER}

Originated by Malcolm.

Introduced by Dobbie, 1913.

Donated by Millcolm, I9I2.

Description in brief - "Apricot on cream suffused pink." - Dobbic's catalogue.

Descripticn in detail - Color of standard and wings shrimp pink 75 ( 1 or lighter).

Flower large, waved form; standlirel large, slightly waved, sometimes double; wings long and broat, concealing the keel. Flowers three to four, irregular on long, strong stems. Morlerately fragrant. Productive. Sunproof. Plant of tall, slender growth. Petioles and calyx brownish; tendrils colored. 
Comparison - Better than Cherub. Not so large nor so much waved as Constance Oliver.

Remarks - Stock pure, true.

\section{MRS. HENRY BELL}

Originated by Bolton.

Introduced by Bolton, I 908.

Donated by Rohnert, I9I2.

Description in brief - Large, waved, rich pink on a cream ground.

Description in detail - Color of standard bright rose $\mathrm{I} 28$ (I), with cream base; wings I 28 (I), with considerable lilac-rose on the edges. Flower large, waved form; standard large, slightly waved; wings long and broad, spreading. Substance good. Flowers two to three, irregularly spaced on strong stems of medium length. Moderately fragrant. Bloom profuse. Plant of tall, strong growth. Leaflets broad, pointed; tendrils green.

Comparison - More purplish pink than Mrs. Routzahn and not so much pink as Holdfast Belle.

\section{MRS. HUGH DICKSON}

Originated by Dobbie.

Introduced by Dobbie, I9ro.

Donated by Dobbie, I9I0; Burpee, I9I I; Morse, I912.

Description in brief - A very large, cream-pink, waved variety.

Description in detail - Color of standard lilac-rose $\mathbf{I} 30$ (I) on a creamy white ground; wings salmon-pink I 28 ( $\mathrm{r}$ ). Standard very large and very waved; wings long and broad, partly open. Substance good. Flowers three to four, on long, strong stems. Fragrant. Bloom free. Plant of strong growth. Seed large, round, black.

Comparison - This variety is earlier and has lighter primrose color than Mrs. Routzahn. Remarks - A true stock. Commended.

\section{MRS. ROUTZAHN}

Originated by

Introduced by Burpee, I909.

Donated by Boddington, Burpee, Morse, I9I0; Burpee, I9 I I, I9I 2.

Description in brief - A very large, cream-pink Spencer, suitable for all purposes.

Description in detail - Color pale lilac-rose 130 (2) on a yellowish white ground. Standard very large and very waved; wings long and broad, partly open. Flowers two to four, usually three, gracefully placed on long, strong stems. Fragrant. Bloom profuse, continuous. Plant of medium height and strong, healthy growth. Color in axils of leaves.

Remarks - All stocks pure. The standard variety of this color.

\section{MRS. STEWART CHAMPION}

Originated by Bide.

Introduced by Bide, I9II.

Donated by Bide, гіг2.

Description in brief - A large, waved, cream-pink self.

Description in detail - Color of standard crushed strawberry 109 (I); wings Rose Neyron red II9 (I). Flower large, waved form; standard large, waved; wings long and broad, spreading. Flowers three, irregularly spaced on long, strong stems. Mloderately fragrant. Productive. Sunproof. Plant of very tall, strong growth. Leaves very lark green; leaflets broad, often round; tendrils green. 
Comparison - $\Lambda$ superior strain of Mrs. Routzahn.

Remarks $-\Lambda$ true stock.

\section{QUEEN MARY}

Originated by King.

Introduced by King, I910.

Donated by King, 1913.

Description in brief $-\Lambda$ large, waved, cream-pink variety.

Description in detail - Color of standard creamy white Io (I), overlaid with lilac-rose I30 (1); wings salmon-pink 128 ( 1 ). Flower large, waved form; standard large, waved; wings short and broad, concealing the keel. Flowers three, equidistant, close, on strong stems of medium length. Moderately fragrant. Bloom profuse. Sunproof. Plant of tall, stout growth. Leaflets broad, rounded, dark green.

\section{SUTTON'S QUEEN}

Originated by T. Rothera \& Co.

Introduced by Sutton, 1908.

Donated by Boddington, 1910; Sutton, 1912.

Description in brief - Medium to large, slightly waved variety.

Description in detail - Color pale lilac-rose 130 (I) on creamy white 10 (I), changing

to almost white. Standard medium to large, slightly waved; wings of medium

size, partly open. Flowers two to three, on medium stems. Moderate fragrance.

Bloom not continuous. Plant below medium lieight, healthy.

Comparison - Inferior to Mrs. Routzahn.

Remarks - A mixed stock containing some plants of the color of E. J. Castle and Stella

Morse in 1910. A pure stock from introducers in 1912.

\section{W. T. HUTCHINS}

Originated by

Introduced by Burpee, 1910.

Donated by Burpee, Morse, I9I0.

Description in brief - A large, cream-pink, waved varicty.

Description in detai! - Color yellowish white I3 (4), flushed with pale lilac-rose I30

$(2-3)$, with decper shade around the edges. Standard large, waved; wings long and

broald, waved, concealing the kecl. Flowers three, on long, strong stems. Fra-

grant. Plant of tall, strong growth. Color in axils of leaves. Seed black.

Remarks - One stock produced flowers with more pink color.

\section{Crimson}

\section{CAPTIVATION SPENCER}

Originated by Morse.

Iutroduced by Morse, Burpec, 1912.

Donated by Burpee, Boddington, 1912.

Description in brief - " A rich rosy wine red." - Sweet Peas Up to Date.

Description in detail - Color of standard amaranth-red $168(\mathrm{I}-3)$; wings rosy magenta I $69(\mathrm{I}-2)$, veined darker. Flower large, waved form; standard large, slightly waved; wings long and broad, spreading or drooping. Substance good. Flowers two, on slender stems of medium length. Slightly fragrant. Not productive. Plant of medium height and slender growth. Leaflets broud, pointed; tendrils green.

Comparson - Similar to Rosie Adams. 
Originated by Deal.

\section{CRIMSON GIANT}

Donated by Deal, I9I2.

Introduced by Deal, I 9 I 1 .

Description in detail - Color of standard crimson-red II 4 ( $1-2)$, veined darker; wings crimson-red II4 (I-2), with a slight purplish tinge. Flower large, waved form; standard large, slightly waved; wings large, long and broad. Flowers two to three, on strong stems of medium length. Slightly fragrant. Moderately productive. Burns slightly. Plant of tall, stout growth. Leaflets broad, pointed. Comparison - Is more crimson and burns more thin King Edward Spencer.

\section{CRIMSON PARADISE}

Originated by Miss Hemus.

Introduced by Miss Hemus, 1909.

Donated by Miss Hemus, I910.

Description in brief - A large, waved, crimson, all-purpose variety.

Description in detail - Color of standard carmine-purple I56 (3-4); wings I56 (I).

Flower large to very large; standard very large, Spencer-waved; wings long and broad. Flowers two to four, on long, strong stems. Slight fragrance. Bloom profuse, continuous. Not sunproof. Plant of tall, vigorous growth.

Comparison - Superior to any of the strains of King Edward Spencer, except that it is not sunproof.

\section{G. C. WAUD}

Originated by Cole.

Introduced by Cole, 19-0.

Donated by Cole, r9io.

Description in brief - A large, waved, crimson-scarlet, garden variety.

Description in detail - Color of standard carmine-purple 156 (I-2); wings I56 (I).

Standard large, slightly waved; wings large, waved, partly open. Flowers three, on long, strong stems. Moderate fragrance. Bloom profuse. Burns slightly.

Plant of strong, healthy growth. Seed large and black.

Comparison - Similar to King Edward Spencer.

Remarks - Stock not fixed; contained one plant of John Ingman and one of Coccinea.

\section{KING EDWARD SPENCER}

Originated by

Introduced by Burpee, I909.

Donated by Boddington, Burpee, Morse, Unwin, I9I0; Burpee, I9II, I9I 2.

Description in brief - A large, carmine-scarlet, waved, garden or market variety.

Description in detail - Color of standard carmine-purple 156 (3-4); wings 156 (I).

Standard large, moderately waved; wings very long and broad, not waved, concealing the keel. Flowers two to four, usually three, on long, strong stems. Very slight fragrance. Bloom profuse, continuous. Plant of tall, strong, healthy growth.

Comparison - The King is of superior form but is less resistant to the sun.

Remarks - All strains pure. Finest strains from Burpee and Morse.

\section{LIBERTY}

Originated by

Introduced by Lumley, I910.

Donated by Farquhar, 1913.

Description in detail - Color of standard crimson-red II4 (I-2), veined darker; wings amaranth-red I68 (I-2), turning crimson, slightly darker on back. Flower large, 
waved form; stantard large, slightly waved; wings large, long and broad, concealing the keel. Flowers three, on short stems. No fragrance. Moderately prouluctive. Burns. Plant of medium height and slender growth. Leaflets broikl, rount, dark green; tendrils green.

Remarks - Stock pure, true.

\section{MRS. DUNCAN}

Originated by Stark.

Introduced by Stark, I9IO.

Donated by Stark, I9I0; Boddington, I912.

Description in brief - A large, waved, crimson, garden or market variety.

Description in detuil - Color of standard crimson-red IIt (2-3); wings carminepurple 156 (I). Standard large to very large, moderately waverl; wings long and broad, concealing the keel. Flowers two to four, ustally three, on long, strong stems. Very slight fragrance. Bloom profuse, continuous. Nearly sunproof. Plant of tall, strong, healthy growth.

Comparison - Not waved so much as the strains of The King.

Remarks - A fixed stock. Some flowers showed signs of burning, but did not blacken.

\section{ORION}

Originated by Holmes.

Introduced by Sydenham, 1912.

Donated by Sydenham, I912.

Description in brief - " A large, deep reddish crimson." - Sweet Peas Up to Date.

Description in detail - Color of standard and wings lilac-purple $160(2-3)$. Flower large, waved form; standard large, slightly waved; wings short and broad, spreading. Flowers three, irregularly placed on stems of medium length. Moderate fragrance. Moderately productive. Sunproof. Plant of tall, strong growth. Leaflets broad.

\section{ROSIE ADAMS}

Originated by Thomas Stevenson.

Introduced by Stevenson, H. J. Wright, I 908 .

Donated by Farquhar, 1913.

Description in detail - Color of standard amaranth-red I68 (I-2); wings amaranth-red to deep purple; both standard and wings veined darker. Flower medium to large, waved form; standard large, waved; wings short and broad, concealing the keel. Flowers three, irregular on long, strong stems. No fragrance. Bloom profuse. Sunproof. Plant of tall, stout growth. Leaflets broad, pointed, dark green; tendrils green.

Comparison - Similar to Captivation Spencer.

Remarks - Stock mixed, one white rogue.

\section{RUBY PALMER}

Originated by

Introduced by Dobbie, 191.t.

Donated by Dobbie, 1912.

Description in detail - Color of standard and wings lilac-purple $160(4)$, inside of wings shading $160(\mathrm{I}-2)$. Flower large, waved form; standard large, slightly waved, with slightly auriculate base; wings large, long and broad. Substance good. Flowers three, on medium stems. Moderately fragrant. Moderately productive. Sumproof.

Comparison - $\Lambda$ trifle more purplish than King Edward Spencer. Darker than Marie Corelli. 


\section{SUNPROOF KING}

Originated by Bide.

Introduced by Bide, I9I0.

Donated by Bide, I9Io.

Description in brief - A very large variety, for garden, markct, or exhibition use.

Description in detail - Color of standard carmine-purple 156 (3-4); wings 156 (1). Standard very large, much waved; wings long and broad, waved, partly open. Flowers two to four, on long, strong stems. Mild fragrance. Bloom profuse, continuous. Sunproof. Plant of strong, vigorous growth.

Remarks - A fixed stoek. Everything considered, this was the finest strain of this color in 1910 .

\section{THE KING}

Originated by Dobbie.

Introduced by Dobbie, I909.

Donated by Dobbie, I9Io.

Description in brief - A very large, waved variety.

Description in detanl - Color of standard carmine-purple I56 (3); wings I 56 (I). Standard very large, very waved; wings large, waved, partly open. Flowers three, equidistant on long, strong stems. Very slight fragrance. Plant of vigorous, healthy growth.

Comparison - Superior to King Edward Spencer in size and form, but the flowers turn black under a hot sun.

Remarks - A fixed stock.

\section{Fancy}

\section{AFTERGLOW}

Originated by Bolton.

Introduced by Bolton, I9I I.

Donated by Burpee, I9I3.

Description in brief - Reddish mauve, with violet wings.

Description in detail - Color of standard purplish mauve I86 (+ or darker); wings bright violet $198(2-3)$. Flower large, waved form; standard large, much waved; wings long and broad, concealing the keel. Flowers three to four, equidistant, close, on strong stems of moderate length. Moderately fragrant. Moderately productive. Sunproof. Plant of medium height and stout, healthy growth. Leaflets broad, pointed, dark green; tendrils clinging.

\section{CHARLES FOSTER}

Originaled by Bolton.

Introduced by Bolton, I9I I.

Donated by Burpee, I9I3.

Description in brief - " Pastel pink shaded lavender." - Sweet Peas Up to Date.

Description in detail - Color bright rose 128 (I-2) flushed with lavender, deeper at base; wings bright rose $128(\mathbf{I}-2)$, with less lavender. Flower large, waved form; standard large, waved, with round top and broad base; wings large, long and broad, concealing the keel. Flowers three to four, equidistant, elose, on short, strong stems. Moderately fragrant. Moderately productive. Burns slightly. Plant of medium height and stout, healthy growth. Leaflets broad, pointed, dark green.

Remarks - Stock pure, true to type. 


\section{Lavender}

Originated by Henry Ohn.

\section{ASTA OHN}

Donated by Morse. Rawson.

Description in brief - Large, waved, lavender suffused with mauve.

Description in detail - Standard purplish mauve 186 (1-2), changing to ageratum blue 201 (2); wings pale light lilac 187 (I), changing to Parma violet 200 (3-4). Standard large, waved; wings very large, waved, long and broad, concealing the keel. Flowers two to three, on strong stems of medium length. Fragrant. Bloom profuse, continuous. A garden and market variety. Plant of medium height and stout, healthy growth. Sced mottled.

Comparison - At this station this variety always has more mauve color than Frank Dolby, although it changes to blue.

\section{BERTRAND W. DEAL}

Originated by Deal.

Introduced by Deal, 1910.

Donated by Deal, I9I I.

Description in brief - A waved, rosy mauve variety.

Description in detail - Color of standard pale lilac-rose $178(2-3)$; wings pale light lilac I 87 (I). Flower very large, waved form; standard very large, much waved; wings very large, long and broad, spreading. Flowers three, on very long stems of medium strength. Moderately fragrant. Moderately productive. Plant of moderately tall, slender growth. Leaflets broad, pointed; tendrils green.

\section{DORA}

Originated by

Introduced by Bath.

Donated by Bath, I9r2.

Description in brief - A waved, lavender variety.

Description in detail - Color of standard bishop's violet $\mathrm{I} 89(\mathrm{I}-2)$, veined with light violet $198(3-4)$; wings bright violet 198 (I). Flower large, waved form; standard large, slightly waved; wings long and broad, spreading. Flowers on medium, slender stems. Very fragrant. Moderately productive. Burns slightly and is badly injured by wet weather. Plant of tall, strong growth. Leaflets broad, pointed.

Comparison - Similar to Asta Ohn.

\section{DRAGONFLY}

Originated by Aldersey.

Introduced by Aldersey, I9I3.

Donated by Aldersey, I9I2.

Description in brief - "Lavender on cream ground, wings lavender." - Sweet Peas Up to Date.

Description in detail - Color of standard and wings bright violet 198 (I), with a rosy tinge. Flower large, waved form; standard large, slightly waved; wings long and broad, spreading. Substance poor. Flowers two to three, on long stems. Moderately fragrant. Bloom moderate. Plant of tall, strong growth.

\section{FELICITY}

Originated by - _ -

Introduced by Bath, 1913.

Donated by Bath, I9I 2.

Description in brief - "A large waved lilac, flushed pink." - Introducer's description. 
Description in detail - Color of standard and wings heliotrope I88 (I-2); standard sometimes darker on back near base. Flower of medium size, waved form; stanclard of medium size, slightly waved; wings long and broad. Substance poor.

Flowers three, on strong stems of medium length. Moderate fragrance. Bloom medium. Sun fades badly. Plant of tall, strong growth.

Comparison - Lighter than Tennant Spencer. Distinct from Irish Belle.

\section{FLORENCE NIGHTINGALE}

Originated by Hugh Dickson.

Introduced by Burpee, I9II.

Donated by Burpee, I9II, I9I2, I9I3.

Description in brief - A large, waved, clear lavender self.

Description in detail - Color of standard bright violet-purple $190(\mathbf{I}-2)$; wings light

bluish violet $202(3-4)$. Flower large, waved form; standard large, slightly waved; wings long and narrow. Flowers three to four, irregularly spaced on long, strong stems. Moderately fragrant. Bloom profuse. Plant of tall, slender growth. Remarks - A worthy variety.

\section{FRANK DOLBY}

Originated by Unwin.

Introduced by Unwin, and Watkins \& Simpson, 1907.

Donated by Boddington, Rawson, Unwin, and Watkins \& Simpson.

Description in brief - A fairly large, lavender variety of Unwin form.

Description in detail - Standard opens violet-mauve $195(\mathrm{I}-2)$, changing to Parma violet $200(\mathrm{I}-3)$; wings open lilac-mauve I99 (I), changing to ageratum blue $20 \mathrm{I}$ $(\mathbf{I}-2)$. Standard large, slightly waved; wings large. Flowers two to four, on long, strong stems. Fragrant. Bloom very profuse, continuous. A garden or market variety. Plant of medium height and strong, vigorous growth. Color in axils of leaves. Seed dark brown, mottled, small to medium in size.

\section{FRANK UNWIN}

Originated by Unwin.

Introduced by Unwin, I910.

Donated by Unwin, I9Io.

Description in brief - A large, waved variety, soft lavender suffused with mauve.

Description in detail - Color of standard bluish lilac 183 (I-2); wings heliotrope 188

$(2-3)$. Standard large, Spencer-waved; wings of medium size, waved, short and broad. Flowers two to three, on stems of medium length and strength. Fragrant. Bloom profuse. A garden variety. Plant of medium height and slender growth. Seed dark brown, of medium size.

Comparison - This variety is distinct from Frank Dolby.

Remarks - A fixed stock. Late in the season some flowers are mottled.

\section{IRISH BELLE}

Originated by Dickson.

Introduced by Burpee, I9I2.

Donated by Burpee, I9I 2.

Description in brief - " Rich lilac flushed pink."- Burpee's catalogue.

Description in detail - Color of standard and wings purplish mauve $\mathbf{1} 86(\mathbf{I}-2)$. Flower large, waved form; standard large, slightly waved; wings large, long and broad. Flowers three, irregularly spaced on long stems of medium strength. Noderate fragrance. Moderately productive. Burns slightly. Plant of medium height and slender growth. Tendrils green. 
Comparison - Lighter than Florence Nightingale or Mauve Queen, and darker than Felicity or Orchicl.

Synonyms - Dream is another name for this variety.

Remarks - Received alward of merit from American Sweet Pea Society in Igr $\mathbf{I}$.

\section{IVANHOE}

Originated by Dohbic.

Introduced by Dobbie, I9I I.

Donated by Dobbic, I912.

Description in brief - Soft heliotrope-mauve.

Description in detail-Color of standard purplish mauve $\mathbf{1} 86(\mathbf{I}-2)$, shading into heliotrope I88 (I) in center; wings heliotrope I88 (I). Flower very large, waved form; standard very large, much waved, slightly auriculate; wings large, long and broad. Substance good. Flowers three, equidistant on long, strong stems. Very fragrant. Bloom profuse, continuous. Sunproof. Plant of tall, stout growth. Leaflets broad, pointed.

Comparison - Is lighter matuve and has more heliotrope than Betty. Larger and paler than Tennant Spencer.

\section{LAVENDER QUEEN}

Originated by

Introduced by Dobbie.

Donated by Dobbie, I912.

Description in 3rief - A very large, waved, lavender variety.

Description in detail - Color of standard bright violet 198 (1), flaked darker; wings ageratum blue $20 \mathrm{I}$ ( 1 ). Flower very large, waved form; standard very large, much waved; wings large, long and broad. Substance good. Flowers three to four, equiclistant on long, strong stems. Very fragrant. Bloom profuse. Plant of tall, stout growth. Leaftets broad, pointed; tendrils green.

Comparison - Has more lavender and is of slightly better growth than Asta Ohn. Is similar to Florence Nightingale.

\section{LAVENDER SPENCER}

Originated by Stark.

Introduced by

Donated by Stark, for advance trial, 1910.

Description in brief - A moderately large, waved, lavender variety.

Description in detail - Color of standard heliotrope I 88 (I-2); wings I 88 (I). Standard moderately large, Spencer-waved; wings waved, long and broad. Flowers two to three, on long, strong stems. Fragrant. Bloom profuse. Plant of medium height and slender, healthy growth. Tendrils colored; color in axils of leaves. Seed mottled.

Remarks - $\Lambda$ pure stock.

Originated by Bath.

\section{LILAC QUEEN}

Donated by Bith, I9IO.

Description in brief - I lilac variety, of Unwin form and size.

Description in detail - Standard purplish mauve I86 (2-3); wings I86 (1). Flower medium large; standard medium large, Unwin type, erect; wings medium, hooled, long and broad, concealing the keel. Flowers two, on long stems of medium strength. Fragrant. Bloom profuse. Sunproof. A garden variety. Plant of medium height and moderately strong, healthy growth. Seed small, wrinkled. 
Originated by Malcolm.

MALCOLM'S NO. I4

Donated by Dobbie, I912.

Introduced by

Description in brief - A very large, waved, heliotrope and bluish violet variety.

Description in detail - Color of standard heliotrope I 88 (3-4); wings light bluish violet 202 (I). Flower very large, waved form; standard very large, often much waved, with broad base; wings large, long and broad. Substance good. Flowers three, irregularly placed on strong stems of medium length. Not fragrant. Bloom moderate. Sunproof. Plant of tall, stout, healthy growth. Leaflets broad, pointed; tendrils green.

Comparison - Less mauve than Asta Ohn. Similar to Florence Nightingale.

\section{MANDOLINE}

Donated by Dobbie, 1912.

Description in brief - A very large, reddish lavender flower.

Description in detail - Color of standard and wings bright violet 198 (1-2). Flower very large, waved form; standard very large, often double, slightly waved, with slightly auriculate base; wings very large, long and broad. Substance good. Flowers three, equidistant on long stems of medium strength. Moderate fragrance. Bloom profuse. Plant of medium height and slender growth.

Comparison - Similar to Asta Ohn.

\section{MASTERPIECE}

Originated by Malcolm.

Introduced by Dobbie, I9 10.

Donated by Dobbie, I9 Io.

Description in brief - Large, pinkish or purplish mauve, ehanging to lavender, waved. Description in detail - Standard opens purplish mauve I 86 (I), with edge of I 86 (2-3); wings open heliotrope I 88 (2); flower changes soon to Parma violet 200 (I); introducer says, "color is 20 I (I) but paler." Standard large, Spencer-waved; wings large, waved, partly open, long and broad. Flowers two to four, on strong stems of medium length. Moderately fragrant. Bloom free, continuous. Plant of tall, strong, vigorous growth. Seed small, mottled.

Remarks - A pure stock.

\section{MAUVE BEAUTY}

Originated by

Introduced by Box.

Donated by Box, 1912.

Description in detail - Color of standard purplish mauve I86 (2-3), with violet tint on back and toward base; wings bright violet $198(\mathbf{I}-2)$, often splashed darker. Flower large, waved form; standard large, often double, slightly waved; wings long and broad, spreading. Substance good. Flowers two to three, on medium to long, slender stems. Mloderately fragrant. Bloom profuse. Plant of tall, slender growth. Leaflets broad, pointed; tendrils green.

Comparison - Similar to Asta Ohn and Florence Nightingale.

\section{MAUVE SPENCER}

Donated by Burpee, for advance trial, i9ro.

Description in brief - A large, waved, mauve variety.

Description in detail - Color of standard varies from violet-mauve I95 (I) to lilac'mauve 196 (I); wings I96 (4). Standard very large, Spencer-waved; wings very 
large, waved, long and very broad. Flowers two to three, on long, strong stems.

Bloom profuse. An exhibition variety. Plant of tall, stout growth. Tendrils colored; color in axils of leaves.

Comparison - Would supplant Frank Dolby.

Remarks - Unfortunately not fixed.

\section{MRS. CHARLES FOSTER}

Originated by Bakers.

Introduced by Bakers, 1907 .

Donated by Dobbic, 1910.

Description in brief - Large, lavender flushed with rose, waved.

Description in detail - Color of standard purplish matve I 86 (2), back heliotrope I 88 (2-3); wings heliotrope $\mathbf{1} 88$ (2). Standard large, moderately waved; wings large, long and broad, partly open. Flowers two to three, on very long, strong stems. Fragrant. Bloom profuse. Plant of strong, tall growth. Germination poor.

Comparison - Here this variety was distinct this year from Frank Dolby, Masterpiece, and Asta Ohn.

Remarks - A fixed stock.

\section{MRS. REGINALD HILL}

Originated by

Introduced by King, 1913.

Donated by King, I913.

Description in brief - " A lilac lavender." - King's catalogue.

Description in detail - Color of standard bluish lilac, overlaid with violet 183 (1), deeper at base; wings vinous-mauve $\mathbf{1} 8+$ ( 1 or lighter), edged with bluish lilac. Flower of medium size, waved form; standard of medium size, slightly waved; wings short and broad, concealing the keel. Flowers two to three, equidistant, close, on medium stems. Not fragrant. Bloom profuse. Sunproof. Plant of tall, slender growth. Leaflets dark green, broad, pointed; tendrils green.

\section{MOONSTONE}

Originated by Aldersey.

Introduced by Aldersey, I9II.

Donated by Aldersey, 1912.

Description in brief - A pale heliotrope.

Description in detail - Color of standard lilae $187(2-3)$ to heliotrope at the base; wings heliotrope I88 (I-2). Flower large, waved form; standard large, often double, slightly waved; wings long and broad, spreading. Substance poor. Flowers two to three, irregularly spaced on slender stems of medium length. Fragrance moderate. Moderately productive. Plant tall, slender. Leaflets narrow, pointed; tendrils green.

Comparison - Similar to Nettie Jenkins.

\section{NETTIE JENKINS}

Originated by Unwin.

Introduced by Unwin, I91 I.

Donated by Unwin, for advance trial, 1910.

Description in brief - A large, waved, lavender, garden or exhibition variety.

Description in detail - Stanclard opens purplish mauve I86 (I), tinted faint blue; wings violet $200(3)$; flower loses the pinkish color, becoming a very light lavender 
$200(\mathbf{I}-3)$. Flowers two to three, on long, strong stems. Fragrant. Bloom profuse, continuous. Plant of medium height and strong, healthy growth. Seed dark brown, small, irregular or wrinkled.

Comparison - Belongs to the Frank Dolby group, but is quite distinct.

Remarks - A pure stock.

\section{ORCHID}

Originated by Malcolm.

Introduced by Burpee, I9I3.

Donated by Burpee, I9I2.

Description in brief - Large, waved, lavender suffused with pink.

Description in detail - Color of standard purplish mauve I86 (I or lighter), flushed with violet; wings heliotrope $\mathbf{1} 88$ (I or lighter). Flower large, waved form; standard large, slightly waved; wings short and broad, concealing the keel. Flowers three to four, equidistant, close, on medium stems. Very fragrant. Productive. Sunproof. Leaflets broad, round, dark green; tendrils green.

\section{PEARL GREY}

Originated by Morse.

Introduced by Burpee, Morse, I9I2.

Donated by Burpee, Boddington, I9I2.

Description in brief - "A dove grey suffused light rose."- Burpee's catalogue.

Description in detail - Color Parma violet $200(\mathrm{I}-2)$. Flower very large, waved form; standard very large, much waved; wings large, long and broad, spreading. Substance good. Flowers three, on long stems of moderate strength. Very fragrant. Bloom profuse. Plant of very tall, stout growth.

Comparison - Seems to be a paler form of Orchid.

Remarks - Variety not fixed in 1912 or in 1913.

\section{PRINCESS ALICE SPENCER}

Originated by Routzahn.

Introduced by Bath, I9o9.

Donated by Vick, I9IO.

Description in brief - Flower large. Described in catalogue as light lavender, tinted with white.

Description in detail - Standard large, slightly waved; wings large, hooded, long and broad; concealing the keel. Flowers two to three, nearly always three, on long, strong stems. Fragrant. Bloom profuse, continuous. A garden variety. Plant of medium height and strong, healthy growth. Seed small, mottled.

Remarks - Very unfixed, since it contains all shades of lavender with a few white flowers.

\section{QUEEN OF MAUVES}

Originated by Sutton.

Introduced by Sutton, I9I3.

Donated by Sutton, 1912.

Description in detail - Color of standard violet-mauve 195 (I), with more mauve on back; wings bluish violet 199 ( 1 or lighter). Flower large; standard slightly waved, with broad base; wings large, long and broad. Substance good. Flowers three, irregularly placed, but facing one way, on stems of medium length. Moderate fragrance. Bloom profuse. Sunproof. Plant of medium height, slender. Leaflets narrow, pointed; tendrils green.

Comparison - Has more lavender and shorter stems than Dorothy Tennant. 


\section{WALTER P. WRIGHT}

Originated by Unwin.

Introduced by Unwin, 1912.

Donated by Sydenlam, Unwin, I9I3.

Compariscn - Similar to Winifred Unwin (described below).

\section{WINIFRED UNWIN}

Originated by Unwin.

Introduced by Unwin, I9 2.

Donated by Unwin, I9I3.

Description in detail - Color of standard lavender-blue 204 ( 1 or lighter), with lighter color on back; wings same as standard. Flower large, waved form; standard large, slightly waved; wings short and broad, concealing the keel. Flowers three to four, irregularly spaced, close, on long, strong stems. Moderately fragrant. Bloom profuse. Sunproof. Plant of very tall, strong growth. Leaflets broad, rounded, dark green; tendrils green.

Comparison - Similar to Walter P. Wright, and both are similar to Dobbie's True Lavender, a variety approved by the National Sweet Pea Society of England.

\section{Magenta}

Originated by Dobbie.

\section{MARKS TEY}

Donated by Dobbie, 1912, 1913.

Description in brief - A large, bicolor variety, with rosy maroon standard and purpleviolet wings.

Description in detail - Color of standard reddish violet $180(\mathrm{I}-4)$; wings bright violetpurple $190(\mathrm{I}-2)$. Flower very large, often double, waved form; standard very large, slightly waved; wings large, long and broal. Flowers three, on strong stems of moderate length. Moderately fragrant. Moderately productive. Burns slightly. Plant of medium height, stout. Leaflets broad, pointed; tendrils green. Comparison - Slightly more red than Sutton's Royal Purple.

Remarks - This is placed in bicolor section in English lists. In general effect it belongs here.

Originated by Dobbie.

\section{MENIE CHRISTIE}

Donated by Dobbie, 1910; Rohnert, 1912; Burpee, 1913.

Description in brief - A large, waved, magenta variety.

Description in delail - Color of standard magenta $182(2-4)$, veined darker; wings magenta with a violet tinge, to violet-purple I,2 (I). Flower large, waved form; standard large, much waved; wings long and broad, spreading. Substance good. Flowers three, on slender stems of medium length. Very fragrant. Bloom profuse. Sunproof. Plant of tall, stout growth. Leaflets broad, pointed.

\section{PURPLE}

Originated by Malcolm.

Introduced by

Donated by Malcolm, Dobbie. 1912.

Description in brief - A large, waved, reddish violet and deep purple variety.

Description in detail - Color of standard reddish violet $180(3-4)$; wings deep purple I $85(\mathrm{I}-2)$. Flower large, waved form; standard large, often double, slightly 
waved; wings long and broad. Flowers two to four, on long, strong stems. Moderately fragrant. Morlerately productive. Wet weather injures flowers badly. Plant of melium height and stout growth. Leaflets broad, pointed.

Comparison-Similar to Marks Tey and Menie Christie, but not so large nor so profuse in bloom. Produced more doubles than either of the above.

\section{ROYAL PURPLE}

Originated by

Introduced by Sutton, I912.

Donated by Sutton, 1912.

Description in brief - A large, waved, purple variety.

Description in detail - Color of standard deep purple $185(2-3)$; wings bright violetpurple 190 (I). Flower large, waved form; standard large, slightly waved; wings long and broad, spreading. Flowers three, on long stems of medium strength. Very fragrant. Moderately produetive. Burns slightly. Plant of tall, slender growth. Leaflets broad, pointed; tendrils colored.

Comparison - Less red than Marks Tey.

\section{Marbled}

Originated by Dobbie.

Introduced by Dobbie, I9I2.

Donated by Dobbie, 1912, 1913.

Description in detail-Color marbled on standard is Tyrian rose $\mathbf{1 5 5}$ (I), on a creamy white Io (2) ground; wings slightly veined with the same color. Flower large, waved form; standard large, much waved; wings long and broad, spreading. Substance grod. Flowers three, on long, strong stems. Moderately fragrant. Moderately productive.

Comparison - Is larger than Aurora Spencer.

Remarks - A very distinct variety. One of the commended varieties of I9I2. Deserves a place on every list.

\section{SWEET LAVENDER}

Originated by Bath.

Introduced by Bath, 1910.

Donated by Bath, I9I0.

Description in brief - " White ground, marbled lavender, charming flower; fixed."Introducer's description.

Remarks - This variety proved to be of two shades of red in equal proportions.

\section{Maroon}

Originated by Alsen.

\section{ANNABEL LEE}

Donated by Alsen, I9I2.

Description in brief - "A pale lilac almost white in eenter." - Originator's description. Description in detail - Color of standard dull purple-lake 170 , with violet veining and shading at base; wings reddish violet I 80 (I-2). Flower large, waved form; standard large, much waved; wings large, long and broad, spreading. Flowers three, irregular on long, strong stems. Fragrance moderate. Productive. Burns badly. Plant of tall, strong, healthy growth. Leaflets broad.

Remarks - One cream-pink rogue. Apparently this did not give us the true-colored variety. 


\section{BRONZE PARADISE}

Originated by Miss Hemus.

Introduced by Miss Hemus, I9Io.

Donated by Miss Hemus, 1910.

Description in brief - A waved maroon self.

Description in detail - Color of standard deep purple I $85(4)$; wings I 8.5 (I). Flower of medium size; standard of medium size, generally flat; wings partly open, long and narrow. Flowers two to three, on long stems of fair strength. Growth moderate. Plants were not healthy.

Comparison - Differs from Paradise Maroon in having wings of the same color as the standard.

Remarks - A fixed variety as to color.

\section{CHARLES HEMUS}

Originated by Miss Hemus.

Introduced by Miss Hemus, I9I0.

Donated by Miss Hemus, 19 Io.

Description in brief - Originator described the variety as a red-mahogany self.

Description in detail - Color of standard amaranth-red $168(4)$; wings rosy magenta

I69 (I); keel colored a lighter shade. Flower large; standard large and slightly waved; wings long and narrow. Flowers two to three, on long stems of moderate strength. Fragrance moderate. Plant of medium height and slender growth. Foliage blue-green; calyx and pedicel blue-black. Seed dark brown, large, round. Comparison - Does not closely resemble Black Knight in color.

Remarks - A fixed stock. A distinct variety. Flowers turn darker with age.

\section{CYRIL UNWIN}

Originated by Unwin.

Introduced by Unwin, I912.

Donated by Unwin, 1913.

Description in brief - Deep purple shaded with maroon, waved.

Description in detail-Color of standard deep purple I 85 (I), shaded with maroon, base bright violet-purple; wings bright violet-purple I9I (I-2), varying to light pansy-violet. Flower large, waved form; standard large, much waved; wings short and broad, concealing the keel. Flowers three to four, irregularly spaced on long, strong stems. Moderately fragrant. Bloom moderate. Sunproof. Plant of tall, strong growth. Leaflets broad, round, dark green; tendrils green.

\section{DOUGLAS UNWIN}

Originated by Unwin.

Introduced by Unwin, I9I0.

Donated by Unwin, I910.

Description in brief - A large, waved variety.

Description in detail - Color plum-violet 172 (4). Standard large, slightly waved; wings waved, concealing the keel. Flowers thrce, on strong stems of medium length. Fragrance moderate. Plant moderately vigorous. Leaves narrow, pointed. Seed black.

Comparison - Similar to Uthello Spencer, but not so good a strain.

Remarks - Stock mixed. 


\section{GARNET SPENCER}

Originated by

Introduced by Henderson, igio.

Donated by Henderson, I9Iò.

Description in brief - A very large, maroon, waved variety, fine for exhibition.

Description in detail - Color of standard plum-violet I72 (I-2); wings deep carmineviolet $\mathbf{I} 7+(\mathbf{I}-2)$. Standard very large, much waved; wings very long and broad, waved, concealing the keel. Flowers three, on long, strong stems. Moderately fragrant. Bloom profuse, continuous, lasts well on plant. Sunproof. Plant of tall. stout, healthy growth.

Comparison - A fine strain of Othello Spencer, but unfixed.

Remarks - Very much mixed, containing five varieties of waved form.

\section{KING MANOEL}

Originated by Stark.

Introduced by Stark, I912.

Donated by Stark, I9I2.

Description in brief - A large, waved, dark maroon variety.

Description in detail - Color of standard plum-violet 172 (I), veined darker; wings deep purple I85 (3-4). Flower very large, waved form; standard very large, slightly waved; wings very large, long and broad, spreading. Substance good. Flowers three, close together on long, strong stems. Moderately fragrant. Moderately productive. Sumproof. Plant of tall, strong growth. Leaflets broad, pointed; tendrils green.

Comparison - Has larger flowers and is of better growth than Othello Spencer.

\section{NUBIAN}

Originated by House.

- Introduced by House, I9I I.

Donated by Burpee, I9I3.

Description in brief - A deep maroon self.

Description in detail - Color of standard between purple-brown r66 and deep carmineviolet I74 (4 or darker); wings deep carmine-violet I74 (2-3). Flower large, waved form; standard large, slightly waved; wings short and broad. Flowers three, equidistant, close, on long, strong stems. Moderate fragrance. Bloom profuse. Sunproof. A garden, market, or exhibition variety. Plant of tall, slender growth. Leaffets broad, round, dark green.

Synonyms - King Manoel is practically the same.

Remarks - The best of this color group. Stock pure, true.

\section{OTHELLO SPENCER}

Originated by Morse.

Introduced by Burpee, Morse, I909.

Donated by Burpee, Morse, i9io.

Description in brief - A very large, very waved, maroon variety, excellent for garden or exhibition use.

Description in detail - Color of standard plum-violet I72 (4); wings deep purple I85 (I-2); flower has almost black veins. Standard very large, decidedly and uniformly waved; wings waved, very long and broad. Flowers three, on long, strong stems. Fragrance slight or none. Bloom profuse, continuous. Plant of tall, strong growth. Seed large, round, few in number. 
Comparison-Long the stindard maroon waved viriety, but now surpassed by Nubian ancl King Manoel.

Remarks - Both stocks fixerl.

\section{PRINCE OF ASTURIAS}

Originated by Breatmore.

Introduced by Breadmore, 1908 .

Donated by Rawson, I9I0.

Description in brief - $\Lambda$ large, waved, maroon, garden variety.

Description in detail - Color of standard plum-violet $172(4)$; wings 172 (2-3). Standard large, waved; wings large, hooded, concealing the keel. Flowers two to three, on fair stems. Fragrant. Bloom free. Plant of moderately vigorous growth.

Comparison - Inferior to Othello Spencer.

Remarks - Stock mixed.

\section{SILAS COLE}

Originated by Cole.

Introduced by Cole, 19 ro.

Donated by Cole, igro.

Description in brief - A large, deep maroon, waved variety.

Description in detail - Color of standard rich pansy-violet 19I (3-4); wings deep purple 185 (I). Standard medium to large, generally not waved; wings long and narrow, concealing the keel. Flowers two to four, on long stems. Bloom profuse. Plant of moderately tall, healthy growth. Calyx and pedicel blueblack.

Comparison - Resembles Black Knight in color.

Remarks - Contained one rogue. Did not attain to Spencer size or form.

\section{VICTOR UNWIN}

Originated by Unwin.

Intrcduced by Unwin, I9I3.

Donated by Unwin, 1913.

Description in brief - " Rich deep chocolate or mahogany colored self, free from any trait of purple." - Unwin's catalogue.

Description in detail - Color of standard plum-violet $\mathbf{1 7 2}(3-4)$, tinged with violet; wings deep carmine-violet $17+(3-4)$. Flower large, waved form; standard large, waved; wings short and broad, concealing the keel. Flowers two to three, on short stems. Moderately fragrant. Moderately productive. Sunproof. Plant of medium height and slender, healthy growth. Leaflets broad, pointed, dark green.

\section{Maroon-Purple}

Originated by Dobbie.

Introduced by Dobbie, I911.

Donated by Boddington, 1911; Burpec, Dobbic, Morse, 1912; Burpee, 1913.

Description in brief - Standard carmine-violet; wings deep purple.

Description in detail - Color of standard deep carmine-violet $174(3-4)$, veined darker; wings deep purple $185(2-3)$, sometimes with slight tints and markings of violetpurple. Flower very large, waved form; standard very large, waved; wings long and broad, spreading but drooping. Flowers three to four, irregular on strong stems of medium length. Fragrance moderate. Moderately productive. Plant of tall, strong growth. Leaflets broad, pointed, dark green; tendrils green. 


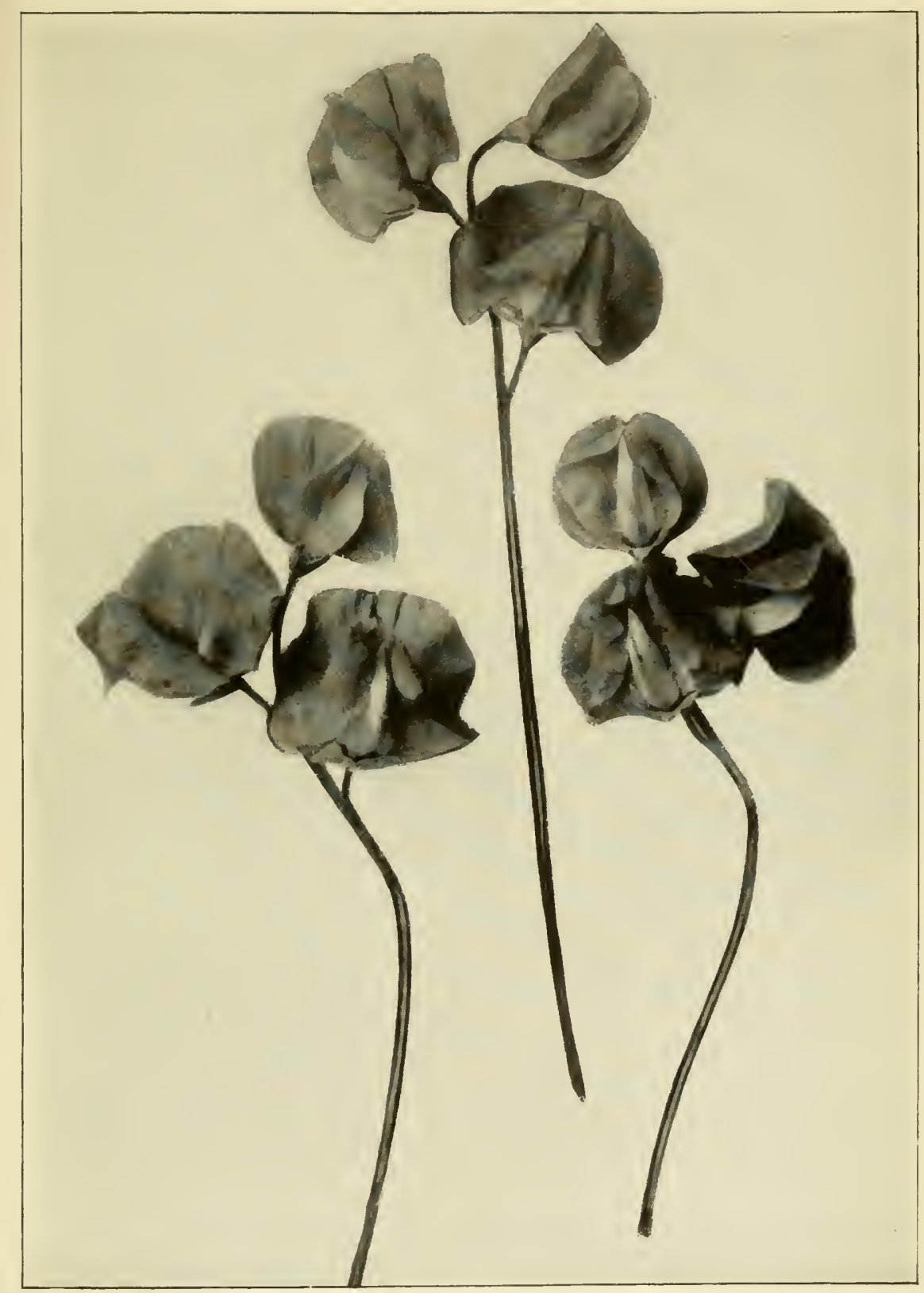

Othello Spencer 


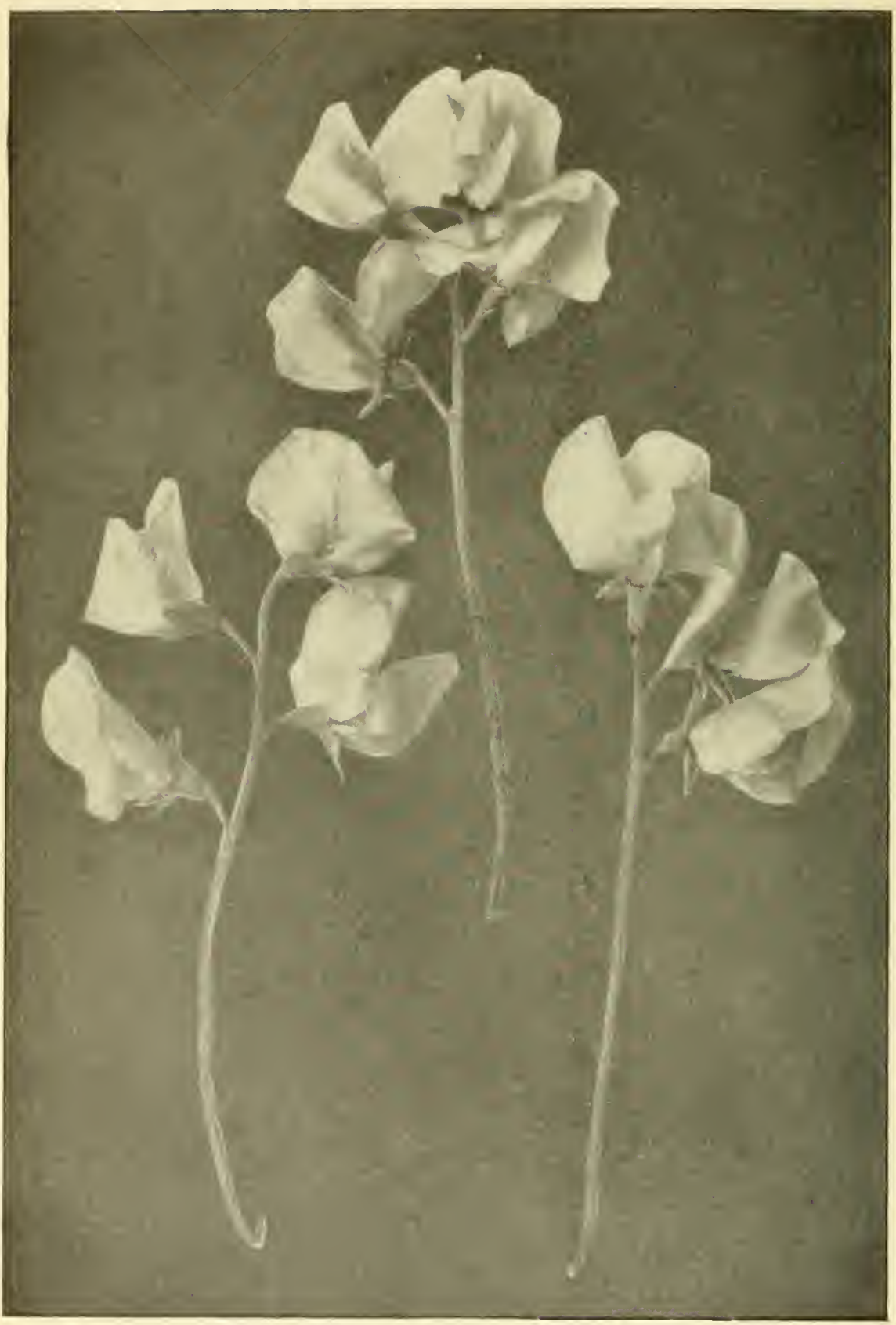

Tennant Spencer 


\section{CAPTAIN OF THE BLUES SPENCER}

Originated by Morse.

Introduced by Morse, I909.

Donated by Morse, I910; Burpee, I9II.

Description in brief - A very large, waved variety, with bright purple standard and blue wings. Excellent for garden or exhibition.

Description in detail - Color of standard reddish violet 180 (4); wings bishop's violet I 89 (3). Standard very large, much waved; wings large, waved, long and broad. Flowers two to four, on long, strong stems. Fragrant. Bloom profuse, continuous, lasts well on the plants. Sunproof. Plant of tall, stout, healthy growth.

Remarks - Not fixed. Not correctly named, since it does not resemble Captain of the Blues in color. One of the largest-flowered varieties.

\section{JOHN RIDD}

Originated by Stark.

Introduced by Stark, 1912.

Donated by Stark, 1912; Boddington, 1913.

Description in brief - "A large, waved, purple self." - Sweet Peas Up to Date.

Description in detail-Color of standard plum-violet 172 (4); wings vinous-mauve

I $8+$ (4). Flower large, waved form; standard large, waved, slightly auriculate; wings large, long and broad, spreading. Substance good. Flowers three to four, on long, strong stems. Very fragrant. Bloom scant to medium. Plant of tall, strong growth. Leaflets broad, pointed; tendrils green.

Remarks - Stock pure, true.

\section{MAROON PARADISE}

Originated by Miss Hemus.

Introduced by Miss Hemus, I909.

Donated by Miss Hemus, I9ro.

Description in brief _ " Deep maroon, waved." - Sweet Pea Annual.

Description in detail - Color of standard deep purple I $85(2-3)$; wings bishop's violet I $89(2-3)$; reverse bright violet-purple igo (4). Flower large, waved form; standard large, Spencer-waved; wings long and broad, spreading. Flowers three, equidistant on long stems. Bloom profuse. Sunproof. Plant of medium height and stout, healthy growth. Leaflets narrow, pointed; color in axils of leaves and leaflets; tendrils colored.

Comparison - At this station in I9Io this variety was distinct from Black Knight.

\section{MRS. E. COWDY}

Originated by Bolton.

Introduced by Bolton, 1913.

Donated by Boddington, I913.

Description in detail - Color of standard plum-violet I $72(3-4)$; wings deep purple $185(2-3)$, veined with plum-violet. Flower large, waved form; standard large, waved; wings short and broad, concealing the keel. Flowers three, equidistant, close, on medium stems. No fragrance. Moderately productive. Sunproof. Plant of tall, slender growth. Leaflets broad, pointed, dark green. Comparison - Similar to John Ricld, perhaps a less deep purple. Remarks - Stock pure, true. 


\section{PURPLE PRINCE SPENCER}

Originated by Dickson.

Intrcduced by Burpee, 1911.

Donated by Burpee, 19II.

Description in brief - "Standard purplish maroon, wings rosy purple." - Sweet Peas Up to Dite.

Description in detail - Color of standard deep purple I85 (3); wings bishop's violet

I \&9 (4). Flower very large, waved form; standard large, waved; wings large,

long and broad. Flowers borne on long, strong stems. Plant of tall, strong, vigorous growth.

Comparison - This is almost a self and therefore differs from Captain of the Blues

Spencer. In this respect it is an improvement.

Remarks - This is not the color of the old variety Purple Prince.

\section{WAVERLY SPENCER}

Originated by Morse.

Introduced by Morse, 1909.

Donuted by Burpee, I9I.

Description in brief - " Purplish maroon, wings rosy purple." - Sweet Peas Up to Date. Comparison - Similar to Captain of the Blues Spencer, but smaller.

Remurks - Only one plant appeared to resemble the old Waverly in color.

\section{Maroon-Red}

Originated by Dobbie.

Introduced by Dobbie, 1913.

Donated by Dobbie, 1913.

Description in brief - A large, waved, rich deep mahogany sclf.

Description in detail-Color of standard and wings plum-violet 172 ( 4 or darker).

Flower Iarge, waved form; standard large, much waved; wings large, concealing

the keel. Flowers two to three, on medium stems of short length. No fragrance.

Bloom profuse. Burns slightly. Plant of medium height and slender growth.

L.eaflets narrow, pointerl, dark green; tendrils green.

Remarks - An excellent variety. Stock pure, true.

\section{RED CHIEF}

Originated by Bolton.

Introduced by Bolton, 9 IO.

Donuted by Sydenham, I9I3.

Description in detail - Color of standard plum-violet 172 ( 4 or darker); wings plumviolet $1 / 2(1-2)$. Flower large, waved form; standard large, waverl; wings long and broad, concealing the kecl. Flowers three, on strong stems of medium length. Moderitely fragrant. Moderately productive. Surproof. Plant of tall, slender growtl. Leaflets broad, round, dark green.

Remarks - With Brunette the leader of its class.

Mauve

\section{A. J. $\mathrm{COOK}$}

Originated by Unwin.

Introduced by Unwin, and Watkins \& Simpson, 1907.

Donated by Ratwson, Unwin, and Watkins \& Simpson, I910.

Description in brief $-\Lambda$ moderately large, violet-mauve variety, of Unwin form. 
Description in detail - Standard opens violet-mauve I95 (I), changing to I95 (4); wings tinted with more violet, which becomes deeper, toward bright violet-purple 190 (I). Standard medium to large, Unwin type; wings long and broad, concealing the keel. Flowers two to three, on long, strong stems. Fragrant. Bloom profuse, continuous. A garden or market variety. Plant of medium height and stout, healthy growth. Seed small, mottled.

Remarks - A distinct and worthy variety. One stock pure; rogues mostly Othello.

\section{AMETHYST}

Originated by Aldersey.

Introduced by Aldersey, I9I I.

Donated by Aldersey, I912.

Description in detail - Color of standard pure mauve I8I (3-4), shading to bright violet at base; wings bright violet 198 (I), sometimes with a rosy tinge. Flower large, waved form; standard large, slightly waved; wings long and broad, spreading. Moderate fragrance. Moderately productive. Plant of tall, slender growth. Leaflets broad, pointed; tendrils green.

Comparison - Similar to Royalty.

\section{BERTHA MASSEY}

Originated by Bide.

Introduced by Bide, I9I2.

Donated by Boddington, 1912, 1913.

Description in brief - A large, waved, lilac-mauve variety.

Description in detail - Color of standard pure mauve $18 \mathrm{I}(\mathrm{I}-2)$; wings bright violet I98 (I-2), edged with purplish mauve. Flower large, waved form; standard large, slightly waved; wings long and broad, concealing the keel. Flowers three, equidistant, close, on medium stems. Moderate fragrance. Productive. Sunproof. Plant of medium height and slender growth.

Comparison - Surpassed by Frances Deal.

Remarks - Stock pure in I912, mixed in I913.

\section{BETTY}

Originated by Dobbie.

Introduced by Dobbie, I9I 2.

Donated by Dobbie, I9I2.

Description in brief - A purplish mauve variety.

Description in detail - Color of standard pure mauve $18 \mathrm{I}$ (I), shading often to purplish mauve I 86 (I); wings purplish mauve. Flower very large, waved form; standard very large, much waved, slightly auriculate; wings very large, long and broad. Flowers three, equidistant on long stems of medium strength. Moderately fragrant. Bloom moderate. Sunproof. Plants of tall, slender, healthy growth. Leaflets broad, pointed; tendrils colored.

Comparison - Has paler and larger flowers than Tennant Spencer.

\section{EMILY ECKFORD SPENCER}

Originated by

Introduced by Burpee, I $\dot{\text { II }}$.

Donated by Burpee, for advance trial, I9I0.

Description in brief - A large, mauve, Spencer variety.

Description in detail - Standard opens bluish lilac 183 (I), changing to bright violet 198 (I); wings heliotrope 188 (3), changing to bright violet I98 (2). Standard large, slightly waved; wings partly open, long and broad. Flowers two to three. 
Fragrant. Bloom profuse. A garlen, market, or exhibition variety. Plant of medium height and stout, healthy growth. Color in axils of leaves. Seed mottled. Comparison - Distinct in color from The Marquis.

Remarks - A fixed stock.

\section{EMPRESS}

Originated by Deal.

Introduced by Deal, I9II.

Donated by Deal, I912.

Descripticn in brief - A rich purple-mauve.

Description in detail - Color of standard reddish violet 180 (I); wings deep purple I 85 (I). Flower very large, waved form; standard very large, waved, sometimes double; wings very large, long and broad, spreading. Flowers two to three, on medium stems. Very fragrant. Productive. Sunproof. Plant of tall, strong growth. Leaflets broad.

Comparison - Has less red in standard, but otherwise is similar to Annabel Lee.

Remarks - Color rogues: (1) pure cream, (2) pale rosy pink.

\section{FRANCES DEAL}

Originated by Deal.

Introduced by Deal, 1912.

Donated by Deal, 1912.

Description in brief - "A rosy heliotrope." - Sweet Peas Up to Date.

Description in detail - Color of standard and wings reddish violet I80 (I), with a light spot at base of standard. Flower very large, waved form; standard very large, much waved; wings large, long and broad, spreading. Flowers two to three, irregularly placed, usually far apart, on long, strong stems. Moclerate fragrance. Bloom profuse. Sunproof. Plant of tall, strong, healthy growth. Leaflets broatel, pointed; tendrils colored.

Comparison - Superior to Bertha Massey.

\section{HELIO PARADISE}

Originated by Miss Hemus.

Introduced by Miss Hemus, 1910.

Donated by Miss Hemus, 1910.

Description in brief - Large, pale rosy heliotrope, waved.

Description in detail-Color of standard purplish mauve $186(\mathbf{I}-2)$, deepest at base; wings bishop's violet 189 (2). Standard large, Spencer-waved; wings large, waved, long and broad. Flowers two to three, on long, strong stems. Mloderately fragrant. Bloom profuse. Sumproof. Plant of medium height and moderately strong growth. Tendrils colored; color in axils of leaves. Seed mottled.

Comparison - Similar to The Marquis, but not superior.

Remarks - A fixed stock.

\section{HELIOTROPE SPENCER}

Originated by .

Introduced by Henderson, 1910.

Donated by llenderson, I) Io.

Description in brief - Large, hooled, deep purple-mature.

Description in detail - Color of standard bishop's violet Is9 (1-2); wings I89 ( $1-3)$.

Stindard large, hooded; wings large, long and broad, concealing the keel. Flowers 
two, on long, strong stems. Very fragrant. Bloom profuse, continuous. Plant of medium height and strong, healthy growth. Color in axils of leaves. Seed mottled, large.

Comparison - Color similar to Mrs. Walter Wright.

Remarks - A pure stock. Flowers did not take Spencer form.

\section{MAUVE PARADISE}

Originated by Miss Hemus.

Introduced by Miss Hemus, I9Io.

Donated by Miss Hemus, 1910.

Description in brief - A medium-sized, mauve variety.

Description in detail - Color of standard bluish lilac 183 (1); wings 183 (1-2). Standard of medium size; wings large, long and narrow, spreading. Flowers two to three. Moderate fragrance. Bloom medium. Burns slightly. Plant of medium height and stout, healthy growth. Seed mottled.

Comparison - Wings always paler than those of The Marquis or Tennant Spencer.

Remarks - Introducer stated that the stock might give some Primrose Paradise sports.

This occurred in the tests at this station.

Originated by Dobbie.

\section{MAUVE QUEEN}

Donated by Dobbie, I912.

Description in brief - A large, waved, mauve variety.

Description in detail - Color of standard purplish mauve I86 (I), shading toward violet-1nauve 195 (I) in center; wings violet-mauve 195 (I). Flower very large, waved form; standard very large, slightly waved, with slightly auriculate base; wings very large, long and broad. Substance good. Flowers three, equidistant on medium stems. Very fragrant. Bloom profuse. Sunproof. Plant of medium height and slender, healthy growth. Leaflets broad, pointed; tendrils green.

Comparison - Similar to Winsome, but a trifle more purple.

\section{MRS. HESLINGTON}

Originated by W. S. Heslington.

Introduced by Dobbie, 1912.

Donated by Dobbie.

Description in detail-Color of standard purplish mauve 186 (1-2), shading to bright violet 198 (I-2) in the center; wings bright violet $198(\mathrm{I}-2)$. Flower very large, waved form; standard very large, often double, much waved, with auriculate base; wings long and broad. Substance good. Flowers three, equidistant on long stems of medium strength. Moderate fragrance. Bloom profuse. Sunproof. Plant of tall, slender, healthy growth. Leaflets broad, pointed; tendrils green.

Comparison - Very similar to Mauve Queen, but differs in form of flower and in color of wings. More mauve than Florence Nightingale.

\section{ROYALTY}

Originated by Bath.

Introduced by

Donated by Bath, I912.

Description in detail - Color of standard reddish violet 180 (I); wings bright violetpurple 190 (I). Flower of medium size, waved form; standard of medium size, 
slightly waved; wings of melium size, drooping. Flowers three, on medium stems. Molerate fragrance. Bloom profuse.

Comparison - Much like Dobbie's Violet Flush.

Remarks - Of no special merit at this station.

\section{TENNANT SPENCER}

Originated by Morse.

Introduced by Morse, I909.

Donated by Morse, 1910; Burpec, I911.

Description in brief - Large, waved, purple-mauve self.

Description in detuil - Color of stindard purplish mauve $196(2-3)$; wings 186 (1-2) on the inside, $186(2-3)$ on the outside. Standard large, waved; wings waved, long and broad, concealing the keel. Flowers two to four, often four, on strong stens of melium length. Very fragrant. Bloom profuse, continuous. Plant of medium height and moderately strong growth. Tendrils colored; color in axils of leaves. Seed mottled.

\section{THE MARQUIS}

Originated by Dobbie.

Introduced by Dobbie, I908.

Donated by Dobbie, 1910.

Descriplion in brief - A large, purplish mauve, waved variety.

Description in detail - Color of standard purplish mauve I86 (4); wings bishop's violet I $89(4)$; the standard showing more red and the wings more blue. Standard large, wəved; wings very large, waved, long and broad, concealing the keel. Flowers two to three, on long, strong stems. Fragrant. Bloom profuse. A garden, market, or exhibition flower. Plant of melium height and moderately strong growth. Seed mottled, wrinkled.

Remarks - The 1910 stock was mixed and contained one Gladys Unwin.

\section{Orange-Pink}

\section{CARENE}

Originaied by

Introduced by Watkins \& Simpson, I9I2.

Donated by Boddington, 1912, 1913.

Description in brief $-\Lambda$ large, deep orange-pink variety.

Description in detail - Color of standard salmon-pirk $126(3-4)$, veined slightly darker; wings 126 (4), shading into purple-rose $15^{\circ}(3-4)$ at base. Flower very large, waved form; standard very large, waved; wings very large, long and broad, open. Flowers two to three, equidistant on long, strong stems. Very fragrant. Bloom profusc. Plant of tall, slender growth. Leaflets broad, pointed; tendrils green.

Comparison - Is of stronger growth, has better flower stems and slightly larger flowers with more red in the wings, and exhibits less burning, than Stirling Stent.

\section{EDITH TAYLOR}

Originated by Holmes.

Introduced by Holmes, Sydenham, 1912.

Donated by Syclenham, 1912, 1913.

Description in brief - "A waved salmon-rose self." - Sweet Peas Up to Date.

Description in detail - Color of standard and wings cerise 123 (I-2); standard veined darker. Flower very large, waved form; standard slightly waved, very large; 
wings large, long and broad, spreading. Flowers three, on long, stout stems. Fragrance almost none. Burns slightly. Wet weather injures slightly. Plant of medium height and slender growth. Leaflets broad, pointed.

Comparison - A little less orange than Helen Lewis.

\section{EDROM BEAUTY}

Originated by Malcolm.

Introduced by Dobbie, I9II.

Donated by Dobbie, 1912, 1913.

Description in brief - Standard orange, wings rosy salmon.

Description in detail - Color of standard salmon-pink 126 (2), with darker veins; wings purple-rose I50 (2). Flower very large, waved form; standard very large, Spencer-waved, sometimes double: wings large, long and broad. Flowers on long, strong stems. Bloom moderately productive, does not last well on the plant. Burns badly. Suffers slightly in wet weather. Plant of tall, strong growth. Leaflets broad, round; tendrils green.

\section{GLYN TURQUAND}

Originated by Alsen.

Introduced by

Donated by Alsen, I912.

Description in brief - Rich crimson-scarlet, with a suggestion of orange.

Description in detail - Color of standard and wings carmine-lake 121 ( $1-2)$, veined

slightly darker. Flower large, waved form; standard large, slightly waved; wings long and broad, spreading. Flowers three, on strong, very long stems. No fragrance. Moderately productive. Burns slightly. Plant of tall, strong growth.

Leaflets broad, pointed; tendrils green; foliage rich dark green. Comparison - An improved Helen Lewis.

\section{HELEN GROSVENOR}

Originated by Aldersey.

Introduced by Aldersey, I9I0.

Donated by Sydenham, I912.

Description in brief - A deep orange-salmon.

Description in detail - Color of standard madder lake 122 (1-2), shading to deep rose-pink at the base; wings deep rose-pink $120(2-3)$, delicately veined with darker color. Flower large, waved form; standard large, slightly waved, sometimes double; wings long and broad, spreading. Flowers two to four, irregularly arranged on long, strong stems. Moderately fragrant. Moderately productive. Burns slightly. Is somewhat injured by wet weather. Plant of tall, strong growth. Comparison - Closely resembles Helen Lewis. Possibly a deeper color.

\section{HELEN LEWIS}

Originated by J. Watson.

Introduced by Breadmore, 1905.

Donated by Boddington, Dobbie, Morse, Unwin, I9I0.

Description in brief - Large, waved, rosy scarlet and cerise. Popularly known as orange. Suitable for all purposes.

Description in detail - Color of standard bright rosy scarlet 124 (2-3); wings deep cerise I23 (I). Standard large, Spencer-waved; wings large, waved, long and broad, concealing the keel. Flowers two to four, on long, strong stems. Moderately fragrant. Plant of medium, stout, healthy giowth. Seed biack, large, round. 
Synonyms - Orange Countess (Sydenham, 1905) and Mrs. Sydenham (Burpee, 1905). Remarks - Of the four stocks received in 1910 , two exhibited rogues.

\section{LAURA WYATT}

Originated by Dipnall.

Introduced by Dipnall, 1913.

Donated by Dipnall, I912.

Description in detail - Color of standard salmon-pink 74 (I), with carmine veining; wings carmine-lake I 2 I ( I-2). Flower large, waved form; standard large, slightly waved, sometimes double; wings long and narrow, spreading. Flowers two to three, on medium stems. Fragrance little or none. Moderately productive. Burns badly. Plant of tall, strong growth.

\section{LORD ALTHORP}

Originated by Cole.

Introduced by Cole, 1910.

Donated by Cole, I 910.

Descriplion in brief - Large, waved, orange-pink.

Description in detail - Color of standard bright rosy scarlet $124(2-3)$; wings deep cerise I $23(3-t)$.

Comparison - A fine strain of Helen Lewis, but does not stand the sun so well.

Remarks - A pure stock.

\section{ORANGE SPENCER}

Originated by

Intraduced by Henderson, I9I0.

Donated by Henderson, I910.

Description in brief - A large, orange, Spencer variety.

Description in detail - Color of standard rosy scarlet $12+(2-3)$; wings cerise $123(2-3)$. Comparison - Similar in color to Miss Wilmott Improved.

Remarks - A pure stock.

Originated by Bide.

\section{PHOEBUS}

Donated by Bide.

Description in detail - Color of standard Lincoln red 88 (I), veined darker; wings geranium red I I (lighter than i). Flower large, waved form; standard large, much waved, with broad base; wings large, long and broad, spreading. Flowers three, on slender stems of medium length. Moderate fragrance. Bloom profuse. Plant of medium height and slender growth. Leaflets broad, pointed; tendrils green.

\section{PRINCE OF ORANGE}

Originated by Miss Hemus.

Introduced by Miss Hemus, I9I0.

Donated by Miss Hemus, 1910.

Description in brief - Originator describes this as a large, waved, very vigorous, orange variety.

Remarks - Very unfixed. Was one half Countess Spencer, or Paradise, and one half John Ingman. No orange in it. The later selection has not been tested at this station. 


\section{Orange-Scarlet}

\section{ANDREW AITKEN}

Originated by Bolton.

Introduced by Bolton, 1913.

Donated by Boddington, 1913.

Description in brief - " A soft salmon-colored variety." - Bolton's catalogue.

Description in detail - Color of standard salmon-pink I 26 (2-3), flushed with Rose

Neyron red at base; wings rosy pink i 8 (2-3), flushed with Rose Neyron red.

Flower large, waved form; standard large, waved; wings large, long and broad, concealing the keel. Flowers three, equidistant, close, on medium stems. Moderately fragrant. Moderately productive. Burns slightly. Plant of medium height and slender growth. Leaflets broad, round, dark green.

Remarks - Stock pure, true.

\section{ANGLIAN ORANGE}

Originated by King.

Introduced by King, I9I I.

Donated by King, r913.

Description in brief - A large, waved, salmon-pink variety.

Description in detail - Color of standard bright rosy scarlet 124 (I), tinged with purplerose on the edge and at the base; wings purple-rose I5O (I or lighter). Flower large, waved form; standard large, slightly waved; wings large, concealing the keel. Flowers three, equidistant; close, on medium stems. No fragrance. Bloom profuse. Burns somewhat. Plant of medium height and strong growth. Leaflets broad, round, dark green.

Remarks - Contained two color rogues.

\section{DAZZLER}

Originated by Breadmore.

Introduced by Breadmore, 1910.

Donated by Farquhar.

Description in brief - " Bright flame color." - Sweet Pea Annual.

Description in detail - Color of standard and wings salmon-pink 126 (2-3). Flower large, waved form; standard large, slightly waved; wings short and broad, concealing the keel. Flowers three, on medium stems. No fragrance. Bloom medium. Burns slightly. Plant of tall, slender growth. Leaflets broad, round, dark green.

Comparison - Similar to Andrew Aitken.

Remarks - Stock pure, true.

\section{EDNA UNWIN IMPROVED}

Originated by Unwin.

Introduced by Unwin, I9I0.

Donated by Unwin, I9I0.

Description in brief - A medium-sized, slightly waved variety.

Description in detail - Color of standard rosy scarlet 124 (4); wings cerise $123(2-3)$.

Standard medium to large, slightly waved; wings moderately long and broad, partly open. Flowers two to three, on strong stems of moderate length. Fragrance slight. Bloom free. Burns slightly. Plant of tall, stout, healthy growth. Seed dark brown.

Comparison - Similar to St. George, but slightly superior in form.

Remarks - A pure stock. 


\section{ORANGE KING}

Originated by Bide.

Introduced by Bide, I9II.

Donated by Bide, 1910.

Description in brief - This variety is said to be a true orange self.

Comparison - The orange-colored flowers were similar to Edna Unwin Improved or St. George.

Remarks - A very unfixed stock. One plant Henry Eckford. Mostly pink-flowered plants.

\section{ORANGE PERFECTION}

Originated by Box.

Introduced by Box, I9I2.

Dcnated by Box, r912.

Description in brief - Standard orange, wings rose.

Description in detail - Color of standard shrimp pink 75 (I); wings deep rose-pink $120(1-2)$. Flower large, waved form; standlard large, slightly waved; wings large, long and broad, spreading. Flowers two to three, on slender stems of medium length. No fragrance. Bloom scant. Burns slightly. Plant of medium, very slender growth. Leaflets broad, pointed.

Comparison - Smaller, of paler color and poorer bloom, and a weaker plant than Thomas Stevenson in the trials at this station in 1912.

\section{RUBY}

Originated by

Introduced by Aldersey, I9io.

Donated by Aldersey, Marsden Jones.

Description in brief - "Standard bright orange scarlet; wings deep rose." - Introducer's description.

Description in detail - Color of standard coral-red $76(1-2)$, veined darker; wings carthamus red 88 (1), sometimes veined darker. Flower medium to large, slightly waved form; standard medium large, slightly waved; wings long and broad, spreading. Flowers two to three, on rather weak, short stems. Fragrance very little or none. Burns badly. Is badly injured by wet weather. Plant of moderately tall, slencler growth. Leaflets broad, pointed.

Comparison - Similar to Thomas Stevenson in color, but was the poorest of the orange group.

\section{ST. GEORGE}

Originated by

Introduced by Hurst, 1908.

Donated by Boddington, Dobbie, I9 Io.

Description in brief - A medium-sized garden variety.

Description in detail - Color of standard bright rosy scarlet $12+(3-4)$; wings deep rose-pink $120(2-3)$. Standard of medium size, some very slightly waved; wings moderately long and broad, concealing the keel. Flowers two to three, generally two, on short stems. Fragrance very slight. Bloom free. Burns badly. Plant of medium height and stout growth. Seed black, irregular in shape.

Comparison - Wings are not the same color as the standard, neither are they the color of the wings of Orange Spencer or Miss Wilmott Improved. 


\section{THOMAS STEVENSON}

Originated by Holmes.

Introduced by Sydenham, 19II.

Donated by Boddington, Burpee, Dobbie, Sydenham, I912; Burpee, Dobbie, Sydenham, 1913.

Description in brief - A rich orange-scarlet.

Description in detail - Color of standard madder lake I22 (2-3), veined darker; wings carmine-lake I 2 I (2-3), veined darker. Flower very large, waved form; standard very large, slightly waved; wings large, long and broad, spreading. Flowers on long, strong stems. Moderately fragrant. Moderately productive. Burns slightly. Plant tall, stout. Leafiets broad, pointed; tendrils green.

Comparison - Plant is of stronger growth, and produces larger flowers on longer stems, than Stirling Stent.

Remarks - The leading variety in this group.

Picotee Edged (Cream ground)

\section{EVELYN HEMUS}

Originated by Miss Hemus.

Introduced by Miss Hemus, I 908 .

Donated by Miss Hemus, I9I0.

Description in brief - Large, waved, picotee-edged pink on a primrose ground, for garden, market, or exhibition use.

Description in detail - Color of standard picotee-edged pale rosy pink 129 (1), on a fleshy white 9 (3) ground; wings 9 (2-3). Standard large, Spencer-waved; wings waved, long and broad. Flowers two to four, on long, strong stems. Fragrant. Bloom profuse, continuous. Plant of medium height and stout, healthy growth. Comparison - Closely resembles Mrs. C. W. Breadmore.

Remarks - A pure stock.

\section{HELEN WILLIAMS}

Orizinated by Stark.

Introduced by Stark, 1913.

Donated by Stark, 1912.

Description in brief - A large, waved, picotee variety.

Description in detail - Color yellowish white I3 (I), edged with purple-rose 150 (I), deeper on back; wings yellowish white I3 (I). Flower very large, waved form; standard very large, much waved; wings large, long and broad. Flowers three to four, wide apart on very long, strong stems. Moderately fragrant. Bloom medium. Plant of strong, vigorous growth. Foliage dark green; color in axils of peduncles and leaflets.

Comparison - Better than Mrs. Breadmore in I912. Not tested in 1913.

\section{MRS. C. W. BREADMORE}

Originated by Breadmore.

Introduced by Breadmore, 1908.

Donated by Boddington, Stark, Dobbie, 1910; Burpee, 1911 ; Rohnert, 1912.

Description in brief - Large, waved, picotee-edged pink on a primrose ground.

Description in detail - Color of standard picotee-edged pale lilac-rose $\mathrm{r} 30$ ( 1 ), on an amber-white 12 (I) ground; wings I 2 (I). Standard large, Spencer-waved; wings 
wavel, long and broad. Flowers two to three, on long, strong stems. Fragrant. Bloon profuse, continuous. Sunproof. Plant of medium height and stout, healthy growth.

Comparison - Closely resembles Evelyn Hemus.

Remarks - A pure stock.

Picotee Edged (White ground)

Originated by Bath.

\section{CHASTITY}

Donated by Bath.

Description in brief - Large, waved, pure white, with a blush edge.

Description in detail - Color of standard on opening shows faint primrose, later tinted violet-rose $15+$ (I); wings similar, but becoming a deeper tint. Flower very large, waved form; standard very large, slightly waved, many doubles; wings large, long and broad, drooping. Substance good. Flowers three, irregularly spaced on long, strong stems. Moderately fragrant. Productive. Plant of very tall, strong growth. Leaflets long, broad; tendrils colored.

\section{DAINTY SPENCER}

Originated by

Introduced by Burpee, I9I I.

Donated by Burpee, for advance trial, igro.

Description in brief - Large, waved, picotec-edged pink on a white ground.

Description in detail - Color of flower rosy white 8 (2) ground, with edge of standard Rose Neyron red II9 (I); edge of wings II9 (2). Standard large, very slightly waved; wings waved, long and broad, concealing the keel. Flowers two to four, on long, strong stems. Fragrant. Bloom medium. Plant of medium height and stout, healthy growth.

Comparison - Not so large as Elsie Herbert, but otherwise similar to it.

\section{DISTINCTION}

Originated by Bath.

Introduced by Bath, I 9 I 0.

Donated by Bath, I9Io.

Description in brief - Large, waved, picotee-edged pink on a white ground.

Comparison - Very similar to Elsie Herbert.

Remarks - Not a fixed stock.

\section{ELSIE HERBERT}

Originated by Breadmore.

Introduced by Brcadmore, 1908.

Donated by Dobbie, Miss Hemus, Unwin, 1910; Burpee, I9I I Morse, 1912.

Description in brief - Large, waved, picotee-edged pink on a white ground. A garden, market, or exhibition variety.

Description in detaii - Color of standard lilacy white $7(2-3)$, with a picotee edge of purple-rose 150 (I); wings 7 (1), with pale lilac-rose $130(4)$ edge. Standard large, Spencer-waved; wings large, partly open, waved. l'lowers two to four, on long, strong stems. Fragrant. Bloom profuse, continuous. Plant of tall, stout, healthy growth. Seed black.

Remarks - l'ure stocks. A distinct variety. The standard variety of this color. 
Originated by Unwin.

\section{ERIC HARVEY}

Donated by Unwin, for advance trial, 1910.

Description in brief - A large, beautifully waved flower, useful for decoration and exhibition.

Description in detail - Color of bud buff; opening flower shows trace of buff; standard suffused with mauve-rose, deepest at the edges, and deeper still on the back; wings flushed lilacy white 7 (4). Standard large, waved; wings large, varying from hooded to waved, concealing the keel. Flowers three, on long, strong stems. Plant grows to medium height, strong and healthy.

Comparison - Distinct from Martha Washington.

Remarks - Contained John Ingman rogue.

\section{MARTHA WASHINGTON}

Originated by Routzahn.

Introduced by Henderson, 1910.

Donated by Henderson, I910, I9II.

Description in brief - A very large, waved variety, with a heavy picotee edge on a pure white ground.

Description in detail - Color of standard white from base to center, shading to a pink edge; as the flower ages the suffusion increases; wings picotee-edged pink. Standard large, Spencer-waved; wings long and broad, waved.

Comparison - Distinct from Elsie Herbert.

Remarks - The 1910 stock produced one plant of Othello, but the variety is usually reported true. The igir stock was true.

\section{PICOTEE}

Originated by

Introduced by Watkins \& Simpson, 1910.

Donated by Watkins \& Simpson, 1910; Boddington, 191 I; Rohnert, I9I2.

Description in brief - A waved, picotee-edged carmine variety.

Description in detail - Color of standard faintest blush, edged with purple-rose 150

$(\mathrm{I}-3)$; wings edged with pale pink. Flower very large, waved form; standard very large, much waved; wings long and broad, spreading, often drooping. Very fragrant. Bloom profuse. Plant of tall, strong growth. Leaflets broad, pointed; tendrils green.

Comparison - Similar to Elsie Herbert and Distinction.

\section{WINIFRED DEAL}

Originated by Deal.

Introduced by Deal, I910.

Donated by Deal, 1910, 1912.

Description in brief - Large, waved, picotee-edged pink on a white ground.

Comparison - Similar to Elsie Herbert.

Remarks - Not a true stock. The 1912 stock was true.

\section{Pink}

Originated by Breadmore.

\section{AUDRY CRIER}

Donated by Rawson, I9Io.

Introduced by Breadmore, 1908.

Description in brief - Described as salmon-pink. 
Remarks - One of the varieties that it has been impossible to fix. This stock was almost entircly Helen Lewis, with onc plant Prince Olaf, two Menie Christie, and several White Spencer.

\section{BEATRICE SPENCER}

Originated by Morse.

Introduced by Morse, 1909.

Donated by Boddington, Morse, I9I0; Burpee, I9II.

Descriplion in brief-Catalogued as white, tinted soft pink and buff; wings have bright pink blotch at base.

Description in detail - Color of standard mauve-rose I 53 (2); wings violet-rose I 54 (I). Flower large; standard large, Speneer-waved; wings long and broad, waved. Flowcrs three, on strong stems of fair length. Bloom profuse, continuous. Plant of strong, healthy growth. Tendrils colored. Seed large, black.

\section{BLUSH ROSE SPENCER}

Originated by

Introduced by Henderson, 1910.

Donated by Henderson, I9IO.

Description in brief - A large, rose-pink, waved variety.

Description in detail - Color of standard purple-rose $\mathbf{1} 50$ (I-2); wings mauve-rose I53 (I). Standard and wings large and waved.

Remarks - A badly mixed lot of plants containing mostly carmine-rose flowers, with Countess Spencer and White Spencer.

\section{COUNTESS SPENCER}

Originated by Cole.

Introduced by Sydenham, 1904 .

Donated by Boddington, Cole, Dobbie, Henderson, Morse, Rawson, I9Io.

Description in brief - A large, rose-pink, waved variety, suitable for garden, market, and exhibition use.

Description in detail-Color of standard mauve-rose 153 (2-3); wings violet-rose

I $5+(\mathrm{I}-2)$; color deeper in cool weather; color often deeper at the edges. Standard very large, waved; wings waved, long and broad. Flowers three to four, on long, very strong stems. Fragrant. Bloom profuse, continuous. Plant of strong, vigorous growth. Seed black.

Remarks - One stock pure. The forerunner of the waved, or Spencer, type.

\section{ENCHANTRESS}

Originated by Stark.

Introduced by Stark, I906.

Donated by Boddington, Stark, I9io.

Synonyms - Identical with Countess Spencer.

Remarks - Neither stock pure.

\section{FLORENCE SPENCER}

Originated by Cole.

Introduced by Cole, 1907.

Donated by Rawson, 1910.

Description in detuil - Color of standard violet-rose $15+(2-3)$; wings $15+(\mathbf{I}-2)$. Flower of medium size, waved; standard of medium size, slightly waved; wings long and narrow. Flowers two to three, on long, slender stems. Productive. Plant of tall, strong growth. Lcaflets broad, dark green.

Comparison $-\Lambda$ trifle lighter in color than Countess Spencer.

Remarks - Not pure; contains Helen Lewis and E. J. Castle. 


\section{GLADYS UNWIN}

Originated by Unwin.

Introduced by Unwin, and Watkins \& Simpson, 1905.

Donated by Boddington, Rawson, and Watkins \& Simpson, 1910.

Description in brief - A rose-pink variety, of Unwin form; for garden or market use.

Description in detail - Color of standard mauve-rose I 53 (I); wings violet-rose I 54 (I).

Flower large; standard moderately large, slightly waved; wings long and broad,

hooded. Flowers two to three, on long stems. Productive. Produces a good crop of seed.

Comparison - Paler than Countess Spencer in cool weather. Standard more nearly' upright and wings more incurved than those of Countess Spencer.

Remarks - Two stocks pure.

\section{HERCULES}

Originated by Stark.

Introduced by Stark, I9I I.

Donated by Stark, 1912; Boddington, 1913.

Description in brief - A very large, waved, pink self.

Description in detail - Color same as Countess Spencer. Flower very large, slightly waved form. Flowers three to four, on long, strong stems. Tendrils colored.

Comparison - A larger, but less waved, Countess Spencer. Better for exhibition than Countess Spencer.

\section{LADY SARAH SPENCER}

Originated by Cole.

Introduced by Cole, igio.

Donated by Cole, igro.

Description in brief - Originator describes as pink suffused with salmon.

Synonyms - Same as Countess Spencer in all respects.

Remarks - Stock pure but not true.

\section{LOVELY SPENCER}

Originated by Morse.

Introduced by Morse, I909.

Donated by Morse, 1910.

Descripticn in brief - Large, waved form of Lovely.

Description in detail - Color of standard pale lilac-rose I 30 (2); wings I30 (3). Flower very large; standard large, Spencer-waved; wings large, long and very broad, waved, spreading. Flowers two to four, on long, strong stems. Bloom profuse, continuous. Plant of strong, healthy growth.

Comparison - Lighter in color than Countess Spencer.

Remarks - A distinct variety. A pure stock.

\section{MARION}

Originated by

Introduced by Dobbie, I9II.

Donated by Dobbie, 1912.

Description in detail - Color of standard and wings violet-rose $\mathbf{r}_{5+}(\mathrm{I}-2)$. Flower large, waved form; standard large, broad, slightly waved; wings long and broad. Flowers three, equidistant on medium stems. Very fragrant. Moderately productive. Plant of medium height and slender, healthy growth. Leaflets broad, pointed; tendrils colored.

Remarks - Has been described as lilac-rose. 


\section{MRS. ALFRED WATKINS}

Originated by Unwin.

Introduced by Unwin, and Watkins \& Simpson, 1907.

Donated by Boddington, Rawson, Unwin, and Watkins \& Simpson, I9Io.

Description in brief - Pale pink with lighter edges, Unwin type. A garden or market variety.

Description in detail - Color lilac-rose $\mathrm{I} 30(\mathrm{I}-2)$, fading to almost white edges. Flower

large, Unwin type; standard large, slightly waved; wings long and broad. Flowers

three, on long stems. Productive. Burns more or less in the sun.

Comparison - Does not resemble Peach Blossom very closely.

Remarks - Three stocks pure. One stock contained one Captain of the Blues Spencer.

\section{PARADISE}

Originated by Miss Hemus.

Introduced by Miss Hemus, Sydenham, 1907.

Donated by Boddington, Miss Hemus, Morse, Rawson, 1910.

Description in brief - A large, pink, waved variety.

Synonyms - Same as Countess Spencer.

Remarks - Miss Hemus' stock pure.

\section{ZARA}

Originated by Biffen.

Introduced by Miss Hemus, 1908.

Donated by Miss Hemus, 1910.

Description in brief - A garden varicty.

Description in detail - Color of standard hydrangea pink I32 (2-3); wings 132 ( $1-2)$.

Flower large, Unwin form; standard large, slightly waved; wings medium, partly

open. Substance good. Flowers two to four, on moderately long, strong stems.

Fragrant. Bloom free. Plant healthy and of medium height.

Comparison - More buff than Lovely Spencer.

Synonyms - We should call it Honorable F. Bouverie Spencer.

Remarks - A pure stock.

Pink (Pale pink group)

\section{CHARM}

Originated by

Introduced by Burpee, I9I3.

Donated by Burpee, 1913.

Description in detail - Color of standard lilac-rose i78 (I or paler). Flower large, waved form; standard large, slightly waved; wings short and broad, concealing the keel. Flowers three to four, irregularly placed on strong stems of medium length. Moderately fragrant. Moderately productive. Sunproof. Plant of medium height and slender growth. Leaflets dark green, broad, pointed; tendrils green.

\section{ELFRIDA PEARSON}

Originated by J. R. Pearson \& Sons.

Introduced by Pearson, I9II.

Donated by 1)obbie, 1912; Burpee, 1913.

Description in brief - $A$ large, waverl, blush-pink variety.

Description in detail - Color lilac-rose 152 ( 1 to much lighter); flower opens with considerable primrose in the standard, which is blush-pink; flower changes, losing its 
primrose tint, becoming a blush-pink on white. Flower large, waved form; standard large, waved, often double, sometimes triplc. 'Plant of tall, strong, vigorous growth. Foliage dark green, healthy.

Comparison - Not so large as Princess Victoria, but more salmon. A deeper pink than Lady Evelyn Eyre.

Rose

\section{EDNA TURNER}

Originated by Dipnall.

Introduced by Dipnall, I9I.

Donated by Dipnall.

Description in detail - Color of standard and wings purple-rose 150 (I). Flower large, waved form; standard large, slightly waved; wings long and broad, spreading. Moderately fragrant. Moderately productive. Burns slightly. Stems medium to long, slender. Plant of tall, strong growth. Leaflets broad.

Remarks - Two color rogues: (I) dark violet, (2) carmine-lake and orange.

\section{KING MAR JORIE}

Donated by Dobbie, 1912.

Description in detail - Color of standard lilac-rose $152(3-4)$, shading into Tyrian rose I 55 ( I-2); wings Tyrian rose $\mathbf{I} 55(\mathrm{I}-2)$. Flower very large, waved form; standard very large, slightly waved; wings long and broad. Good substance. Flowers two to three, equidistant on long, strong stems. Fragrance none. Bloom scant. Sunproof. Plant of very tall, stout growth. Leaflets broad, pointed. Comparison - An improved Marjorie Willis.

\section{MARIE CORELLI}

Originated by

Introduced by Burpee, Morse, I9IO.

Donated by Burpee, Morse.

Description in brief - A waved "rose-carmine" variety.

Description in detail - Color of standard purple-rose 150 (3-4); wings purple-rose I5O (I-2). (See description of Marjorie Willis.)

Remarks - A pure stock.

\section{MAR JORIE WILLIS}

Originated by Lumley.

Introduced by Lumley, Breadmore, Wright, 1908.

Donated by Dobbie, I910; Rohnert, I9I2; Burpee, I913.

Description in brief - A large, waved, rose and carmine variety, for garden and exhibition use.

Description in detail - Color of standard carmine-purple I5० (3); wings Tyrian rose I50 (I-2). Standard large, Spencer-waved; wings long and broad, concealing the keel. Flowers two to three, on long, strong stems. Very fragrant. Bloom profuse. Sunproof. Plant of medium height and stout, healthy growth. Tendrils colored; color in axils of leaves and leaflets.

Comparison - Very similar to Marie Corelli.

Remarks - A pure stock. 


\section{ROSABELLE}

Originated by Malcolm.

Introduced by Malcolm, I9I2.

Donated by King, 1913.

Description in brief $-\Lambda$ large, waved, rose variety.

Description in detail - Color of standard carmine-purple 156 (I), tinged with violet at

the base; wings pure mauve $18 \mathbf{1}(\mathbf{1}-2)$. Flower large, waved form; standard large, waved; wings short and broad, concealing the keel. Flowers three, on strong stems. Moderately fragrant. Bloom profuse. Burns slightly. Plant of tall, strong, vigorous growth. Leaflets broad, round, dark green.

Comparison - Superior to Marjorie Willis or Marie Corelli.

\section{ROSE DIAMOND}

Originated by Aldersey.

Introduced by Aldersey, 1912.

Donated by Aldersey, I9I2.

Description in brief - A large, waved, rose variety.

Description in detail - Color of standard carmine-lake I2 I (2-3); wings carmine-lake 12 I (I-2). Flower large, waved form; standard large, slightly waved; wings long and broad, spreading. Flowers three, irregularly placed on short, slender stems. Slightly fragrant. Moderately productive. Plant of medium height and slender growth. Leaflets narrow, pointed; tendrils colored.

Comparison - Lighter, purer rose shades than George Herbert.

\section{Salmor Shades}

\section{BARBARA}

Originaled by Holmes.

Introduced by Sydenham, Holmes, 1912.

Donated by Sydenham, I9I2.

Description in brief - A salmon-orange self.

Description in detail-Color of standard shrimp pink $75(2-3)$; wings madder lake $122(\mathrm{I}-2)$. Flower very large, waved form; standard very large, slightly waved; wings long and broad, spreading. Flowers two to three, on strong stems of medium length. Little, if any, fragrance. Moderately productive. Burns badly. Is badly injured by wet weather. Plant of medium height, strong. Leaflets broad, pointed; tendrils often colored.

Comparison - Flowers larger, bloom better, and stems stronger than Stirling Stent, but a lighter orange. A lighter orange than Thomas Stevenson.

\section{EARL SPENCER}

Originaled by Cole.

Introduced by Dobbie, Cole, 1910.

Donated by Boddington, I9II; Burpee, I9I3.

Descriplion in brief - A large, waved, orange varicty.

Description in detail - Color of standard and wings salmon-pink I26 (1-2). Flower large, waved form; standard large, slightly waved; wings long and broad, concealing the keel. Flowers two to three, equidistant, close, on short to medium stems of medium strength. Not fragrant. 13loom profuse. Burns badly. Plant of medium height and strong growtl. Leaflets broad, round, dark green. 


\section{INSPECTOR}

Originated by Dobbie.

Introduced by Dobbie, 1913.

Donated by Dobbie, I9I3.

Description in brief - A duplex, or double, form of Stirling Stent.

Description in detail - (See Stirling Stent.)

Comparison - Is a strain of Stirling Stent producing a good percentage of doubles. If anything, it is of more vigorous growth than Stirling Stent.

Remarks - A very good duplex variety.

\section{MELBA}

Originated by Malcolm.

Introduced by Dobbie, I9I2.

Donated by Dobbie, 1912; Burpee, Dobbie, 1913.

Description in brief - An orange-salmon flower.

Description in detail - Color of standard salmon-carmine 125 (3-4), deepest on back; wings salmon-carmine I25 (I-2). Flower large, waved form; standard large, slightly waved, sometimes double; wings long and broad. . Flowers two to three, on medium stems. Bloom profuse. Burns badly. Is badly injured by wet weather. Plant of medium height and strong growth. Leaflets broad, pointed; tendrils green.

Cimparison - Is smaller and lighter, and has much more orange, than Helen Lewis. Burned less in I9I 3 trials than Earl Spencer.

\section{STIRLING STENT}

Originated by James Agate.

Introduced by Agate, 19I1.

Donated by Boddington, 1911; Burpee, 1912, 1913.

Description in brief - A bright salmon-orange variety.

Description in detail-Color of standard madder lake I22 (2-4), back I22 (4); wings madder lake I22 (I-2), back I22 (3-4). Flower large, waved form; standard large, slightly waved; wings short and broad, concealing the keel. Flowers two to three, on medium stems. Not fragrant. Bloom profuse. Burns slightly. Plant of medium height and stout growth. Leaflets broad, pointed, dark green. Comparison - A deeper color, with much less burning, than Earl Spencer.

\section{TORTOISE SHELL}

Originated by Aldersey.

Introduced by Aldersey, 1910.

Donated by Aldersey, I912.

Description in brief - A shrimp pink variety.

Description in detail - Color of standard and wings shrimp pink 75 (2-3), veined darker. Flower of medium size, waved form; standard of medium size, slightly waved; wings long and broad, spreading. Flowers one to three, on medium stems. No fragrance. Bloom rather scant. Burns badly. Plant of medium height and slender growth.

Comparison - Color not so bright as Barbara.

Remarks - A pleasing, distinct color among new types.

Scarlet

Originated by Bolton.

\section{BOLTON'S SCARLET}

Donated by Boddington, I913.

Description in brief - A large, waved, crimson variety.

Introduced by Bolton, 1913. 
Description in detail - Color of standard crimson-red $11+(\mathbf{I}-2)$; wings amaranth-red I68 (1-2). Flower large, waved formi; standard large, slightly waved; wings long anel broal, concealing the kecl. Flowers three, on medium stems. Moderate fragrance. Bloom medium. Burns slightly. Plant of tall, slender growth. Leaflets broad, round, dark green.

Remarks - Stock pure, true.

\section{DOBBIE'S SCARLET}

Originated by Dobbie.

Introduced by Dobbie, 1913.

Donated by Dobbic, 1912, 1913.

Description in detail - Color of standard varies from crimson-red $11+$ ( 1 ) to carminered I 6 (I); wings crimson-red i It (I). Flower large, waved form; standard large, much waved, many double; wings long and broad, spreading. Flowers two to three, on long, strong stems. Fragrance moderate. Moderately productive. Sunproof. Plant of tall, strong growth. Leaflets broad.

Comparison - Similar to George Stark.

Remarks - In 1913 the best of the scarlets.

\section{DORIS BURT}

Originated by Unwin.

Introduced by Unwin, I9ı.

Donated by Unwin, I910.

Description in brief - A large, scarlet, waved, garden variety.

Description in detail - Color of standard carmine-purple 156 (3). Wings long and broad, concealing the keel. Flowers three, on long stems. Very slight fragrance.

Burns badly. Plant slender, of medium height. The foliage has a blue cast, the young shoots a purplish cast.

Remarks - A pure stock.

\section{GEORGE STARK}

Originated by Stark.

Introduced by Stark, 19 I0.

Donated by Stark, I910.

Description in brief - Medium to large, bright red.

Description in detuil - Color of standard carmine-purple 156 (3-4); wings 156 (1).

Standard medium to large, upright, open, flat or very slightly waved; wings long and broad, spreading. Flowers three, on long, strong stems. Mild fragrance.

Bloom profuse. Plant of moderately strong growth. Calyx colored.

Remarks - Wings sometimes larger than standard. A pure stock as to color.

\section{GEORGE STARK IMPROVED}

Originated by Stark.

Introduced by Stark, 1910.

Donated by Stark, 1910; Boddington, 1912.

Description in brief - A large, waved, scarlet variety suitable for all purposes.

Description in detail - Color of standard 156 (3-4); wings 156 (1). Standard large

to very large. Spencer-waved, many double; wings long and broad, spreading.

Flowers three, on long, strong stems. Very slight fragrance, if any. Bloom pro-

fuse. Burns in the sun. Growth strong and vigorous. Calyx colored.

Comparison - Color of Queen Alexandra.

Remarks - There is a clouble-flowered strain offered by Stark. 


\section{GEORGE WASHINGTON}

Originated by

Introduced by Henderson, 1910.

Donated by Henderson.

Description in brief - "A very large crimson scarlet."- Henderson's catalogue.

Remarks - This stock unfortunately produced two shades of red in equal proportion.

Withdrawn after first season.

Originated by Unwin.

\section{MISS E. F. DRAYSON}

Donated by Unwin, I9I0.

Description in brief - A medium-sized, scarlet, Unwin variety.

Description in detail - Color of standard carmine-purple $156(3-4)$; wings, front 156 (I), back 156 (2). Standard of medium size, Unwin type; wings short and broad. Flowers two to three, on strong stems of moderate length. Burns slightly. Plant of short, slender growth. Seed round, black.

Comparison - Color between Coccinea and Queen Alexandra, but resembles the latter more closely.

Remarks - One maroon plant appeared in the stock.

Originated by Stark.

\section{PREMIER}

Donated by Stark, 1912.

Description in detail - Color of standard crimson-red II $(\mathbf{I}-3)$, back a deeper color; wings crimson-red IIt (I). Flower very large, waved form; standard very large, waved slightly; wings short and broad. Flowers irregular on long, strong stems. Not fragrant. Moderately productive. Sunproof. Plant of medium height and strong growth. Leaflets broad.

Comparison - A similar flower to that of George Stark, but the plant is stronger.

\section{RED PARADISE}

Criginated by Miss Hemus.

Introduced by Mișs Hemus, 1910.

Donated by Miss Hemus, 1910.

Description in brief - A medium-sized, waved, bright red variety.

Description in detail - Color of standard carmine-purple $156(3-4)$; wings $156(\mathbf{I}-2)$. Standard of medium size, slightly waved; wings long and narrow. Flowers on strong stems of moderate length. Fragrance very slight. Sunproof. Plant not healthy. Growth stunted apparently from some physiological affection. Foliage blue-green.

Remarks - Stock mixed, two shades of red. Owing to the disease mentioned above, the variety did not show up so well as it probably should have done.

\section{RED STAR}

Originated by Malcolm.

Introduced by Dobbie, I912.

Donated by Dobbie, 1912, 1913.

Description in detail - Color of standard carmine-purple $156(3-4)$; wings carminepurple $156(2-3)$. Flower large, open form; standard large, flat; wings long and broad. Moderately fragrant. Blocm scant. Burns slightly. Plant of tall, slender growth. Leaflets broad. 
Comparison - Slightly better than George Stark.

Remurks - It this station this variety is the best of the Queen Alexandra color.

\section{ROYAL SCARLET}

Originated by Aldersey.

Introduced by Aldersey, $191 \mathrm{I}$.

Donated by .Mdersey, 1912 (Aldersey's No. I39).

Description in brief - I large, waved, scarlet self.

Description in detail - Color geranium red III (1); wings the same color. Flowers

large, waved form; standard large, slightly waved; wings long and broad, spread-

ing. Flowers on short stems. No fragrance. Bloom seant. Burns slightly.

Plant of medium height and slender growth. Leaflets broad, pointed.

Comparison - id duller and paler red than King Edward VII.

\section{SCARLET EMPEROR}

Originated by Holmes.

Introduced by Holmes, Sydenham, 19 I2.

Donated by Sydenham, 1912, 1913.

Description in brief - A large, waved, crimson-scarlet self.

Description in detail - Color of standard and wings crimson-red IIt (I-2); wings

lighter inside. Flower large, waved form; standard large, waved; wings short and broad, wide-spreading. Flowers two to three, equidistant on strong, medium to long stems. Moderately fragrant. Bloom profuse. Sunproof. Plant of tall, strong growth. Leaflets broad, pointed.

Comparison-Is a better, clearer scarlet, blooms better, and burns less, than George

Stark. Is a better scarlet and blooms better than Red Star.

Remarks - The best scarlet in 1912 .

\section{SCARLET EMPRESS}

Originated by Holmes.

Introduced by Holmes, Sydenham, 1912.

Donated by Sydenham, 1912, 1913.

Description in brief $-A$ large, waved, scarlet variety.

Description in detail - Color of standard crimson-red $11+(1-2)$; wings the same color. Flower large, waved form; standard large, waved; wings short and broad, spreading. Flowers three, equidistant, close, on medium to long, strong stems. Noderately fragrant. Bloom profuse. Sunproof. Plant of medium height and stout growth.

Remarks - A good, bright, clear scarlet.

\section{SCARLET MONARCH}

Originated by Deal.

Introduced by Deal, 1911 .

Donated by Deal.

Description in brief - A crimson-scarlet self.

Description in detail - Color of standard currant red $115(2-4)$; wings currant red I 5 (1). veined darker. Flower large, waved form; standard large, waved slightly, with round, broad base; wings long and broad, spreading. Flowers two to three, on short stems. Scarcely any fragrance. Bloom moderate. Burns badly. Plant of tall, slender growth.

Remarks -- Stock pure and true to type. 


\section{VERMILION BRILLIANT}

Originated by Burpec.

Introduced by Burpee, 1912.

Donated by Burpec, Boddington, I9 12.

Description in detail - Color of standard crimson-red II4 ( $\mathrm{I}-3)$; wings crimson-red I 4 (I or lighter). Flower large, waved form; standard large, waved slightly; wings short and broad. Flowers two to three, irregularly placed on long, strong stems. Moderately fragrant. Moderately productive. Plant of tall, strong growth. Leaflets broad, pointed.

Striped and Flaked (Chocolate on gray ground)

\section{SENATOR SPENCER}

Originated by

Introduced by Burpee, 1910.

Donated by Burpee, Morse, 1910; Burpee, 191 I, 1912, 1913.

Description in brief - A large garden or exhibition variety, with chocolate-colored stripes on a white ground.

Description in detail - Color purple-brown $166(\mathrm{I}-2)$ stripes on a purplish-tinted white 6 (2) ground. Standard large, round, Spencer-waved; wings long and broad, waved. Flowers two to four, on long, strong stems. Fragrant. Bloom profuse, continuous. Sunproof. Growtl medium, stout, healthy. Seed very large, black.

Remarks - In I9IO the introducer's stock was fixed. The other stock contained Aurora. Later stocks were correct.

Striped and Flaked (Orange-scarlet stripes)

\section{AURORA SPENCER}

Originated by

Introduced by Burpee, Morse, I909.

Donated by Burpee, Morse, 1910; Burpee, 1911, 1912, 1913.

Description in brief - A large, waved, salmon-pink-striped variety, for garden, market, or exhibition use.

Description in detail - Color of stripes on standard salmon-pink 126 (4), on a creamy white ground; wings deep cerise $\mathbf{I} 23(\mathbf{I}-3)$. Standard large to very large, Spencerwaved; wings large, waved, concealing the keel. Flowers two to tinree, on strong stems of medium length. Fragrant. Bloom profuse, continuous. Sunproof. Plant of strong, healthy growth.

Remarks - The standard variety of this color.

Originated by Miller.

Introduced by Miller, 1910.

Donated by Miller, I910.

Description in brief - A large, waved, salmon-pink-striped, garden variety.

Description in detail - Creamy white 10 (I) ground, with salmon-pink I26 (4) stripes on standard and deep cerise $123(\mathrm{I}-3)$ on wings. Standard large, waved; wings large to very large, waved, standing out at right angles to the standard, concealing the keel. Flowers two to three, on stems of moderate length. Fragrance moderate. Bloom profuse. Blackens in bright sunshine. Plant strong, vigorous, healthy. Comparison - Same color as Aurora Spencer, and not affected by the sun. Remarks - A fixed stock. 


\section{MRS. W. J. UNWIN}

Originated by Unwin.

Introduced by Unwin, I9II.

Donated by Unwin, for advance trial.

Description in brief - A large flower, striped with bright rosy scarlet; for garden, market, or exlibition use.

Description in detail - Color of stripes on standard bright rosy scarlet I24 (4); on wings almost carmine-lake 12 I (I), but more salmony. Standard large, Spencerwaved; wings large, waved, partly open. Flowers three, on long, strong stems. Fragrance slight. Bloom profuse, continuous. Plant of strong, healthy growth. Comparison - Color deeper and brighter than Aurora.

Remarks - A fixed stock. This variety is not synonymous with Aurora, as is sometimes reported; repeated trials indicate that it is distinct.

\section{STARK'S ELEGANCE}

Originated by Stark.

Introduced by Stark, I909.

Donated by Rawson, I9Io.

Descriplion in brief - A medium-sized flower, striped with rosy scarlet; a garden varicty.

Descriplion in detail - Color of stripes on standard bright rosy scarlet $12+(2-3)$; on wings I2t (I-2). Standard of medium size, upright; wings hooded, upright, long and narrow, concealing the keel. Flowers two to three, on short stems. Slight fragrance. Bloom free. Burns slightly. Plant of medium height and slender growth.

Comparison - Inferior to Aurora Spencer.

Remarks - Contained one plant of Salopian. Has no value.

Striped and Flaked (Pink on primrose grnind)

\section{ETHEL ROOSEVELT}

Originated by

Introduced by Burpee, I9II.

Donated by Burpee, for tdvance trial, 1910, under name Lottic Hutchins Spencer.

Description in brief - Large, waved, primrose striped with light pink; a garden or exhibition variety.

Description in detail - Color pale lilac-rose I $30(4)$ stripes on a y"ellowish white I 3 (2-3) ground. Standard large, waved; wings large, long and broad, partly open. Flowers two to three, on medium stems. Slightly fragrant. Bloom profuse. Sunproof. Plant of medium height and slender, healthy growth.

Remarks - A fixed stock. Sent out as Ethel Roosevelt in 1911.

\section{MRS. H. D. TIGWELL}

Originated by Unwin.

Introduced by Unwin, I9I I.

Donated by Unwin, for advance trial, I9I0.

Description in brief - A large, waved flower, pink-striped on a creamy white ground.

Description in detail - Color pale lilac-rose I $30(t)$ stripes on a creamy white $10(t)$ ground. Standard large, slightly waved; wings large, drooping, coneealing the keel. Poor substance. Some flowers do not open. Flowers two to three, on moderately long, strong stems. Mild fragrance. Bloom fair. Plant of tall, vigorous growth. Color in axils of leaves.

Comparison - Similar in color to Ethel Roosevelt, but of poor substance.

Remarks - A pure stock. 


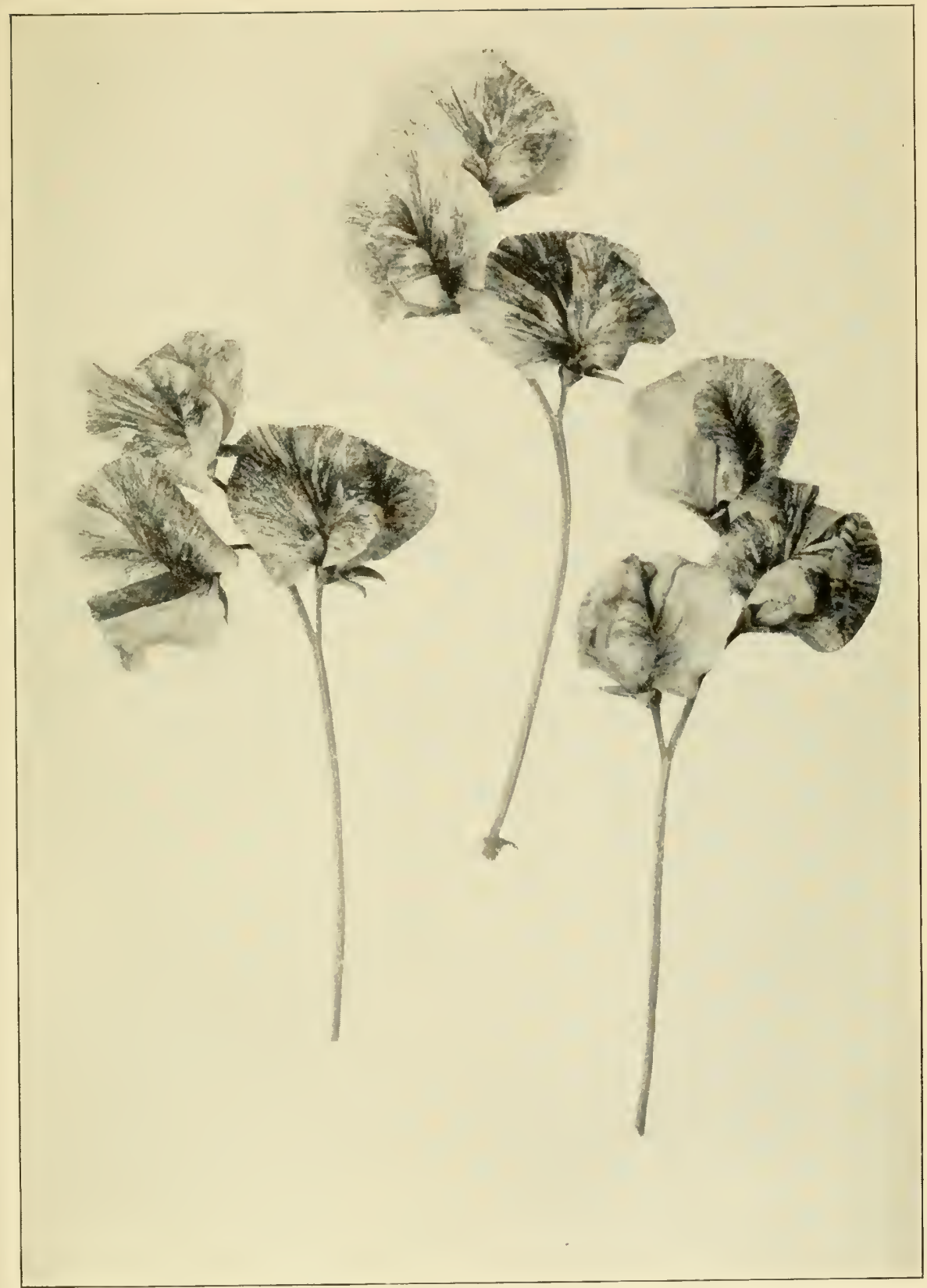




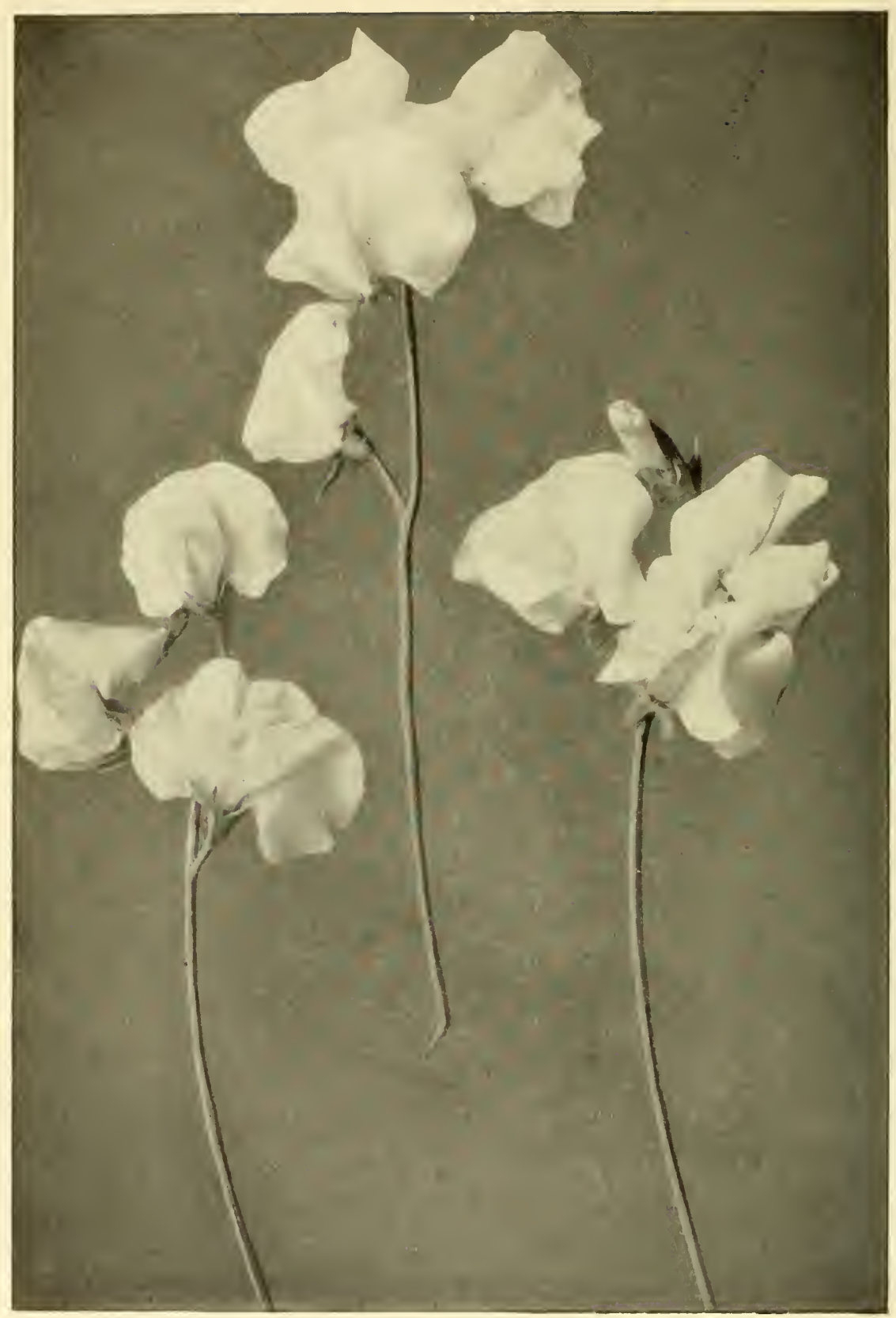

Ithite Spencer 


\section{ZENA}

Originatcd by Miss Hemus.

Introduced by Miss Hemus, 1910.

Donated by Miss Hemus, I910.

Description in brief - A large garden variety, with red flakes on a creamy white ground. Description in detail -Color pale lilac-rose $130(4)$ on a yellowish white $13(2-3)$ ground. Standard large, very slightly waved; wings large, partly open. Flowers three, on moderately long, strong stems. Bloom profuse. Plant of medium height and slender, healthy growth.

Comparison - Similar in color to Ethel Roosevelt.

Remarks - Contains a large number of mauve-striped flowers.

Striped and Flaked (Purple and blue)

\section{APRIL}

Originated by Dipnall.

Introduced by Dipnall, I913.

Donated by Dipnall, I912, I913.

Description in brief - A large, waved, blue-striped variety.

Description in detail - Color of standard and wings light bluish violet $202(\mathrm{I}-4)$ flaked and striped on a white ground. Flower large, waved form; standard large, slightly waved; wings large, long and narrow, spreading. Substance good. Flowers two to three, on medium stems. Moderately fragrant. Bloom not profuse. Plant of tall, stout, healthy growth. Leaflets broad, round, dark green.

Comparison - Quite distinct from Bertie Usher.

Remarks - Stock pure, true.

\section{BERTIE USHER}

Originated by Usher.

Introduced by Usher, 1912.

Donated by Sutton, 1912, 1913.

Description in brief - A large, waved flower, striped with violet-purple.

Description in detail - The standard and wings are striped and flaked with violetpurple 192 (I) on a white ground. Flower large, waved form; standard large, slightly waved; wings short and broad. Flowers three, equidistant on long, strong stems. Moderate fragrance. Moderately productive. Sunproof. Plant of very tall, stout growth. Leaflets broad, pointed; tendrils green.

Comparison - Similar in color to Loyalty, but has smaller flowers and is a less vigorous plant.

\section{BLUE FLAKE}

Originated by Unwin.

Introduced by Unwin, I9I0.

Donated by Unwin.

Description in brief - Light blue flake on white, Unwin form; a large garden variety.

Description in detail - Flower opens with considerable matve in the color, but changes to Parma violet $200(\mathbf{I}-2)$ stripes on the standard and $200(2-3)$ on the wings, with a lilacy white 7 (2) ground. Standard medium to large, Unwin form; wings large, hooded, concealing the keel. Flowers two to three, on medium stems. Fragrant. Bloom profuse, continuous. Plant of tall, strong, healthy growth.

Comparison -- Distinct from Paradise Blue Flake.

Remarks - A pure stock. 


\section{BLUE FLAKE SPENCER}

Originated by Box.

Introduced by Box, 1912.

Donated by Box, ig 12.

Description in brief - A large, blue-flaked variety.

Description in detail - Color of standard and wings violet-purple $192(\mathbf{I}-4)$. Flower

large, waved form; standard large, much waved; wings long and broad, spreading.

Substance good. Flowers three, on long, strong stems. Moderately fragrant. Bloom not profuse. Plant tall, strong. Leaflets broad, round; tendrils green.

\section{GEORGE CURZON}

Originated by Aldersey.

Introduced by Aldersey, 1912.

Donated by Aldersey, 1912.

Description in brief - Dark bluc flake.

Description in detail - Standard and wings have bright bluish flakes on a white or pale lavender ground. Flower large, waved form; standard large, slightly waved; wings long and broad, spreading. Flowers three, equidistant on melium stems. No fragrance. Bloom moderate. Sunproof. Plant of tall, strong growth. Leaflets broad, pointed; tendrils green.

Comparison - Not equal to Loyalty.

\section{LOYALTY}

Originated by Stark.

Introduced by Stark, 1912.

Donated by Stark, 1912.

Description in brief - A purple-violet flake on a white ground.

Description in detail - The standard and wings are striped purple-violet 192 (I) on a white ground. Flower very large, waved form; standard very large, much waved; wings short, broad. Substance good. Flowers three, on medium stems. Moderate fragrance. Bloom profuse. Plant of very tall, stout growth. Leaflets broad, pointed.

Comparison - Like Senator, except striped with blue. Better than Blue Flake Spencer. Remarks - The finest blue stripe. Stock pure, true.

\section{PARADISE BLUE FLAKE}

Originated by Miss Humus.

Introduced by Miss Hemus, I910.

Donated by Miss Hemus, 1910.

Descriptzon in brief - A large flower, having clear blue stripes on a white ground.

Description in detail - A purplish-tinted white $6\left(3^{-4}\right)$ ground, with Parma violet $200(3-4)$ stripes on standard and ageratum blue $201(1-2)$ on wings. Standard large, Spencer-wayed; wings hooked, long and broad, concealing the keel. Flowers three, on long stems of moderate strength. Fragrant. Bloom profuse, continuous. Plant of till, very vigorous growth.

Comparison - Opens with less matuve, is less striped, and shows more white ground than Blue Flake.

Remarks - A fixed stock. 
Striped and Flaked (Red on white ground)

\section{AMERICA SPENCER}

Originated by

Introduced by Burpee, I9II.

Donated by Burpee, I9I3.

Description in brief - Large, waved, red-flaked on a white ground.

Description in detail - Color of standard and wings rosy white 8 (I), striped with reddish purple I6I (I). Flower very large, waved form; standard large, waved; wings long and broad, concealing the keel. Flowers usually three, on strong, short stems. Moderately fragrant. Moderately productive. Sunproof. A garden or exhibition variety. Plant of medium height and stout, healthy growth. Leaflets dark green, broad, pointed; tendrils green.

\section{GAIETY SPENCER}

Originated by Morse.

Introduced by Burpee, I9I2.

Donated by Burpee, Morse, I912.

Description in brief - A waved variety.

Description in detail - The standard and wings are striped with purple-rose 150 (I) on a rosy white 8 (I) ground. Flower very large, waved form; standard very large, waved, some double; wings large, long and broad. Flowers three to four, well placed on very long, strong stems. Productive. Plant of strong, vigorous growth. Foliage rich dark green; tendrils colored; color in axils of peduncles and leaflets.

\section{JACK UNWIN}

Originated by Unwin.

Introduced by Unwin, 1909.

Donated by Unwin, I9I0.

Description in brief - A large, waved, red-striped variety, for garden or exhibition use. Description in detail - Color of stripes Rose Neyron red I 9 (2-3) on a white ground.

Standard large, slightly waved; wings large, hooded, concealing the keel. Flowers two to four, on long stems of moderate strength. Fragrant. Bloom profuse. Sunproof. Plant of medium height and strong, healthy growth. Color in axils of leaves.

Comparison - The Unwin form of Mrs. Joseph Chamberlain.

Remarks - A fixed stock.

\section{PARADISE RED FLAKE}

Originated by Miss Hemus.

Introduced by Miss Hemus, 1908.

Donated by Miss Hemus, I9IO.

Description in brief - A large, red-striped variety.

Description in detail $\rightarrow$ A rosy white ground $8(3-4)$, with stripes of madder carmine I 4 I (3-4) on standard and carmine-purple i56 (I) on wings. Standard large. upright, open; wings large. Flowers two to three, on moderate stems. Fragrance slight. Plant of strong growth.

Comparison - A heavier stripe than Jack Unwin. Very distinct from America in color.

Remarks - A pure stock. 


\section{RAINBOW SPENCER}

Originated by Morse.

Introduced by Morse, Burpec, 1912

Donaled by Burpee, Borklington, Morse, 1912.

Description in detail - A faint pink stripe on white. Flower very large, waved form; standard very large, waved; wings very large. Flowers on long, very strong stems.

Plant of strong, vigorous growth.

Comparison - Lurger than Gaicty Spencer.

Remarks - All stocks were one half to three fourths Gaiety Spencer.

\section{RAMONA SPENCER}

Originated by Morse.

Introduced by Morse, I909.

Donated by Bodklington, Morse, 1910; Burpec, I9I I, I9I2.

Description in brief $-\Lambda$ medium to large, waved flower, striped with pale rosy pink; a garden varicty.

Description in detail - Color of stripes rosy pink 1 i 8 (1) on a rosy white 8 ( I) ground. Standard medium to large, waved; wings of medium size, waved, concealing the keel. Flowers two to three, on fair stems. Nloderately fragrant. Bloom profuse, continuous. Plant of moderately vigorous, healthy growth. Flowers fade, becoming almost white.

Comparison - Rosabelle Hoare is a deeper stripe. Later stocks of this variety are superior to those of 1910 and have superseded Rosabelle Hoare.

Remarks - Too pale a stripe.

\section{RED FLAKE SPENCER}

Originated by

Introduced by Henderson, 1910.

Donated by Henderson, I9IO.

Description in brief - A red stripe on a white ground.

Synonyms - Synonymous with America.

Remarks - A mixed stock.

\section{ROSABELLE HOARE}

Originated by Unwin.

Introduced by Unwin, 1909.

Donated by Unwin, 1910.

Description in brief - A large, flaked variety, Unwin form.

Description in detail - Ground color rosy white 8 (4), with stripes of Rose Neyron red I I9 (1-2) on standard and rosy pink I I 8 ( I-2) on wings. Standard large, Unwin form; wings large, hooded, concealing the keel. Flowers three, on strong stems of moderate length. Irragrant. Bloom profuse, continuous. Sunproof. Plant of strong, healthy growth.

Comparison - Flowers deeper-colored than Ramona Spencer. After I9ro Ramona Sipencer was so much improved as to supersede Rosabelle Hoare.

Remarks - A fixed stock.

\section{UNCLE SAM}

Originated by Burpee.

Introduced by

Donated by Burpee, for advance trial.

Description in brief - A large, waved flower, with deep red stripes; a garden variety. 
Description in detail - Color of stripes on standard geranium red I I (I), on wings I I I (I-2), on a white ground. Standard large, slightly waved; wings large, partly open. Flowers two to three, on moderately long, strong stems. Plant of moderately tall, vigorous growth.

Comparison - Superior in size to Red Flake Paradise.

Remarks - A fixed stock. Should have been introduced in I911, as it was then the best crimson-striped variety.

Striped and Flaked (Rose on primrose ground)

Originated by Biffen.

ZEBRA

Donated by Miss Hemus, I9IO.

Description in brief-Large, "reddish mauve flake" on a creamy white ground; a garden or exhibition variety.

Description in delail - Standard striped with violet-rose $154(3-4)$, wings with 154 $(\mathbf{I}-2)$, on a creamy white Io $(\mathbf{I}-2)$ ground. Standard large, waved; wings long and broad, partly open. Flowers two to three, on strong stems. Moderate fragrance. Bloom free. Burns slightly. Plant of medium height and stout, healthy growth.

Remarks - A pure stock. Distinct in color from the other varieties here listed.

\section{White}

Originated by Cole.

\section{ALTHORP WHITE}

Donated by Cole.

Description in brief - A large, pure white, waved variety, for garden or exhibition use. Description in detail - Color milk white I I (2-3). Standard large, Spencer-waved, with round top; wings short, broad. partly open, waved. Flowers three, on long, strong stems. Moderately fragrant. Bloom profuse. Plant of moderately strong, healthy growth. Seed white.

Synonyms - A synonym of Etta Dyke.

Remarks - Stock pure.

Originated by Breadmore.

\section{ETTA DYKE}

Donated by Boddington, Dobbie, Rawson, Unwin, I9IO.

Description in brief - A large, pure white, Spencer-waved variety.

Description in detail - Color of standard and wings milk white I I (3-4). Flower large, waved form; standard large, much waved; wings long and broad, concealing the keel. Flowers three to four, irregularly spaced on long, strong stems. Very fragrant. Bloom profuse. Plant of medium height and strong, healthy growth. Tendrils green. Seed white.

Comparison - Similar to the best strains of Burpee's White Spencer.

Remarks - The English stocks of this variety in 1910 were superior to the American, not only in amount of waviness but also in purity of stock.

\section{FLORENCE WRIGHT SPENCER}

Originated by Stark.

Introduced by Stark, I9I3.

Donated by Stark, 1912.

Description in brief - A large, waved, white variety. 
Description in detail - Opens yellowish white 13 (1-2), farling to pure white. Flower very large, waved form. Substance good. Flowers three to four, on long, stout stems. Plant of tall, vigorous growth. Foliage dark green.

Comparison - A superior strain of Florence Wright.

\section{MRS. SANKEY SPENCER}

Originated by Morse.

Introduced by Morse, 1909.

Donated by Bodklington, Morse, 1910.

Description in brief - A large, wavel, white variety.

Description in detail - Color milk white 11 (1-2); shows a tinge of pink in opening buds, but fades to white. Standard large, Spencer-waved; wings long and broad, partly open. Flowers two to four, on long, strong stems. Fragrant. Bloom profuse, continuous, lasting well on plant. Sunproof. Plant of strong, vigorous growth. Seed large, round, dark brown.

Remarks - One stock pure.

\section{MONEYMAKER}

Originated by Agate.

Introduced by Agate, Lumley, i9 10.

Donated by Farquhar, 1913.

Description in brief - A very large, waved, white variety.

Description in detail - Color snow white 2 (I). Flower very latge, waved form; standard very large, slightly waved; wings large, short and broad. Flowers three, on long, strong stems. Fragrance moderate. Moderately productive. Sunprouf. Plant of tall, stout growth. Leaflets broad, round, dark green.

Remarks - Stock pure, true.

\section{NORA UNWIN}

Originated by Unwin.

Introduced by Unwin, and Watkins \& Simpson.

Donated by Boddington, Dobbie, Rawson, Unwin, and Wathins \& Simpson.

Description in brief - A large, pure white, waved variety, for garden or market use.

Description in detail - Color milk white II (3-4). Standartl large, slightly waved, with round top; wings long and broad, concealing the keel. Flowers two to four, mostly three, on long, strong stems. Noderately fragrant. Bloom profuse, continuous. Plant of tall, strong, healthy growth. Seed white. Germination forty to seventy-five per cent.

Remarks - I standard white variety.

\section{SNOWDON}

Originated by

Introduced by Watkins \& Simpson, I913.

Donaled by Bodklington, г9т.3.

Description in detuil - Color of standard and wings snow white 2 (1). Flower large, waved form; stanclard large, waverl; wings short and broanl, concealing the ked. Flowers three, on stems of medium length. Mloderate fratgrance. 13loom medium. Sumpronf. Plant of tall, slender growth. Leaflets broad, round, dark green. Remarks - Stock pure, true. 


\section{WHITE QUEEN}

Originated by Stark.

Introduced by Stark, I9I2.

Donated by Stark, I9I2.

Description in brief - A large, waved, white variety.

Description in detail - Opens yellowish white I3 (I), fading to pure white. Flower

large. Flowers three to four, on very long, strong stems. Plant tall, very vigorous. Foliage dark green, healthy.

Comparison - Superior to White Spencer.

Renarks - Should be given a trial.

\section{WHITE SPENCER}

Originated by Routzahn.

Introduced by Burpee, 1908.

Donated by Boddington, Henderson, Morse, Rawson, I9Io.

Description in brief - Large, pure white, waved, productive; a garden, market, and exhibition variety.

Description in detail - Color of flower milk white I I (3-4). Standard large, Spencer* waved, with round top; wings long and broad, waved, partly open. Flowers two to four, usually three, on long, strong stems. Fragrant. Bloom profuse. Midseason. Plant of tall, healthy, vigorous growth. Seed white. Germination seventy to eighty per cent.

Synonyms - The true flowers of this variety are identical with Etta Dyke, under which name it is known in England.

Remarks - Two of the stocks received in 1910 were pure as to color, but all gave some flowers that were not of the waved form. A standard white variety. 


\section{THE BEST VARIETIES OF SWEET PEAS}

The following list includes our selection from the hundreds of varieties tested under New York conditions. It is a matter of personal taste whether some of the color sections are desirable for any particular garden; howerer, it is easily possible to select those varieties that are suited to individual tastes.

WAVED VARIETIES

Bicolor - Mrs. Cuthbertson, Colleen.

Blue - Margaret Madison, Flora Norton Speneer, Bluc Jacket.

Blush - Lacly Evelyn Eyre, Princess Victoria, Florence Morse Spencer.

Carmine - John Ingman.

Cerise - Chrissie Unwin.

Cream, Buff, and Ivory - Primrose Spencer, Isobel Ma!colm, Primrose Beauty, Lady

Knox. Queen Victoria Spencer.

Cream-pink (Deep) - Mirs. Gibbs Box, Constance Oliver.

Cream-pink $($ Pale $)$ - Mrs. Routzahn, Lady Miller, Mrs. Hugh Dickson.

Crimson - King Elward Spencer.

Fancy - Afterglow.

Lavender - Florence Nightingale.

Magenta - Menie Christie.

Marbled - May Cimploell.

Maroon - Nubian, King Manoel.

Maroon-purple - Arthur Green.

Maroon-red - Brunette, Red Chief.

Mance (Dark) - Tennant Spencer.

Mawre (Pale) - Mrs. Heslington, Mauve Queen.

Orange-pink - Edrom Beauty, Carene, Helen Lewis.

Orange-scarlet - Thomas Stevenson.

Picotee edged (Cream ground) - Evelyn Hemus, Mis. C. W. Breadmore.

Picotee elged (Ithite ground) - Dainty Spencer, Elsic Herbert, Martha Washington.

Pink (Deep) - Hercules, Countess Spencer.

Pink (Pale $)$ - Elfrida Pearson.

Rose - Marie Corelli, Rosabelle.

Salmon Shades - Stirling Stent, Melba, Barbara.

Scurlet - Dubbie's Scarlet, Scarlet Emperor, Red Star.

Striped and Flaked (Chocolate on gray ground) - Senator Spencer.

Striped and Flaked (Purple and blue) - Loyalty.

Striped and Flaked (Red and rose) - America Spencer, Aurora Spencer, Mrs. IV. J. Unwin.

White - White Spencer, Nora Unwin.

\section{VARIETIES OF OPEN AND HOODED FORMS}

Bicolor - Blanche Ferry, Jeannie Gordon.

Blue - Brilliant Blue, Navy Blue.

Blue (Light) - Flora Norton.

Blush - Modesty.

Cerise - Coccinea. 
Cream, Buff, and Ivory - Zarina, The Honorable Mrs. E. Kenyon, Quecn Victoria.

Crimson - King Edward VII.

Lavender - Lady Grizel Hamilton.

Marbled - Helen Pierce.

Maroon - Black Knight, Othello.

Mauve - Admiration, Mrs. Walter Wright, Dorothy Tennant.

Orange Shades - Henry Eckford, Miss Wilmott.

Picotee edged - Dainty, Lottie Eckford, Phenomenal.

Pink - Prima Donna, Lovely, Katherine Tracy, Janet Scott.

Rose and Carmine - Lord Roseberry.

Scarlet - Queen Alexandra.

Striped and Flaked (Chocolate on gray ground) - Senator.

Striped and Flaked (Purple and blue) - Princess of Wales, Hester

Striped and Flaked (Red and rose) - America, Aurora, Ramona.

White - Dorothy Eckford, Shasta, Emily Henderson, White Wonder.

\section{EARLY-FLOWERING VARIETIES}

Bicolor - Earliest of All.

Blue - Le Marquis (described in Bulletin 319 of this station, page 655).

Lavender - Mrs. Alexander Wallace (described in Bulletin 319, page 653).

Primrose - Earliest Sunbeams.

Salmon-pink - Mrs. William Sim (described in Bulletin 3I9, page 648).

White - Earliest White, Mont Blanc.

\section{MARKET VARIETIES}

Open and hooded rarieties - Dorothy Echford, King Edward VII, Brilliant Blue, Lady

Grizel Hamilton, Prima Donna, Blanche Ferry.

Waved varieties - Countess Spencer, Nora Unwin, Asta Ohn, King Edward Spencer.

The market requires flowers of good substance, so that they will endure handling, and in good, clear colors. Pink, Pink and White, Lavender, and Red and White varieties are most in demand and these should comprise the greater part of the plantings. A few of the Blue, Cream-pink, and Primrose varieties may be sold. The number of blooms of the lastnamed that may be disposed of will depend on the market. The earlyflowering varieties mentioned above are suitable for market. 


\section{INDEX TO VARIETIES}

P.AGE

Acme. . . . . . . . . . . . . . 259

Blackbird.................. 266

Admiral Togo.

266

Admiration

275

Adonis

236

Afterglow.

309

Agnes Eckford.

259

Agnes Johnson

237

A. J. Cook.

322

Alba Magnifica .

252

Albatross.................

Albion

286

Alice Eckford

233

Althorp Cream

Althorp White.

America .

American Belle

American Queen

255

236

America Spencer

Amethyst. .

Andrew Aitken

Anglian Orange.

Annabel l.ce. . .

Annic B. Gilroy . . . . . . . . . . 262

Annic Stark. .

Apple Blossom

Apple Blossom Spencer

April.

Argosy .

Arthur Green

Arthur Unwin.

Asta Ohn

Audry Crier.

Aurora

Aurora Spencer

Azure Fairy

Baker's Scarlet

Barbara

Beacon

Beatrice Spencer

Bertha Massey

Bertie Hamilton

Bertie Usher.

Beryl................ 303

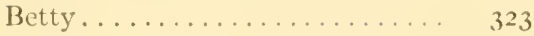

Black................ 243

Black Knight. . . . . . . . . . . 242

Black Michael............. 242

Blanche Burpee............ 285

Blanche Ferry... . . . . . . . . . . 229

Blanche Ferry Spencer. . . . . . . 290

Bluc Bcll (May)... . . . . . . . . . 231

Blue Belle (Bide)............ 232

Blue Bird... . . . . . . . . . . . 266

Blue Edged................ 246

Blue Flake................ 345

Bluc Flake Spencer. . . . . . . . . 346

Blue Jacket. . . . . . . . . . . . . 29

Blushing Beauty... . . . . . . . . . 259

Blushing Bride. . . . . . . . . . 229

Blush Queen... . . . . . . . . . . . 293

Blush Rose Spencer. . . . . . . . . . . 334

Bob.................... 264

Bobby K.................. 293

Bolton's Pink. . . . . . . . . . . . 276

Bolton's Scarlet. . . . . . . . . . . 339

Boreatton................ 243

Bride of Niagara. . . . . . . . . . . 229

Bridesmaid.............. 247

Brilliant.................. 264

Brilliant Bluc............. $25^{8}$

Britannia................. 284

British Queen.............. 26I

Bronze King............... 23I

Bronze Paradise............ 318

Bronze Prince.............. 23I

Brunctte............... 322

Butterfly.............. 277

Buttonhole.............. 277

California................. 259

Calypso................. 24

Caprice (Henderson) ......... 281

Caprice (Johnson) ... . . . . . . . 284

Captain Clarkc............. 246

Captain of the Blues......... 257

Captain of the Blues Spencer.... 321

Captivation............... 244

Captivation Spcncer.......... 306

Cardinal................ 238

Cardinal Wolscley............. 243

Carene................. $\quad 326$ 
PAGE

Carmen Sylva............ 24I

Carmine Invincible......... 238

Celestial

Chancellor

Charles Foster.

Charles Hemus.

Charm.

Chastity.

Chrissie Unwin

Clara Curtis.

Coccinea.

Coccinea Paradise.

Colleen.

Colonist

Columbia.

Constance Oliver.

Coquette.

Coral Gem .

Coronation (?).

Coronation (Bolton)

Coronet.

Cottage Maid

Countess Cadogan

Countess of Aberdeen

Countess of Lathom.

Countess of Powis

Countess of Radnor

Countess of Shrewsbury

Countess Spencer

Cream of Brockhampton

Creole.

Crimson Giant

Crimson Paradise.

Crown Jewel

Crown Princess of Prussia

Cyril Breadmore.

Cyril Unwin.

Dainty .

Dainty Spencer

David R. Williamson

Dawn (Stark)

Dawn (Walker)

Daybreak. .

Dazzler.

Delicata

Delight.

Devonshire Cream

Distinction. .

Dobbie's Cream.

238
271

277

309

318

336

332

296

297

262

297

290

260

250

301

255

263

237

303

249

259

257

260

263

245

$27 \mathrm{I}$

231

334

286

240

307

307

255

247

261

318

279

332

257

255

274

250

329

260

234

254

332

297
Dobbie's Scarlet..............

PAGE

Dolly Varden...............

340

Dora..................... 310

Dora Breadmore........... 270

Doris Burt............. 340

Doris Usher.............. 301

Dorothy Eckford........... 285

Dorothy Tennant............ 275

Dorothy Vick.............. 235

Double Duke of Clarence....... $\quad 268$

Double Primrose Beauty.... . . . 298

Douglas Breadmore.......... 28 I

Douglas Unwin............ 318

Dragonfly............... 310

Duchess of Edinburgh........ $\quad 235$

Duchess of Marlboro......... 247

Duchess of Sutherland........ 260

Duchess of Westminster....... 237

Duchess of York........... 251

Dudley Lees.... . . . . . . . . . . 268

Duke of Clarence............ 268

Duke of Clarence, Double (see

Double Duke of Clarence)

Duke of Kent............. 248

Duke of Sutherland.......... 268

Duke of Westminster......... 257

Duke of York............ 23I

Earl Cromer.............. 273

Earliest of All ............ 229

Earliest Sunbeams........... 254

Earliest White........... 252

Earl Spencer............. 338

Eastern Queen............ $\quad 282$

Edith Taylor............. $\quad 326$

Edna Turner.............. 337

Edna Unwin Improved........ $\quad 329$

Edrom Beauty........... $\quad 327$

E. J. Castle... . . . . . . . . . . 295

Elaine... . . . . . . . . . . . 298

Elfrida Pearson............. 336

Elfrieda................ $\quad 249$

Ella Kelway.............. 303

Elsie Herbert............. $\quad 332$

Emily Eckford ............ 275

Emily Eckford Spencer........ 323

Emily Henderson........... $\quad 252$

Emily Lynch.............. 255

Empress................ 324

Empress of India (Eckford)..... 232 
P.IGE

Empress of India (May).

Enchantress...

Enid.

Eric Harvey

Esmerakla.

Ethel Roosevelt........

Etna. .

Etta Dyke.

Evelyn Breaclmore.

Evelyn Byatt.

Evelyn Hemus

Evening Star. .

Exquisite

Extra Early Blanche Perry

Fadeless Scarlet Gem.

Fairy Queen

Fascination .

Fashion

Felicity....

Finetta Bathurst.

Firefly.

Flora Norton.

Flora Norton Spencer

Florence Fraser.

Florence Mlolyneaux.

Florence Mlorse Spencer

Florence Niglitingale.

Florence Speneer

Florence Wright Spencer.

Florist Lavender.

Florrie Crutcher

Forty-niner .

Frances Deal

Frank Dolloy . .

Frank Unwin.

Gaicty .

Gaiety Spencer

Garnet Spencer.

G. C. Waud. .

Gem

George Curzon

George Gorilon.

Gcorge Herbert.

George Stark

George Stark Improved

George Washington

Giant Cream Waverl.

Gladys Burt

Glartys French.
PAGE

Gladys Unwin............. 335

Glyn Turquand............. 327

Golden Gate............... $\quad 278$

Golden Gleam............... $\quad 287$

Golden Rose.............. 283

Gorgeous................ 245

Grace May.............. 252

Gracie Greenwood. . ......... 263

Gray Friar............. $27 t$

G. W. Kerr............. 263

Hannah Dale.............. 267

Harold . . . . . . . . . . . . . . 254

Harvard. . . . . . . . . . . . 265

Helen Grosvenor............ 327

Helen Lewis.... . . . . . . . . . . 327

Helen Pierce............... 24I

Helen Williams............. 33 I

Helio Paradise.............. 324

Heliotrope Spencer............ 324

Henry Eckford............. 248

Herbert Smith............. 245

Hercules................. 335

Her Majesty............... 26I

Hester. . . . . . . . . . . . . 249

Hetty Green............. 245

Hilda Jeffirey............. 255

H. J. R. Digges............ . 267

Holdfast Belle............ 304

Itonorable F. Bouveric........ 263

Horace Wright. . . . . . . . . . . 268

Ignea. . . . . . . . . . . . . . 265

Imperial Blue. . . . . . . . . . 258

Improved Dudley Lees......... 268

Inconstancy.............. $25 t$

Indigo King............... 269

Inspector . . . . . . . . . . . 339

Invincible Searlet. . . . . . . . . . 239

Invincible Scarlet Striped...... 251

Invincible Striped........... 25!

Irish Belle............. 3 II

Isa Eckford .............. 248

Isobel Malcolm............. 298

Ivanhoe............... 312

lvy Miller.............. 278

Jack Unwin.............. 347

James Grieve.............. 287

Janet Scott.............. 263

Jeannic Gordon............. 256

Jessic Cuthbertson. .......... 283 


\begin{tabular}{|c|c|c|c|}
\hline & $\mathrm{AGE}$ & & PAGE \\
\hline ( & 267 & Loyalty . & $3+6$ \\
\hline$\ldots \ldots \ldots \ldots$ & 296 & Madame Carnot.......... & \\
\hline$\ldots \ldots \ldots \ldots \ldots$ & 321 & Madeline Cole.............. & \\
\hline osephine White............. & 252 & Magnificent................ & \\
\hline$\ldots \ldots \ldots \ldots \ldots$ & 271 & Maid of Honor . . . . . . . . . . . & 279 \\
\hline$\ldots \ldots \ldots \ldots \ldots$ & $28 \mathrm{I}$ & Majestic................. & \\
\hline$\ldots \ldots \ldots \ldots$ & 304 & Malcolm's No. I $+\ldots \ldots \ldots \ldots \ldots$ & I 3 \\
\hline atherine Tracy. & $2+8$ & Mandoline.................. & 313 \\
\hline$\ldots \ldots \ldots \ldots \ldots$ & 269 & Iarbled Blue. ............. & \\
\hline$\ldots \ldots \ldots \ldots$ & 266 & Iarchioness of Cholmondeley . . . . & r \\
\hline Cing Edward Improved . . . . . . . & 239 & Iadison............ & 292 \\
\hline VII .......... & 239 & $\ldots \ldots \ldots \ldots \ldots$ & (53) \\
\hline Spencer.... . . . . . & 307 & $\ldots \ldots \ldots \ldots \ldots$ & 335 \\
\hline$\ldots \ldots \ldots \ldots$ & 319 & rie Willis............. & 37 \\
\hline$\ldots \ldots \ldots \ldots \ldots$ & 33 & $\mathrm{y} \ldots \ldots \ldots \ldots \ldots$ & \\
\hline$\ldots \ldots \ldots \ldots \ldots$ & 260 & Paradise . . . . . . . . & 321 \\
\hline$\ldots \ldots \ldots \ldots$ & 294 & $\ldots \ldots \ldots \ldots \ldots \ldots$ & 265 \\
\hline eld . . . . . . . . . & 232 & ington........... & 333 \\
\hline$\ldots \ldots \ldots \ldots \ldots \ldots$ & 272 & $n \ldots \ldots \ldots \ldots \ldots$ & 301 \\
\hline$\ldots \ldots \ldots \ldots$ & 230 & $\ldots \ldots \ldots \ldots \ldots$ & \\
\hline yre.......... & 294 & $\ldots \ldots \ldots \ldots \ldots$ & 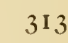 \\
\hline nilton.......... & $27^{2}$ & ise $\ldots \ldots \ldots \ldots \ldots$ & 325 \\
\hline 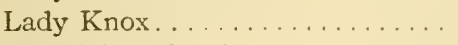 & 298 & $1 \ldots \ldots \ldots \ldots \ldots$ & \\
\hline $\operatorname{rrie} \ldots \ldots \ldots \ldots$. & 277 & $r \ldots \ldots \ldots \ldots \ldots$ & - \\
\hline$\ldots \ldots \ldots \ldots \ldots$ & 304 & $11 \ldots \ldots \ldots \ldots \ldots$ & 317 \\
\hline sore . . . . . . & 270 & $\operatorname{ar} \ldots \ldots \ldots \ldots \ldots$ & 292 \\
\hline$\ldots \ldots \ldots \ldots$ & 272 & $\ldots \ldots \ldots \ldots \ldots \ldots$ & $I^{\prime}$ \\
\hline r........ & 335 & Spencer.......... & 299 \\
\hline & 25 & $\ldots \ldots \ldots \ldots \ldots \ldots$ & 339 \\
\hline$\ldots \ldots \ldots \ldots$ & 32 & $e \ldots \ldots \ldots \ldots \ldots$ & 510 \\
\hline$\ldots \ldots \ldots \ldots \ldots$ & 312 & $\ldots \ldots \ldots \ldots \ldots \ldots$ & 246 \\
\hline$\ldots \ldots \ldots \ldots \ldots$ & 312 & e................... & 233 \\
\hline$\ldots \ldots \ldots \ldots$ & 23 & & 267 \\
\hline$\ldots \ldots \ldots \ldots \ldots$ & 292 & & $28+$ \\
\hline & 307 & $d \ldots \ldots \ldots \ldots \ldots \ldots$ & $2+6$ \\
\hline$\ldots \ldots \ldots \ldots \ldots$ & $28+$ & $\operatorname{slin} \ldots \ldots \ldots \ldots \ldots \ldots$ & 265 \\
\hline$\ldots \ldots \ldots \ldots \ldots$ & 294 & hnston............. & 236 \\
\hline & $3 \mathrm{I}$ & $\ldots \ldots \ldots \ldots \ldots \ldots$ & 252 \\
\hline & 23 & nell. . . & 302 \\
\hline$\ldots \ldots \ldots \ldots \ldots \ldots$ & 32 & rs. . . . . . . . & 272 \\
\hline Lo & 280 & iver. . . . . . . . . & 302 \\
\hline & 27 & Bostock..... & 264 \\
\hline$\ldots \ldots \ldots \ldots \ldots \ldots$ & $25^{8}$ & F. Drayson . .......... & $3+[$ \\
\hline Lor & 273 & hel............... & $23+$ \\
\hline & 29 & Miss $\mathrm{H}$ & 236 \\
\hline$\ldots$ & 278 & $\ldots$ & 277 \\
\hline$T_{0}$ & 283 & Miss Wilmott Improved. . . . . . . & 277 \\
\hline & 280 & Mrs. Alfred Watkins.... & 336 \\
\hline .0very spericet. & 335 & Mrs. A. Malcolm. & \\
\hline
\end{tabular}


P.icis

Mrs. Andrew Ireland . . . . . . . . . 290 290

Mrs. Bicberstedt............ . $\quad 276$

Mrs. Charles Masters. . . . . . . . 264

Mrs. Collier................ 287

Mrs. Cuthbertson............ 291

Mrs. C. W. Breadmore......... 331

Mrs. Dugdale. . . . . . . . . . . 260

Mrs. Duncan . . . . . . . . . . . . . . 308

Mrs. Eckford ................ $\quad 287$

Mrs. E. Cowdy............... . 321

Mrs. E. Gilman . . . . . . . . . . $\quad 256$

Mrs. E. Herbert . . . . . . . . . . . 280

Mrs. Fitzgerald.

Mrs. George Higginson, jr

Nrs. Gibbs Box

Mrs. Gladstone.

Mrs. Hardcastle Sykes

Mrs. H. D. Tigwell.

Mrs. Henry Bell.

Mrs. Heslington.

Mrs. H. Kendall Barnes.

Mrs. Hugh Dickson

Mrs. Isaac House.

Mirs. J. Miller.

Mrs. Joseph Chamberlain

Mrs. Knights-Smith

Mrs. Langtry.

Mrs. Reginald Hill.

Mrs. R. M. Shelton

Mrs. Routzahn.

Mrs. Sankey

Mrs. Sankey Speneer

Mrs. Stewart Champion .

Mrs. S. T. Walker

Mrs. Tom Fogg

Mrs. Walter Wright

Mrs. W. J. Unwin

Mociesty

Monarch

Moneymaker

Mont Blanc.

Moonstone.

Natoma. .

Navy Blue.

Negro. .

Nell Gwynne

Nellic Janes. .

Nettic Jenkins.

290

270

272

302

234

295

$3+4$

305

325

270

305

272

284

280

Now Comntess.

New Improver luey IIenus.

Nigger

Nita . .

Nora Unwin

Novelty. . . . . . . . . . . . . $\quad 236$

Nubian................. . 319

Nymphaca................. $\quad 279$

Oddity ............... 26I

Olive Ruffell . . . . . . . . . . . 303

Orange King . . . . . . . . . . . 330

Orange Perfection........... . 330

Orange Prince. . . . . . . . . . . 2 2 6

Orange Spencer............. 328

Orchid........................ 315

Oregoria............... 285

Oriental . . . . . . . . . . . . 277

Orion . . . . . . . . . . . . . 308

Othello................. $\quad 267$

Othello Spencer............. 319

Ovid ................... 261

Painted Lady ............ 230

Paradise................ 336

Paradise Beatuty. . . . . . . . . . . 299

Paradise Blue liake......... . 346

Paradise Carmine. . . . . . . . . $\quad 296$

Paradise Ivory . . . . . . . . . . . 299

Paradise Red Flake.......... 347

Paradise Regained. . . . . . . . . 295

Peach Blossom............ 248

Peacock............... $24+$

Pearl Grey ............... . 315

Perdita................ 27t

Phenomenal.............. 279

Phocbus................ 328

Phyllis Unwin ... . . . . . . . . 296

Picotee................ 333

Pink Friar. . . . . . . . . . $27 t$

Pink Snapdragon ............ 288

Premier. . . . . . . . . . . . 341

Prima Donnal. . . . . . . . . . . 280 .

Primrose.................. $\quad 254$

Primrose Beauty............ 299

Primrose Beauty, Double (sec

Double Primrose Beatuty)

258

$2+3$

303

230

3 It
Primrose Paradise

Primrose Spencer

Prince Edward of York........ $\quad 2.35$

Prince of Asturias........... 320 
P.IGE

Prince of Orange

Prince of $\mathrm{W}$ iales

Prince Olaf.

Princess Alice Spencer.

Princess Beatricc.

Princess Catherine

Princess Louise.

Princess Maud of Wales

Princess May

Princess of Wales.

Princess Victoria (Dobbie)

Princess Victoria (Eckford)

Purple....................

Purple Brown Stripe..........

Purple King.

Purple Prince.

Purple Prince Spencer.

Purple Snapdragon.

Queen Alexandra.

Queenie.

Queen Mary

Queen of England.

Queen of Mauves.

Queen of Pinks.

Queen of Spain.

Queen of the Isles.

Queen Victoria.

Queen Victoria Spencer

Rainbow Spencer.

Ramona.

Ramona Spencer

Red and White Striped.

Red Chief. .

Red Flake Spencer.

Red Paradise.

Red Riding Hond.

Red Star.

Regina

Reselected Extreme Early Earliest of All.

Rising Sun

Romolo Piazzani

Rosabelle.

Rosabelle Hoare

Rose Diamond

Rose Queen

Rosie Adams

Royal Purple...............

Royal Robe.
328

262

249

315

$2+8$

295

$24+$

262

240

$28 \mathrm{I}$

295

235

316

250

269

269

322

288

266

300

306

253

315

280

264

$25 \mathrm{I}$

$28 \%$

300

$34^{8}$

285

$3+8$

$25 \mathrm{I}$

322

$34^{8}$

$3+$ I

288

$3+\mathrm{I}$

$2+3$

$23^{\circ}$

$2+2$

276

338

$34^{8}$

338

$28 \mathrm{I}$

308

317

28 I
P.

Royal Rose.............. $\quad 256$

Royal Scarlet............. . 342

Royalty ............... $\quad 325$

Ruby................. 330

Ruby Palmer.............. 308

Sadie Burpee (black-seeded)..... $\quad 285$

Sadie Burpee (white-seeded) . . . . 286

Safrano.................. 288

St. George. . . . . . . . . . . . . 330

Salopian................. $\quad 265$

Salvation Lassie............. 289

Scarlet Emperor............. . 342

Scarlet Empress............ 342

Scarlet Gem............. 240

Scarlet Monarch............ 342

Seafoam............... $30 \mathrm{I}$

Senator............... $28 \mathrm{I}$

Senator Spencer............ $3+3$

Sensation ............... 260

Shahzada................ 267

Shasta................. 253

Shawondasee............. 292

Silas Cole............... $\quad 320$

Snowdon. . . . . . . . . . . . 350

Snowflake............... $\quad 253$

Southcote Blue............. 293

Speckled Beauty........... 274

Splendid Lilac............ 247

Splendour................ 262

Stanley................ $2+3$

Stark's Elegance............ $34+$

Stella Morse............. 27 I

Stirling Stent . . . . . . . . . 339

Striped Celestial............ $\quad 282$

Striped Tennant............ $\quad \mathbf{2} 82$

Sue Earl............... 271

Sultan............... $24+4$

Sunproof King ............ 309

Sumproof Salopian.......... 266

Sunrise................. 237

Sunset................ $\quad 283$

Sutton's Queen ............. 306

Sweet Lavender............ $\quad 317$

Sybil Eekford............ 240

Tennant Spencer........... 326

The Bride.............. $\quad 286$

The Fairy ............. $\quad 273$

The Honorable Mrs. E. Kenyon. . 288

The King .............. 309 
P.IGE

'The Marquis. . . . . . . . . . . . 326

The Quecu ... . . . . . . . . . . . . . 24. 24

Thomas Stevenson........... 331

Tortoise Shell. . . . . . . . . . . . . 339

Triumple.

Triumph spencer.

True Lavender

Tweedy Smith.

Uncle Sam.

Unique.

Venus.

Vermilion Brilliant.

Vesuvius.

Victor Unwin

Violet Queen

Walter P. Wright

Waverly.

Waverly Spencer
339
232

291

273

2.56

$3+8$

282

264

$3+3$

$2+2$

320

$2+4$

3 I 6

258

322
PAGE:

282

$2+1$

$3.5 \mathrm{I}$

280

$35 \mathrm{I}$

253

286

333

3 I 6

306

288

336

238

$3+9$

$3+5$

293

253

233 



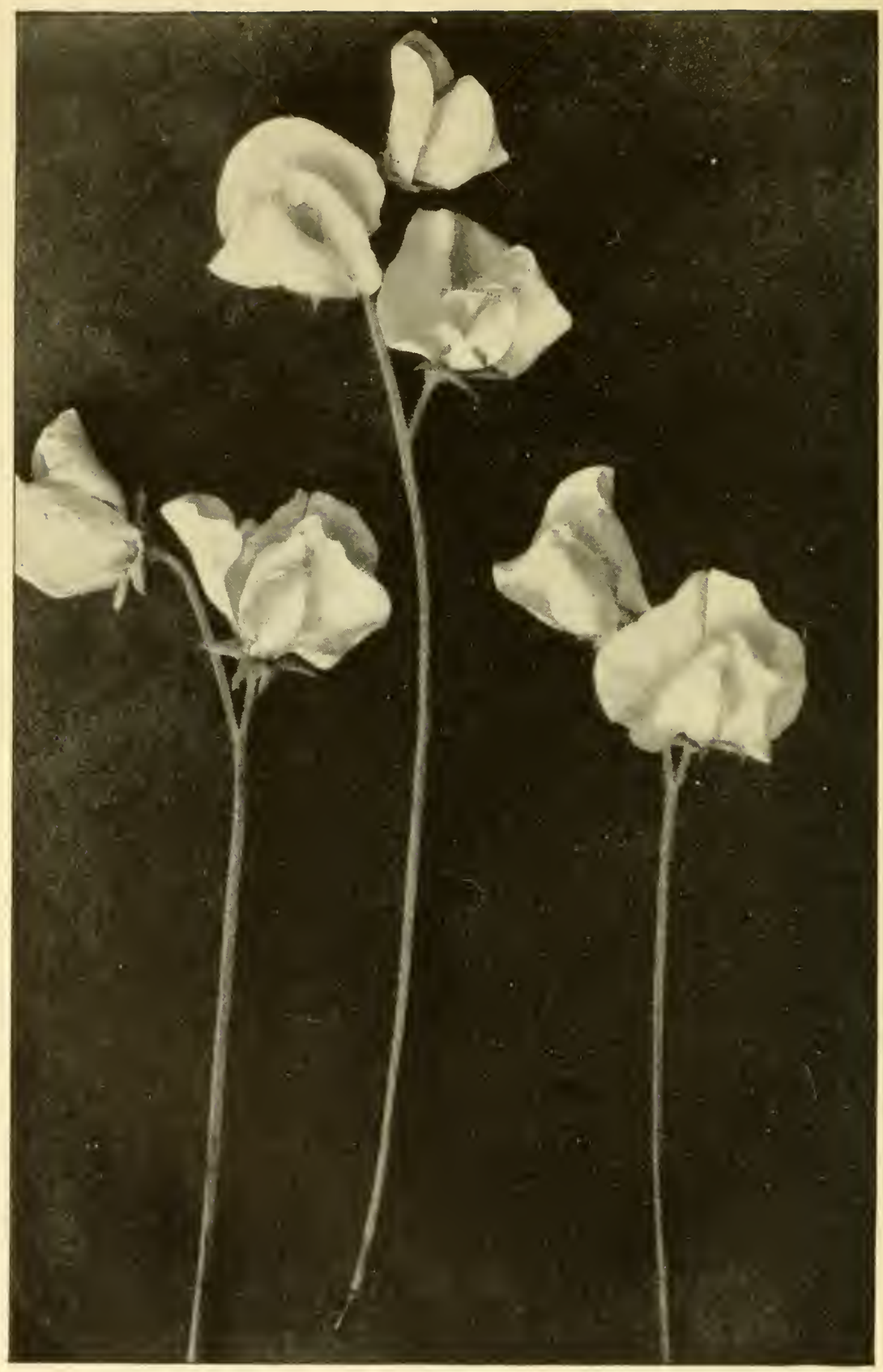

The winter-flowering sweet pea, Canary 


\title{
SWEET PEA STUDIES - II \\ WINTER-FLOWERING SWEET PEAS
}

\author{
Alvin C. Beal
}

Next in order to the waved section the most important type of sweet peas yet developed from the older garden forms is the winter-flowering class, which has reached its greatest perfection in the United States.

\section{DISTINGUISHING CHARACTERS}

The winter-flowering type is absolutely distinct in its habit of growth and its early-flowering character. Unlike the garden types, which apparently stand still for a time when only a few inches high while side shoots are developed, the winter-flowering peas grow rapidly until they attain a height of two to four feet; then they begin to flower freely, after which time side shoots are developed. In trials at this station the varieties of the winter-flowering type, planted September 24, came into flower between Thanksgiving and Christmas; while some varieties of the waved and the older types, planted at the same time, did not flower until the last week in April. Nany varieties of the first-named type were flowering freely at the holidays, but the record would have been surpassed had it not been for the fact that during the month of November the region about Ithaca had not an entire day of sunshine and had only two partly sunny days. December was almost as dark and cloudy.

The winter-flowering peas make their greatest growth under glass. When planted in the spring in the open ground they make a very slender growth as compared with the garden type, and flower early in the season when a few inches high. However, they flower very profusely and continuously.

The garden type stools out well when planted under glass, but requires the entire winter for growth if planted in the fall. It is said by a practical grower that seed planted in January will flower as soon as that planted in August. This difference in habit of growth, manifesting itself very early, is of great value to the florist in enabling him to guard against loss from procuring the wrong secd.

The flowers of the winter-flowering type are generally of the open form of Blanche Ferry. Some of the English- and American-raised varieties of this type are hooded, and Anton C. Zvolanek is perfecting a wavedflower group. At this station it is thought that the open-flowered type 
is superior in substance in midwinter, and the flowers remain open. This appears, therefore, to be the commercial type. The perfection of this type will be along the line of increased size and of number of flowers on a stem.

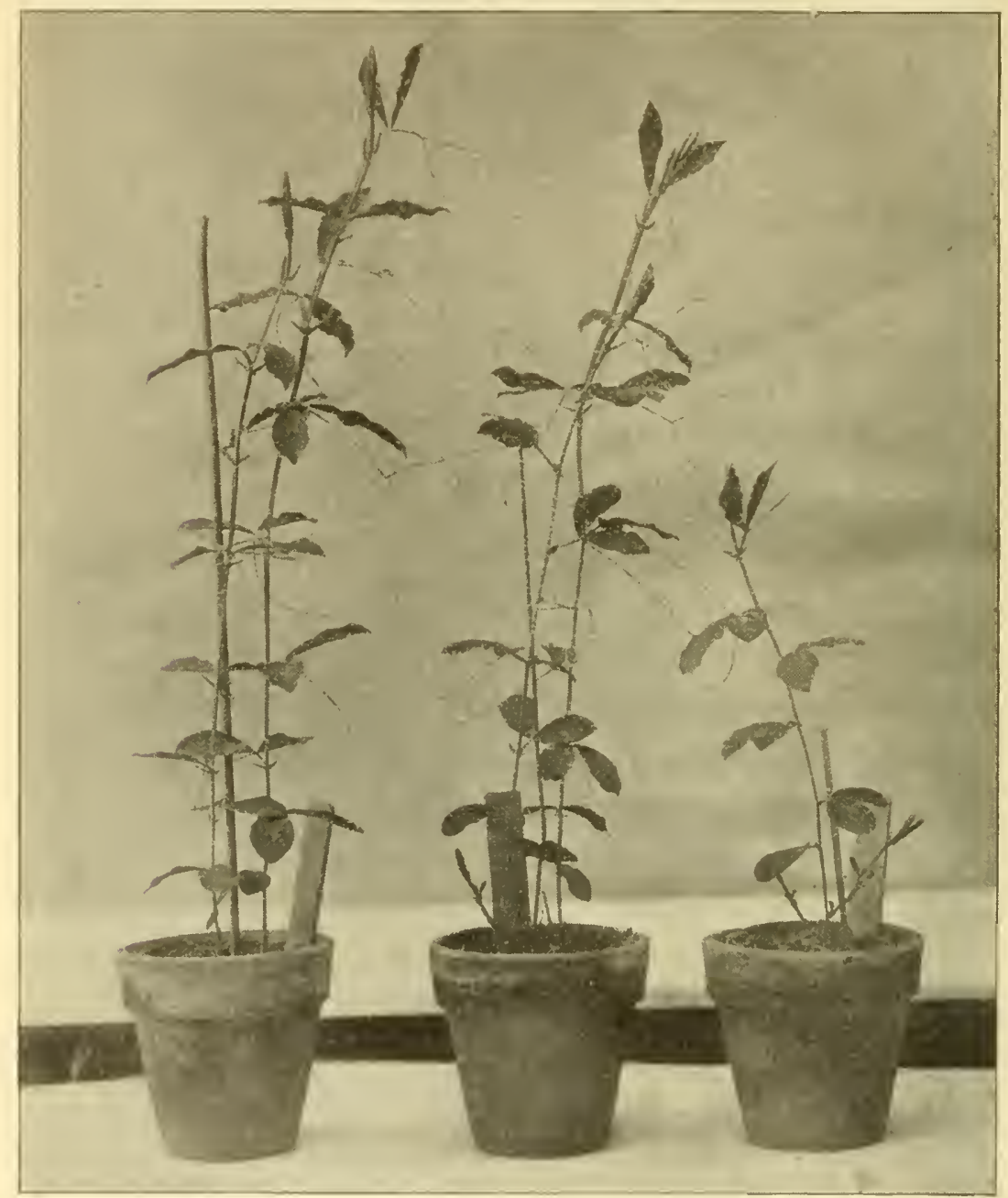

Wallacea

Counless of Rutn'r

FIG 171.-Difference in growuth of the winter-flmuering and garden types

The hooded varieties are often too much hooded and have, in the eyes of the buyer, a wilted appearance; or, even when they show their freshness, the flowers do not give the appearance of their real size, as is seen in Mrs. F. J. Dolansky. 


\section{FORCING SWEET PEAS}

Fifteen years ago sweet peas were usually fairly plentiful in the markets of the large cities about the first of April, and sometimes flowers were ieen as early as the last week in February. Among the varieties grown were Blanche Ferry, Lottie Eckford, Emily Henderson, and Katherine Tracy. The seeds were usually sown in August or September in pots and benched after chrysanthemums, or seeds were planted in carnation senches and the plants trained on the purlin supports of the greenhouse. William Scott advocated the above methods, especially the latter, as ie asserted that the plants did not make much growth until the bright spring days when there was sufficient sunshine for both carnations and ;weet peas.

Florists have been growing sweet peas under glass to a limited extent or a number of years. Soon after the introduction of Blanche Ferry, it least twenty years ago, this variety was tried under glass. The first ecord of sweet peas being grown under glass in any other than a very imited way is in I897, when, Mr. Zvolanek states, he grew three houses of them, thus becoming undoubtedly the largest grower in the country at that time. In March of that year, sweet peas, white and pink, were reported as very plentiful in the New York market, selling at first at twenty-five cents for a bunch of twelve sprays.

Previous to the introduction of the Zvolanek varieties in 1906 , besides the varieties above given, the following were grown: Emily Eckford, Golden Gleam, Countess of Radnor.

\section{LEADING TYPES}

\section{Christmas-flowering group}

This group of winter-flowering sweet peas was developed by Anton C. Zvolanek, now of Bound Brook, N. J., who doubtless supplied The Weekly Florists' Review with the following account of their origin, appearing in the issue of that periodical for April I3, I899, page 495:

\section{Sweet peas under glass}

"The accompanying engraving is from a photograph taken January 6 last, of a house of sweet peas at the establishment of Mr. Ant. C. Zvolanek, West Hoboken, N. J. The boxes seen in the picture are 6 inches wide and 6 inches deep. The seed was sown in these boxes, out of doors, September 2, and the boxes taken inside the last week in October. The plants began to bloom November 20 , and the first cut of 200 flowers was sent to market November 24. The house was $12 \times 73$ feet and built of sash containing $6 \times 8$-inch glass. The temperature given was 45 
degrees at night. From this house Mr. Zvolanck cut 20,400 blooms during the month of December and 38,800 during January, the stems I4 inches long.

"The varicty is one that originated with Mr. Zvolanek. Five years ago he noted among some Lottic Eckfords a plant that started flowering about two weeks earlier than the others and was dwarfer in habit. The following year he fertilized this with Blanche Ferry and the result was a decided improvement in color, size, stem, and habit. He named it Zvolanek's Christmas. He has five other houses of sweet peas, the seed having been sown outside in 4-inch pots early in September and the seedlings planted out in the solid beds inside in November and December in the same soil in which chrysanthemums had been growing. These seen to do as well as those in boxes, supplying a crop of flowers by Christmas."

The above account of the origin of this group is confirmed in a paper written by Mr. Zvolanek and published in Möller's " Deutsche GartnerZeitung," May 3, 1902. In that account he states that he discovered the original plants in January, I892, among Lottie Eckfords that did not usually flower until March. The following is his account:

" On January I, I 895 , I was able to send the first ten dozen cut blooms to New York, where they occasioned great surprise. In I899 I introduced this variety as Zvolanek's Christmas.

"Meanwhile I endeavored to secure other colors by crossing, in which I was also successful. In January, I 899 , I exhibited four new seedlings before the New York Florists' Club, and these were in the colors pure white, lavender, malnaison-colored, and red; all of which were commended. Especially prominent is the pure white, which was registered with the Society of American Florists December is, 1900, as Miss Florence E. Denzer and which will be sent out next August (1902). This excellent sort surpasses its mother, Zvolanck's Christmas, in the size of its flowers as well as in length of stem, producing over twenty per cent blooms with four flowers on very long stems."

There was found no record of the exhibit mentioned above, but the writer finds mentioned and illustrated in The American Florist for January 6, 1900 , the following new and promising varieties originated by Mr. Zvolanck:

"No. I has been named Zvolanek's Christmas; No. 2 is a seedling from Emily Henderson; No. 3, variegated seedling; No. 4, sport from Zvolanek's Christmas; No. 5, seedling from Katherine Tracy."

The New York F'lorists' Club, on January I 4 , I90I, awarded honorable mention to A. C. Zvolanek for a pink variety named Christmas and for two white varieties, No. 6 and Miss Florence E. Denzer. 
The parentage of the chref varieties of this group has been given by Mr. Zvolanek as follows:

Miss Florence E. Denzer - Christmas x Emily Henderson

Christmas Comtes - Improved Christmas x New Countess

Christmas Captain - Florence E. Denzer x Captain of the Blues

Miss Helen M. Gould - Florence E. Denzer x -

Mrs. Alexander Wallace - Florence E. Denzer x Lady Grizel Hamilton

Mrs. Edie Wild - Christmas Pink x Salopian

Secretary William J. Stewart - Christmas Captain x Countess Spencer Mrs. W. W. Smalley - Enchantress x Mrs. E. Wild

Mrs. William Sim - Christmas White x Mrs. E. Wild

Mrs. F. J. Dolansky - Seedling of Enchantress

Mrs. J. F. Hannan - Mrs. William Sim x Mrs. E. Wild

Miss Josie Reilly - Florence E. Denzer x Mrs. A. Wallace

Le Marquis - William J. Stewart x Gladys Unwin

Mrs. Charles H. Totty - Mrs. A. Wallace x blue unnamed seedling

Greenbrook - Mrs. George Lewis x unnamed seedling

Blue Bird - Walter Wright x Wallacea

Mrs. George Lewis - Watchung x Gladys Unwin

Mrs. Zvolanek - Helen Pierce x Christmas White

Governor Fort - Seedling of Mrs. William Sim x Spencer seedling

Mr. Zvolanek has probably originated over one hundred varieties, but of this number only the following thirty have been sent out:

Igoo, Christmas, or Christmas Pink.

1902, Miss Florence E. Denzer.

I 905, Christmas Red and Christmas White.

I906, Mrs. E. Wild and New Christmas Flowering Hybrids, mostly blue, salmon, and lavender.

1907, Le Marquis, Mrs. A. Wallace, Mrs. William J. Stewart, Mrs.

F. J. Dolansky, Jack Hunter, Christmas Captain, Mrs. Charles

H. Totty, Miss Josie Reilly, and Christmas Meteor.

I908, Mrs. W. W. Smalley, Mrs. George Lewis, Greenbrook, Miss

Helen M. Gould, and Marian Hannan (Mrs. J. F. Hannan). I909, Wallacea, Governor Fort, Pink Beauty, Mrs. Zvolanek, Helen

Keller, and Snow Queen.

ı го, Blue Bird, Zvolanek's Blue, Zvolanek's Orange, Zvolanek's Pink.

\section{Télemly group}

The Télemly varieties of sweet peas have been offered in England for sowing under glass. So far as the writer can learn, they have not yet been offered or grown by the trade in this country. 
This group was originated by the Reverend Edwyn Arkwright, in his garden at 'Télemly, on the hill of Mustapha near the city of Algiers, in Algeria, Africa. For a number of years our great American varicty, Blanche Ferry, was grown. This variety has always been known as an carly variety, and it flowered about the end of March in the locality mentioned.

The Reverend Mr. Arkwright, in an article in the Sweet Pea Annual for 1907 , says:

"About seven years ago a sport showed itself in my garden as early as February and was promptly isolated from all others. 'The next year I had some plants flowering in January, and among them one red one, a cross apparently from Mars, on which a blossom or two had come out in May of the previous year. From these parents I have now ten or twelve of the usual colours, ranging from white to purple, and including duplicates, or shall I say imitations, of Honorable Mrs. E. Kenyon, Jeannie Gordon, Lady Grizel Hamilton, Mars, Black Knight, etc., which begin to flower about Christmas time and last for five months.

"That they form a distinct group is evident from the fact that Eckford's sweet peas, which I sow at the same time, i. $c$., at the end of September, do not flower till May. Moreover, the leaf is considerably narrower than in Eckford's varieties and more pointed and the stem appears to have more woody fibre."

\section{Engclmann group (Lathyrus odoratus Praccox)}

Another group of winter-flowering sweet peas has been offered by C. Engelmann, of Saffron Walden, Essex, England. Mr. Engelmann says, in the Sweet Pea Annual for 1907 :

"It is nearly four years since some plants of Captain of the Blues sported with me and gave winter-flowering varieties of quite distinct habit. Ordinarily stocks sown in attumn will not bloom under glass until the following April, but the newcomers commence to bloom from six to ten wecks after seed sowing, and continue to form branches and produce flowers all through the winter.

"I have now winter-flowering representatives of such varicties as Dorothy Ecliford, Lady Grizel Hamilton, and Miss Wilmott, as well as a number of crosses between these and the ordinary type and Mont Blanc, so that almost all sweet pea colours are represented.

"In 1906 I sowed my winter-flowering varieties at the end of August and beginning of September, and the resulting plants commenced to flower in October and wore splendidly in bloom at the end of November and carly in December, and they slould continue to flower until the ordinary sweet peas come into flower.' 


\section{Blanche Ferry and its descendants}

The following is quoted from an article by Will W. Tracy, in The American Florist, Vol. I3, April 2, ISg8:

"Some forty years ago a woman in northern New York noticed and saved seed from a particularly bright-flowered plant of the Painted Lady. She planted them in her garden, and each succeeding year saved and planted seeds from what she thought were her best plants. She did not raise many, some years not more than a dozen plants and never more than could be grown in three square beds. She was the wife of a quarryman and her garden was always over limestone ledges where the soil, though fertile, was often not over a foot in depth, anil gradually her plants became more compact and sturdy, until after some ten or twelve years she ceased to bush them, simply letting them. support themselves. After she had raised them in this way for some twenty-five years a seedsman noticed their beauty, obtained about one hundred seeds, and from them has come the Blanche Ferry."

This variety was introduced by D. M. Ferry \& Co. in I 889 . In their catalog for that year it is shown by means of a colored plate.

Peter Henderson \& Co. introduced in $\mathrm{I}_{9} 93$ the famous

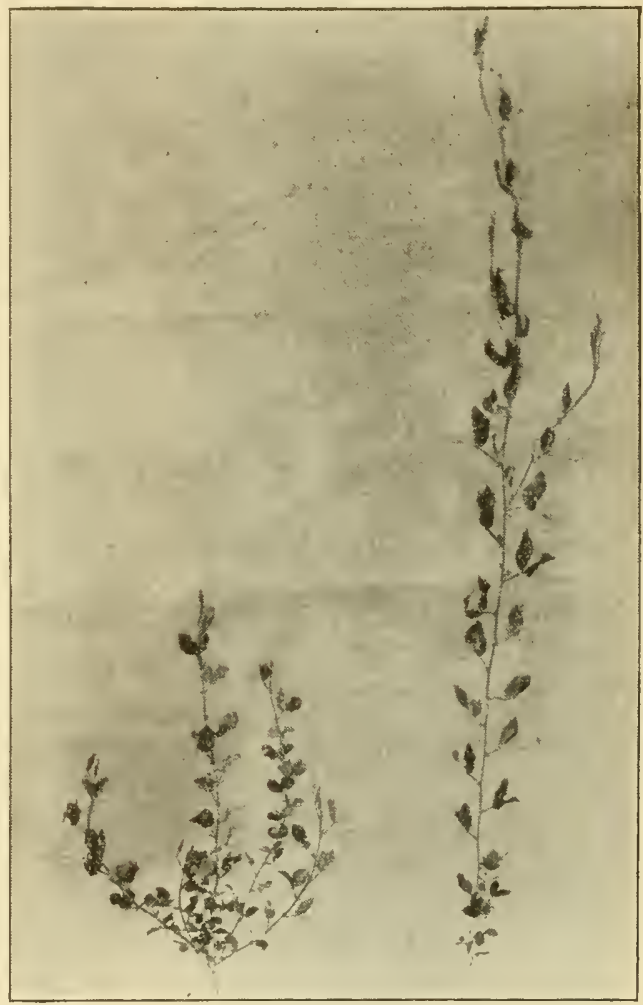

FiG. I72.-Branching of the plants of the garden and winter-flowering types

white variety, Emily Henderson, a sport of Blanche Ferry. In 1895 D. M. Ferry \& Co. sent out Extra Early Blanche Ferry, which they produced in $\mathrm{I} 892$.

Earliest of All was distributed in $I \$ 98$ by Burpee. In his catalog he says that "it is not only the earliest to bloom in the open ground, but also the most desirable for forcing under glass for winter cut flowers. The dwarf habit of the plant (only two feet) renders it much more easily 
grown upon benches, admits of closer planting, and from seed sown in the latter part of August blooms may be cut for the holidays, while with the taller varieties no blooms could be ent before February or March." In 1902 the firm sent ont an earlier strain of this variety under the name "Gould's Extreme Early Earliest of All."

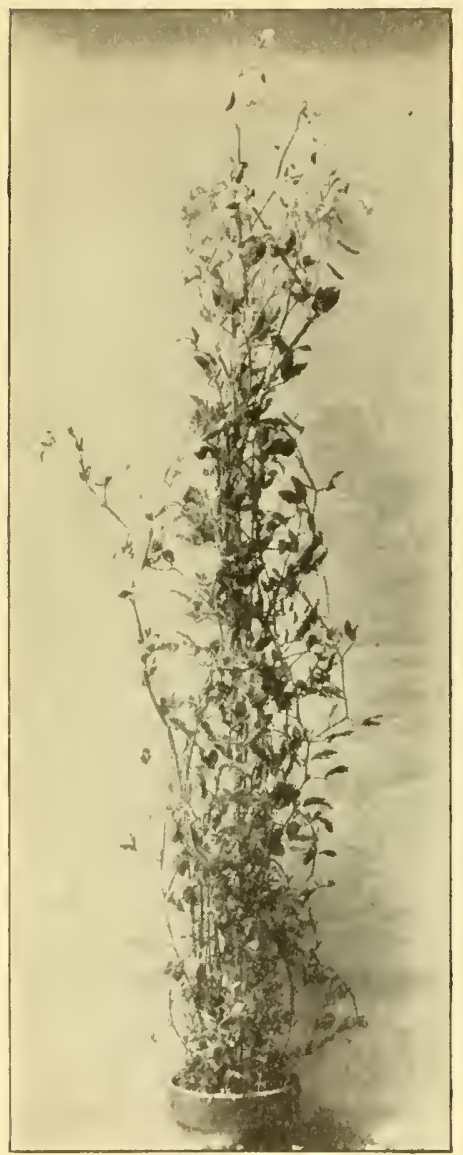

FiG. 173.- Sweet peas grown in pots

Mont Blanc was introduced by Ernest Benary, of Erfurt, Germany, in 1900 . It is said that this variety came from Emily Henderson. Burpee, in his catalog for 1901 , says that it is the exact counterpart of Earliest of All except in the color of the flowers, which are white.

Earliest Sunbeams appeared in 1904 and was described as a primrose Mont Blane, with which it was identical except in color.

In 1904 Mr. Thomas Gould, of California, the originator of the strains of Earliest of All, found a white sport in a stock of the Reselected Earliest of All, which was identical with Earliest of All in every respect except color. Unlike Mont Blanc, it had a black seed. This variety, Earliest White, was introduced in 1906 by Burpee, who strongly recommended it for forcing.

Thus we had in 1906 a group of earlyflowering varieties represented by Blanche Ferry, Extra Early Blanche Ferry, Earliest of All, Extreme Early Earliest of All, Mont Blanc, Earliest Sunbeams, and Earliest White, which were of distinct habit from the usual garden types and which were sometimes forced under glass. These varieties were all descendants of Blanche Ferry, from which they originated as seed sports either directly or indirectly. A further significant fact is that Blanche Ferry is a descendant of Painted Lady, which is the connmon name of the sweet pea described by Burmann in 1737 as a new species from Ceylon.

The known origin of the winter-flowering type of the Zvolanek and Télemly strains indicates their relation to Blanche Ferry, and this is confirmed by the fact that Watchung, Florence E. Denzer, and others are indistinguishable from varieties named above. 
CULTURE UNDER GLASS

\section{The house}

Winter-flowering sweet peas grow six to ten or more feet high, and if they are to attain their full development a house with this amount of headroom is required. They also need all the light they can get, as the lighter the house, the more blooms there will be. Low or dark houses are not practicable.

Solid beds. - Sweet peas may be grown on benches, but solid beds are better since the plants require a deep, moist, cool soil. The roots should be given an opportunity to go down, by properly preparing the soil two or three feet in depth. With this depth of prepared soil it is imperative that the beds have good drainage, for oversaturation is detrimental to the young plants and any tendency to keep them in this state brings on sourness, which is fatal to sweet peas. Having the beds raised at least one foot above the walks will assist in keeping the soil uniformly sweet.

When planning to grow sweet peas under glass in solid beds, the house should be cleared as early as possible. Trench the soil two feet deep. If the beds have been manured annually, the bottom soil may be brought to the surface. In new houses, in case the beds are to be raised a foot, trench the soil cighteen to twenty-four inches deep if it is a good loam; if not, remove the soil and fill the beds with good soil. This gives an additional foot of loosened soil when the bed is full, but it is needed for additional drainage. In turning this original soil in a new bed, apply a heavy coat of good decomposed cow manure in the trench. Then spread on top a three-inch coat of manure and fill in with the preparcel soil. In the old beds, put a three-inch layer of manure in the bottom of the trench and another about a foot below the top. The soil should remain thus until about the time for sowing; if a month or more intervenes, it is much better. At this time fork over the top layer one foot deep, which mixes the upper layer of manure with the surface soil.

Benches. - While good crops of sweet peas may be grown on benches, yet they require more care than when in beds. The swect pea is frequently grown as a crop to succeed chrysanthemums, particularly by those florists who do not devote a great amount of space to pot plants. In order to have flowers for Christmas, the early chrysanthemums should be cleared from the house by October 20 and the space filled with good sweet pea plants transplanted from pots.

\section{The seed}

Only good, strong-germinating seed should be used, and the best for the purpose is the outdoor-grown stock of this type. If the grower raises his own seed for the earliest planting, that from outdoor fall-sown plants 
is preferable; otherwise it will always pay to purchase stock from the specialists who produce seed under California conditions. Seed procured near the end of the season from exhausted greenhouse-grown plants often germinates poorly or produces weak plants. Sometimes, even though the seedlings start off fairly well, they later exhibit constitutional weakness.

If the steam pipes are on the side walls, plant the first row of seeds five feet from them. If the rows $m$ n east and west, plant the others five feet apart; if the rows run north and south, space them three feet apart. Make the drills one or sne and a half inch deep, and drop the sceds one to one and a half mch apart. Cover the depth of the drill, and keep the surface level.

\section{Sowing}

The winter-flowering varieties may be sown in the beds or benches where they are to stand, or they may be sown in pots. The former method gives the better results. * A day or two before planting, the beds should be thoroughly saturated with water; William Sim, the most extensive grower, advises a strong dose of liquid manure instead. As soon as the top has dried off so as to be in a good friable condition, plant the seed. The varicties with white seeds are best sown in sand; or, as Mr. Zvolanek advises, soak the seeds for ten hours in water, scatter in flats, and allow to remain for two days or until the seeds begin to swell. The seeds may then be sown in moderately dry soil in the same way as other varieties. The white-seeded varieties, more than any others, require careful attention in the watering.

\section{Watering}

If the soil has been saturated before planting, no more water should be applied for perhaps a week, or only when the soil is no longer moist three inches below the surface. When a thorough watering is not applicd first, and the seed is sown and watered in, as a rule not enough water is given to saturate the soil very deep. The result is that the plant confines its root area to this shallow moist layer and does not root decply. It thereforesuffers from extremes, and any lack of moisture is followed by a check from which it never recovers. On the other hand, if the preparatory watering is given and water withheld until there is need of it, the roots strike downward into moist and cooler soil where they overcome, as far as possible, the effects of the hot days. The sweet pea must be kept growing steadily from the day the seed is sown. When water is needed, do not apply near the plants, but between the rows, where it should be given liberally. This treatment is especially important with

\footnotetext{
* One large grower sows the seed in flats or benches, in sand, transplanting the seedlings as soon as the upper side root is one half inch long. Two plants are placed in each two-and-a-half-inch pot. These are planted, four pots to one foot of row, in the greenhouse.
} 


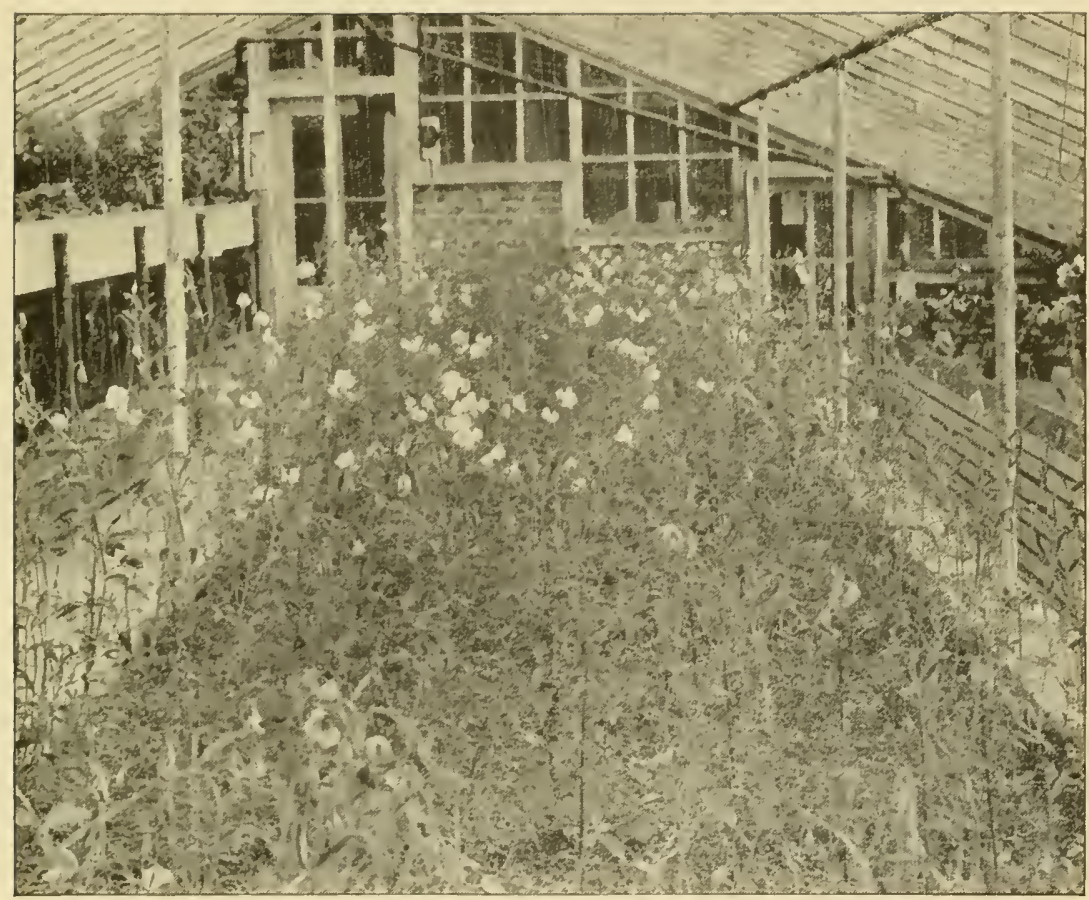

The house of winter-flowering sweet peas, February, 1910 

the early plantings. One reason why water should not be applied too near the plants is that they are especially subject to damping off. This trouble becomes more prevalent in October and November, when there are more cloudy days, cool nights, and like conditions. Because of this, no soil should be heaped around the stem.

\section{Time to plant}

When a good crop of sweet peas is desired for Christmas, the seed should be sown the 2oth of August. When sown September I the plants will flower in January; when sown September I $_{5}$ the main crop will be in February; and when sown in October the crop will be ready in March. November sowings flower in the latter part of March; December sowings in April; January sowings in April and May; February sowings from May I on; and a March sowing in May or June. This gives the time when a reasonable crop can be expected, although flowers will be cut, especially with certain varieties, in a shorter interval than that given.

Some of the varieties in the tests at this station, sown October 20 and benched December 20, gave flowers during the last week in January, but not freely until about March. Some sown November 20 and benched December 20 began flowering in February and gave an abundance in March. Seed sown in beds September 24 this year gave flowers on Thanksgiving Day, although during the whole month of November there was not one clear day and there were only two partly clear days.

\section{Supports}

As soon as the peas are up, a support must be furnished. This may consist of string, wire and string, or wire netting. When string is used it is stretched lengthwise on each side of the row and fastened to stakes on the purlin posts. The wire-and-string support consists of wires stretched over the row, one near the ground and another eight to ten feet above it; between these, string is stretched lengthwise every ten inches, and perpendicular strings connect the top and bottom wires.

Wire netting is condemned by commercial growers. They maintain that the vines do not cling to it, so that just as much tying is needed; and, besides, more crooked stems occur than when the vines are trained o. string. At this station, however, all the methods have been tried and the wire netting has been found preferable.

\section{Temperature}

Keep the temperature in the early stage as low as possible, giving full ventilation, day and night, as late as possible without freezing. The 
cooler the plants can be kept while growing, the stronger and healthier they will be. In this way the natural outdoor spring conditions are approximated.

When the flower buds can be felt in the tips of the growing stems, the temperature should be raised $\mathrm{I}^{\circ}$ a night until $50^{\circ}$ is attained, which is the proper temperature during December, January, and February. From about the end of February on, a night temperature of $48^{\circ}$ is better. On bright days a rise of $10^{\circ}$ or even $15^{\circ}$ may be given. On cloudy days $55^{\circ}$ is high enough, for higher temperatures promote soft, succulent growth that wilts when the sun comes out. Plenty of rentilation should be provided at every opportunity, as this, with careful regulation of temperature, causes a firm growth.

\section{Insects}

Sweet peas are especially subject to attack by the red spider, but unless the plants are too near heated pipes such attacks do not often occur except in the fall months. The careful use of water after the plants have attained a height of a few inches will eradicate this pest.

The common enemy of greenhouse plants, the grcen fly, attacks sweet peas from the time they appear above ground. These insects can soon destroy the young plants, as well as weaken the plants at any stage. Fumigation should be attended to carefully, the grower choosing cool nights or performing the work early in the morning; the chief object bcing to clear the plants thoroughly by regular and persistent fumigation so that they will not need fumigating when in bloom, as the odor is objectionable and injures the sale of the flowers. Tobaceo also bleaches the flowers of some varieties. In the spring, when spraying plants with nicotine for green fly or for thrips, use this insecticide carcfully as sweet peas arc subject to injury from it. A nicotine preparation containjing forty per cent of the constituent nicotine, used at the rate of two teaspoonfuls to cach gallon of water, will kill the thrips that are hit by the spray.

Climbing cutworms and snails, if present in greenhouses, will destroy sweet peas. The former insects, which attack also carnations, violets, and chrysanthemums under glass, are combated by using compost that has not been covered by a rank growth of weeds and grass. When their work is noticed a scarch should be made for the worms under any mulch or lumps of earth on the bench, where they are coiled up during the day. They may also be picked from the plants at night while feeding. The use of poisoned baits is also recommended; among the best of these is the bran-arsenic mash, made by mixing one part white arsenic, one part sugar, and six parts bran, with sufficient water to form a mash. This may be placed among the plants. Snails can be controlled by the application of lime and soot to the surface of the beds or benches. 


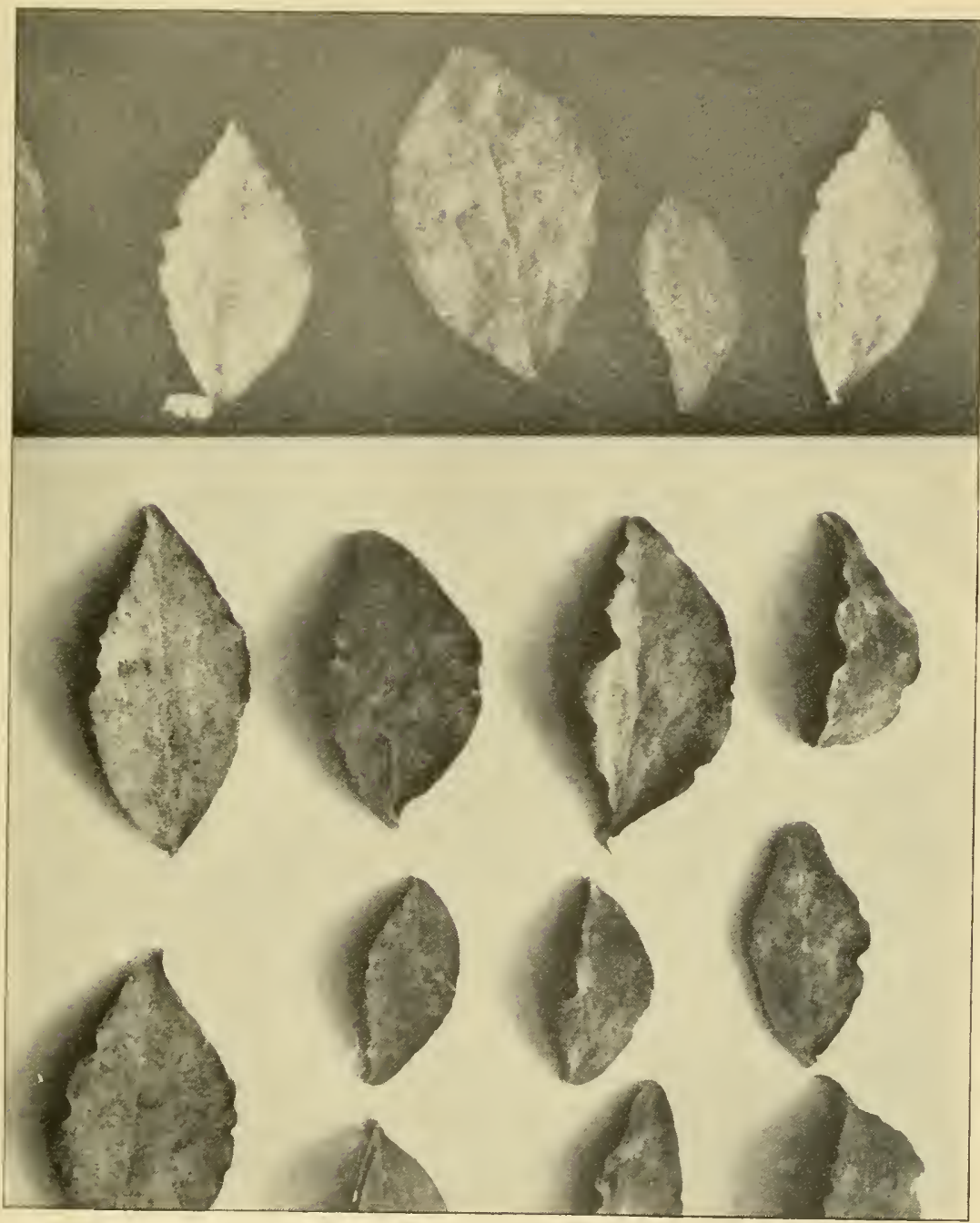

The sweet pea mildew 



\section{Diseases}

The damping-off fungus has already been mentioned as causing the loss of young plants. Sometimes plants are seen with whitc- or yellowstreaked foliage. From experience at this station it appears that such a condition may follow the use of any soil that is not sweet. An instance occurred when a mold growing over the ashes of a bench entered the bottom of some pots of peas, causing the soil to become stale and musty. All the plants where this occurred showed streaked foliage later. The disease is undoubtedly physiological in its nature and is thought by practical growers to occur sometimes from the use of too much or too fresh manure on young plants.

The dropping of flower buds is often a cause of complaint from growers. The first flower buds frequently do not set on vigorous, thrifty plants. Usually this condition soon disappears, but sometimes it is necessary to keep the plants a little dry and to abstain from the use of fertilizers until the plants are blooming freely. The loss of the buds will follow a sudden fall in the temperature or will result from overwatering. Another cause is, growing the plants in too cool an atmosphere. Plants that are grown in the proper temperature, with careful attention to watering, ventilation, and fceding, do not fail to give an abundance of flowers.

Mildew sometimes attacks sweet peas during the autumn, unless the temperature and ventilation receive attention. It has been found at this station that mildew yields readily to applications of sulfur to the pipes, and to the use of flour of sulfur dusted on the infected leaves. As soon as the fires are started in the fall, some sulfur should be applied to the pipes as a preventive. This should be used judiciously, however, for an interesting case came under observation at this station during the past winter, of the danger of using sulfur too strong. An application had been made, and on a very cold night the pipe covered with the sulfur was turned on, the result being that every flower which was well advanced or open was scorched so that most of the flowers had to be thrown away. No injury to the plants occurred.

\section{TESTS OF WINTER-FLOWERING SWEET PEAS AT CORNELL UNIVERSITY}

The origin of the various groups of winter-flowering varietics of sweet peas has been traced above, and the varieties of the garden type formerly grown under glass have been noted.

All obtainable varieties of the winter-flowering type have been grown two seasons under glass, and also out of doors during the past summer.

From Anton C. Zvolanek, Bound Brook, N. J., were received original winter-flowering sweet pea seeds of the following thirty-one varieties: 
Bhue Bird, Christmas Captain, Christmas Pink, Enchantress, Florence E. Denzer, Governor Fort, Greenbrook, Jack Hunter, Le Marquis, Metcor, Míss Helen M. Gould, Miss Josie Reilly, Mrs. C. H. Totty, Mrs. F. J. 1)olansky, Mrs. J. F. Hannan, Mrs. George Lewis, Mrs. A. Wallace, Mrs. E. Wild, Mrs. William Sim, Mrs. W. W. Smalley, Niger, Pink Beauty, Red Seedling, Variegated, Watchung, William J. Stewart, and Wallacea; in inг I, Zvolanek's Blue, Orange, Pink, and J. K. Allen.

From C. Engelmann, Saffron Walden, Essex, England, came the following six varieties of Lathyrus odoratus Praccox: White, Mauve, Deep Mauve, Carmine, Maroon, and Bluc.

There were obtaincd from F. Flectwood Paul, Botley, Hants, England, the following four varietics of "Paul's Improved Télemly Strain, or Christmas-Flowering Sweet Pcas": Rose and Carmine, Mauve, 'Two Shades Pink, and White.

From the Reverend E. Arkwright, Télemly, Alger-Mustapha, Algeria, Africa, were received the following eighteen named varictics of Télemly sweet peas: Apple Blossom, Indigo Blue, Bluc and Red, Cerise, Lavender and Pink, Lavender; Maroon, Mauve, Pale Pink, Pink, Pale Primrose, Purple, Purple and Maroon, Red Bicolor, Red Sclf, Red and White, Violet, and White.

Canary, Flamingo, Christmas White, Snowbird, and Mrs. A. C. Zvolanek, also seeds of Mont Blanc, Earliest Sumbeams, Earliest White, Earliest of All, Reselected Earliest of All, Emily Henderson, and Blanche Ferry, were received from A. T. Boddington, New York. The same fim forwarded packets of their stock of Florence E. Denzer, Mrs. W. W. Smalley, Mrs. A. Wallace, Mrs. William Sim, Mrs. E. Wild, Mrs. George Lewis, Christmas Pink, and Watchung, which were identical with the varicties of the same name in the Zvolanek collection.

The Bryson Ayres Company, Independence, Mo., sent the following varictics: Christmas Primrose, Mrs. A. Wallace, Ayres' Thanlisgiving White, Christmas Blue, Mrs. C. H. Totty, Christmas Pink, Mrs. William Sim.

Altogether, seventy-three varieties, from five sources in Amcrica, Algcria, and England, have been tested at this station. This probably represents the largest collection of the forcing type ever brought together. In all these trials there has never been discovered the slightest reason for believing that any rariety was a hybrid between some species of the retch and Lathyrus odoratus. Side by side with the varieties of winter-flowering sweet peas the following species of vetch have been grown and studied at all stages of development: I'icia sativa, I. aillosa, I. gerardii, and I'. fulgens.

The winter-flowering Lathyrus odoratus Praccox and the Télemly strains all have the same habit of growth and carly-flowering propensity, with 


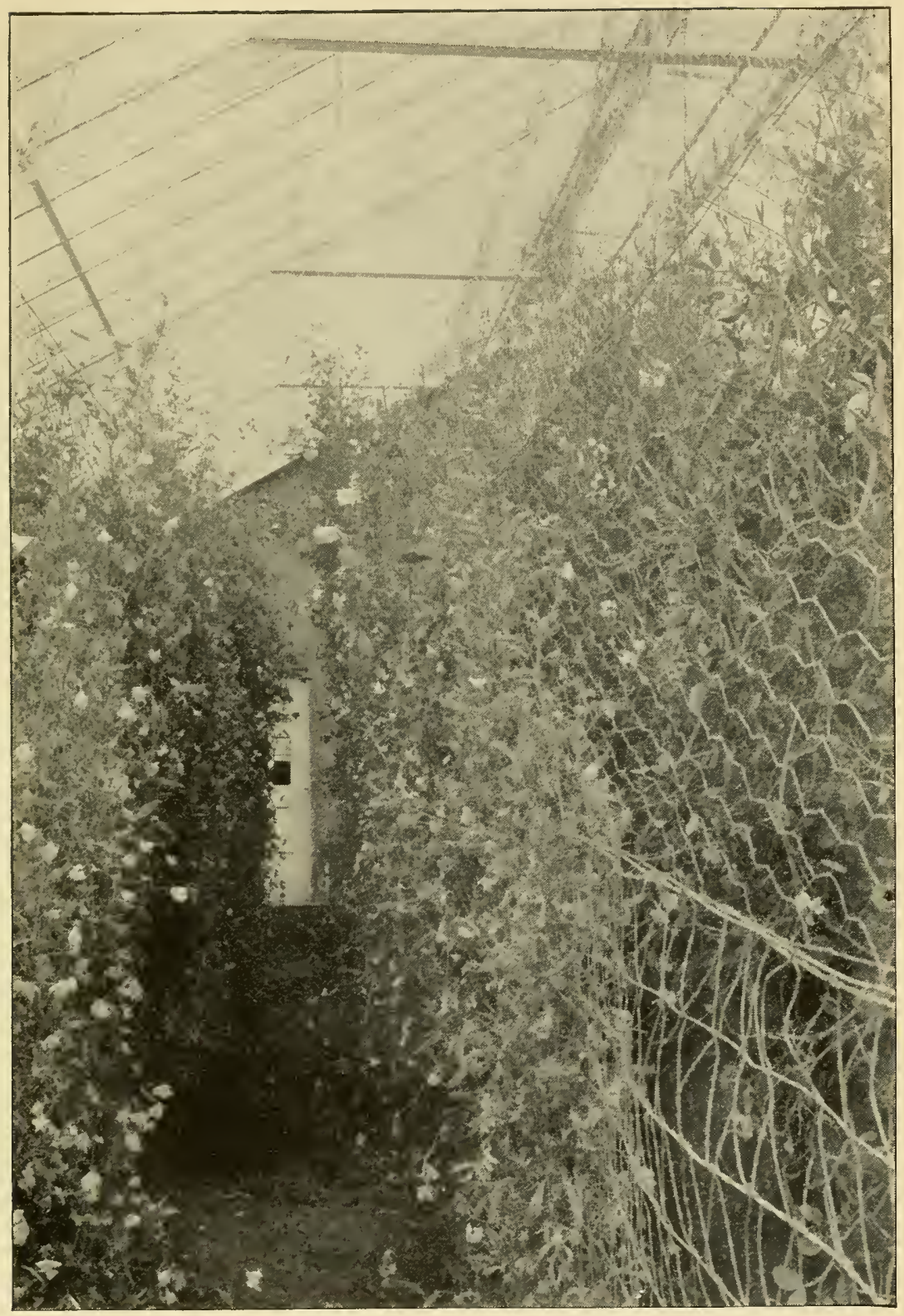

The winter-flowering sweet peas, May 3, I9II. After blooming for five months 



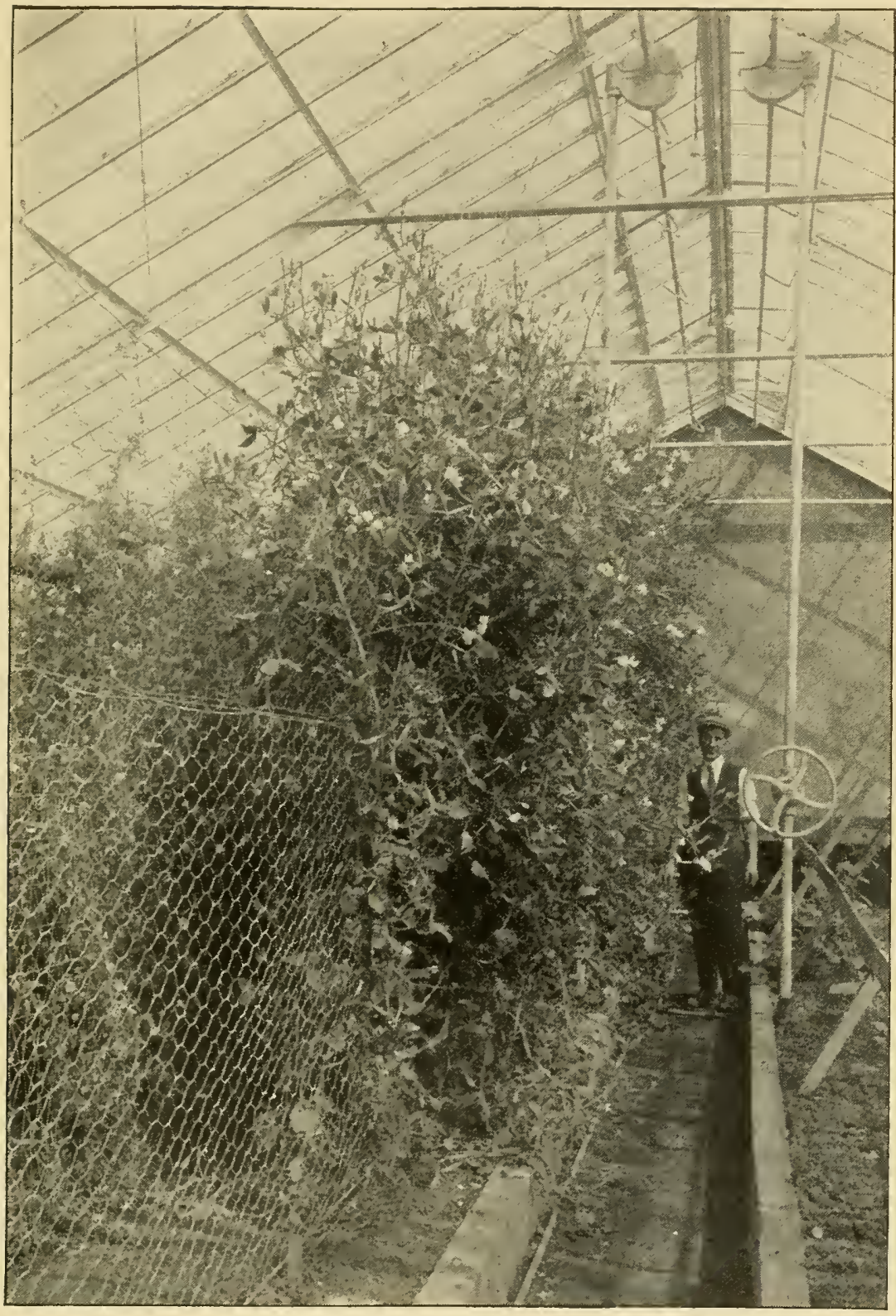

The Spencer sweet peas, May 4, IOII. A few days after beginning to bloom 

the exception of Paul's Télemly Mauve, which is distinct from Arkwright's Télemly Mauve and which belongs to the outdoor type since it exhibits similar characteristics of bushy growth and is late-flowering. This variety, planted at the same time as the other varieties from Mr. Paul, produced flowers eight to nine weeks later; the second year it gave flowers seventeen to eighteen weeks later.

The Télemly varieties from Arkwright show by the form of their flowers that they have been derived from Blanche Ferry. The latter, when sown in August, does not flower much in winter, although it has much the same character of growth.

The varieties Florence E. Denzer and Mont Blanc, also Earliest White, Watchung, and Snowbird, and Christmas Pink, Earliest of All, Reselected Earliest of All, and Blanche Ferry, have flowers that are identical and the three last named come into bloom at the same time. The open-flowered varieties from Zvolanek and Boddington are carlier than the hooded varieties and are also less vigorous growers.

NUMBER OF DAYS REQUIRED TO BRING INTO BLOOM

Earliest White.

Earliest of All.

Watchung .

Snowbird

Reselected Earliest of A11.

Blanche Ferry..

Earliest Sunbeams

Two Shades Pink.

Blue Bird.

Greenbrook

Christmas Pink

Mont Blane

Canary.

Télemly Palc Primrose

Christmas Captain

Variegated.

William J. Stewart.

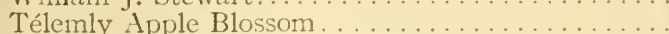

Télemly Naroon

Le Marquis

Christmas Meteor.

Mrs. Zrolanek.

Télemly Pink

Mrs. J. F. Hannan.

Helen M. Gould

Télemly Indigo Blue

Variety

Planited in pots

October 22

(1909-

1910)

\section{Planted} in open ground (1910)
Planted

in beds

Septem-

ber 24

(1910-

I9I I)

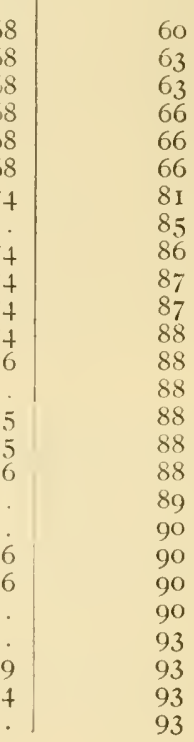




\begin{tabular}{|c|c|c|c|}
\hline Varicty & $\begin{array}{c}\text { Planted } \\
\text { in pots } \\
\text { October } 22 \\
\text { (1909- } \\
\text { 1910) }\end{array}$ & $\begin{array}{l}\text { Planted } \\
\text { in open } \\
\text { ground } \\
\text { (1910) }\end{array}$ & $\begin{array}{l}\text { Planted } \\
\text { in beds } \\
\text { Septem- } \\
\text { ber } 24 \\
\text { (1910- } \\
\text { I9II) }\end{array}$ \\
\hline Télemly Blue and Red. & 91 & & 93 \\
\hline Christmas Enchantress. & 97 & 77 & 94 \\
\hline Mrs. C. H. Totty. & 106 & 76 & 94 \\
\hline Mrs. A. Wallace. & 106 & 77 & 94 \\
\hline Paul's Rose and Carmine. ................... & 104 & . . & 94 \\
\hline Christmas White. . . . . . . . . . . . . . . & 99 & & 94 \\
\hline$\ldots \ldots \ldots \ldots \ldots$ & 101 & 77 & 94 \\
\hline Flamingo $\ldots \ldots \ldots \ldots \ldots \ldots \ldots \ldots \ldots \ldots \ldots \ldots \ldots$ & 95 & 74 & 9.5 \\
\hline Arkwright's Télemly White................. & 94 & & 95 \\
\hline Télemly Purple. ........................ & 93 & & 95 \\
\hline Florence E. Denzer. . . . . . . . . . . . . . . & 105 & 74 & $9^{6}$ \\
\hline Niger $\ldots \ldots \ldots \ldots \ldots \ldots \ldots \ldots \ldots \ldots \ldots \ldots \ldots \ldots \ldots$ & 104 & 78 & 95 \\
\hline 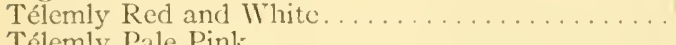 & 92 & & 96 \\
\hline Télemly Pale Pink. ....................... & 92 & & 96 \\
\hline Pink Beauty $\ldots \ldots \ldots \ldots \ldots \ldots \ldots \ldots \ldots \ldots \ldots \ldots \ldots \ldots \ldots$ & 101 & 74 & 96 \\
\hline Red Seedling. . . . . . . . . . . . . . . . . . & 103 & 74 & 96 \\
\hline Télemly Violet. . . . . . . . . . . . . . . . . & 98 & & $9^{8}$ \\
\hline Télemly Cerise...$\ldots \ldots \ldots \ldots \ldots \ldots \ldots \ldots \ldots$ & 98 & $\ldots$ & 102 \\
\hline $\begin{array}{l}\text { Jack Hunter } \\
\text { MIiss Josie Reilly . . . . } \ldots \ldots \ldots \ldots \ldots \ldots \ldots \ldots \ldots \ldots\end{array}$ & 97 & it & 101 \\
\hline $\begin{array}{l}\text { Miss Josic Reilly . . . . . } \\
\text { Praecox White........ }\end{array}$ & 99 & 79 & IOI \\
\hline $\begin{array}{l}\text { Praecox White........ } \\
\text { Mrs. 1 . I. Dolansky... }\end{array}$ & 105 & & IOI \\
\hline $\begin{array}{l}\text { Mrs. 1. J. Dolansky . . } \\
\text { Mrs. William Sim }\end{array}$ & 101 & 77 & 102 \\
\hline $\begin{array}{l}\text { Mrs. William Sim .... } \\
\text { Mrs. WV. W. Smalley. . }\end{array}$ & 103 & 76 & 102 \\
\hline $\begin{array}{l}\text { Mrs. WV. W. Smalley. } \\
\text { Télemly Red Self. .... }\end{array}$ & 102 & 78 & 102 \\
\hline $\begin{array}{l}\text { Télemly Red Self. } \\
\text { Télemly Lavender }\end{array}$ & 98 & $\ldots$ & 102 \\
\hline $\begin{array}{l}\text { Télemly Lavender and Pink. . } \\
\text { Télemly Mauve (Arkwright).. }\end{array}$ & 93 & . & 102 \\
\hline $\begin{array}{l}\text { Télemly Mauve (Arkwright) . } \\
\text { Télemly Lavender. . . . . . . . . }\end{array}$ & 95 & . & 107 \\
\hline $\begin{array}{l}\text { Télemly Lavender. } \\
\text { Governor Fort... }\end{array}$ & 101 & & 107 \\
\hline $\begin{array}{l}\text { Governor Fort... } \\
\text { Praceox Carmine. }\end{array}$ & 99 & 78 & 109 \\
\hline $\begin{array}{l}\text { Praceox Carmine. } \\
\text { Praecox Deep Maui }\end{array}$ & 111 & . & 110 \\
\hline $\begin{array}{l}\text { Praecox Deep Mau } \\
\text { Mrs. E. Wild.... }\end{array}$ & 109 & & 110 \\
\hline $\begin{array}{l}\text { Mrs. E. Wild. . . . } \\
\text { Praceox Mauve... }\end{array}$ & $I(O)$ & 81 & II 2 \\
\hline $\begin{array}{l}\text { Praecox Mauve........ } \\
\text { Paul's Télemly Mauve }\end{array}$ & 107 & & 124 \\
\hline $\begin{array}{l}\text { Paul's Télemly Mauve } \\
\text { Mrs. George Lewis... }\end{array}$ & 160 & & 218 \\
\hline $\begin{array}{l}\text { Mrs. George Len } \\
\text { Paul's Télemly II }\end{array}$ & 94) & 76 & 96 \\
\hline Paul's Télemly I & 94 & & 102 \\
\hline
\end{tabular}

The garden varieties tested 1910-1911

Emily Henderson

The gurden warieties tested ig

Henry Eckford.

King Edward VII

Countess Spencer

Helen Lewis.

Primrose Spencer.

White Spencer.

The plants of the garden type started September $2+$ with the winterflowering type produced their first blossoms during the last week in 
April, while the latter were still blooming freely after having yielded cut blooms for nearly five months, and the extra early varieties for six months.

NUMBER OF DAYS COMING INTO BLOOM CLASSIFIED ACCORDING TO GROUP TO WHICH THE VARIETIES BELONG

\begin{tabular}{l|l|l}
\hline Variety & I909-1910 & I9I0-I9II \\
\hline
\end{tabular}

Engelmann varieties - Lathyrus odoratus Praecox

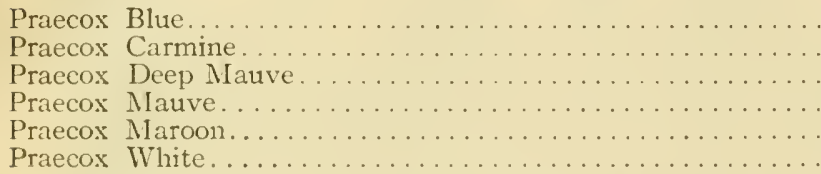

\begin{tabular}{|c|c|}
\hline I I I & \\
\hline I 11 & I IO \\
\hline 109 & 110 \\
\hline 107 & I 24 \\
\hline 109 & $\cdots$ \\
\hline 105 & IOI \\
\hline
\end{tabular}

Paul's Improzed Tclemly rarieties

Two Shades Pink. .............................

\begin{tabular}{r|r}
92 & 85 \\
104 & 94 \\
160 & 218 \\
94 & 102
\end{tabular}

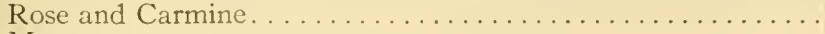

Mauve

White

Arkwright's Tilemly zarieties

Télemly White

Télemly Pale Primrose.

93

93

Télemly Apple Blossom. . . . . . . . . . . . . . . . . . . . . . . . . . . . .

Télemly Pink.

Télemly Indigo Blue

Télemly Blue and Red

Télemly Purple.

Télemly Red and White

Télemly Pale Pink

Télemly Violet.

Télemly Cerise

Télemly Lavender and Pinls.

Télemly Mauve. .

Télemly Lavender.

Télemly Red Self.

Télemly Red Bicolor

Télemly Purple and Maroon.

\section{DESCRIPTIONS OF VARIETIES}

In the following descriptions of winter-flowering sweet peas and such other kinds as are used for forcing, the varieties are classified according to the form of the standard into two groups - open and hooded. Each group is subdivided into its leading colors by the marginal divisions. The white varieties are arranged in groups according to color of the seedwhite seed and black seed. The year given is that in which the variety was introduced. The Répertoire de Couleurs was used as the standard chart in determining the colors of the flowers. 


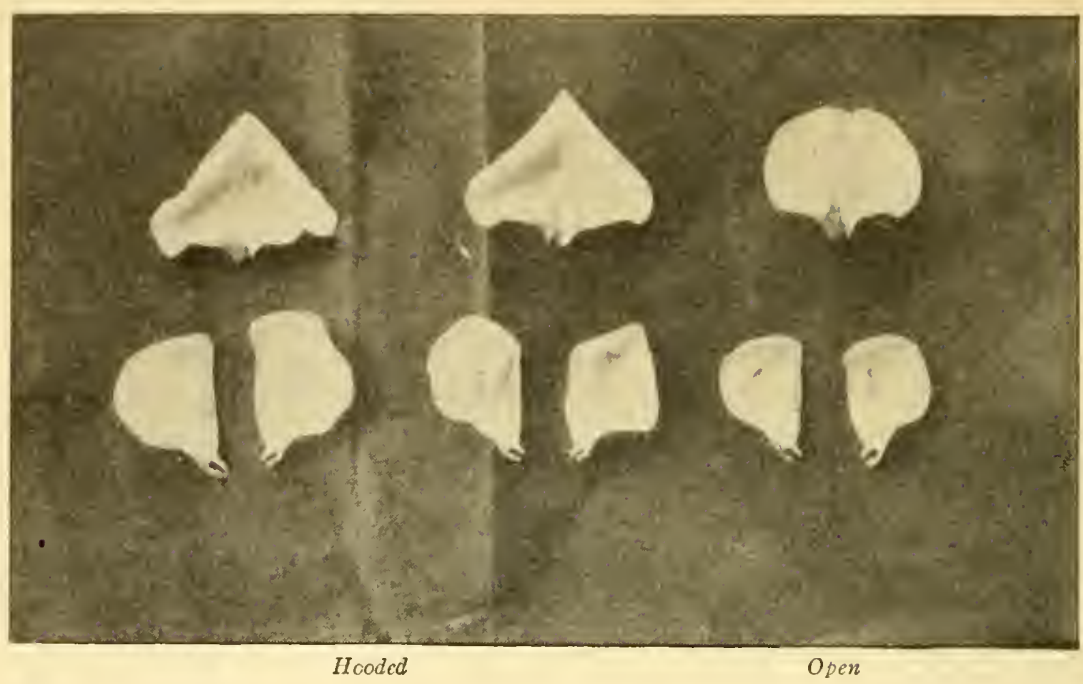

Fig. 174.-Classification according to the form of the flower

OPEN FORM

\section{CHRISTMAS WHITE}

White (White seed)

Originated by Zvolanek, I905.

Donated by Boddington.

Description in brief - Medium size, white, open-form, notched standard, dwarf growth.

Synonym - This is Florence E. Denzer.

\section{FLORENCE E. DENZER}

Originated by Zvolanek, I 902.

Donated by Zvolanek, Boddington.

Description in brief - Medium size, pure white, open-form, notched standard, dwarf growth, medium early. Valuable for market.

Description in detail - Color snow-white I-4 (2), the expanding flowers greenish white I-2 (I5). Open-form, flat, notched standard, long, narrow wings. Flowers two or three on stems of medium length, of good substance and fragrant. Plant dwarf, not orer six feet. Sced white. Said to be a cross between Christmas Pink and Emily Henderson in I895. Registered as Miss Florence E. Denzer, December I 5 , 1902 .

Comparison - This variety is a month later than Watchung, Snowbird, and Earliest White. In the open it was a week later.

Synonym - Christmas White is the same variety. 


\section{MONT BLANC}

Originated by Bernary, I900.

Donated by Boddington.

Description in brief--Mediun size, pure white, open-form, notched standard, midseason, dwarf growth.

Comparison - Similar to Florence E. Denzer.

\section{TÉLEMLY WHITE}

Originated by

Donated by Paul.

Description in brief - Medium size, pure white, notched standard, midseason variety of dwarf growth.

Remark - This variety has white seeds and germinated very poorly, giving two plants from ten seeds.

Comparison - Similar to Florence E. Denzer.

\section{TÉLEMLY WHITE}

Originated by Arkwright.

Donated by Arkwright.

Description in brief - Large size, pure white, open-form, notched standard, midseason variety, of tall, vigorous growth.

Remark - This white contains a variety of hooded form similar to Dorothy Eckford.

Comparison - During both seasons this variety was distinctly larger than any other white variety.

\section{EARLIEST WHITE}

White (Black seed)

Originated by Gould. Sent out by Burpee, I 906. Donated by Boddington. Description in brief - Medium size, pure white, notched standard, dwarf growth. Valuable because of its extreme earliness.

Description in detail - Fully open flower milk-white 2-3 (I I); wings and standard have no trace of color except in the young bud. Open-form, flat, notched standard, wings long and broad. Flowers one to three on short medium stems, substance good, fragrant. An early and free bloomer. Plant dwarf, under six feet, begins to bloom when eighteen inches high. Leaflets dark green, narrow, and pointed. Seed large, round, and black.

Remark - Both seasons, under glass, this variety and its synonyms were three weeks earlier than any other variety, and in the open ground they were one week earlier than Mont Blanc.

Comparison - This variety is similar to Snowbird and Watchung. 


\section{SNOWBIRD}

Originated by

Donated by' Boddington.

Description in brief - Medium size, pure white, open-form, notched standard, dwarf growth. Valuable for carly forcing.

Comparison - Similar to Earliest White and Watchung.

\section{WATCHUNG}

Originated by Zvolanek, 1907.

Donated by Zvolanek, Boddington. Description in brief - Medium size, pure white, open-form, notched standard, dwarf growth. Valuable for carly forcing.

Comparison - Very similar to Earliest White.

\section{Primrose}

\section{CANARY}

Originated by

Donated by Boddington.

Description in brief - Medium size, primrose, open-form, notched standard, early variety.

Description in detail - Color of opening standard is cream-yellow 2 (30), fades to creamy white 2 ( 10 ); wings yellowish white 3 (I 3 ), fading to creamy white I (г). Flower open-form, with flat, notched standard, wings long, broad, and concealing the keel. Growth not tall, under six fect.

Comparison - Opens deeper yellow and not quite so large as Burpee's Earliest Sunbeams and Télemly Primrose. Standard erect and flat, while those of the last-named variety often reflex on the edges. Plant grew taller than other primrose varicties.

\section{EARLIEST SUNBEAMS}

Originated by Burpee, 1904.

Donated by Boddington.

Description in brief - Medium size, primrose, open-form, notched standard, dwarf growth, carly variety.

Description in detail - Color yellowish white $\mathrm{I}-2$ ( $\mathrm{I} 3$ ), black deeper shade, wings slightly lighter. Open-form, notched standard, long, broad wings. Flowers one to three on medium stems, substance good, moderately fragrant. Early and free bloomer. Plant not tall, under six fect. Leaflets dark green, narrow, and pointed. Seed white.

Comparison - This varicty is similar to Télemly Pale Primrose, and was introduced prior to it.

\section{TÉLEMLY PALE PRIMROSE}

Originated by Arkwright.

Donated by Arliwright. Description in brief - Medium size, open-form, primrose, notched standard. carly variety.

Comparison - Similar to Earliest Sunbeams. 


\section{Pink}

\section{TÉLEMLY PINK}

Originated by Arkwright.

Donated by Arkwright.

Description in brief - Bright pink, medium size, open-form, notched standard, moderately vigorous grower, midseason.

Description in detail - Color of the standard as it opens is bright purplerose $2-3$ ( 150 ) or Rose Neyron red I (I I9), changing to pale lilac-rose 2 (I 30); wings mauve-rose I ( I 53). Flower open-form, notched standard, with large, long, broad wings. Stems long and strong. Fragrant. Midseason. Plant a moderate grower.

Remark - One of the most beautiful pink varieties in the collection. but is not fixed.

\section{ZVOLANEK'S PINK}

Originated by Zvolanek, I 9 Iо.

Donated by Zvolanek.

Description in brief - A large, open, soft pink flower.

Description in detail - Color of standard Rose Neyron red I-2 (I I9); wings lilac-rose I $\left(\mathrm{I}_{52}\right)$ or paler. Flower large, open-form, and borne on stems of medium length and strength. Fragrance moderate. Good substance. Plant medium height, slender, but a very profuse bloomer.

\section{Cream pink}

\section{MRS. W. W. SMALLEY}

Originated by Zvolanek, I9o8.

Donated by Zvolanek, Boddington. Description in brief - Medium size, soft pink, open-form, late variety. Description in detail-Color of the standard, rosy flesh I (I34); wings pale flesh I (I36). Flower medium size, open-form standard sometimes with a faint notch, flat; wings long and narrow, concealing the keel. Season late. Plant a moderately vigorous grower, medium height.

Comparison - A Christmas or winter-flowering open-form Venus. Registered with the Society of American Florists, March, I 906.

\section{Bicolor}

\section{TÉLEMLY APPLE BLOSSOM}

Originated by Arkwright.

Donated by Arkwright.

Description in brief-Medium size, open-form, flushed pink on light primrose standard, wings light primrose. An early variety.

Description in detail - Color milk-white 4 (II), standard flushed with pink $4(7)$, in the center with milk-white edges. Wings milk-white. Variable in color and in size. Open-form, notched standard, wings large, long, and broad. Flowers on medium long stems, fragrant. Productive. Plant dwarf, under six feet, slender growth. Leaflets narrow and pointed. 
Remark - Fully one half rogues, one with a red standard and pink wings, the other an inferior variety with purple standard and blue wings.

\section{CHRISTMAS PINK}

Originated by Zrolanck, 1899 .

Donated by Zvolanek, Boddington. Description in brief - Medium size, red and white, open-form, early variety. Very valuable market variety grown under glass.

Description in detail - Under glass, color of standard is deep cerise 4 ( 123 ), wings are lilacy white I ( 7 ). Open-form standard notched, wings long and broad, concealing the kcel. Flowers two to three on long, strong stems. Very productive.

Remark - This variety under glass was three weeks later than Earliest of All and other varietics, and in the open ground was one week later. Comparison-Similar in color to Blanche Ferry, Earliest of All, and others, but much superior to these varietics in cvery respect except in earliness.

\section{BLANCHE FERRY}

Introduced by Ferry, I $8 S 9$.

Donated by Boddington.

Description in brief - Medium size, red and white, extra early, open-form, notched standard, short stems, plant a poor grower in midwinter.

Remarks - An old forcing variety, but superseded by Christmas Pink. Not productive from November to March, and stems too short.

\section{EARLIEST OF ALL}

Originated by Gould. Sent out by Burpee, 1898 . Donated by Boddington. Description in brief - Medium size, red and white, open-form, notched standard, extra early variety.

Remark - This varicty was in every respect similar to Blanche Ferry and Reselected Earliest of All.

Comparison - Similar in color to Christmas Pink and Télcmly Red and White, but much earlier. Not equal to those varictics for growing under glass in midwinter.

\section{RESELECTED EARLIEST OF ALL}

Introduced by Gould. Sent out by Burpce, I902. Donated by Burpee. Descripiion in brief - Medium size, red and white, open-form, notched standard, short stens, extra early, plant a weak grower under glass. Comparison - One year of trial under glass showed that this varjety was not so vigorous as, and was no carlier than, Earlicst of All. In the open ground this variety came into bloom on the same day as Blanche Ferry and Earliest of All. 


\section{TÉLEMLY RED AND WHITE}

Originated by Arkwright.

Donated by Arkwright.

Description in brief - Medium size, open-form, red and white, notched standard, productive, midseason, very vigorous variety.

Description in detail - Flower open-form, flat, notched standard, wings long and broad, concealing the keel. Flowers two to three on very long, strong stems. Very productive. Plant tall, vigorous grower, over ten feet.

Comparison - Similar to Christmas Pink.

\section{TÉLEMLY. PALE PINK}

Originated by Arkwright.

Donated by Arkwright.

Description in brief - Medium size, pink standard and primrose wings, open-form, strong grower.

Description in detail - Color of standard mauve rose I (I53); wings lilacy white $3(7)$. Flower open-form, notched standard, medium size, wings long and broad, concealing the keel. Flowers medium size, two and three on long, strong stems, fragrant. Nidseason. Plant vigorous, tall, over eight feet. Leaflets narrow, pointed, and very dark green.

Comparison - Superior to Télemly Apple Blossom, as it has larger flowers, is a stronger grower, and is a pure stock. Is distinct from that variety, however.

\section{Crimson and Scarlet}

\section{CHRISTMAS METEOR}

Originated by Zvolanck, 1907 .

Donated by Zvolanek.

Description in brief - Medium size, red, open-form, notched standard, midseason, dwarf grower.

Description in detail-Color of standard crimson-red I (I I4), wings rosy magenta I (I69) changing to magenta 2 (IS2). Flowers openform, medium size, short stems. Standard notched at the top and with narrow base; wings long and broad, hooded, concealing the keel. Productive. Continuous bloomer. Midseason. Plant moderately tall grower, six feet. Under glass was a fixed variety.

Comparison-Distinct from Flamingo. Télemly Red Bicolor has a similar flower, but is later. Meteor is winter-flowering Ignea. In the open ground the flower blackens as does that variety, and the same rogue occurs in it.

Registered with the Society of American Florists, February, I9o6.

\section{TÉLEMLY RED SELF}

Originated by Arkwright.

Donated by Arkwright.

Description in brief - Medium size, red, open-form, notched standard, late. 
Comparison - Similar to Christmas Meteor, but in the experiments at this station it was later-flowering.

\section{TÉLEMLY TWO SHADES PINK}

Originated by

Donated by Paul.

Description - This variety was so badly mixed that it was absolutely impossible to determine the true variety. The best thing in it was a red similar to Metcor, and so the variety has been included here There was no other with two shades of color cxcept a few plants of Blue and Red Télemly, and one plant of Red and White Télemly. The majority of the plants produced flowers of a lilacy white or faint blush pink, but of very inferior form.

\section{TÉLEMLY RED BICOLOR}

Originated by Arkwright.

Donated by' Arkwright. Description in brief - Medium size, red bicolor, open-form, notehed standard.

Description in detail - See Télenly Rose and Carmine.

\section{TÉLEMLY ROSE AND CARMINE}

Originatcd by

Donated by Paul.

Description in bricf - Small to medium size, red, open-form, midseason variety.

Description in detail - Standard carmine lalie 2 (I 2 I), and wings rosy magenta 2 ( 169 ). Flower open-form, notched standard, wings long and narrow, hooded. Variable in size, upper flowers on the spike are noticeably smaller. Stems long. Midseason.

Comparison - This is similar to Arliwright's Télemly Red Bicolor.

\section{Rose and Carmine}

\section{CHRISTMAS RED}

Originated by

Remark - Mr. William Sim (in Horticulture, Vol. VII, No. I9, May 9, I008, p. 628) says that this variety is identical with Flamingo.

\section{FLAMINGO}

Originated by

Donated by Boddington. Description in bricf - Medium size, red, open-form, midseason variety of short growth. 
Description in detail-Color crimson-red I (II4), fading to $3^{-4}$ (II8); wings rosy magenta I-2 (I69), changing to magenta 4 (I82). Flower open-form, notched in top of standard, the edges of which reflex; wings spreading, slightly hooded at tips. Flowers likely to run below medium size. Stems short. Little or no fragrance. A productive midseason variety. Plant of short growth, under six feet, with narrow, pointed leaflets. A pure stock.

\section{Cerise}

\section{TÉLEMLY CERISE}

Originated by Arkwright.

Donated by Arkwright.

Description in brief - A medium-sized, red variety.

Description in detail - Color is far from cerise, being in these experiments a solferino red I (I57) on the standard, wings bishop's violet I (I89). Flower open-form, notched standard and small size. Season late. Plant a moderate grower.

Purity - Badly mixed, with one half the plants Télemly Mauve, Télemly Pale Pink, and Télemly Pink.

\section{Lavender}

\section{TÉLEMLY LAVENDER}

Originated by Arkwright.

Description in brief - A medium-sized, lavender variety.

Description in detail - Color of standard heliotrope I (I88) and of wings heliotrope I (198). Flowers medium size. Standard flat, notched. Season medium to late. Not a vigorous variety here.

\section{LAVENDER AND PINK}

Originated by Arkwright.

Donated by Arkwright. Descrption in brief - Medium size, lavender, open-form, late variety. Description in detail-Color of the standard lilac-rose I ( $\left.15_{2}\right)$ fading to lilacy white I (7), leaving the base lavender-blue; wings lavenderblue I (204), fading to almost white. Flowers medium size, open-form. Standard flat, notched. Wings long and broad. Season late. Plant a medium grower.

Purity - Contains Red and White, also Purple and Maroon.

\section{Mauve}

\section{TÉLEMLY MAUVE}

Originated by Arkwright.

Donated by Arkwright.

Description in brief - Medium size, mauve, open-form, late variety. 
Description in detail-Color of the opening standard bright violet 4 (198), changing to heliotrope I ( 88 ); wings open bright violet I (198), change to Parma violet I (200). Flower open-form, faintly notched, flat standard; wings long and broad. Flowers medium size, on long stems. Pragrant. Profuse bloomer. Plant very vigorous grower, over eight feet.

Purity - Contains a hooded form, also an early-flowering, waved, blush pink.

Comparison - Can be called an open-form Mrs. Alexander Wallace. Differs from that variety in the open form, deeper violet in the opening flowers, and deeper blue of the wings.

\section{TÉLEMLY MAROON}

\section{Maroon}

Originated by Arkwright.

Donated by Arkwright.

Description in bricf-Medium size, maroon, open-form, midseason, strong-growing variety.

Description in detail - The color is not found in the Répertoire de Couleurs; that of the standard is nearest 4 ( 172 ), but the wings are slightly purplish near 2 ( $\left.18_{5}\right)$ and the keel is shaded bishop's violet $+(189)$ on white. The effect is the color popularly called maroon. Flower open-form, notched standard, size medium. Stems long. . Plant a vigorous grower.

Comparison - Distinct from Praecox Maroon.

\section{Striped}

\section{MISS HELEN M. GOULD}

Originated by Zvolanck, 1908 .

Donated by Zvolanek.

Description in brief - Medium size, red stripe, open-form, midscason, short grower.

Description in detail - Striped and flaked with lilacy white I (7) to pale light lilae I (187) on white ground. Wings creamy white 4 (10), fading to whitc. Flower open-form, notched standard, wings long and narrow. Flowers medium size on short to medium stems. Plant a short grower, under six feet.

Comparison - Of Earliest White type.

\section{VARIEGATED}

Originated by Zvolanck.

Donated by Zvolanek.

Jescription in brief-Medium size, red stripe on white, open-form, carly varicty. 
Description in detail - Standard heavily striped and flaked lilac-purple 4 ( 160 ) on white; wings fleshy white I (9). Flowers open-form, medium size, on short stems. Standard notched at the top, with narrow base. Plant a short grower, under six feet. Leaflets narrow, pointed, and very dark green.

Comparison - This is Mrs. Zvolanek, 1909.

\section{MRS. ZVOLANEK}

Originated by Zvolanek, I 909 .

Donated by Boddington.

Description in brief - Medium size, red striped on white, open-form, carly variety.

Remark - This variety was grown in 1910-1911; catalogued as a Blue Variegated.

Comparison - This variety was received under the name "Variegated" in 1909 .

\section{Violet and Purple}

\section{CHRISTMAS CAPTAIN}

Originated by Zvolanek, 1907.

Donated by Zvolanek.

Description in brief - Above medium size, maroon-red standard and blue wings, open-form, early variety.

Description in detail - Color of standard plum-violet 2 (172) or vinous mauve 4 (I 4 ), with veins of darker color; wings light bluish violet I (202). Flower open-form, standard with notched top, reflexed edges, and narrow base, wings long and narrow, concealing the keel; size above medium, on medium long stems. Fragrant, very productive and carly. Plant a moderate grower, seven feet. Leaflets narrow and pointed.

Purity - Stock is unfixed. In open ground it broke up into six varicties. Said to be impossible to fix.

\section{TÉLEMLY BLUE AND RED}

Originated by Arkwright.

Donated by Arkwright.

Description in brief - Medium size or slightly larger, maroon-red standard and blue wings, open-form, midseason variety.

Description in detail - Opening standard deep carmine-violet 3 (I74), veins and midrib rich pansy-violet 4 (I91). The standard changes to a deep purple I (I 84 ). The wings open violet-purple I (I92), veins 4 (I92), change to light bluish violet I (202). Flowers open-form, medium size or slightly larger. Standard slightly notched, flat; wings long, hooded, concealing the keel.

Comparison - Somewhat on the order of Christmas Captain, but has brighter standards and is a fixed strain. 


\section{TÉLEMLY PURPLE AND MAROON}

Originated by Arkwright.

Donated by Arkwright.

Description in bricf - Medium size, maroon-red with dark blue wings, open-form, early variety.

Description in detail - Color of the standard is nearest to plum-violet $3(172)$, but is brighter; wings near 4 (194), or bluer.

Comparison - The standard is similar in color to the standard of Blue and Red Télemly, but the wings are dark blue, instead of light blue as in that variety.

\section{HOODED FORMI}

\section{MRS GEORGE LEWIS}

White (White seed)

Originated by Zvolanek, 1 go 8.

Donated by Zvolanek, Boddington. Description in brief - Medium to large, pure white, slightly hooded, moderate grower.

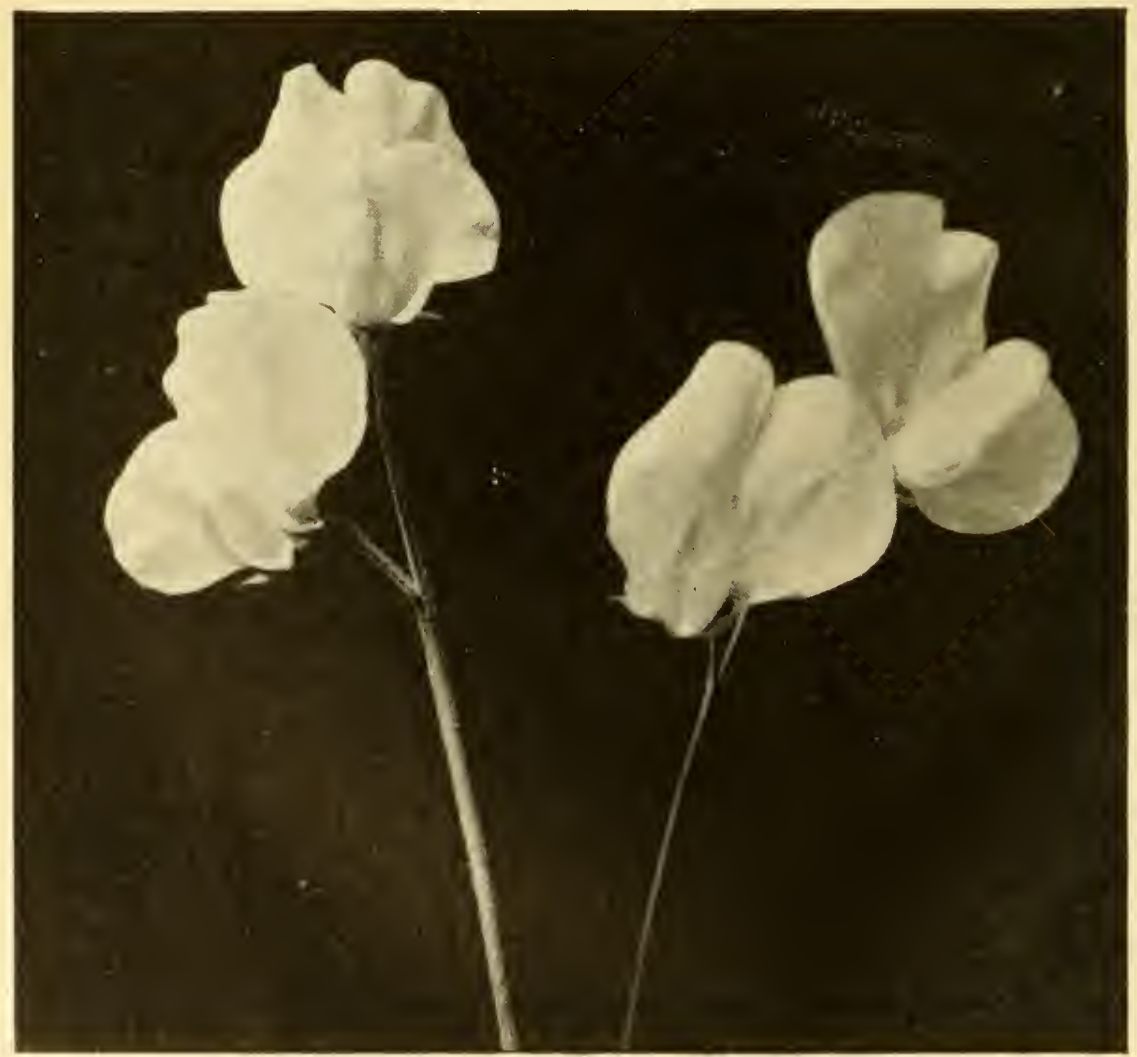

F1G. 175.-The white-flowerng sweet pea, Mrs. George Lewrs 
Description in detail-Color snow-white 1 (2), slightly hooded form, some flowers approaching the waved form. Standard round, no notch, wings long and narrow. Flowers one to three on medium stems, substance under glass not equal to Watchung. Very mildly and sweetly perfumed. Plant of moderate growth. Leaflets narrow and pointed. Seeds white, a large number split, and one of the most difficult kinds to germinate. Must be carefully handled.

\section{PRAECOX WHITE}

Originated by Engelmann.

Donated by Engelmann.

Description in brief - Medium-sized flower, late, white, extremely hooded, very long, strong stem, tall grower.

Description in detail - Flower extremely hooded, wings long and broad, concealing the keel. Moderately fragrant. Flowers three, medium size, on very long, strong stems. Profuse bloomer. Plant very vigorous grower, nine feet, with broad leaves. Seed white, but germinated well.

Comparison - A distinct variety.

\section{Primrose}

\section{JACK HUNTER}

Originated by Zrolanek, igos.

Donated by Zvolanek.

Description in bricf - Medium size, dwarf growth, late. Color salmonpink, hooded.

Description in detail - Color under glass, pale pink + (135) wings. Much hooded so that top of standard appears pointed, wings long and broad, concealing the keel. Flowers medium size, on long stems. Substance good. Free bloomer, and fragrant. Plant short, under six feet. Leaflets narrow, pointed, and very dark green in color. Seed black. Comparison - Appears to be Christmas-flowering Stella Morse. Registered with the Society of American Florists, February, I 906.

\section{Pink}

\section{MRS. F. J. DOLANSKY}

Originated by. Zrolanek, 1907 .

Donated by Zvolanel.

Description in brief - Light pink self, extremely hooded, strong grower, late variety.

Description in detail - Color in midwinter light rose I (128), but later is mauve-rose 2 (153). Flower is extremely hooded, making apparent size smaller than the real. Stems of medium length. Plant tall grower, over seven feet, narrow, pointed leaflets. A true stock. 
Comparison - This variety is superior to Christmas Enchantress. Is Christmas-flowering Prima Donna.

Registered with the Society of American Florists, April, I906.

\section{CHRISTMAS ENCHANTRESS}

Originated by Zvolanck.

Donated by Zvolanck. Description in brief - Light pink self, extremely hooded type, dwarf growth, midseason.

Description in detail-Color matwe-rose I (153). Extremely hooded form, giving standard a pointed appearance and reducing flower below medium size. Shows too many side notches. Free bloomer, with medium stems, fragrant. Plant dwarf grower, five feet. Leaflets narrow and pointed.

Comparison - Inferior to Mrs. F. J. Dolansky. Is Christmas-flowering Blushing Beauty.

Registered with the Society of American Florists, February, I go6.

\section{J. K. ALLEN}

Originated by Zvolanck.

Donated by Zrolanek.

Description in bricf - A large pink flower.

Description in detail - Color of standard violet-rose $\mathrm{I}-4$ ( $\left.\mathrm{I}_{54}\right)$; wings lilac-white, suffused with lilac-rose $\mathrm{I}-3(7)$. Flower large, hooded, and borne on stems of medium length and strength. Fragrance moderate. Substance good. Plant medium height and moderately productive.

\section{Cream Pink}

\section{GOVERNOR FORT}

Originated by Zvolanek, 1909 .

Donated by Zrolanck. Description in bricf - Salmon-pink self, hooded late.

Description in detail - Medium-sized flowers on long stems, nicely hooded. Color pale lilac-rose + ( $\mathrm{I}_{30}$ ). Moderately fragrant, late. Plant is strong grower but of medium height, with very dark green leaves. Comparison - Superior to Mrs. William Sim in color and fonn. Registered with the Society of American Florists as Governor John Franklin Fort, May, 1908.

\section{MRS. WILLIAM SIM}

Originated by Zrolanck, 1907 .

Donated by Zyolanek. Description in brief - Salmon-pink, hooded form, medium size, tall, vigorous grower. Late. 
Description in detail - Standard bright rose I ( 28 ), wings crushed strawberry I (I09) veined with Rose Neyron red I (I I9). Extremely hooded form, giving standard pointed appearance and reducing size. Stems long. Very vigorous, tall grower, over nine feet. Leaflets narrow and pointed. Stock true.

Comparison - Christmas-flowering Countess of Lathom.

Registered with the Society of American Florists, April, 1906.

\section{Crimson and Scarlet}

\section{RED SEEDLING}

Originated by Zvolanek.

Donated by Zvolanek.

Description in brief - Red, extremely hooded flowers, on long stems. A vigorous grower. Midseason.

Description in detail - Color of standard brighter than amarante red, or dull dark crimson 3-4 (I68); wings rosy magenta 2 ( 169 ), changing to magenta I ( $\left.\mathrm{I}_{2}\right)$. Flowers are of the extremely hooded form, appearing to be of only medium size due to pointed standard, which is not notched; wings large and spreading, showing the keel rather prominently. Midseason.

MRS. E. WILD

Originated by Zvolanek.

Donated by Zvolanek.

Description in brief - Carmine-pink. Very late.

Description in detail - Standard nearly crimson-carmine 4 (159), wings on outside I ( 59 ) but inside much lighter. Wings very large, long, broad, and spreading, exposing the keel, and often extending beyond margin of the standard. Fragrant. Very late. Stems large and strong.

Registered with the Society of American Florists, February, I9o6.

\section{Rose and Carmine}

\section{MIRS. J. F. HANNAN}

Originated by Zvolanek, I909.

Donated by Zvolanek.

Description in brief - Medium size, carmine-netted, hooded variety.

Description in detail - Color of standard Tyrian rose 2 (155); wings violet rose 3 (I54). In summer the color is solferino red I (I5i). Flowers on long, strong stems, fragrant, midseason, profuse bloomer. Plant a very strong, vigorous grower, making a dense, heavy growth, over nine feet. Leaflets narrow and pointed. Wings long, broad and concealing the keel.

Parentage - Seedling from Mrs. William Sim and Mrs. E. Wild. Synonym - Marian Hannan.

Registered with the Society of American Florists, April 21, I906. 


\section{MARIAN HANNAN}

Originated by Zrolanek, 1908.

Synonym-Mrs. J. F. Hannan, igog.

\section{PINK BEAUTY}

Originated by Zvolanck, I909.

Donated by Zvolanek.

Description in bricf — "Dark pink sclf." hooded, midseason.

Description in detail-Color of standard Tyrian rose 2 (155), wings violet rose 3 ( 154 ). Standard hooded, round, broad base; wings long, broad, hooded, and concealing the keel. Flowers on very long, strong stems. Productive. Fragrant. Plant very strong grower, above eight feet. Leaflets narrow, pointed.

Comparison - This year it does not differ from Mrs. J. F. Hannan. In

April, ig ro, the latter variety contained more of a salmon tint.

\section{PRAECOX CARMINE}

Originated by Engelmann.

Donated by Engelmann.

Description in brief - Carmine-netted, hooded, late variety.

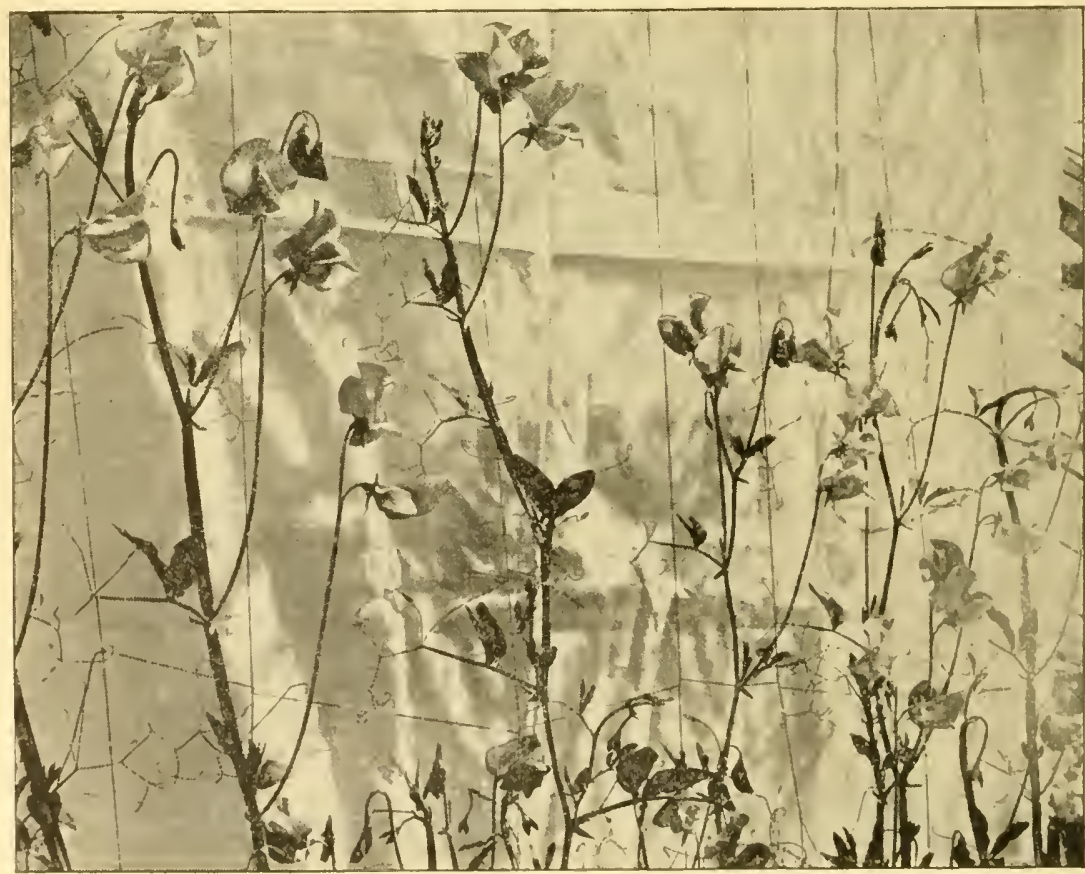

Fig. i76.-Praecox Carmine 
Description in detail - Color of standard crimson-carmine, 3 ( I59) on the front and 4 ( 159 ) on the back. Sometimes a solid color, sometimes the spaces between the netting are lighter. Wings are almost pure mauve 2 (180). With age the flower changes, the standard losing its crimson, becoming magenta, while the wings become a sickly purple hue. The standard is hooded and the wings are large and broad. The flower is medium to large, on long stems. Fragrant. Productive. Plant tall, vigorous grower.

Comparison - Distinctly a decper crimson than Mrs. Hannan or Pink Beauty.

\section{Lavender}

\section{CHRISTMAS COMTES}

Originated by Zvolanek.

Description in detail - When registered, described as "Clear lavender, average three flowers on a stem, plant five feet high, stems long. Improved Christmas and New Countess."

Comparison - "Lavender, similar to Countess of Radnor but much larger."- Florists' Exchange 22 (1906), p. 97.

Registered with the Society of American Florists, December, I90 I.

\section{TÉLEMLY MAUVE}

Originated by

Donated by Paul.

Description in brief - A light lavender, hooded variety.

Description in detail - Color of opening standard is bishop's violet I (I 89 ), changing to lobelia blue I (205); wings open bright violet 4 (I98), changing to ageratum blue I (20I).

Comparison - Similar to Countess of Radnor.

Remark - This variety is not of the winter-flowering type, but is an outdoor variety which when sown in September or October does not flower until April.

Originated by Engelmann.

\section{PRAECOX MAUVE}

Description in brief - Lavender, hooded, very late.

Description in detail - Color of flower heliotrope I (I88), changing to bright violet 2 (I98). Flower medium size. Plant vigorous and productive.

Comparison - Distinct from Mrs. C. H. Totty because it has very much less violet in the opening flower and becomes a truer lavender.

\section{MRS. CHARLES H. TOTTY}

Originated by Zvolanek, I907. Donated by Zvolanek. Description in brief - Lavender, hooded, midseason. 
Description in detail - Color of the opening standard is bright violet I (IDS), and wings ageratum bluc I (20I); changes to a light lavenderbluc, much lighter than I (204), and wings facle to Parma violet I (200), with white edges. In midsummer it is more heliotrope as it opens. Flowers hooded, occasionally with side notches. Stems long and strong. Fragrant. Plant a tall, vigorous grower, over nine feet. Comparison - A Christmas-flowering Lady Grisel Hamilton.

\section{Mauve}

\section{GREENBROOK}

Originated by Zrolanek, I908.

Donated by Zvolanck.

Description in bricf - Lavender blush on white ground.

Description in detail - Color, standard shaded in center with bright violet I (I9S) on white (2) ground; wings are white (2). Flowers slightly hooded, medium-sized on long stems; fragrant. Productive, carly.

Registered with the Society of American Florists, May, I908.

\section{PRAECOX DEEP MAUVE}

Originated by' Engelmann.

Donated by Engelmann. Description in brief - Decp maure, extremely hooded, very late.

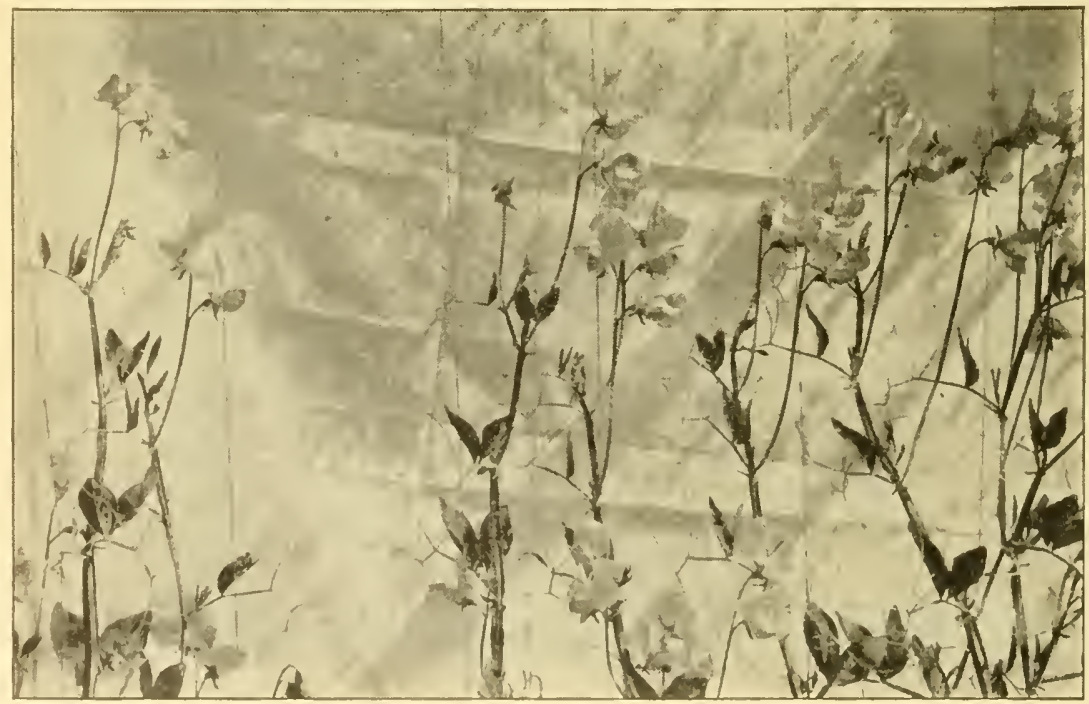

Fig. 177.-Praecox Decp Minme 
Description in detail - Color of standard is violet mauve I (195), changing to bright violet I ( 198 ) with edges bluish lilac I (I83); wings open heliotrope I-2 (I 88 ), becoming almost lobelia blue I (205). Flower extremely hooded, large-sized, on long stems. Plant tall, strong, vigorous grower, over nine feet; leaves broad and pointed.

Comparison - Distinct.

\section{MISS JOSIE REILLY}

Originated by Zvolanek, I907.

Donated by Zvolanek.

Description in brief - Lilac, with lavender wings.

Description in detail-Color of standard violet-rose I-2 (I 54), fading to pale lilac-rose I ( $\left.\mathrm{I}_{7} 8\right)$ with paler edges; wings lighter than ageratum blue I (200). Flower of open form, trace of notch at the top of the standard, wings long, broad, and concealing the keel. Flowers mediumsized, on moderately long stems, late. Plant is a moderate grower, under six feet.

Registered with the Society of American Florists, April 2I, I906.

\section{MRS. ALEXANDER WALLACE}

Originated by Zvolanek, I907.

Donated by $Z_{\text {volanek. }}$

Description in briff - Lavender, hooded, medium-sized flower, and a vigorous grower. Nidseason.

Description in detail - Standard opens bishop's violet I (IS9), changes

to ageratum blue I (20I). Wings open heliotrope I (I88) and change to Parma violet $+(200)$. Flower extremely hooded, making a pointed standard; wings hooded, concealing the keel. Fragrant. Free bloomer. Stcms long. Midseason.

Comparison - Same color as Wallacea.

Registered with the Society of American Florists, February, I906.

\section{WALLACEA}

Originated by Zvolanek, Ino9.

Donated by Zrolanek. Description in brief - Lavender, midseason. Comparison - This is a better strain of Mrs. Alexander Wallace.

\section{PRAECOX RIAROON}

(Lathyrus odoratus Praecox)

\section{Maroon}

Originated by Engelmann.

Donated by Engelmann. Description in detail - Color is not found in Répertoire de Couleurs, but that of the standard is nearest 4 ( $\mathrm{I}_{72}$ ), while wings are more purplish, being nearest 4 ( $\mathrm{I}_{5}$ ); keel shaded bishop's violet 4 (I89). Flowers of extremely hooded form, above medium size, on very long stems. Plant very vigorous grower, one of the tallest in the collection, over ten feet. 
Comparison - Distinct from Télemly Maroon.

Remark - Contained Praccox Carmine as at rogue.

\section{Violet or Purple}

\section{NIGER}

Originated by Zvolanek.

Donated by Zrolanek.

Lescription in brief - Deep, rich blue, hooded, medium size, and tall, vigorous grower. Midseason.

Description in detail - Color of standard rich pansy-violet 4 (191), wings bright violet-purple 3 (190), changing to violet-purple I (192). Standard without notch, wings short and broad. Flowers medium-sized, very slightly hooded, on very long stems. Productive. Plant tall, vigorous grower.

Comparison - Distinct from other blues.

Remark - Stock is mixed with MIrs. E. Wild.

\section{PRAECOX BLUE}

Originated by Engelmann.

Donated by Engelmann.

Description in brief - A blue-self, medium-sized, hooded variety.

Description in detail - See William J. Stewart.

Comparison - Similar to William J. Stewart.

\section{WILLIAIM J. STEWART}

Originated by Zvolanek, 190\%.

Donated by' Zvolanek.

Description in brief - Blue self, hooded, medium size. Productive. Early.

Description in detail - Color of the standard as it opens is a purpleviolet 2 (I92), changing to bluish violet 4 (I99); wings are brighter than 4 (190), changing to light bluish violet I (202). Standard somictimes notched on the sides, wings long, overlapping at tips, concealing the keel. Plant very vigorous, tall grower, ten feet.

Comparison - A Christmas-flowering Imperial Blue.

Registered with the Society of American Florists as Secretary William J. Stewart, March, I906.

\section{TÉLEMLY VIOLET}

Originated by Arkwright.

Donated by' Arkwright.

Description in brief - Blue self, medium size. Early.

Description in detail - Color of standard purple-violet 3 (192), changing to bluish violet + (199); wings light bluish violet + (202), changing to 1 (202). Standard hooded.

Comparison - Similar to Willian J. Stewart. 


\section{TÉLEMLY PURPLE}

Originated by Arkwright.

Donated by' Arkwright.

Description in brief - Purple, hooded, open-form, medium size, midseason.

Description in detail - Color of standard purple 4 ( $\left.18_{5}\right)$; wings bright violet-purple I (I90), changing to bluish violet. Flower with a round standard and long, broad wings. Fragrant. Stems long. Profuse bloomer. Plant tall, vigorous grower, over eight feet.

\section{Blue}

\section{BLUE BIRD}

Originated by Zvolanek, r 9 ro.

Donated by, Zvolanek.

Description in brief - A blue self, hooded, large. Early.

Description in detail - Color of the standard light bluish violet 3 (202). with lilac lower edges; wings light bluish violet, without trace of lilac. Flower often opens with considerable violet. Extremely hooded, largesized, on fairly long stems. Plant a moderate grower, over six feet. Registered with the Society of American Florists, May, I 908.

\section{LE MARQUIS}

Originated by Zvolanek, 1907 .

Donated by Zvolanek. Description in brief - Slightly hooded, indigo-blue color, medium size, strong grower. Midseason.

Description in detail - Color of standard violet purple 2 (192); wings light bluish violet $3(202)$. Slightly hooded, without notch. Flower medium-sized, on long stems. Plant a tall, strong grower, eight feet. Comparison - Télemly Indigo Blue is similar. Is Christmas-flowering Navy Blue.

Registered with the Society of American Florists, February, 1907.

\section{TÉLEVILY INDIGO BLUE}

Originated by Arkwright.

Donated by Arkwright. Description in brief - Slightly hooded, medium size, dark blue flower. Description in detail - Color of standard violet-purple I (I92) at the base, shading to 4 ( $\mathrm{Ig}^{2}$ ) at the edge; wings darker than light bluish violet 4 (202).

Comparison - Similar to Le Marquis.

\section{ZVOLANEK'S BLUE}

Originated by $\mathbf{Z}_{\text {volanek, i } 9 \text { Io. }}$

Donated by Zrolanek. Description in bricf - A large, hooded, clear blue flower. 
Description in detail - Color of standard light bluish violet $\mathrm{I}^{-2}$ (202); wings lavender-blue I (20.4); both veined with darker color. Flower large and hooded. Stem of medium length and strength. Fragrance moderate. Keeping quality very good. Plant of medium height and slender growth, and inclined to be a shy bloomer.

\section{ZVOLANEK'S ORANGE}

\section{Orange}

Originated by Zvolanck, i9 10.

Description in brief - A medium-sized salmon-pink flower.

Description in detail - Color of standard salmon-pink (I) г26; wings light lilac-purple i ( 60 ), flushed salmon-pink. The wings and standard veined with darker color. Flower medium-sized and hooded. Stem medium length and strength. Has little or no fragrance. A good keeper. Plant medium lieight, slender, and a moderate bloomer.

Comparison - "This can be represented as winter-flowering Miss Wilmott."-Zrolanck's Catalog, Io io.

\section{LIST OF ADDITIONAL, VARIE'TIES}

The following varicty names are found in swect pea lists or have been published:

Originated by

\section{ANGELINO}

Description in brief - "Self pink."- Vaughan's Book for Florists, July, 1910.

Comparison - This variety as scen at Mr. Sim's place is the variety Earliest of All.

\section{HELEN KELLER}

Originated by Zrolanek, I909.

Description in brief - "White and pink variegated."-Zvolanck's Catalog, 1909, p. 8 .

\section{MARION STANIFORD}

Originated by Zvolanek.

Description in brief - "Standard maroon, wings blue. Secdling from Christmas Captain x No. 93. Registered with the Society of American Florists, April 2 I, I906."

\section{SNOW QUEEN}

Originated by Zrolanek.

Introduced by Zvolanek, I909. Description in brief - "Pure white. Entirely new type of sweet peas. The shape is between Countess Spencer and Unwin types; flowers just as freely as Florence E. Denzer or Mrs. George Lewis. Black-secucd." - Zrolanck's Catalog, I909, 1). 8. 

LIBRARY OF CONGFESS

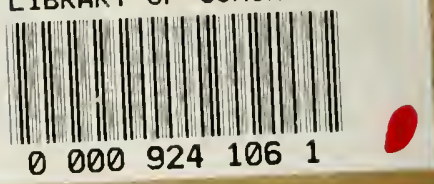

